Historic, Archive Document

Do not assume content reflects current scientific knowledge, policies, or practices. 



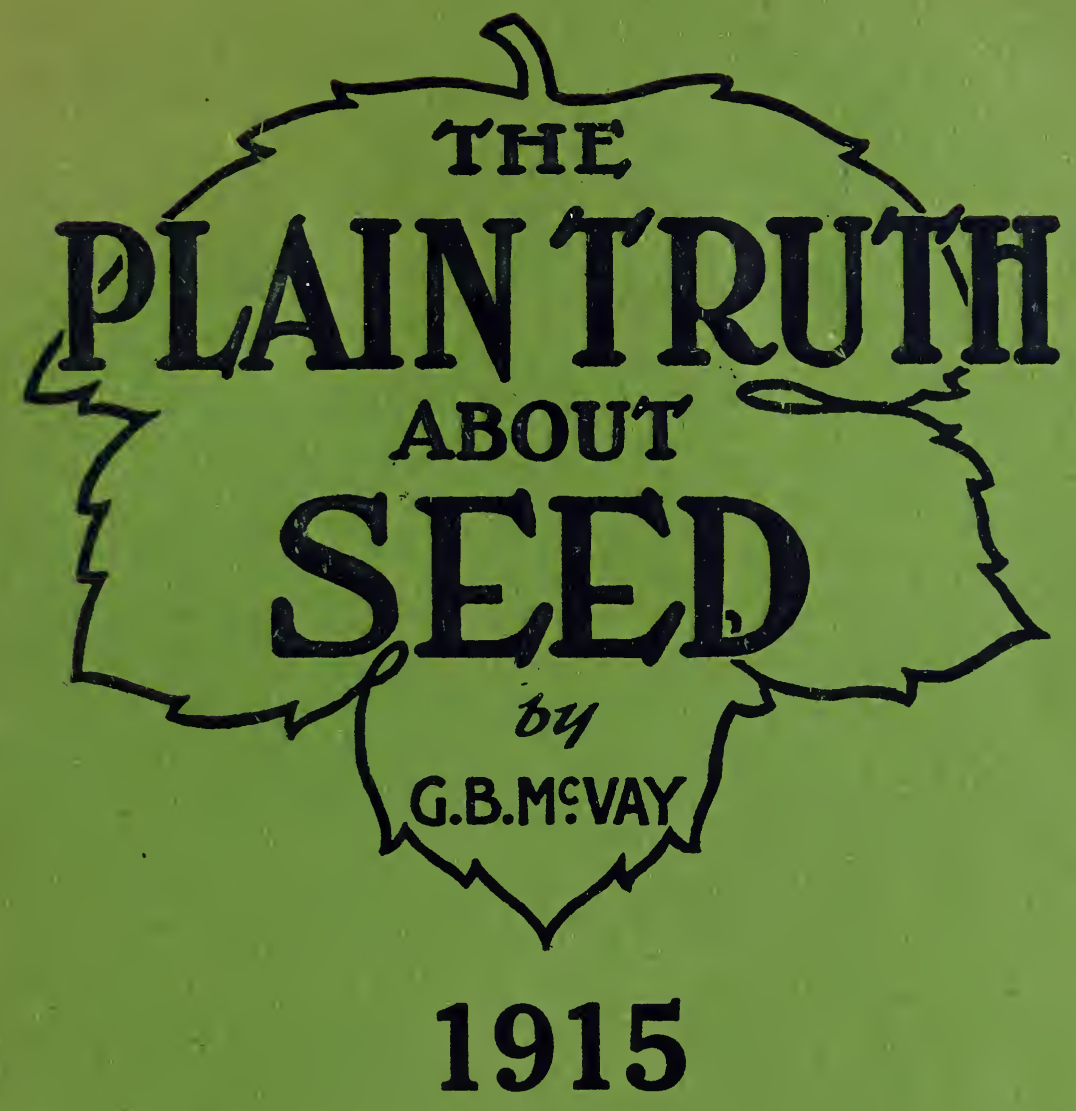

McVay Seed \& Floral Co. BIRMINGHAM

ALABAMA 


\section{General Directions for Ordering Seeds}

How to Send an Order-You will find on the opposite page an order sheet, perforated for tearing out, also a blank envelope to send order in, with our printed address on same. If convenient always use this order sheet, and avoid writing anything on order except what pertains to order. Questions, etc., requiring an answer by letter, should be written on a separate sheet, so it cannot be overlooked.

Terms-All orders to secure prompt attention should be accompanied with the cash. We would like to know everyone, but that is impossible. When remittance falls short it is our custom to modify quantity sent, instead of delaying order for letter.

C. O. D.-We would not advise anyone to order seed "C. O. D." We do not fill such orders unless enough money is sent to pay express both ways in case the goods are not taken out of office; besides, it is more expensive to purchaser. as he has to pay the express company for returning the money.

How to Send Money-If your office is a money order office remit by postoffice order. If your office is not a money order office, send your remittance by registered mail; or, if you have an express office, an express money order will do.

About Delivering Seed-It should be noted that our prices on all small seeds, including such items as Asparagus Seed, Beets, Cabbage, Carrots, Cauliflower, Celery, Collards, Cucumbers, Egg Plant, Lettuce, Cantaloupes, Watermelons. Mustard, Okra, Onion Seed, Parsley, Parsnips, Pepper, Pumpkins, Radishes, Spinach, Salsify, Squash, Tomato and Turnips, and any other small garden seed are delivered by mail, postpaid. or express at our expense. Now, when such items as these are ordered by express or freight, purchaser paying expenses, ten cents per pound may be deducted.

We do not deliver by mail or express such items as Beans. Seed Corn, English Peas, Grass Seeds, Potatoes or heavy field seeds of any kind; or sundries, like Poultry Supplies. Bug Poisons, Sorghums, Millets, etc., except a customer remits at the postpaid price as may be given in the catalogue. It will be noted that the last price quoted under each item of seed is the prepaid price, that is where we make a difference in the price by mail, postpaid, and the price where purchaser is to pay express or freight.

By Express-Orders too heavy for mails (five pounds and over), should be ordered by express when quick time is desired, and if no agent at your town the express will have to be prepaid by us, and you should include enough in your remittance to pay such charges.

By Freight - All heavy orders, such as Peas, Beans, Corn, Field Seeds, Onion Sets, Potatoes, etc. should be ordered sent by freight, and accurate shipping directions given.

\begin{tabular}{|c|c|c|}
\hline \multicolumn{3}{|c|}{ INDEX (Condensed for the Convenience of Customers) } \\
\hline $\begin{array}{r}1 \quad P a g e \\
\hdashline \quad 3\end{array}$ & Leek. & Page \\
\hline Asparagus. & Lettuce. & 19 \\
\hline Alfalfa.................. & Mangels, Stock Beets. & 10 \\
\hline $\begin{array}{l}\text { Beans, Green Podded, Bunch } \\
\text { Beans, Wax Podded }\end{array}$ & $\begin{array}{l}\text { Muskmelon, or Cantaloupe } \\
\text { Mustard.... }\end{array}$ & \\
\hline Beans, Pole...... 7 & Millets............-1. & 56 \\
\hline $\begin{array}{l}\text { eans, Lima_._._. } \\
\text { eets }\end{array}$ & Milo-Maize................... & 57 \\
\hline 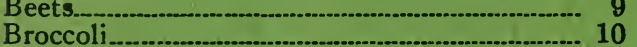 & $\begin{array}{l}\text { Miscellaneous Plants.. } \\
\text { Okra... }\end{array}$ & $\begin{array}{r}54 \\
23\end{array}$ \\
\hline Broom Corn. & Onions. & \\
\hline Brussel Sprouts................... & Oats... & 58 \\
\hline ar Weed. & Parsley. & \\
\hline Brooders.......... & Parsnips....--..- & \\
\hline Bug Death..... & Peas, English... & \\
\hline lbs. & Pepper & 28 \\
\hline .......... 60 & Potatoes.. & \\
\hline 11 to 12 & Pumpkins. & \\
\hline Canada Field Peas............... & Peanuts. & 51 \\
\hline Carrots....................... & Poultry Supplies....... & 74 \\
\hline auliflower & 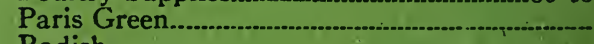 & 77 \\
\hline 14 & Radish & \\
\hline (n) & Rape, Dwarf Essex. & \\
\hline 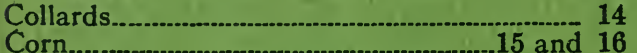 & $\begin{array}{l}\text { Rhubarb.-_-..- } \\
\text { Rice, Upland. }\end{array}$ & 54 \\
\hline ow Pea. & Rye. & 0 \\
\hline Clover Seed. & Salsify. & \\
\hline 61 and 62 & Sower & 3 \\
\hline 17 & $\mathrm{Sp}$ & 4 \\
\hline 18 & Spinach & 32 \\
\hline Dog and Animal Remedies........... & Sprayers._._. & 76 \\
\hline-18 & 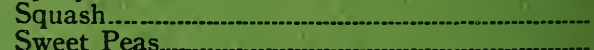 & $\begin{array}{l}33 \\
63\end{array}$ \\
\hline 37 & Swiss Chard. & \\
\hline Flower Seeds......... & Soja, or Soy Beans.............. & 18 \\
\hline -....... 41 & Slug Shot & 77 \\
\hline - & Sorghun & 55 \\
\hline Mixtures & Tomatoes... & 35 \\
\hline 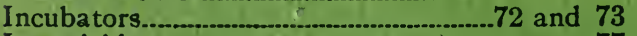 & Turnips. & 36 \\
\hline Insecticides._. 77 & Teosinte & 56 \\
\hline Introduction & Tools and Implements & $\begin{array}{l}80 \\
40\end{array}$ \\
\hline (n) & $\begin{array}{l}\text { Vetches.... } \\
\text { Velvet Bea }\end{array}$ & U \\
\hline $\begin{array}{l}\text { le } \\
\text { hl-Rabbi }-18\end{array}-18$ & 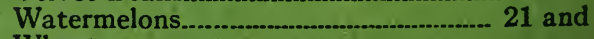 & \\
\hline hl-Rabbi______L & Wheat__ & \\
\hline
\end{tabular}




\section{McVay Seed \& Floral Company BIRMINGHAM, ALABAMA}

\section{PLEASE FILL IN THESE BLANKS PLAINLY}

Ship Articles on this Sheet as Specified.

Name...

Postoffice R. F. D. No.

County

State

State Shipping Point if Different from Postoffice.
Amount Enclosed.

Postoffice Order.

Stamps.

Express Money Order.

Check

Date.

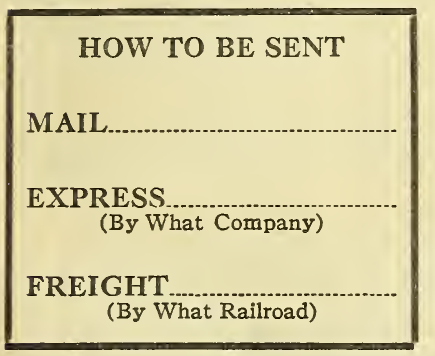

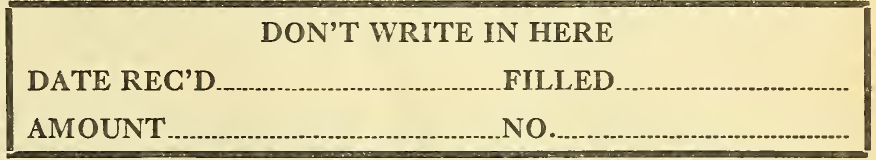

ABOUT DELIVERED PRICES-All small garden seed are delivered by us at prices in Catalogue, so when you order these with heavy stuff to come by express or freight deduct 10 cents per pound. Beans, peas, corn, farm seed and other heavy stuff require extra remittance for postage at the rate of 10 cents per pint or pound, and 15 cents per quart; that is, where no special price is quoted by mail postpaid.

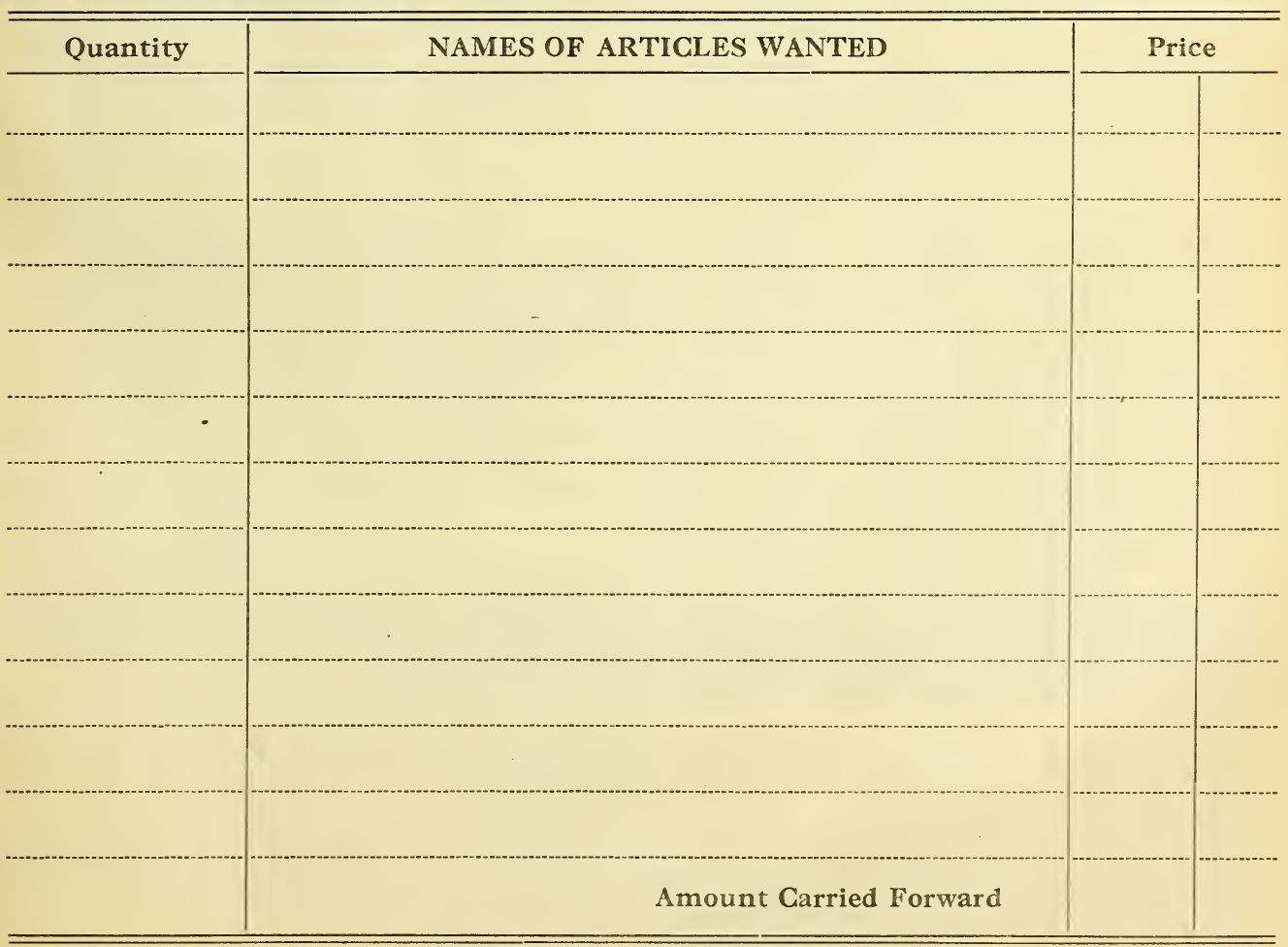




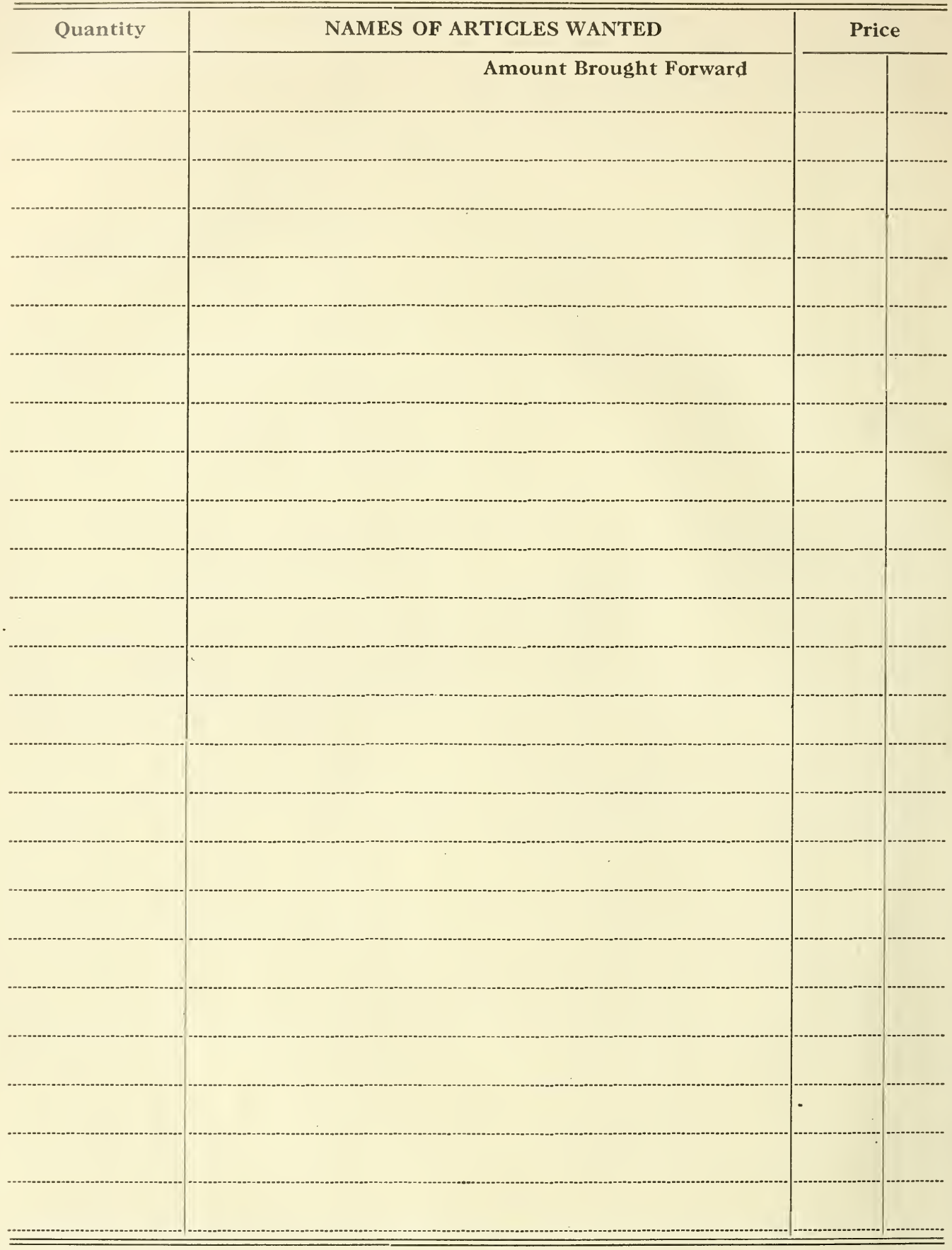

Write all you want to say about this order on this sheet. Requests for quotations and other information requiring an answer on separate piece of paper.

Send us here the name and address of two or three parties who plant a good lot of seed: Name. P. O. Address.

Name.

P. O. Address.

Name.

P. O. Address.

Messrs. McVay Seed \& Floral Co. gives no warranty, express or implied, as to description, quality, productiveness, or any other matter of any Seeds, Bulbs or Plants they sell, and they will not be in any way responsible for the crop. If the purchaser does not accept the goods on these terms they are at once to be returned, and money, if any that has been paid, will be refunded. 
CATALOGUE-1915

\title{
The Plain Truth About Seed
}

\author{
By G. B. McVA Y \\ Published by
}

\section{McVay Seed E Floral Company \\ BIRMINGHAM, ALA.}

\section{INTRODUCTORY}

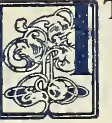

T IS THE PURPOSE OF THIS CATALOGUE to give "The Plain Truth About Seed" in so far as the writer's ability goes and the space that can be allotted, within its confines, to each subject.

It will not be confined altogether to Seed Subjects, but will describe a great deal of other merchandise that most every Farmer, Truck Grower or Poultryman, will be interested in. The modern seed house is somewhat of a department store for farm supplies of a varied nature, and a careful reading of the within catalogue will show a very comprehensive line of useful articles besides seeds.

The writer of this catalogue has written twenty-nine seed catalogues in the last twenty years, and feels competent of constructing good, plain readable information that ought to be of value to those interested.

\section{SOME THINGS WE HANDLE}

Garden Seed-You will find in this catalogue a great many varieties eliminated-some old and well-known-but we have determined to throw out such sorts; where new and improved varieties have shown greater merit.

For example, there is no sense in catalogueing twenty or more varieties of watermelons when a half dozen will cover the choicest sorts. In short, we are not going to give space to varieties of seed that we know to be worthless in comparison to those that we do list.

Grass Seed-The great drawback to a much larger use of grass seed, especially in the South, is due to worthless quality and the fraud practiced in manipulating the seed. The farmer is often to blame, because he generally buys the cheapest he can get. It is pure nonsense to try to economize in seed buying. or none.

We are going to endeavor to set a higher standard in grass seed for the South-will sell good stuff,

Forage Plants-This is getting to be an important factor in farm management, because a great many of such plants are legumes, that is fertilizing or soil renovating plants and these have special attention in this catalogue. The list includes Peanuts, Cow Peas, Soy Beans, Velvet Beans, Canada Field Peas, Vetches, Beggar Weed. We also handle a large miscellaneous list of forage plants, including such valuable plants as Sorghum, Millets, Kaffir Corn, Milo Maize, Teosinte, Speltz, etc.

Fertilizers-We handle a complete line of high grade fertilizers, including fertilizer material such as Kainit, Muriate of Potash, Sulphate of Potash, Nitrate of Soda, Sulphate of Ammonia, Acid Phosphate, Dried Blood, etc. We are in position to furnish these ingredients in any quantity from five cents' worth to a car load. We are also prepared to write special formulas for any of our customers demanding a special mixture for certain crops and adapted to different soils. We invite you to consult us freely on this subject.

Poultry Supplies-We invite your attention to our extensive line embracing practically everything for the poultry man. The line is so comprehensive it should be looked over in detail.

Insecticides-Bug insurance is getting to be appreciated by the public, and it comes cheap through the medium of modern appliances and suitable remedies, which we handle largely.

Sprayers-We handle a large line of these, from twenty-five cents up, and no family should be without a sprayer for some purpose.

Seed Grain-We handle such seed grain that we know to be adapted to the South; in fact, especially grown for the Southern farmer. We invite your attention to our list. best.

Cotton Seed-Our list is not as long as some others, but we know what we handle to be the

We appreciate your business.

Respectfully,

McVAY SEED \& FLORAL CO.,

Birmingham, Ala. 


\section{Monthly Calendar of Operations for the Southern Farmer}

We are so often asked the question when and what to plant at certain periods, that we have thought it advisable to put a Calendar in print that would be available to any one possessing our catalogue.

Caution.-This Calendar is made for the latitude of Birmingham, so if you are farther south, you should plant earlier and, of course, later if farther north.

\section{JANUARY}

Plant Onion Sets, Irish Potatoes, English Peas, Mustard Turnip, Spinach, Carrots, Beets, Radish, Asparagus, Seed Oats, Canada Field Peas, and any of the hardy grasses, clovers, pasture and lawn grasses. In cold frames or hot beds any of the more tender vegetables may be sown. In flower seed, Sweet Peas should be planted in the open. In cold frames, hot beds and even boxes protected, Poppies, Hollyhock, Pansies, Daisy, Verbena and Aster. All sorts of Roses, Shrubbery, Fruit Trees and Shade Trees.

\section{FEBRUARY}

The same items mentioned for January may be planted this month, only a much greater variety, providing of course the season appears to be early. This is the most active month with the Trucker. Early Corn, Irish Potatoes, English Peas, Onions, Radish, Salsify, Mustard, Turnip, Spinach, Kale, Carrots, Beets, Lettuce, Tomato, Parsnips, Cabbage, Tomato, Collards, Kohl Rabi, Leek, Lettuce.

In field crops, Oats, practically all the grasses and hardy forage plants. Most all flower seed and spring bulbs may be planted.

\section{MARGH}

This is the most active month generally with the home gardener and farmer. Much, of course, depending on the season. Every one must exercise some discretion. Potatoes may still be planted and Sweet Potatoes bedded. The latter part of March, all the tender vegetables may be planted outdoors. This is the main month for planting flower seed. All forage plants may be now safely planted.

\section{APRIL}

A popular month with the home gardener. All tender stuff may now be planted with perfect safety. Flower Seed of every description may be planted. Forage crops, such as Sorghum, Millets, Peanuts, Chufas, Soy Beans, Cow Peas, Kaffir Corn, etc., should be gotten in for early use. Field Corn, Cotton and Velvet Beans may be planted.

\section{MAY}

This month is a good time to plant Melons, Squash, Cucumbers and Sweet Potato plants. Grasses and Forage Plants may still be planted. All vegetables may be planted for a succession of those early plantings that have given out.

\section{JUNE}

Plant Corn for late crops; Pole Beans, Lima Beans, Ruta Baga, Melons, Pumpkins, Squash; sow Cow Peas, Soy Beans, Velvet Beans, Sorghums and Millets.

\section{JULY}

Sow Ruta Baga Turnips, Tomatoes, Lettuce, Radish and Cabbage for late crops; plant Cow Peas, Soy Beans, Peanuts, Sorghum, Millets and other Forage Plants.

\section{AUGUST}

Prepare for fall garden because this month and the next is the proper time to plant most all small garden seed for a second crop. Don't let the garden run out; keep on planting.

\section{SEPTEMBER}

This is an active month to make successions of plantings of most everything. Begin to sow Rye, Barley, Oats, Clovers and Grasses for early pasture.

\section{OCTOBER}

Put out Cabbage and Collard Plants; sow Winter Turnips. Don't overlook sowing Clovers and Grasses to afford winter pasture.

\section{NOVEMBER} Peas.

Sow Rape, Wheat, Oats, Rye, Barley, Vetches, Canada Peas. Be sure and gather your Cow

\section{DECEMBER}

Sow in cold frame, hot beds or boxes, Cabbage, Cauliflower, Pepper and Egg Plant for early plants, Prepare your land for spring crop. 


\section{Artichoke (Jerusalem) from Roots}

How to Grow-This variety of Artichoke may be grown in the same manner as potatoes, only it is probably desirable to make rows three and a half to four feet apart and plant eighteen inches to two feet apart in row. The same class of soil and culture for potatoes will answer. The small tubers may be planted whole, but they may be cut up like potatoes. When properly cut eight to ten bushels is sufficient to plant an acre. The plants do not mature before early fall, and may be destroyed by plowing up in June or July. The proper time to plant is from December to March, the earlier the better. If you wait till the weather gets warm you can't buy the seed because they won't keep.

The Best Fertilizer-The same fertilizer and quantity used on potatoes should be sufficient for Artichokes. They delight in rich, loamy soil.

Jerusalem Artichoke-This variety of Artichoke is grown for its roots, which resemble potatoes somewhat. The plants yield an enormous amount of tubers, often as many as five and six hundred bushels to the acre. As a food for hogs, it surpasses most any other root crop. They can be left in the soil for hogs to harvest or they can be put away for winter use the same as sweet potatoes. Bushel, $\$ 1.75$.

French Variety (From Seed) - This variety of Artichoke is altogether different from the tuberous variety known as Jerusalem Artichoke. The French variety is grown for its edible flower buds, which are prepared for eating very much the same as asparagus. This vegetable does well in the South, and deserves to be more largely cultivated. Pkt., 5c; oz., 35c; $1 / 4$ lb., $\$ 1.00 ; 1 b ., \$ 3.50$.

\section{Asparagus}

We don't advise any one to bother with Asparagus seed except the professional trucker who wants to produce on a large scale. The roots can be had cheap, and from their use you can have Asparagus right away, and avoid waiting two years to obtain from seed. No vegetable is more wholesome and healthier than Asparagus, and it is certainly a wonder that every private garden does not have a bed of it.

How to Transplant-Select a place where the soil is very light and rich and open up deep furrows, say about eight inches deep and four or six feet a part. The roots are to be placed in the bottom of the furrow, about eighteen or twenty-four inches apart, and covered with only two or three inches of soil, but as the shoots appear fill in around them with well rotted stable manure. You must keep the weeds and grass off the beds and not cut any of the shoots until the bed is about a year old. The beds should have a good dressing of stable manure in November or December each year. It is a good idea to plow around the beds in the fall and fill the furrow with rich manure; cut down the old stalks and throw dirt back over the old bed. Cut only the green shoots for the table and never too far under the ground. Two year old roots are generally preferred, although one year old roots are really better if properly grown. The best time to plant or put out roots in the South is during November and December, although it is permissible and often just as well to plant out in January, February and March. Two year old plants will produce considerable Asparagus when planted in the fall within fifteen months and decidedly more every year thereafter. It is generally advisable to let the plants go to full maturity once before any Asparagus is ever harvested. One hundred of two year old roots is generally used to a bed say fifteen by forty feet. Five to seven thousand are generally provided for an acre. This depends of course on method of planting, distance of rows, etc.

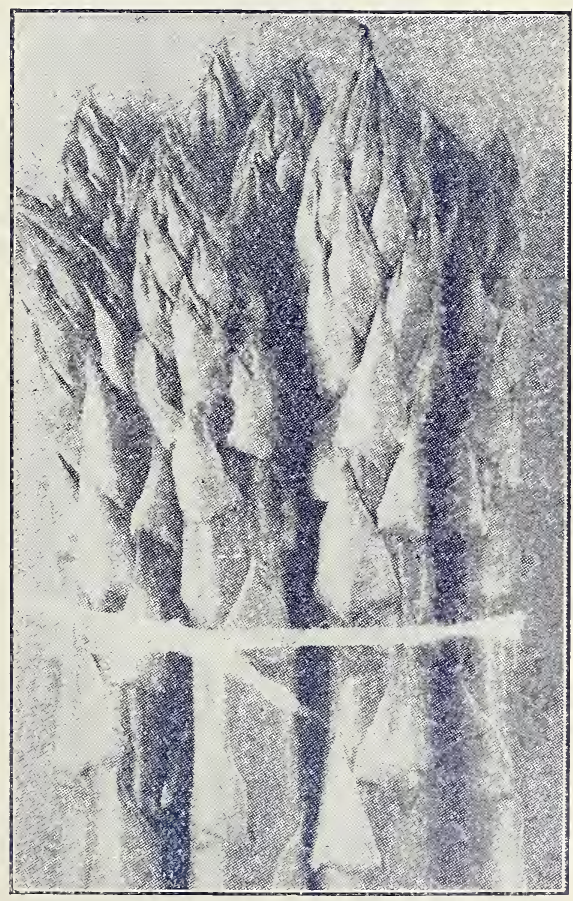

Price of Asparagus Roots-By mail, postpaid, doz., 25c. By express or freight, per 100, 75c; per thousand, \$6.00. Special price in large quantities. October to March.

Asparagus Seed-Seed may be planted in rows in early spring, and allowed to mature plants. The roots from these plants can be taken up and set out in early spring year following. Directions should be followed as above under how to transplant.

Conover's Colossal-In our experience this is the most reliable sort, stalks being very large and thrifty. Pkt., 5c; oz., 10c; $1 / 4$ lb., 25c; lb., $75 \mathrm{c}$.

Palmetto-A very large and prolific sort, of good quality. Pkt., 5c; oz., 10c; 1/4 lb., 25c; lb., 75c 


\section{Beans, Dwarf Green Podded}

The 1913 and 1914 crops of Bunch Beans was very short. Prices will be high. We don't guarantee our prices - which are subject to change without notice.

Time to Plant-Beans may be planted in most sections of Alabama from February to September $15 \mathrm{th}$, depending, of course, on the nature of the season, weather conditions, etc. In favorable weather it only requires forty-five to sixty days for beans to commence to bear. They should be planted in succession at intervals from February to September.

How to Grow-Since Beans are leguminous plants it is popularly supposed that they do not require rich soil, but it will always be found that a rich friable loam will give best results with Beans. Most any soil, however, can be made to produce good beans, if fertilized properly. Beans suffer very easily from drought, so it is profitable to make thorough preparation and cultivate often. Pods should be harvested as fast as large enough for eating. A pint is sufficient to plant from sixty to seventyfive feet of drill, depending some on the size of the bean; one bushel is sufficient to plant an acre where cultivation is to be done by horse, but where hand cultivation is to be used they may be planted closer, and require a bushel and a half to the acre.

The Best Fertilizer-Any high grade complete fertilizer will do for beans, but the most essential element seems to be phosphoric acid and potash. From four hundred to one thousand pounds of high grade complete fertilizer should be used on an acre, depending, of course, on the natural fertility of the soil.

Bacteria, Inoculation-Large yields of Beans may be secured through inoculating your seed with nitrogen-gathering bacteria. It is very inexpensive, and often increases the yield four to five times. Write for pamphlet on the subject. Price of Bacteria, by mail, postpaid, trial package, 50c; one acre package, $\$ 2.00$. Full directions in each package how to proceed.

Notice our post paid prices-Express is usually cheaper on 4 pounds or more.

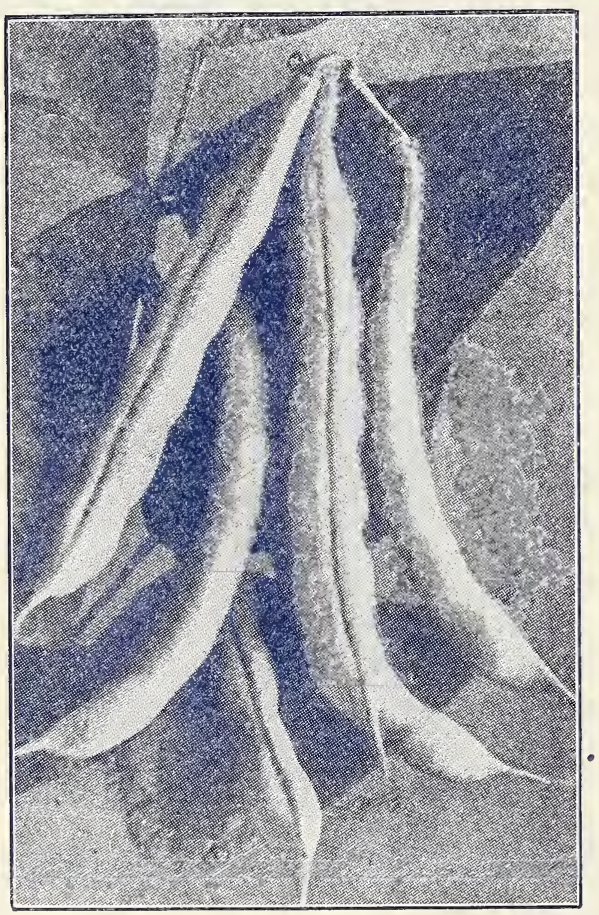

HOPKINS IMPROVED VALENTINE

Hopkins' Improved Valentine-For an absolute certainty in Green Podded Bunch Beans nothing is equal to the Valentine for the South. The Hopkins strain of Valentine is superior for market purposes to the ordinary Valentine because it is a more vigorous grower and larger yielder, and the pods, while no better, are considerably larger, longer, round and not quite so curved. The dry Bean is a large, long, deep red speckled one, being considerably different to the ordinary Valentine in appearance It stands the dry, hot weather at the South better than any sort of the same quality. This is the variety exclusively planted by truckers in Alabama who grow largely for shipment to Northern markets.

Gaution-This is a different type of Valentine Bean from what is ordinarily sold. This stock will always come true round podded. We make a specialty of the true Canadian grown sealed stock and supply it to the planter direct. You will not be disappointed if you secure your seed from us. Price: Pt., 20c; qt., 35c; pk., $\$ 1.75$; bu., $\$ 6.50$. By mail, postpaid, pt., 30c; qt., 50c.

Early Red Valentine - This is the standard early round, green podded bunch Snap Bean. It is the hardiest variety known of first-class quality. It is extremely hardy, standing more hot dry and cold weather than any other sort. The variety is exceedingly prolific, and bears fruit longer without dying out than any other sort. No one is ever disappointed in planting the Early Red Valentine. Pt., 20c; qt., 35c; pk., $\$ 1.75$; bu., $\$ 6.50$. By mail, postpaid, pt., 30c; qt., 50c.

POULTRY SUPPLIES-Do you raise poultry? Read Pages 71 to 76 . You will find many things of interest. 
Burpee's Stringless Green PodThe dry Bean of this variety is large, brown and oblong in shape. The green pod is almost straight, from four and a half to five inches long, is perfectly stringless, broad and very meaty. It is just as early as the earliest type of Valentine. Vines more vigorous and the pods more uniform in size. If seasons are favorable it will out-yield the Valentine, and the quality is undoubtedly superior. We can recommend this Bean as being a first-class, stringless, green podded sort. Pt., 20c; qt., 35c; pk., $\$ 2.00$; bu., $\$ 7.50$. $1 \mathrm{By}$ mail, postpaid, pt., 30c; qt., $50 \mathrm{c}$.

Giant Stringless Green Pod-This variety is also known as the Giant Stringless Valentine. The dry Bean is a yellowish brown, very much the shape of the Valentine. The vine is a vigorous grower, very prolific, early, pods almost the same as Valentine, only much longer and not so curved. The quality is not excelled by any sort, as the pod at all stages is entirely string-. less. Pt., 20c; qt., 35c; pk., $\$ 2.00$; bu., \$7.50. By mail, postpaid, pt., 30c; qt., $50 \mathrm{c}$.

Longfellow-The dry Bean resembles a red speckled Valentine only a little slimmer and more of a brownish color. The pod is perfectly round, longer and larger than Valentine, averaging $51 / 2$ to $61 / 2$ inches long. It is just as early and less strings. The color is a beautiful green of handsome appearance and a good shipper. The variety is very resistant to hot weather, bearing its fruit in great clusters. Pt., 20c; qt., 35c; pk., $\$ 1.75 ;$ bu., $\$ 6.50$. By mail, postpaid, pt. 30c; qt., 50c.

Black Valentine-The growth of this variety is almost identical with the red speckled Valentine, only the seeds are black. It is hardier than other Valentines, more vigorous in growth and a larger yielder. It is extremely prolific and its bearing period longer than most bunch sorts. Pt., 20; qt., 35c; pk., $\$ 2.00$. By mail, postpaid, pt., 30c; qt., 50c.

Refugee, or One Thousand to One-A very hardy, vigorous, late growing sort. Pods long green, practically round, and of excellent quality. This variety has a small leaf, vines spreading in character, and very resistant to cold and dry weather. It is largely planted in the South in the fall of the year. Pt., 20c; qt., 35c; pk., $\$ 1.75$; bu., $\$ 6.50$. By mail, postpaid, pt., 30c; qt., 50c.

Extra Early Refugee-A very robust-growing early green podded sort. The pod is five to five and one-half inches long, half round, fleshy, and very fine snap. This vareity is very resistant to both cold and heat. Seed are small and brown speckled. Pt., 20c; qt., 35c; pk., \$1.75; bu., $\$ 6.50$. By mail, postpaid, pt., 30c; qt., 50c.

Dwarf White Navy-A very prolific variety of white shell Bean. Vines grow robust, sometimes throwing out short runners and spreading. Pods straight, short, small, but usually contain six beans. The variety is very prolific, and farmers of the South will find them profitable to grow for market or home use as a shelled Bean. Pt., $15 \mathrm{c} ;$ qt., $25 \mathrm{c} ;$ pk., $\$ 1.75 ;$ bu., $\$ 6.00$.

\section{ABOUT PRICES FOR BEANS}

It is quite impossible when this catalogue is written to quote satisfactory prices on Beans. The price by the pint and quart is very near correct, but truckers who want to purchase in large quantities should write for special prices, stating quantity. 


\section{Wax Podded Beans}

\section{(DWARF)}

Wardell's Kidney Wax-This is the most popular variety in Florida and throughout the South for growing for shipping to Northern markets. The seed is white with dashes of light purple, and shaped like a kidney. The pod is very long, flat and broad. When cooked, is almost transparent,

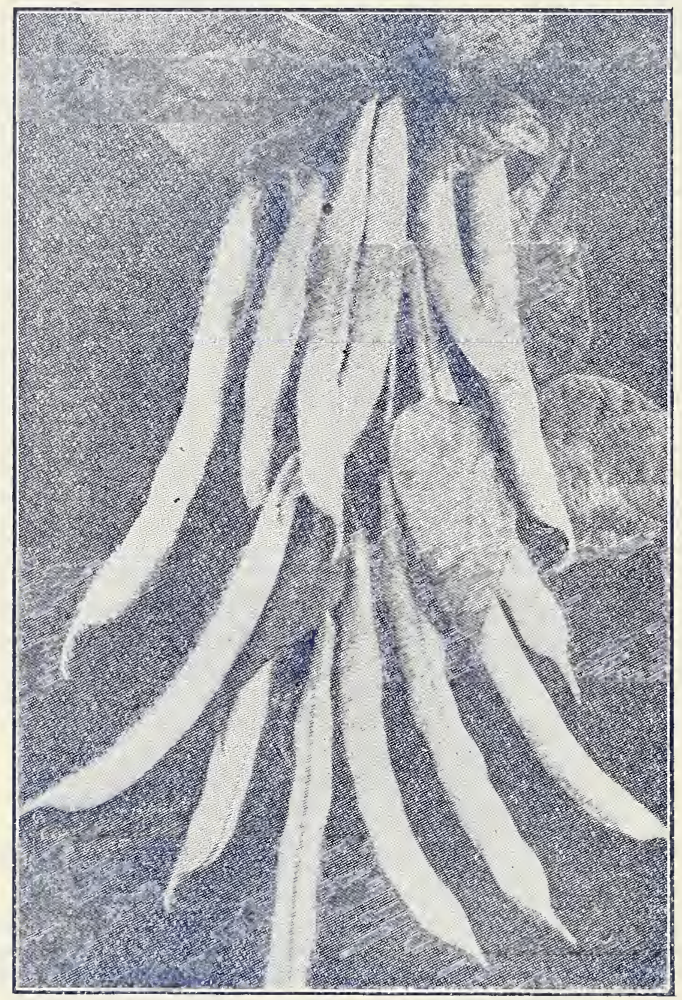

TYPE WAX BEAN very tender and void of tough strings. On good soil, the growth is very rank, and should be given extra distance. It is a splendid yielder, and ought to turn out a hundred to one hundred and fifty bushels pods to the acre. Pt., 20c; qt., 35c; pk., $\$ 2.00$. By mail, postpaid, pt., 30c; qt., 50c.

Davis Wax-The seeds of this sort are pure white and kidney shaped. It is very popular in the South for market purposes, because being of the hardiest type of Wax Bean, can be planted earlier than other sorts. The pods are long, almost white, straight, and rarely, if ever, affected with rust spots. A splendid shipper; fills up the bean crate very fast. Pt., 20c; qt., 35c; pk., $\$ 2.00$. By mail, postpaid, pt. 30c; qt. 50c.

Keeney's Rustless Golden Wax-The dry bean is white, speckled with dashes of reddish brown. The variety is a vigorous grower, and seems to be a runner when it starts off, but such branches become selfsupporting and bear enormously. The pod is large, of light, golden pale yellow and entirely stringless. In quality this variety is one of the best wax sorts. It is very desirable for home use or for market. Pt., 20c; qt., 35c; pk., $\$ 2.00$. By mail. postpaid, pt., 30c; qt., 50c.

Currie's Rust Proof Wax-This variety is more resistant to rust and other diseases affecting this type of Beans than any other wax sort. The dry Bean is large, long and of a bluish black. The pods are long, broad, flat. straight, and of rich golden yellow color. The vine is very hardy and robust in growth, holding the pods well above ground. The quality is splendid. Pt., 20c; qt., 35c; pk., \$2.00. By mail, postpaid, pt., 30c; qt., 50c.

Challenge Black Wax-Usually known as the Black Wax, is one of the earliest as well as one of the most prolific varieties grown. It will bear thicker planting than any of the Dwarf Wax soris. The pods are almost round, transparent, and entirely stringless; very crisp and of delicious flavor. Pt., 20c; qt., 35c; pk., $\$ 2.00$. By mail, postpaid, pt., 30c; qt., 50c.

Hodson Wax-Bean is speckled, about the same size and looks like Valentine. Extremely early, very prolific, pods long, flat, very fleshy and perfectly stringless. The vine is a vigorous grower, literally hung with yellow creamy pods. Pt., 20c; qt., 35c; pk., \$2.00. By mail, postpaid, pt., 30c; qt., 50c.

FORAGE PLANTS-If you are interested, read section of this catalogue devoted to them and write us your wants, and let us quote you special prices on definite quantities. These items fluctuate, making it impossible to quote accurate figures when this book is written. 


\section{Pole Beans}

How to Grow-Pole Beans ought to be planted in rich soil and thinned out promptly to eighteen to twenty-four inches apart. Stakes or some support for them to run on ought to be provided before they begin to run. They may be planted any time from March to September.

It is well known that the quality of tender varieties of Pole Beans is far superior to that of the bunch or dwarf sorts, and they would be more largely grown but for the trouble of supplying supports. The flavor is superior and every gardener should make an effort to grow them. And again some varieties are just about as early; notably, the Tennessee Wonder and the Texas Pole or Kentucky Wonder.

Tennessee Wonder (Scotia, Cornfield, Striped Creaseback, etc.)-This bean as well as many others, is sold under and known in different localities by various names. It is not a new sort, but it seems that the seed trade has only took it up in past few years. The seed are medium size, slightly flat oval and curve in to the eye, forming a kidney shape. The seed in color is gray, flecked with dark spots and some distinct black stripes. It is the earliest Pole Bean grown, often maturing pods in fifty five-days. It bears in clusters immense long curved and twisted pods which are practically stringless, tender, and of delicious flavor. It should have tall supports, and does well in corn. Pt., 20c; qt., 35c; pk., \$2.00; bu. \$7.50. By mail, postpaid, pt., 30c; qt., 50c.

Texas Pole Bean (Known also as Kentucky Wonder, Old Homestead, and Mammoth Podded Southern Prolific) -We reproduce here an actual photograph of the Texas Pole Bean, showing the enormous clusters the variety produces. This photograph has been reduced to one-third of the actual size of the green pods, so you can easily figure the size of the specimen photographed by multiplying the dimensions shown in the picture by three. Now, besides being the largest Pole Bean in cultivation, it is far superior to most any other sort in eating qualities. The dry bean is long, of a yellowish brown color, and has a distinct pinkish eye, with white center. It is a hardy germinator, vines grow off rapidly, become rank, and would reach the height of twenty or more feet if provided with such support. "The vine commences to bear in about sixty to seventy-five days after seed is planted. The pods, when they first appear, are very long and exceedingly slender, grow rapidly to the length of ten to fifteen inches, and after reaching its length the pod fleshens up and becomes very meaty, solid and large in circumference. The pods are round, of beautiful green color, practically stringless, remain in eating condition a long time, and cannot be surpassed for flavor. Pt., 20c; qt., 35c; pk., $\$ 2.00$; bu., $\$ 7.50$. By mail, postpaid, pt., 30c; qt., 50c.

Crease Back or Fat Horse-A very early and prolific Pole Bean. The dry bean is small, white, resembling a small white navy, only more kidney shaped. The green pods are of good length, borne in clusters, stringless, and of the very best quality. Pt., 20c; qt., $35 \mathrm{c}$; pk., $\$ 2.00$; bu., $\$ 7.50$. By mail, postpaid, pt., 30c; qt., $50 \mathrm{c}$.

White Dutch Case-Knife (Cornfield Bean)-A large, white, flat bean, resembling the "old-fashioned" butter bean very much, only is much larger. The pods are long, green, tender, flat and are borne in great clusters. Pt., 20c; qt., 35c; pk., \$1.75; bu., \$6.50.

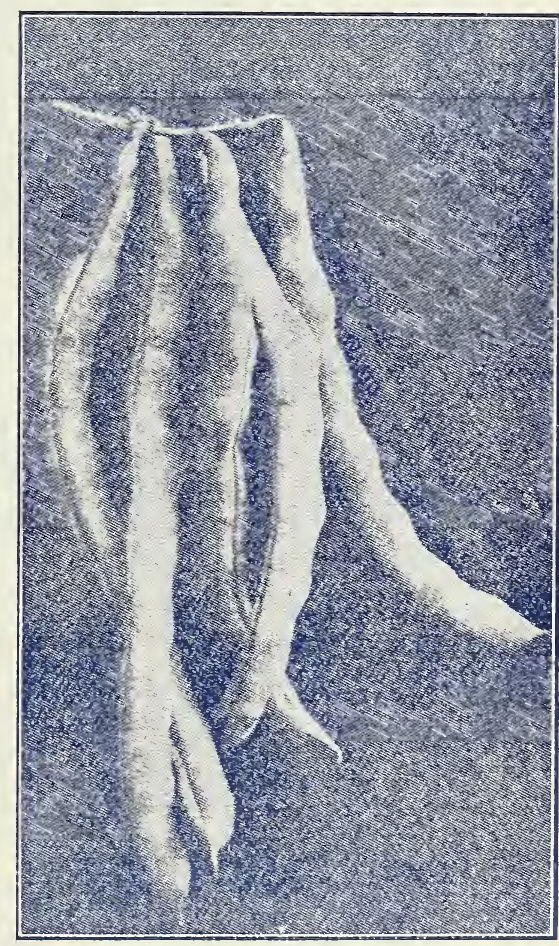

TEXAS POLE BEAN

By mail, postpaid, pt., 30c; qt., 50c. for for planting in corn. Pods short, thick, tender when young, and exceptionally good shelled. Pt., 20c; qt., 35c; pk., $\$ 1.75$; bu., $\$ 6.50$. By mail, postpaid, pt., 30c; qt., 50c.

Horticultural, or Wren's Egg (Sometimes called the October Bean, Cornfield Bean, etc.) -The pods are green with dashes of red, and mature in about seventy-five or eighty days. It is very hardy and enormously productive, making very large and luxuriant vines and yielding pods about six inches in length. The appearance of the bean when dry is large, almost round, plump, speckled, and resembles a wren's egg, hence its name. The pods when not too old are very tender and the shelled beans are unsurpassed. Pt., 20c; qt., 35c; pk., $\$ 1.75$; bu., \$6.50. By mail, postpaid, pt., 30c; qt., 50c.

Southern Prolific-Pods long, green, very fleshy and tender when not too old, but if allowed to remain on vine too long get tough and stringy. Pt., 20c; qt., 35c; pk., $\$ 1.75 ;$ bu., $\$ 6.50$. By mail, postpaid, pt., 30c; qt., $50 \mathrm{c}$.

Lazy Wife's-Producing tender pods from four to six inches in length, of dark green color, which it retains until amlost ripe. The bean is white and almost round and is fine for baking in winter, as its exceedingly luscious flavor is not surpassed by any bean. Pt., 20c; qt., 35c; pk., $\$ 2.00 ;$ bu., $\$ 7.50$. By mail, postpaid, pt., 30c; qt., 50c. 


\section{Lima or Butter Beans}

How to Grow-Butter Beans may be grown in the same manner as you would ordinary String Beans. The greatest trouble experienced in growing this class of beans lies in the fact that so few varieties in the South seem to be a success. The larger varieties, both bunch and pole, do not seem to stand the

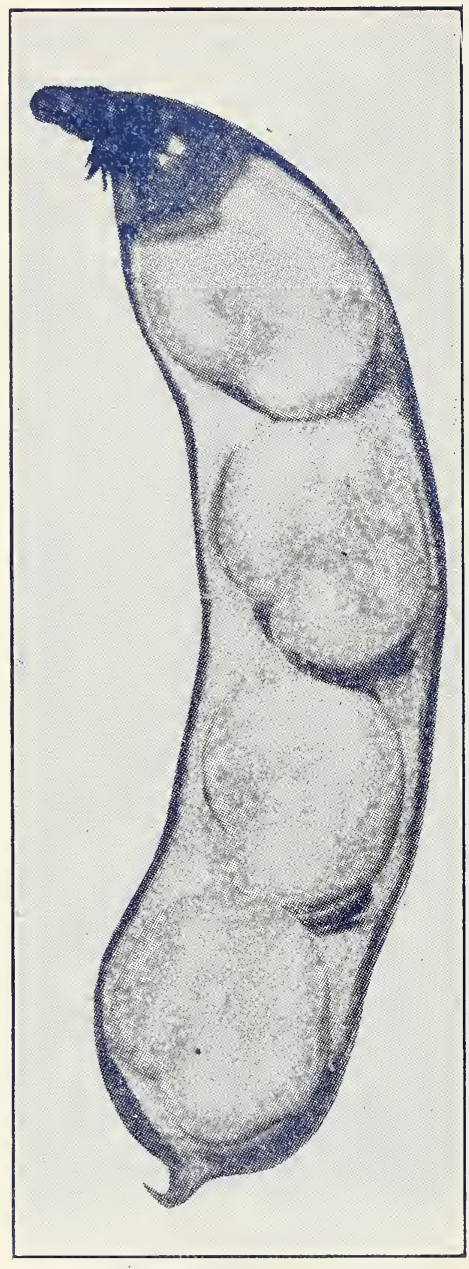

RICE'S MAMMOTH dry, hot weather, and don't fill out perfectly full every time, while the smaller varieties, both in the bunch and pole, do splendid. This class of beans is more tender and more susceptible to cold than ordinary bunch beans and cannot be planted so early in the spring. And again, they cannot usually be covered to the same depth. Butter Beans, to germinate satisfactorily, should be barely covered.

The Best Fertilizer-A large quantity of well-rotted stable manure thoroughly incorporated in the soil is best for Butter Beans, the object being to get the soil as loose and friable as possible. Lima Beans will do no good where the soil is hard and becomes baked.

Dwarf or Bush Varieties-The Dwarf Limas have become very popular from the fact that no supports are required in their growth, which is always a serious problem with town or city folks. In quality they can hardly be said to equal the running sorts. The dwarf sorts, however, are very prolific and a very small space in a family garden properly cultivated, will materially aid in lowering the cost of living. There is no better or more substantial vegetable than fresh green shelled Limas.

Burpee's Bush Lima-A dwarf type of the large white Lima Bean, of splendid quality, but does not fill out well in the South except on rich mellow soil. Pt., 25c; qt., 40c; pk., $\$ 2.50$; bu., $\$ 8.50$. By mail, postpaid, pt., $35 \mathrm{c}$; qt., $55 \mathrm{c}$.

Henderson's Dwarf Lima-This variety of Butter Bean $s$ the most popular and more largely planted in the South today than any other sort. It is the main money crop with a large per cent. of the Birmingham truckers, who plant it in succession from April to September. It is a true dwarf of the small running Lima. The dry bean is small, flat and nearly round. Plants grow from eight to twelve inches tall, and rarely show any disposition to run. It is very early, exceedingly prolific, and stands the dry, hot weather at the South better than any other bean. They should be planted on rich soil and well cultivated. The yield is surprising. Pt., 20c; qt., 35c; pk., $\$ 2.00$; bu., $\$ 7.50$. By mail, postpaid, pt., 30c; qt., 50c.

Tall or Pole Varieties-We unhesitatingly recommend the tall varieties of Limas in preference to the dwarf sorts to those who can provide poles, trellises, harbors or fences for their support. The running Lima makes a splendid shade vine for porches and, while performing such functions, will also provide a bountiful crop of the best of vegetables. The best variety for the South generally in the pole sorts, is the Carolina or Sieva, known also as the old-fashioned Butter Bean. While it is not as large, as the large white or mammoth, it is more prolific and fills out better. The tall Limas are more easily shelled than the dwarf sorts, another desirable feature. Our customers will find our stock pure and unmixed.

Carolina or Sieva (Small Running Butter Bean)-This is the best Butter Bean for the South. It is the only sort that will stand long sieges of hot, dry weather, and continue bearing, until killed by frost in November. It is enormously prolific, fills out well, is easily shelled, and unexcelled in quality. Pt., 20c; qt., 35c; pk., $\$ 2.00$; bu., $\$ 7.50$. By mail, postpaid, pt., 30c; qt., $50 \mathrm{c}$.

Rice's Mammoth-A mammoth size variety, producing heavy foliage. A prolific sort and of fine quality. The dry bean is exceedingly large, but unless planted in rich, moist, loose situations will suffer from dry heat. Pt., 20c; qt., 35c; pk., $\$ 2.00 ;$ bu., $\$ 7.50$. By mail, postpaid, pt., 30c; qt., 50c,

Large White Lima-The standard variety of large pole Lima. It is late, prolific, of good quality' and will stand hot weather better than any other large sort. Fine for bottom lands or any rich loose' moist situations. Pt., 20c; qt., 35c; pk., \$2.00; bu., \$7.50. By mail, postpaid, pt., 30c; qt., 50c. 


\section{Beets for Table Use}

How to Grow-Any soil that will grow good crops of potatoes or turnips is best for Beets. They will not do much in poor, sandy situations, except through the use of considerable fertilizers, Potash is one of the essential elements of plant food in growing Beets. A good formula is two hundred pounds acid phosphate, two hundred pounds cotton seed meal, fifty to seventy-five pounds sulphate of potash; this for an acre in drills. Beets may be planted in the open ground in Alabama from February to October. They are frequently planted in cold frames or hot beds in November and December, to be transplanted in February and March.

Birmingham Early-This variety is the very earliest beet in cultivation. It is largely used in the South for forcing in cold frames or hot-beds for early markets. The variety produces but little foliage and a medium sized smooth root of globular shape and of a rich cardinal red color. We have seen this variety in rich situations large enough to bunch in forty to forty-five days. This is a splendid sort to grow in connection with other late sorts. It will

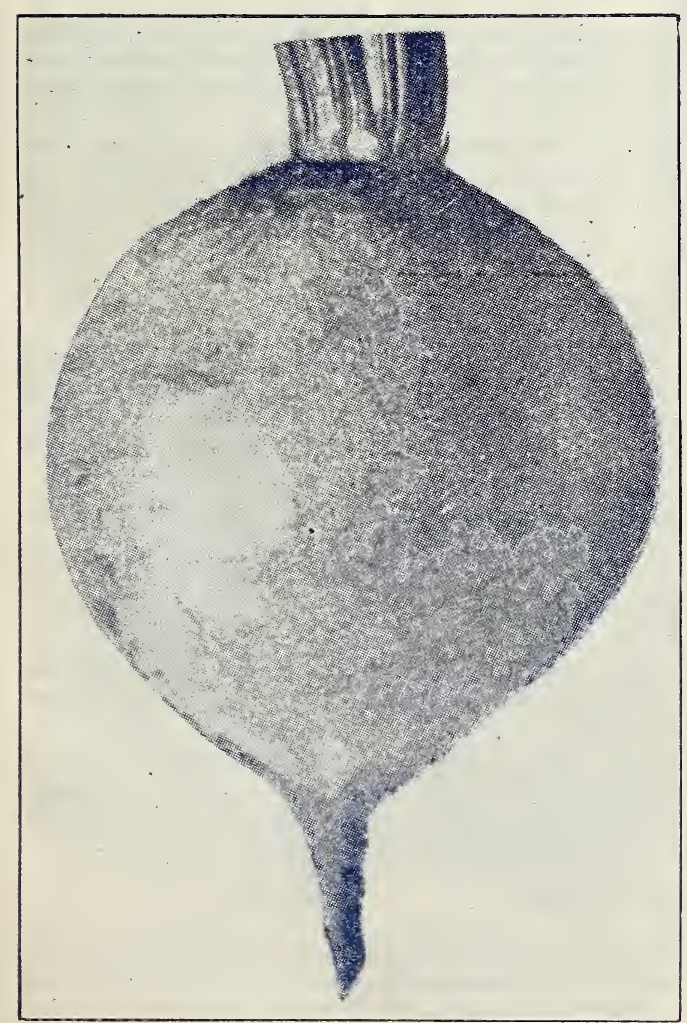

DETROIT DARK RED

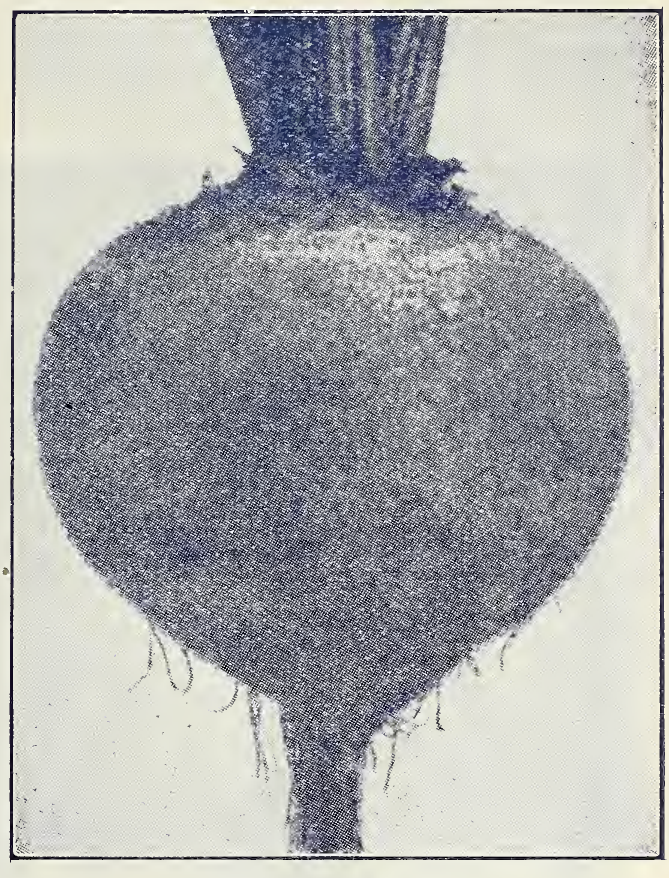

BIRMINGHAM EARLY

be gone by the time other sorts come in. Pkt., $5 \mathrm{c}$; oz., $15 \mathrm{c} ; 1 / 4 \mathrm{lb}$., 50c; lb., $\$ 1.50$.

Early Dark Blood Turnip Beet-It is by far the hardiest of all the turuip varieties, and may be planted outdoors from April until October, and will produce the same as a turnip, spring or fall. It is of a rich, dark red color, and most excellent eating qualities. Pkt., $5 \mathrm{c}_{\text {; }}$ oz., 10c; $1 / 4 \mathrm{lb}$., 30c; lb., $\$ 1.00$.

Crosby's Extra Early Egyptian-This is the finest strain of early beet there is. It differs from the Common Egyptian in that it never has a hard, tough, woody neck; is thicker and of much better eating quality. Pkt., 5c; oz., $15 \mathrm{c} ; 1 / 4 \mathrm{lb}$., $40 \mathrm{c} ; 1 \mathrm{~b}$., $\$ 1.25$.

Extra Early Eclipse-A beautiful globeshaped variety of a dark, rich red color, and is unexcelled in eating qualities. Pkt., 5c; oz., $10 \mathrm{c} ; 1 / 4 \mathrm{lb}$., 30c; lb., $\$ 1.00$.

Improved Long Blood Beet-The beet is long and smooth; flesh a deep red, and is both tender and delicious. Pkt., $5 \mathrm{c}$; oz., $10 \mathrm{c} ; 1 / 4 \mathrm{lb}$., 30 ; 1 b., $\$ 1.00$.

Detroit Dark Red-It is a very dark red variety, fine globular-shaped, very smooth, small tops, flesh dark red with veins of lighter shade. It holds its color after cooking, making it a most popular sort. In earliness it follows behind Crosby's Egyptian. Pkt., 5c; oz., $15 \mathrm{c}$; $1 / 4$ lb., $50 \mathrm{c} ; 1 \mathrm{~b}$., $\$ 1.50$. 


\section{Stock Beets, Mangel Wurzels}

How to Grow-Experience has taught us in the South that owing to universal droughts in the fall of the year it is best to plant the Mangel in the early spring, as it requires a long time for this variety of beet to perfect its growth, and if started in the spring it will root deep enough to stand a severe drought in the fall without much danger of injury. The seed should be drilled in the early spring in rows three feet apart, and thinned to about a foot apart in drill. They can be easily

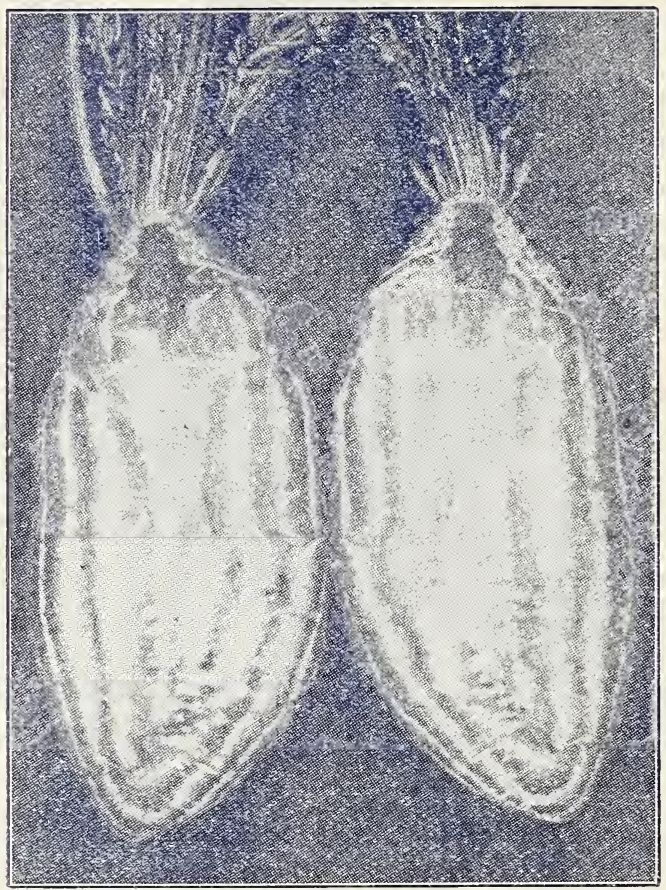

GOLDEN TANKARD transplanted the same as a table sort, and always produce larger roots by being transplanted. They require good cultivation. The crop should be taken up very carefully in the fall of the year, care being taken not to bruise the roots, as it will cause an early decay. The crop when first gathered is very acrid, and will badly scour cattle. They develop their best qualities after being kept awhile, and their value is estimated by the amount of saccharine matter they contain, which is from 6 to 8 per cent. of their gross weight.

Mammoth Long Red Mangel-This is the standard variety of Mangel everywhere, being the hardiest, more certain to produce well than any other sort; and very few growing larger. Pkt., 5c; 1/4 lb., 25c; lb., 75c.

Golden Tankard Mangel-A mammoth half-long variety, growing a greater part of its roots above ground, hence it can be raised successfully in thin soil. It is a great yielder, every root growing to uniform size, fine grain and excellent keeping quality. Pkt., $5 c$; $1 / 4$ lb., 25c; lb., 75c.

White Sugar-A variety possessing more saccharine matter than any other sort. A good keeper, exceedingly productive, and of the finest quality and texture. Pkt., 5c; oz., 10 c; $1 / 4$ lb., 25c; 1 lb., 75 c.

\section{Broccoli}

This vegetable was derived from the wild cabbage, and resembles cauliflower very much, but requires a much longer season to develop than the cauliflower. The seed should be sown in spring and transplanted in late summer into a very rich ground and watered occasionally. They will head by fall and make a fine dish boiled.

Walcheren-This is one of the hardiest sort, and best adapted to the South. Pkt., 5c; oz., 35c $1 / 4$ lb., $\$ 1.00 ; 1$ lb., $\$ 3.50$.

\section{Brussels Sprouts}

A vegetable very closely akin to the cabbage and collard. It may be treated in the South just like collards. It produces a peculiar erect stock, about one and one-half to two feet high, and bears numerous little sprouts shaped like a head of cabbage.

Perfection-This is the best variety for the South. The plant grows about two feet high, and produces from the stem numerous little sprouts, one to two inches in diameter, resembling cabbage. The sprouts are used as greens, and become very tender and rich when touched by frost. It should be sown in May and cultivated the same as cabbage. Pkt., 5c; oz., 15c; 1/4 lb., 50c; 1 lb., $\$ 1.50$.

\section{IMPORTANT NOTICE}

Refer to last page and read the information about the quantity of all kinds of seeds required for an acre or smaller areas. This matter has been carefully gotten together and is as near correct as possible. It is difficult to give this information in descriptive matter, as it would require too much space. A wide difference of opinion exists on this important subject. Read what we have to say. 


\section{Cabbage-Early Varieties}

All our Cabbage Seed are the best American grown, and from the best and most reliable growers on Long Island, N. Y. There are none any better, but plenty more high priced.

About Prices-Some trucksters and cabbage growers imagine that cabbage seed to be good must cost from three to five dollars a pound, and some seed men get such prices by preaching the superiority of their stocks.

Charleston WakefieldIt is a great improvement over the Jersey Wakefield in size, a sure header and well adapted to the South, where the variety originated. It is the only sort grown in some sections of the South; being a good keeper secures for it a good price in the markets. Pkt., 5c; oz., 25c; $1 / 4$ lb., $75 \mathrm{c}$; 1b., $\$ 2.50$.

Improved Early Drumhead Cabbage - The Drumhead Cabbage is the true Southerner, well adapted to the South, stands the long summer heat, and produces large heads. Pkt., 5c; oz., 20c; $1 / 4$ lb., 50c; lb., \$1.75.

Henderson's Early Summer Cabbage-It is much earlier than most of the flatheaded varieties, and pro-

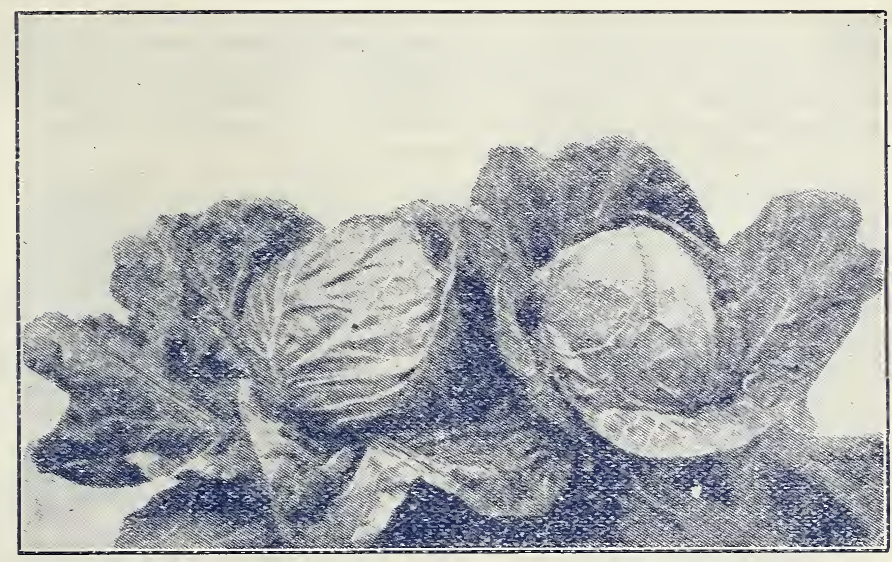

CHARLESTON WAKEFIELD

duces very few surplus leaves, all going to head if planted on rich ground and the season not too dry. It is well adapted to the South, standing the heat and drought well, and under favorable conditions will produce heads from ten to twenty pounds in weight. Pkt., 5c; oz., 20c; 1/4 lb., 60c; lb., \$2.00.

Early Jersey Wakefield - This is one of the most popular of all sharp-headed varieties, exceedingly early, very hardy, and one of the surest to head. As a market variety it cannot be excelled, always finding ready sale on account of its uniform size; does not grow too large or small, and can be relied on for excellent flavor. Pkt., 5c; oz., 25c; 1/4 lb., 75c; lb., \$2.50.

Early Winningstadt-An extremely early, sharp-headed variety, producing a head of fair size, and the very best eating and keeping qualities. Pkt., 5c; oz., 20c; $1 / 4 \mathrm{lb}$., 50c; lb., $\$ 1.50$.

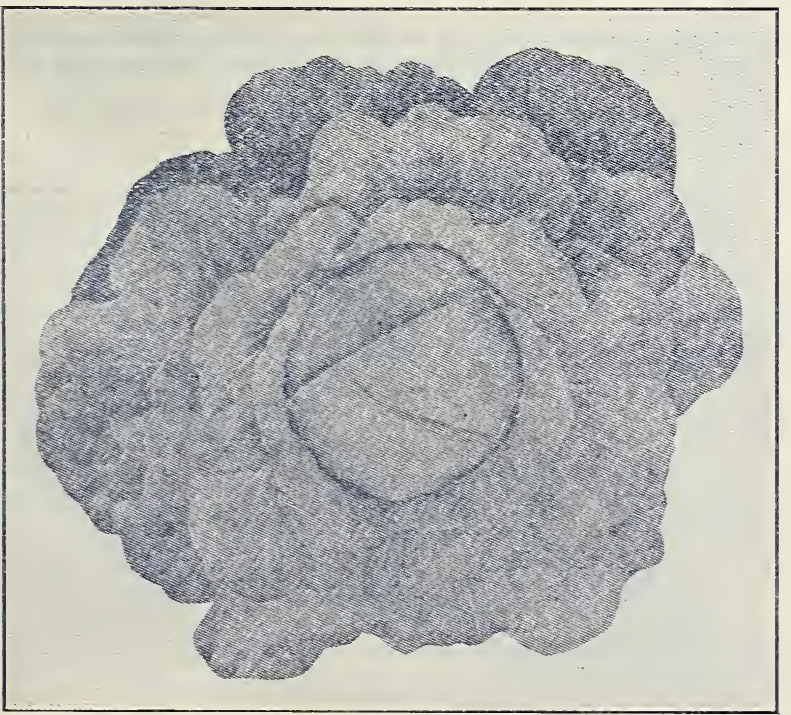

THE DOLSEN

Early Dwarf Flat Dutch-One of the best large-heading sorts known. It is about as early as the earliest, and its great size and solidity renders it very profitable. Pkt., 5c; oz., 25c; $1 / 4$ lb., $75 \mathrm{c}$; lb., $\$ 2.50$.

All-Head Cabbage - A sureheading variety in the South, standing the heat well, producing very few surplus leaves, most all going into its large, broad, flat head. It is being largely planted in the South for early shipment to Northern n.arkets. Pkt., 5c; oz., 25c $1 / 4$ lb., $75 c$; lb., $\$ 2.50$.

\section{WRITE US ABOUT CABBAGE PLANTS}

The Dolsen-The earliest and largest of flat or oval headed sorts. Under proper conditions will produce heads in 90 to 95 days after sowing the seed. The stem is short, foliage of deep green, few surplus leaves, head extremely hard and of surprising density. The quality is superb. Its a fine shipper and matures right along behind the Wakefield. Its the Cabbage to sell by weight, size five to fifteen pounds. Pkt., $5 \mathrm{c} ; \mathrm{oz} ., 35 \mathrm{c} ; 1 / 4 \mathrm{lb}$., $\$ 1.00 ; 1 \mathrm{~b} ., \$ 3.50$. 


\section{Cabbage - Late Varieties}

It is popularly supposed that one cannot have Cabbage in the fall and winter, and strange, too, since you see Cabbage on the market every day in the year. . The truth about the matter is, very few people endeavor to grow Cabbage to mature in the fall, notwithstanding it's easy. The Savoy varieties are just as hardy as a Collard and will stand in the open all winter with no protection whatever, while most any of the hardy sorts with slight protection, will carry through winter.

For fall and winter use, seed should be sown in beds the latter part of June and July, giving slight protection from sun, and when plants are about four inches high transplant to other beds and keep well worked. The main object is to get large stocky plants to reset in the open about September the first. After resetting, the plants must be worked almost continually in order to mature before November, as they will grow but little after that. They may then be dug up, root and all, and set out in trenches close together, where they can be protected by a wind-brake, shelter or a covering of straw. This_is_a practical method for the home gardener.

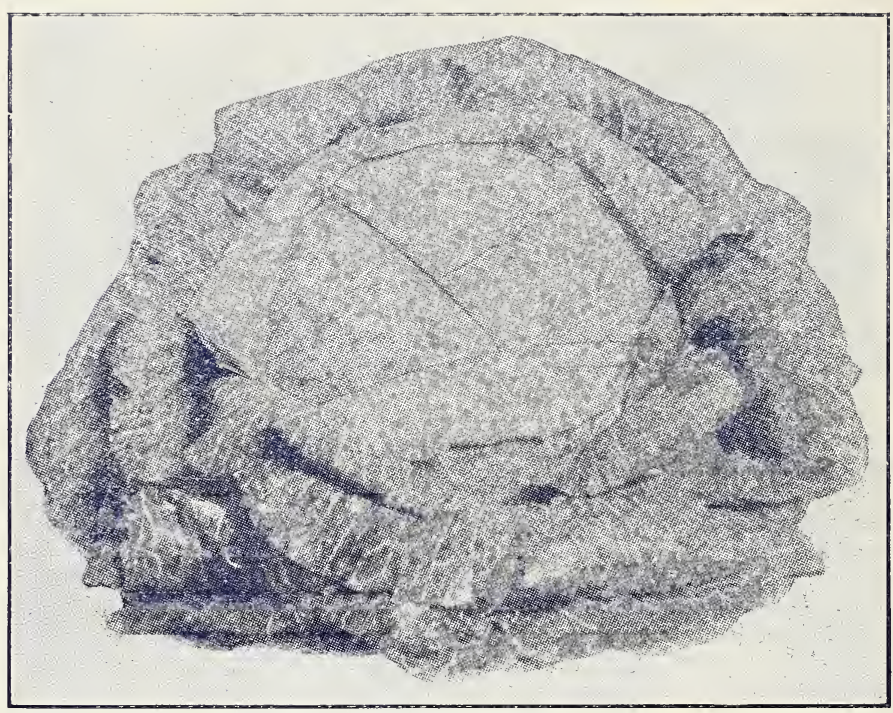

WINTER KING
Winter King-This is a large Danish Cabbage, one of the main crop sorts grown in Denmark. It has been bred in a cold climate. Our seed of it come direct from Denmark, and when planted in Alabama is almost frost proof. The heads are very large, flat to oval, very compact and hard; leaves thick and leathery and of decided markings and color. Its worth trying. Pkt., 5c; oz., 35c.

Surehead-A large, reliable heading sort, very popular in the South for both spring and fall use. Pkt., 5c; oz., 20c; $1 / 4$ lb., 60 c; lb., $\$ 1.75$.

Large Late Flat DutchFor a main or fall crop of large flat-heads nothing is superior to this sort. It is very hardy, a reliable header, and never disappointing when a good strain is planted. Pkt., 5c; oz., 20c; 1/4 lb., $75 \mathrm{c}$; lb., $\$ 2.50$.

Large Late Drumhead-This is equally as good Cabbage as the Flat Dutch, differing only in the shape of the head, not being so flat. It will stand the changeable conditions of weather at the South better than most any sort. Pkt., 5c; oz., 20c; 1/4 lb., 60c; lb., $\$ 2.00$.

Succession-This is one of the earliest of the very large heading sorts. Very profitable for a main spring crop. Pkt., 5c; oz., $25 \mathrm{c} ; 1 / 4 \mathrm{lb}$., $75 \mathrm{c} ; 1 \mathrm{~b}$., $\$ 2.50$.

Quality-This is what counts in Cabbage Seed. You can buy at any price, but cheap seed will fool you.

Autumn King-A quick-heading winter sort, heads broad and flat, stems very short, and few surplus leaves; resembles a Savoy, but much larger. Pkt., 5c; oz., 20c; $1 / 4 \mathrm{lb}$., $60 \mathrm{c} ; \mathrm{lb}$., $\$ 2.00$.

Mammoth Red Rock-A hard-heading sort of beautiful dark red color, very resistant to both cold and heat. Pkt., $5 \mathrm{c}$; oz., 20 c; $1 / 4$ lb., 60 c; lb., $\$ 2.00$.

Danish Ball Head-A very hardy fall variety; heads round, exceedingly hard and unexcelled in keeping qualities. Pkt., $5 \mathrm{c}$; oz., 20c; $1 / 4$ lb., 65c; lb., $\$ 2.00$.

Volga-A comparatively new sort of remarkable quality; flat head; a splendid market sort. Pkt., 5c; oz., 25c; $1 / 4$ lb., $75 \mathrm{c} ; 1 \mathrm{~b} ., \$ 2.50$.

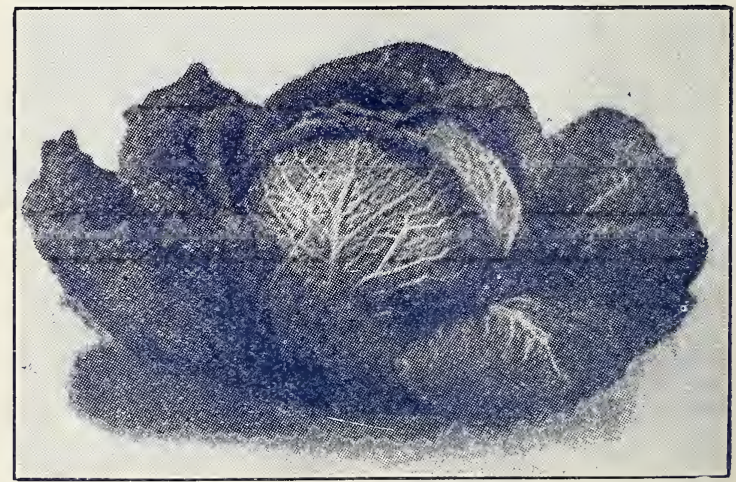

AMERICAN DRUMHEAD SAVOY

American Drumhead Savoy (Winter Cabbage)-This is the leading Savoy Cabbage grown, the most hardy and attaining a good size. It takes a remarkably hard spell of cold weather to kill this Cabbage. Its growth is very much like a Collard, being greatly improved by frost, rendering it tender and deliciouş. Pkt., 5c; oz., 20c; $1 / 4$ lb., 60c; lb., $\$ 2.00$. 


\section{THE PLAIN TRUTH ABOUT SEED MEVAY SEED AND FLORAL COMPANY}

\section{Carrot}

How to Grow-Carrots, like beets, require a very deep, rich soil; but most any land can be made to produce Carrots if plowed very deep and a liberal quantity of fertilizer used. The seed should be sown thickly in drills two feet apart. Keep the plants clear of weeds and work often and well. The crop may be gathered in the fall, the same as sweet potatoes, and stored in like manner. They are especially recommended for feeding milk cows, horses, sheep and goats.

The Best Fertilizer-The Carrot, like all other root crops, requires a good deal of potash. A good fertilizer would be acid phosphate and stable manure, and a liberal amount of kainit or muriate of potash.

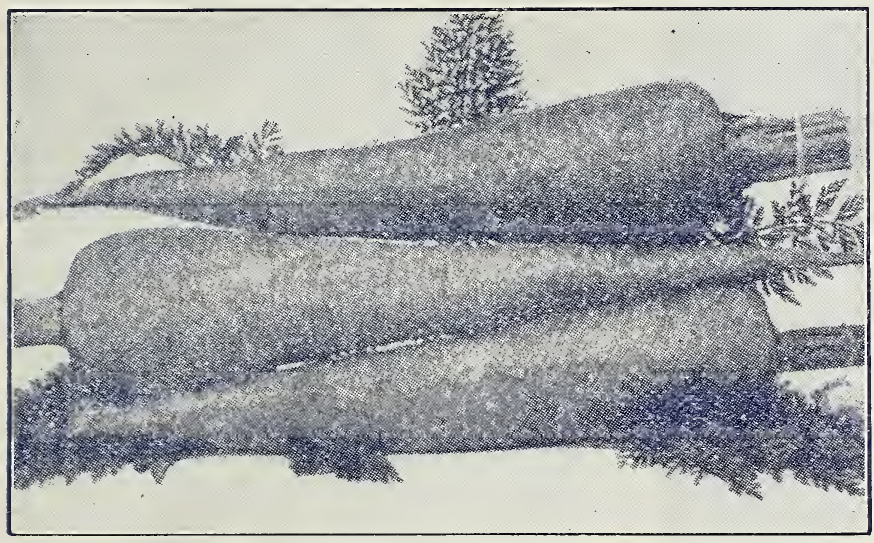

SAINT VALLERY

Saint Vallery (See Cut)This is the handsomest Carrot grown. The roots are long pointed, and the color of salmon pink. It is noted for its smoothness and excellent flavor. It is medium early, requiring about seventy days to mature. It is known commercially as the Red Carrot. Pkt., 5c; oz., 15c; $1 / 4$ lb., $40 \mathrm{c}$; lb., $\$ 1.25$.

Half-Long Danvers Carrot-This is one of the largest yielders of all the varieties often yielding from 25 to 30 tons per acre. It is of medium length and easily dug. The top is smooth and the variety of highest quality. Pkt., 5c; oz., 10c; $1 / 4$ lb., 30c; 1b., $\$ 1.00$

Improved Long Orange -It is largely planted for a general crop, producing long, Pkt., 5c; oz., 10c; 1/4 lb., 30c;

beautiful roots that sometimes attain the enormous length of two feet. lb., $\$ 1.00$.

Early Scarlet Horn Carrot-The color is a deep orange, flesh very fine grain and of delicious flavor. It grows to a length of four to five inches, and will yield abundantly in shallow soil. Pkt., $5 \mathrm{c} ; \mathrm{oz} ., 10 \mathrm{c} ; 1 / 4 \mathrm{lb} ., 30 \mathrm{c}$; lb., $\$ 1.00$.

Large White Belgian-This variety is extensively grown for stock, and while the flesh is rather coarse it is a very good eating sort when young. The roots are white, upper parts being green and grows about one-third out of the soil. Pkt., 5c; oz., 10c; $1 / 4$ lb., 25c; lb., 75c.

\section{Cauliflower}

How to Grow-Cauliflower will grow on soil well adapted to cabbage, and the same methods of cultivation will answer. The seed should be sown in December in cold frame or hot bed, and the plants wintered over and made as hardy as possible. They must be put out just as early as danger of hard freezes have passed. Rapid cultivation is necessary to bring the plants to head before hot weather. The heads will be improved if the leaves are tied over it when beginning to form.

Early Snowball-It is extremely early and more likely to head than any other sort. Pkt., 10c; oz., \$2.00.

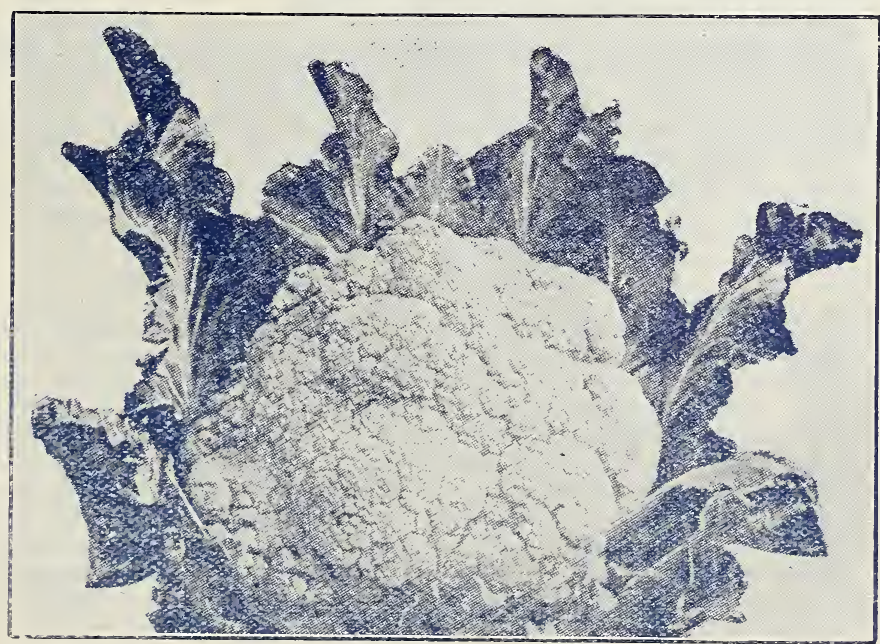

EARLY SNOW BALL 


\section{Celery}

How to Grow-Prepare a good seed bed in early spring by forking up the soil to a depth of twelve or fifteen inches, and have it moderately rich and well pulverized. Sow the seed thickly and keep well

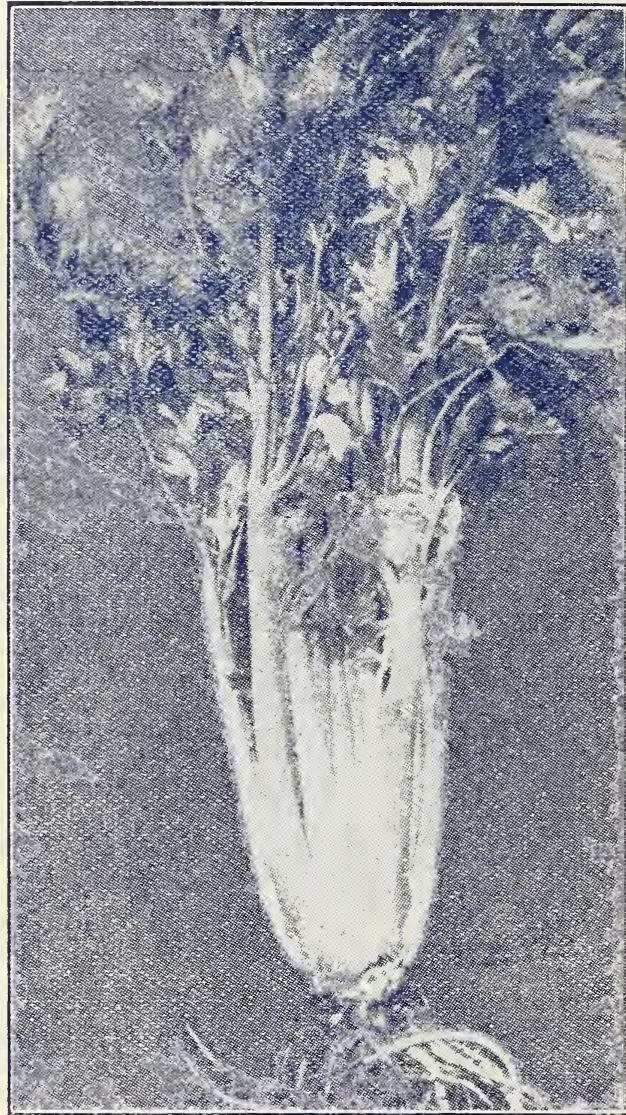

GOLDEN SELF-BLANCHING watered, allowing no weeds to make their appearance. When the plants are two or three inches high transplant to other beds prepared in like manner, and cultivate well. In the latter part of August or September these cultivated plants should be reset in rows three feet apart and four to six inches in drills. The soil for their final resting place should be made richer than the seed bed in which the plants were grown. Plants grown in this manner will come very rapidly if they are worked well, and when they have about attained their full growth the bleaching process should be given. We would recommend instead of pulling the earth up to the plants, to place boards along side of plants and pull the earth up against the boards to hold them in place, as a fewer per centage of the plants will rot if treated in this manner than if earth be used to bleach. It must be remembered that Celery does better on rich, mucky land, and where possible, select a place where there is an under strata of water near the surface. The object in bleaching Celery is to get rid of the acrid taste in the green stems. Celery may be stored for winter use and be bleached at the same time by digging out trenches about six inches deep and setting the stalks upright two or three inches apart and pulling up the earth to the top of the plants and covering with straw and a light dressing of manure on the straw.

Giant White Plume-An excellent variety, producing very large, broad stalks, very succulent and of elegant flavor. Pkt., 5c; oz., 25 c; $1 / 4$ lb., 75c; lb., \$2. 00 .

Golden Self-Blanching (See Cut)-It produces a straight, vigorous stalk and heart of rich golden color, very succulent, nutty, excellent flavor, and the tenderest in construction of any variety we know. The variety blanches easily the entire stalk, and may be eaten clean up to the leaves.

There is a great deal of difference between stocks of this variety of Celery as you can buy just as cheap as you want to, but if you get the genuine imported from a reliable French grower, as we do, then you can depend on results. American grown Celery of this variety is almost worthless. The genuine was scarce last season and sold as high as fifteen dollars per pound. Pkt., $10 \mathrm{c}$; oz., $\$ 1.50$. Write for price in quantity.

15 Celeriac or Turnip Rooted Celery-This plant produces a tuber somewhat like a turnip and tops like Celery. It is largely grown for the purpose of flavoring soups. Pkt., 5c; oz., $20 \mathrm{c}$.

\section{Collards}

To the average Southerner, any description of Collard would seem to be out of place. A great many people, however, coming to the South and even a great many natives, know little about this very staple vegetable. We doubt if any one knows where or when the Collard originated, but it is known, of course, that it is nothing but a hardy type of Cabbage, producing a great amount of loose leaves, but no solid heads. Its cultivation is the same as Cabbage, as the young plants are identical. It may be planted in the South from February to September. For winter use, the best time to plant is June and July, so the plants may get their full growth before November, because the Collard is greatly improved in flavor after they have had a good heavy frost or freeze. Most varieties are mixed; in fact, it is hard to isolate a definite type, but all are good, so what's the use!

Georgia Whitehead or White Stem-In quality this variety is far superior to any other. It is more like cabbage in growth, stocky, the leaves have white stems or veins, and where given distance on rich soil and the proper cultivation will produce small sized heads. It is just as hardy as any other sort, much tenderer, and eats well long before frosted on. Pkt., 5c; oz., 10c; 1/4 lb., 25c; lb., 75c.

Southern or Georgia-Most popular sort grown. Pkt., 5c; oz., 10c; $1 / 4$ lb., 25c; lb., $75 \mathrm{c}$. 


\section{Seed Corn}

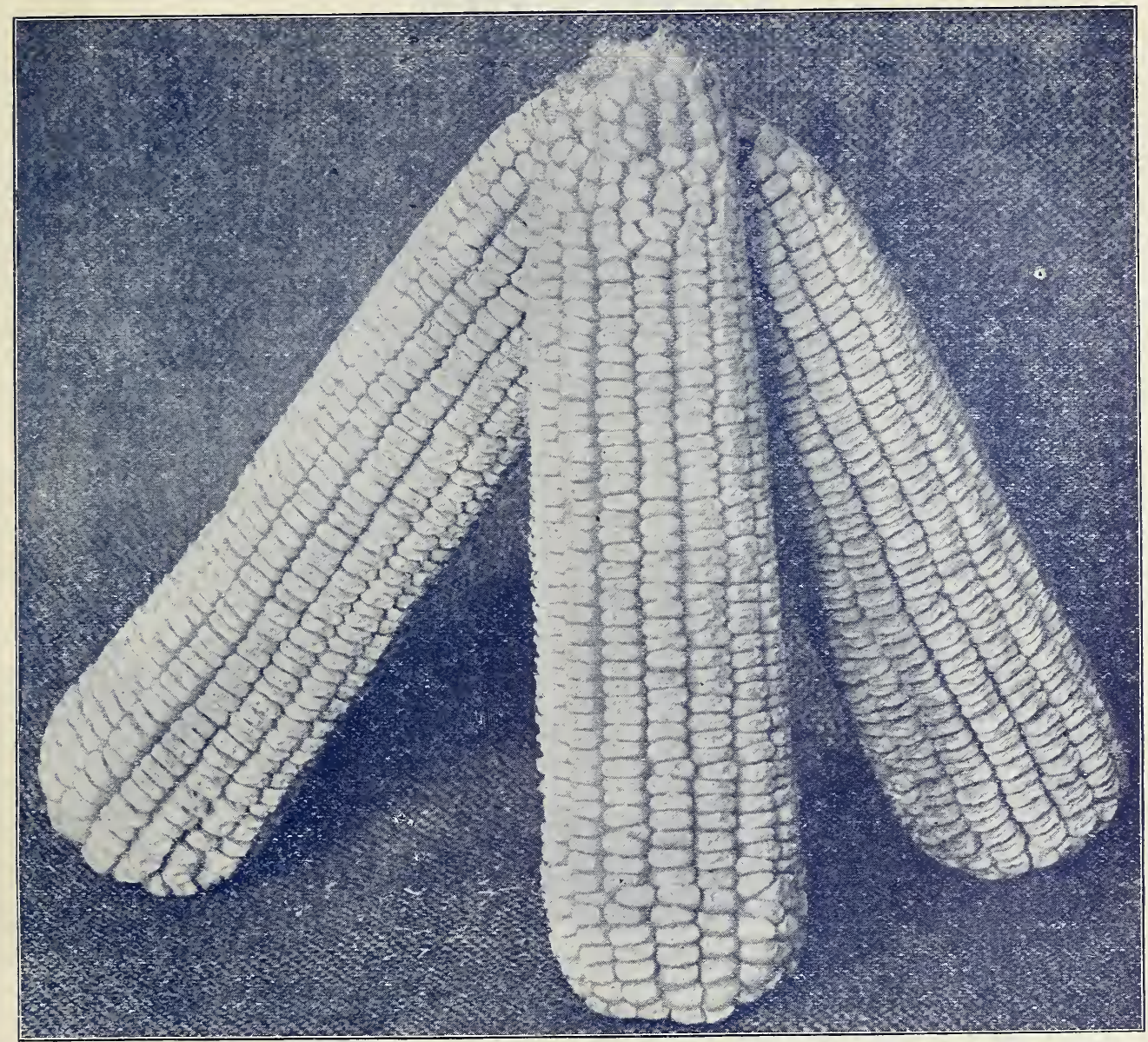

DAVIS PROLIFIC OR POOR LAND CORN

Davis Prolific-We believe this to be the best type of prolific corn grown. It has been bred to two ears to the stalk, so as to develop size and avoid four or five nubbins, characteristic of some prolifiic sorts. Ears average eight to ten inches long, rows twelve to sixteen grain long, pointed, medium hard, medium size, evenly lined and firmly set on small white cob. The variety fills out well both tips and buts; in fact, the ear, owing to smallness of cob, is practically all corn. Our stock is exclusively from Clarendon Davis, of Madison County, Ala., the originator. Pt., 10c; qt., 15c; pk., 75c; bu., \$2.75. By mail, postpaid, pt., 20c; qt., 30c.

Mosby's Prolific-A very popular prolific variety in the South, resembles the Davis Prolific, only the type is not so well fixed, the cob being larger and ears not so uniform in size. We have some fine Mississippi grown stock to offer. Pt., 10c; qt., 15c; pk., $75 \mathrm{c}$; bu., $\$ 2.75$.

Marlboro Prolific-We grow this variety in North Carolina in a section where no other sorts are grown, and our stock is pure. It is medium early, a vigorous grower, stalk averaging two or more ears of medium size. Grain white, hard and a splendid keeper. Yields of over a hundred bushels on good soil are often reported. Pt., 10c; qt., 15c; pk., 75c; bu., $\$ 2.75$. By mail, postpaid, pt., 20c; qt., 30c.

Snow Flake-This is the Corn for early roasting ears or for early maturity for any purpose. It can be planted as late as August first and still mature corn before frost. We have seen it mature roasting ears in fifty-five days from plantings. Ears average eight to ten inches long, rows sixteen to eighteen, cob white, medium small, grain good size, and pure white; stalks grow six to eight feet high only. Pt., 10c; qt., 15c; pk., 65c; bu., $\$ 2.25$. By mail, postpaid, pt., 20c; qt., 30c.

Hickory King-A medium early, prolific variety, with very broad and firm, flat grain. The ears average about eight inches long. 'The cob is exceedingly small, not much larger than a man's finger, and has usually ten and twelve rows. For the production of meal it is not excelled by any sort. Pt., 10c; qt., 15c; pk., 6 c ; bu., \$2.25. By mail, postpaid, pt., 20c; qt., 30c.

Pop Corn-The pop corn of commerce is the White Rice variety. You can sell this sort if you grow it. It is the most prolific sort, and best in quality. Price, shelled, lb., 10c; Postpaid, 1b., 20c. 


\section{Seed Corn}

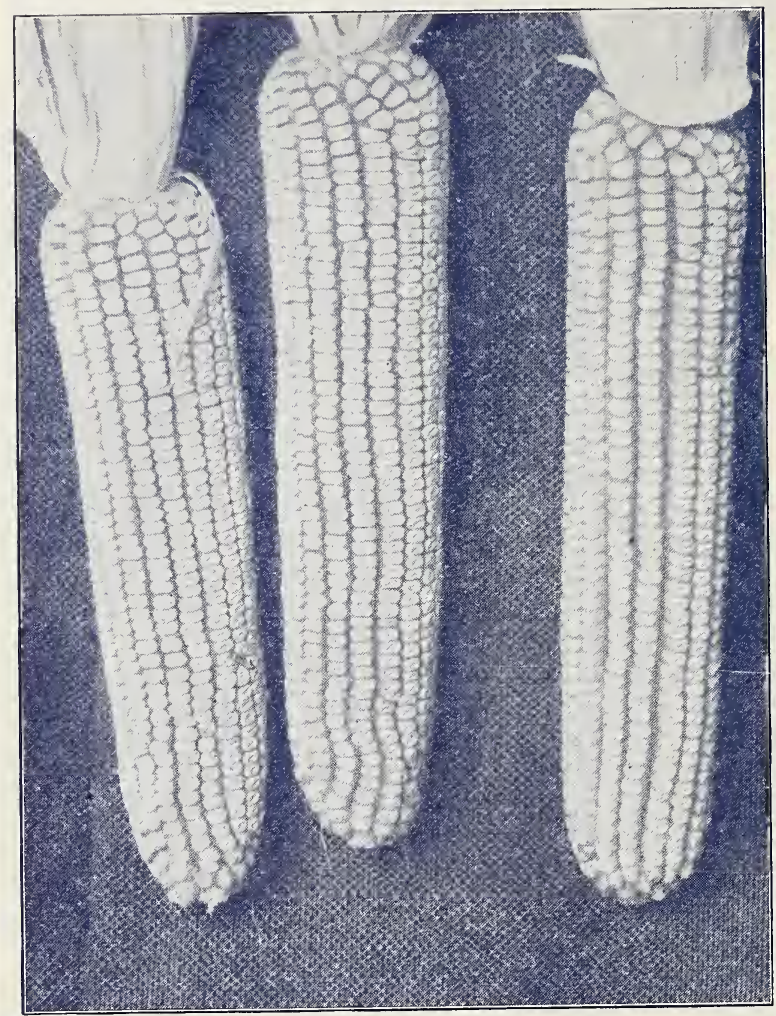

TYPES OF TENN. RED COB

Adams Early-This is the earliest type of corn grown. It is too small, of course, for anything except early roasting ears, but it is very profitable for this purpose if planted on very rich soil. Pt., 10c; qt., 15c; pk., 75c; bu., $\$ 2.75$.

Tennessee Red Cob-This is one of the standard white corns of the South and probably more largely grown than any other. It is a medium late sort, but well adapted to the climate and year in and out will show splendid yields. The stalk is a vigorous grower, a good drought resister, and on rich land a great many stalks will bear two ears. The ear is very large, ten to twelve inches long, having eighteen to twenty-two rows. The grain itself is very large, being long and broad. The cob is mostly red and rather large. As an all-round stock corn, it is one of the best. Our stock is Tennessee grown

Pt., 10c; qt., 15c; pk., 65c; bu., \$2.25. By mail, postpaid, pt., 20c; qt., $30 \mathrm{c}$.

Mexican June-A desirable white variety to plant from June to A'igust first, a great drought resister and will thrive under conditions where other sorts would not survive. If interested in this corn, write for special information. Pt., $15 \mathrm{c} ;$ qt., $25 \mathrm{c} ; \mathrm{pk}$., $\$ 1.00$.

Mammoth Yellow Dent-This is a large yellow Tennessee corn, growing to immense size, splendid yielder, an excellent keeper and one of the grandest of stock corns. Ears are often a foot long and have from 18 to 22 rows. We have some pure bred stock of this. Pt., 10c; qt., 15 c; pk., 65c; bu., $\$ 2.25$.

Early Golden Dent (See Cut)-Our stock is Northern grown, early and of splendid size. We illustrate here a single prize ear, exhibited at Alabama State Fair, October, 1912. You can't go wrong with this stock. Pt., 10c; qt., 15c; pk., 65 c; bu., $\$ 2.25$.

\section{Sugar or Sweet Corn}

Stowell's Evergreen-A standard variety of sweet corn, producing very large ears, grains deep and remains in edible condition longer than any other sort. Pt., 10c; qt., 20c; pk., $\$ 1.00$; bu., $\$ 3.50$. By mail, postpaid, pt., 20c; qt., 35c.

Country Gentleman-A popular sweet corn, producing fair size ears, long slim grains, unevenly distributed on cob, extremely sweet, and without question the best quality of any sweet corn. Pt., 15c; qt., 25c; pk., \$1.25; bu., \$4.50. By mail, postpaid, pt., $25 \mathrm{c}$; qt., $40 \mathrm{c}$.

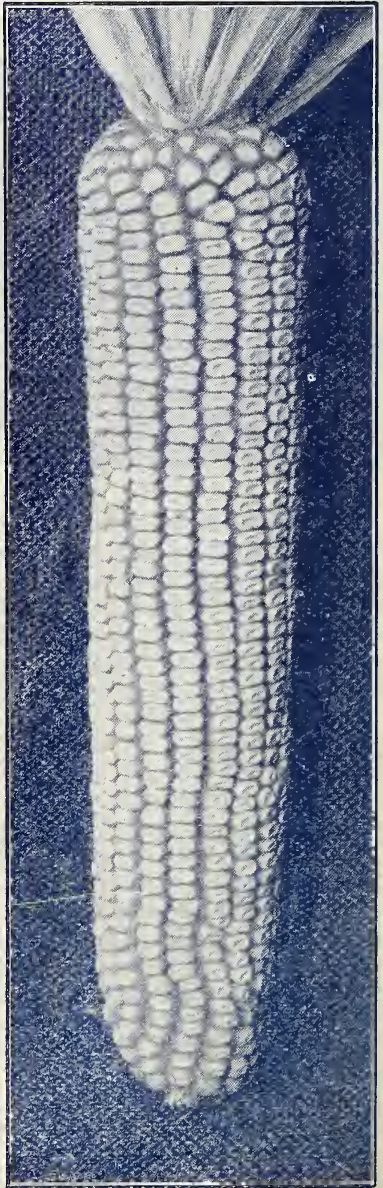

GOLDEN DENT 


\section{Cucumbers}

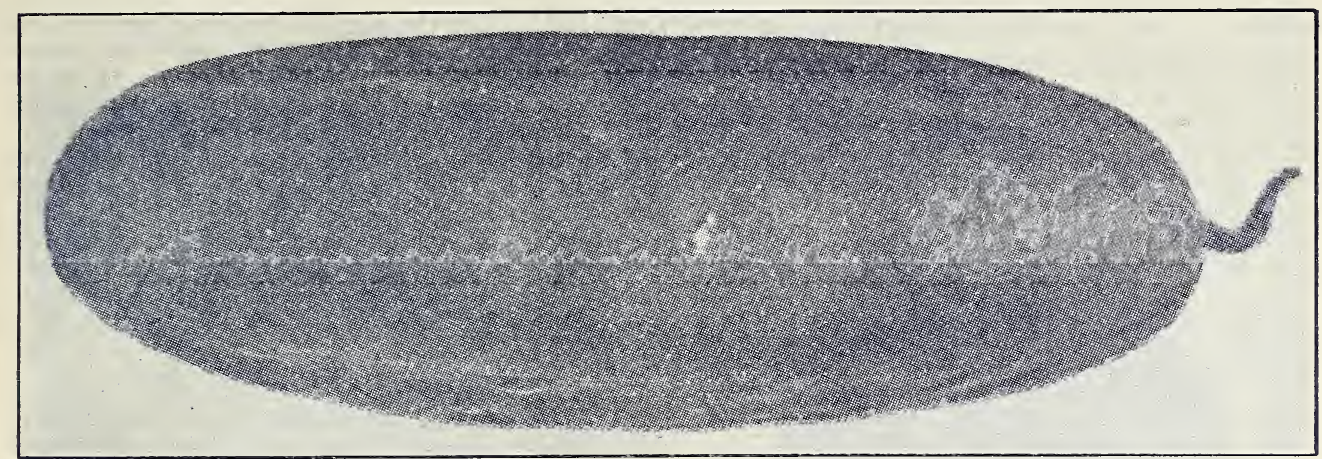

LONG DISTANCE-THE VERY BEST CUCUMBER

Long Distance-The above picture illustrates what we believe to be an extra choice cucumber for all purposes and for shipping. We doubt if its' equaled. The best features of this cucumber may be summarized as follows: It is early, very prolific, smooth, well rounded out, is void of necks, a deep green color which it holds a remarkably long time before turning yellow. It is medium in size, not too large, which is very much desired as too many sorts grow so large as to make them unpopular with the market man. The seed of this sort develops slow, the flesh is hard, firm and crisp, and does not possess such a strong odor that characterizes so many sorts. We want our customers to try it, if only a packet. Pkt., 5c; oz., 20 c; $1 / 4$ lb., 50c; lb., $\$ 1.50$.

Evergreen White Spine-This is the best type of White Spine Cucumber for both home and market use, especially for the latter. It is larger than ordinary White Spine, uniform throughout length, and the skin is a darker green, which it holds longer without turning yellow than common White Spine. We recommend it in preference to any other White Spine. Pkt., 5c; oz., 10c; $1 / 4$ lb., 30 c; lb., $\$ 1.00$.

Klondyke - This is a dark green cucumber of good size, thick, with blunt end, very early and prolific. It is largely grown in the South for shipment to markets because it holds its color well and does not rot as easily as some others. Pkt., 5c; oz., $10 \mathrm{c} ; 1 / 4 \mathrm{lb} ., 30 \mathrm{c} ; \mathrm{lb}$., $\$ 1.00$.

Davis Perfect-An extra large long green cucumber, grown largely for market on account of its size. The seed develop slowly, another good feature desired in a market sort, and it is claimed by some that they have found it the best selling variety. Pkt., 5c; oz., 10c; $1 / 41 \mathrm{lb} . .30 \mathrm{c} ; 1 \mathrm{~b} ., \$ 1.00$.

Long Green-The standard home variety, fruit long dark green, splendid quality, rather late, but has long bearing period but not well suited for market. Pkt., 5c; oz., 10c; $1 / 41 b ., 30 c ; 1 b ., \$ 1.00$.

Everbearing-An early, small sized, prolific sort, valuable for pickles or home use. Pkt., $5 \mathrm{c}$; oz., 10c; 1/4 lb., 30c; lb., $\$ 1.00$.

Chicago Pickle-A small, short green pickling sort, with prominent spines, fruit pointed at ends. It is very hardy and often grown in fall of year. Pkt., 5c; oz., 10c; 1/4 lb., 30c; lb., $\$ 1.00$.

Japanese Climbing - A splendid variety to grow on arbors or trellises, very showy and of good quality. Pkt., 5c; oz., 15c; $1 / 4$ lb., 50c; lb., $\$ 1.50$.

Gherkin or Bur-A peculiar variety grown altogether for pickles. Fruit oval, studded with spines. When gathered young can be turned into delicious pickles. Pkt., 5c; oz., 15c; $1 / 4$ lb., 50c; lb., $\$ 1.50$.

New Cluster-We have found this the earliest cucumber yet, bloom. ing before others and fruiting quicker. $\mathrm{Th}$ e fruit is short, light green and generally in clusters of three and sometimes four. Its bearing period is long and it's a good drouth resister. For the home garden it is par excellence. Pkt., $5 \mathrm{c}$; oz., 15 c; $1 / 4$ lb., 40 c; lb., $\$ 1.25$.

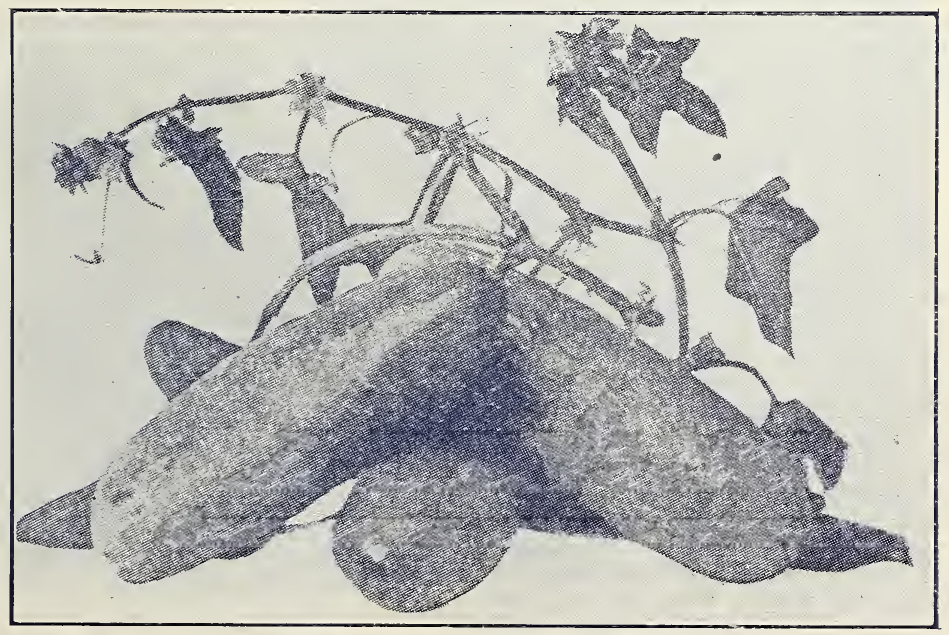




\section{Egg Plant}

How to Grow-For early use sow in well prepared hot-bed January, February or early in spring. and keep the beds well moist by watering, and keep well protected from the cold, as the plants are very sensitive to cold, which will dwarf them in growth and fruit. Let the plants remain in the hot-bed

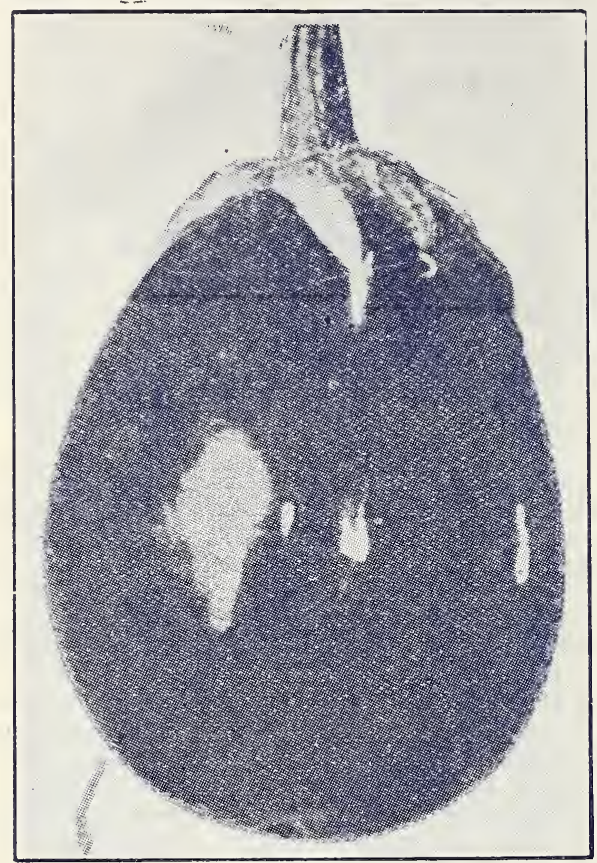

FLORIDA PURPLE until all danger of frost is over, and then transplant in rows two feet apart and about 18 to 24 inches in drills. Egg plants to be saleable must be of beautiful dark purple, and handsome form.

Florida Purple-This is an improvment on the New York Purple, making a larger and more erect bush and somewhat larger fruit. It is the best variety for shipping or home use. The variety is enormously productive, acclimated to the South, standing the heat and drouth better than other sorts. Pkt., 5c; oz., 25c; $1 / 4$ lb., 90c; lb., $\$ 3.00$.

\section{Endive}

White Curled Endive-One of the most beautiful varieties grown. The mid rib is yellow and the leaves almost pure white; fine for garnishing or eating. Pkt., 5c; oz., 10c; $1 / 4$ lb., 35c; lb., $\$ 1.00$.

Green Curled Endive -The hardiest variety of them all, standing outdoors most of the winter. The leaves are a beautiful dark green, very crisp and tender; will blanch pure white in center. Pkt., $5 \mathrm{c} ;$ oz., 10c; 1/4. 1b., 35c; 1b., $\$ 1.00$.

\section{Kohl-Rabi}

How to Grow-For an early or late crop it should be cultivated the same as cabbage. The vegetable is grown for its turnip-shaped bulb, which is formed above the ground by the expansion of the stem. The bulb should be used while young and tender, as age detracts from its good qualities.

Early White Vienna-It is very early, a rapid grower, and produces a good sized bulb of light green color, which is exceedingly tender and delicious. Pkt., 5c; oz., 20c; 1/4 lb., 65c; lb., $\$ 2.00$.

\section{Kale}

How to Grow-A variety of plant belonging to the cabbage family, producing one of the most delicious salads grown. May be grown in the same manner as cabbage, or can be broadcasted as turnips.

Dwarf Curled Scotch Kale (See Cut) - A very dwarf early sort, a vigorous grower, producing beautiful curly leaves and spreading largely. Pkt., 5c; oz., 10c; 1/4 lb., 35c; lb., $\$ 1.00$.

Tall Curled Scotch-A tall growing hardy, very curly variety of kale. It's growth is sometimes two feet in height, holding its foliage wcll above the ground. Pkt., 5c; oz., 10c; $1 / 41 \mathrm{lb} ., 35 \mathrm{c} ; 1 \mathrm{~b} ., \$ 1.00$

Siberian-A vigorous growing variety, producing large, broad, grayish green leaves, only slightly curled at the edges. It stands more heat and cold than any other sort. Pkt., 5c; oz., 10c; $1 / 4$ lb., 25c; lb., $75 \mathrm{c}$.

\section{Leek}

How to Grow-The seed should be sown early in hot-beds, if you have one; if not, sow in a seed bed in some sheltered place, if possible. When the plants are about six inches long transplant them in drills six inches deep, with very rich soil at the bottom. Fill in the trenches as the plants begin to grow, and keep pulling up the dirt as plants advance. The Leek requires very deep strong soil, fertilized roadcast with coarse stable manure.

London Flag-One of the largest and finest Leeks grown; very early and of excellent flavor. Pkt., 5c; oz., 15c; $1 / 4$ lb., 50c; lb., $\$ 1.50$.

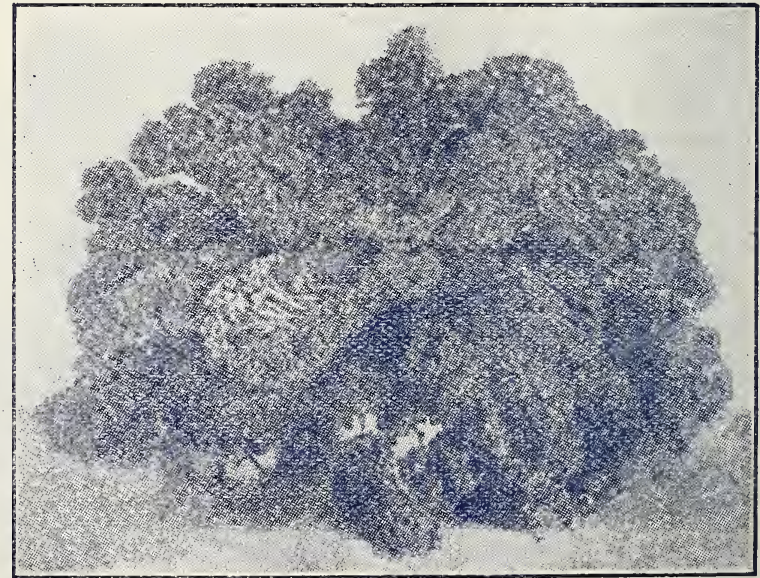

KALE-DWARF CURLED SCOTCH 


\section{Lettuce}

How to Grow-If you are prepared with hot-beds lettuce may be grown at any time or month in the year by selecting forcing varieties that will form heads under glass. It may be grown out of doors in the South from early spring until frost. The best way to grow lettuce is to sow the seed in a

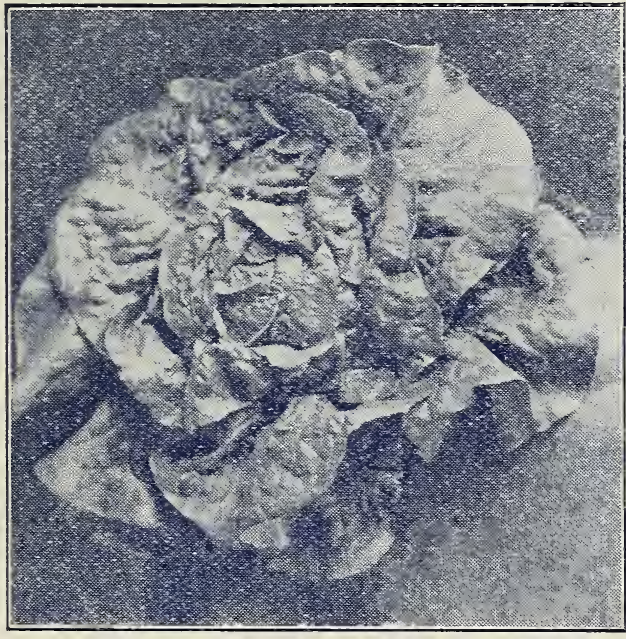

BIG BOSTON bed of rich earth, and when plants grow off transplant in rows about two feet a part, and about six to ten inches in drill, and cultivate like cabbage. The soil should be rich and its growth pushed, in order to produce crisp, tender heads. It should not be sown on a bed thickly, and allowed to remain and grow up spindling and become tough, go to seed early and die out entirely.

The Best Fertilizer-Lettuce in order to be good must be grown quickly, and there is but little danger of fertilizing too heavy. Nitrate of Soda should be used liberally.

Big Boston-This is the most popular lettuce among market gardeners for either outdoor, cold frame or hot-bed culture. It is a certain header, early and of splendid quality. The difficulty is getting pure seed, but we take no chances on this, and know that our stock is as pure as can be had. Pkt., $5 c$; oz., 15c; $1 / 4$ lb., 40c; lb., \$1.25.

McVays Butter-This is a medium late variety especially suited for second or summer crop. It stands the heat and remains longer without going to seed than others. It is very hardy and may be planted very early or in summer or early fall, right out in the open. A sure header, forming large compact, heavy heads of exceptional quality. Pkt., $5 \mathrm{c} ; \mathrm{oz} ., 15 \mathrm{c} ; 1 / 4 \mathrm{lb}$. , $40 \mathrm{c} ; \mathrm{lb} ., \$ 1.25$.

Paris White Cos (Romaine)-This is a distinct type of lettuce very popular with all Latin races. The plant produces great spoon shaped leaves, which are thrown upright into sugar-loaf shaped heads, the inside of which blanch almost white. The inside leaves are very tender, crisp and of exceptional good flavor. Pkt., 5c; oz., 15c; 1/4 lb., 40c; lb., \$1.25.

Grand Rapids-A popular, loose leaved sort, in great favor among Southern truckers for shipment to Northern markets. It is a hardy and vigorous grower, and its beautiful curly leaves make it a showy and saleable variety. Pkt., 5c; oz., 15c; 1/4 lb., 35c; lb., \$1.00.

Early Hanson-A large, early sort, producing good sized heads, very crisp, tender and almost white. It does very well under glass, if given distance, but succeeds better outdoors on account of its size and rank growth. Pkt., 5c; oz., 15c; $1 / 4$ lb., $35 \mathrm{c} ; 1 \mathrm{~b} ., \$ 1.00$.

Black Seeded Tennis Ball-One of the finest sorts for hot-bed culture we know of. This variety is extremely hardy, a quick grower, almost round, solid heads, inside leaves white, crisp, very tender and of the most delicate flavor. It is always the first hot-bed lettuce on the Birmingham market. It succeeds well under glass, growing stocky and never fails to head. Pkt., 5c; oz., 15c; 1/4 lb., 40c; lb., \$1.00.

Winter Salad (Klondyke)-Stands all winter in South. A very desirable sort to plant in September; will afford lettuce the entire winter. Takes extreme weather to kill. Pkt., $5 c$; oz., 15c; $1 / 4$ lb., 40c; lb., \$1.25.

Early Prize Head-One of the best sorts for the South, standing the hot sun well, and remains in eatable condition a long time, and does not shoot up to seed. The leaves are tinged with bronze, making it a showy and saleable variety. Pkt., 5c; oz., 15c; $1 / 4$ lb., 35c; lb., $\$ 1.00$.

Black Seeded Simpson-An old time sort of splendid merit. It does not make a solid head, but a great mass of light green, loose, beautifully crimped leaves, all of which are very tender and of excellent flavor. Pkt., 5c; oz., 15c; $1 / 4$ lb., $35 \mathrm{c} ; \mathrm{lb}$., $\$ 1.00$.

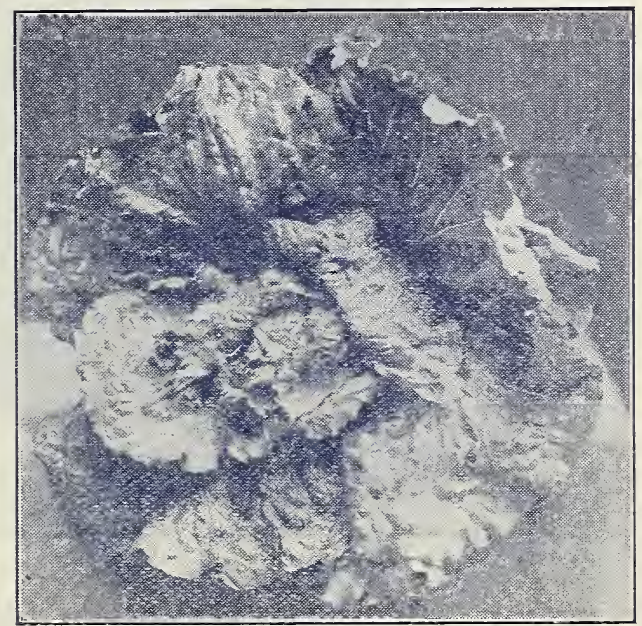

BLACK-SEEDED SIMPSON 


\section{Cantaloupe or Muskmelon}

I How to Grow-Thorough and deep preparation is the main necessity in growing cantaloupe. A crop of cow peas, vetch, crimson clover, etc., turned under is of great benefit to landintendedifor cantaloupe, the chief idea being to loosen the subsoil so the plants can establish a deep root system, and thus better withstand hot, dry weather. Cantaloupe should not be planted until danger of frost is passed-usually about the time the apple blooms. The hills should be about four and a half feet apart each way.. Several seed may be planted to the hill, but they should be thinned to one good, healthy plant.

The Best Fertilizer-Leaf mould, stable manure, well rotted, or four to six hundred pounds high grade complete commercial fertilizer applied to the acre under hill. Nitrate of soda broadcasted at the rate of one hundred pounds to the acre when the vines start to run is of great good.

Home Market-If you want size and quality combined, this melon will suit you. It has thick green flesh, very sugary and sweet. It is both early and prolific. The

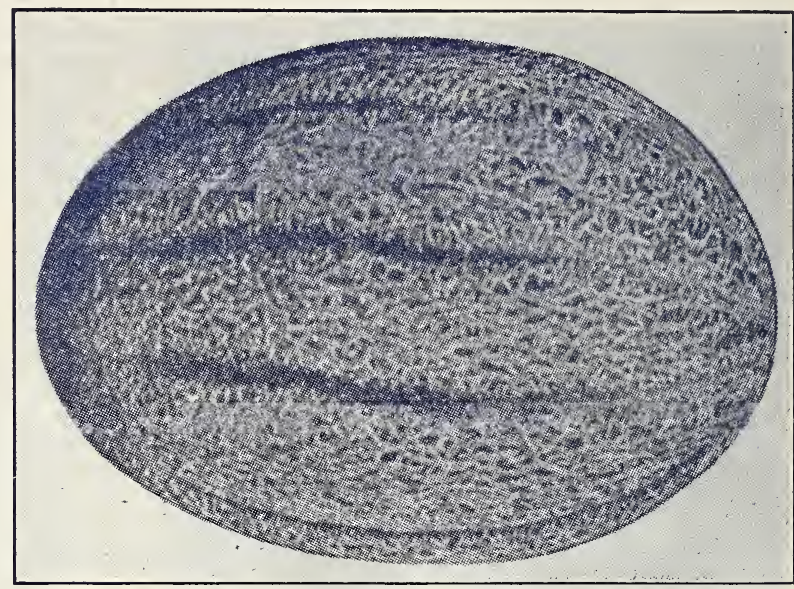

HOME MARKET

outer shell is hard and it does not easily bruise. It is most too large to ship, but will bring a fancy price in local markets. Pkt., 5c; oz., 10c; $1 / 4 \mathrm{lb}$., 35c; lb., $\$ 1: 00$.

Rocky Ford-The most popular shipping melon grown, and is hard to beat where a small melon is wanted. Fruit oval, slightly ribbed, flesh green, fading into orange at center, very sweet and spicy. We have genuine Colorado grown stock. Pkt., 5c; oz., 10c; 1/4 lb., 25c; lb., 75c.

Large Green Nutmeg-A large nutmeg sort, coarsely netted, deep rib, flesh thick, green; an excellent flavor. Pkt., 5c; oz., 10c; 1/4 lb., 30c; lb., $\$ 1.00$.

Long Yellow-This is the old-fashioned country musk melon, growing to large size. It is a bright yellow when ripe and good flavor. Pkt., 5c; oz., 10c; $1 / 4$ lb., 35c; lb., $\$ 1.00$.

Rocky For d-(Robinson Stock)

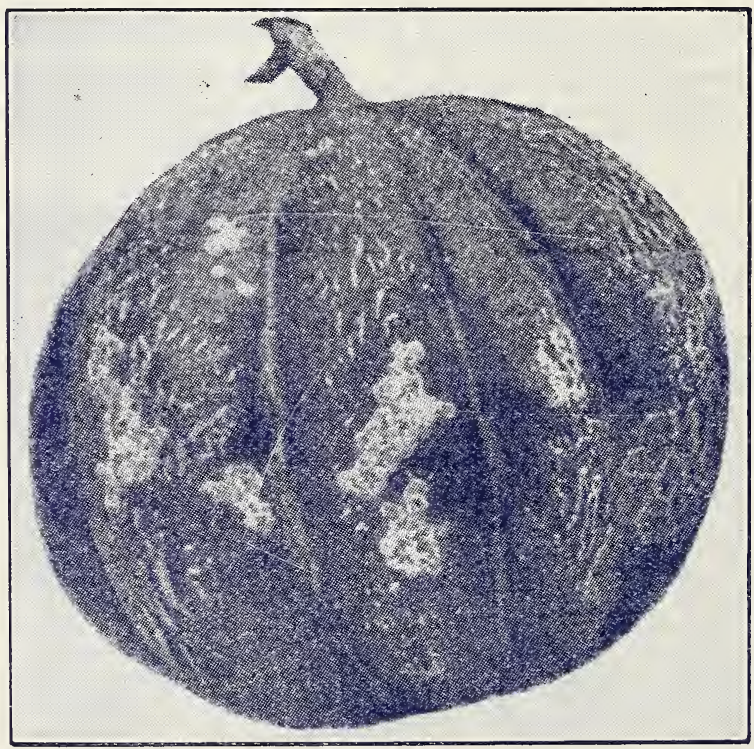

EMERALD GEM

This is a special Stock taken by hand from selected specimens, every fruit being perfect. Of course this stock is what the large growers should use because in shipping there is no loss from imperfect fruit. The extra cost of the seed cuts no figure in a crop. Pkt., 5c; oz., 20c; $1 / 4$ lb., 65c; lb., $\$ 2.00$.

Extra Early Osage-A very early and prolific, nearly round melon, netted over a great part of the outer surface; flesh very thick, of deep salmon color and fine odor and flavor. Pkt., 5c; oz., 10c; $1 / 4$ lb., 35c; lb., $\$ 1.00$.

Tip Top-A medium large greenish gray looking melon; flesh thick and of orange color. Highly recommended for home market. Pkt., 5c; oz., 10c; $1 / 4$ lb., 30c; lb., $\$ 1.00$.

Acme-A large oval-shaped melon, resembling Rocky Ford, only much larger and just as good quality in every particular. We recommend it as a shipper as well as for home use. Pkt., 5c; oz., 10c; $1 / 4$ lb., 30c; lb., $\$ 1.00$.

Exrta Early Hackensack-A very early sort, medium in size, deeply ribbed and thoroughly netted;flesh green, spicy flavor, and in shape flattened at each

end. A splendid sort for home use.Pkt., $5 c$; oz., 10c; $1 / 4$ lb., $30 c$; 1b., $\$ 1.00$.

Emerald Gem-A distinct variety of green skin, flesh salmon color, rind thin but tough, everything going into meat. A splendid sort for home market. Pkt., 5c; oz., 10c; 1/4 lb., 30c; $1 \mathrm{~b}$., $\$ 1.00$. 


\section{Watermelons}

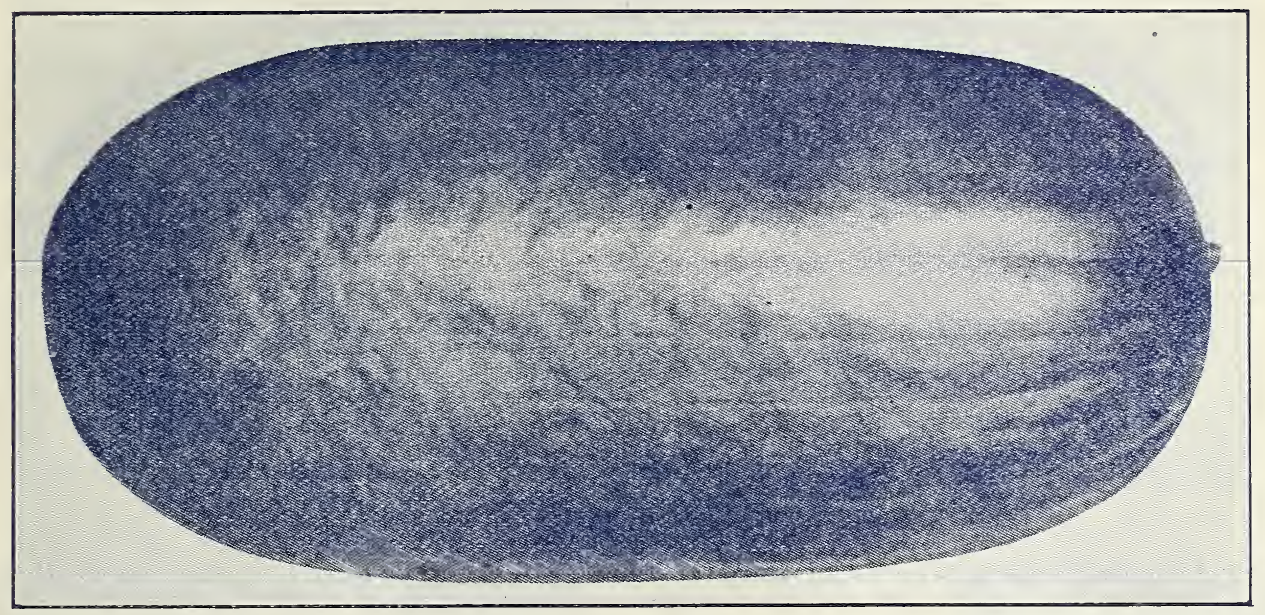

WATSON (TOM WATSON)

Any one who grows watermelons in the South must have selected Southern-grown seed if he expects any results. Western or Northern-grown seed will not do. Think of it, we can buy melon seed in the West at 10c a pound, when we are paying as high as fifty to seventy-five cents for Southerngrown seed of the same sort. There's a reason.

Watson-This variety has just about monopolized the melon markets of the country, owing to its size and quality. We have seen solid car loads average forty-five pounds, and few cars are shipped that do not average more than twenty pounds. In color it is green, mottled with lighter shades; rind thin, but tough; flesh of a peculiar deep but bright red, very sweet. Seed medium size, white and brown. We have choice selected stock to offer. Pkt., 5c; oz., 10c; $1 / 41 \mathrm{~b}$., $25 \mathrm{c} ; 1 \mathrm{~b}$., $75 \mathrm{c}$.

Kleckley Sweet or Monte Cristo-The sweetest melon known. Medium long, skin dark emerald green; rind thin; flesh rich scarlet; seed small and pure white. It is not a good shipping sort, but for home use or local market it is absolutely unequalled in eating qualities. Where it is known in market it will bring more than other sorts. Pkt., 5c; oz., 10c; $1 / 4$ lb., 25́c; 1b., 75c.

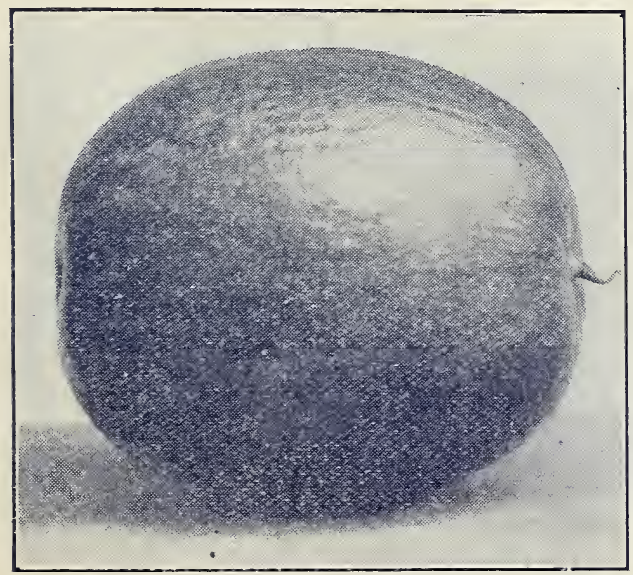

THE TRIUMPH

Florida Favorite-A long dark green sort, mottled and striped; rind thin, but tough, making it a splendid shipping sort. The average size is twenty to thirty pounds. The quality is superb and since the variety is not only early but very prolific, enables it to hold its own. Pkt., 5c; oz., 10c; 1/4 lb., 25c; 1b., 75c.

The Bradford-Here is another superfine melon, shape long, color dark green, underlaid with dark stripes. The flesh is a beautiful red, of fine texture and very sugary. Seed white, blotched with brown. Pkt.,!5c; oz., 15c; 1/4 lb., $40 \mathrm{c}$; lb., $\$ 1.25$.

The Triumph (See Cut)-The illustration shown here gives you an accurate idea of its shape. The rind is dark green, blotched occasionally with lighter shade. It is probably the largest melon grown. Sixty and seventy-five pounders are common, and a hundred is not unusual. It's a fine shipper, early, prolific and brings good returns in some markets. Seed black. Pkt., 5c; oz., 10c; $1 / 4$ lb., 25c; 1b., 75c. 


\section{Watermelons}

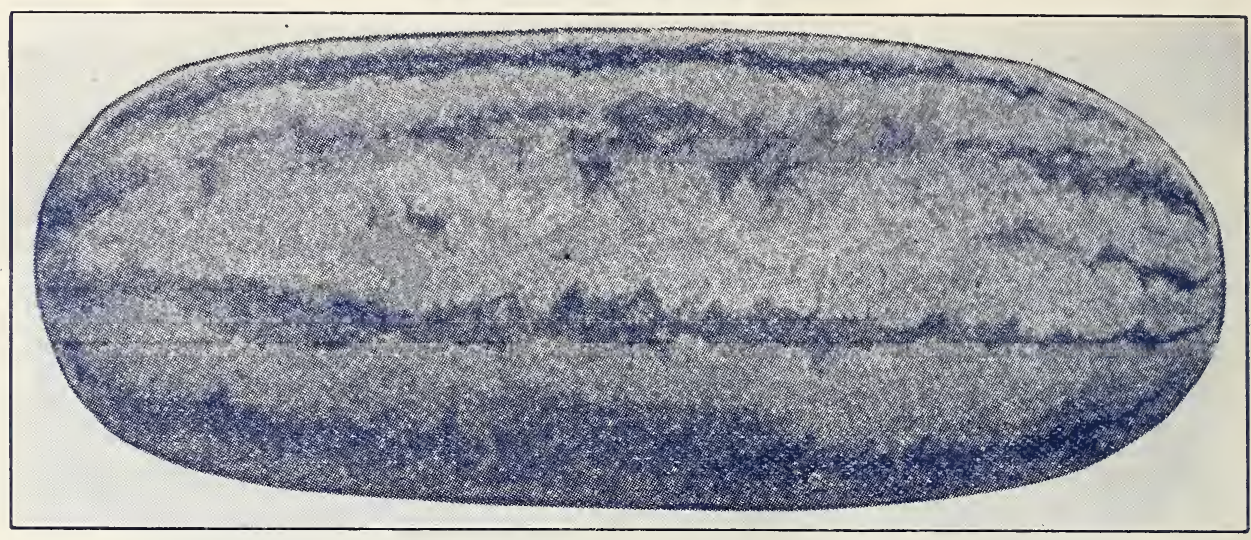

AUGUSTA RATTLESNAKE

Augusta Rattlesnake-This type of rattlesnake is far superior to the ordinary Georgia Rattlesnake. It is much larger, more uniform, and does not run to necks. The flesh is a deep red, brittle sweet and free from strings. The melon is solid and never contains any hollow. The seed are large, white, with a distinct black ring around the edge. Our seed are not mixed in the slightest, being grown on a farm where no other sorts are cultivated. This is one of the earliest of melons, and on account of its uniform large size is most desirable for shipping or home market. Pkt., 5c; oz., 10c; 1/4 lb., 35c; lb., $\$ 1.00$.

Georgia Rattlesnake-A standard variety in the South, a good shipper, and a splendid home melon. The melon is long, distinctly striped with darker shades of green on a light green back ground. The seed are white with black eye and an occasional stripe around the seed. It does not grow as large as the Augusta Rattlesnake, but is a little earlier and more prolific. Pkt., 5c; oz., 10c; 1/4 lb., 25c; 1b., 75c.

Kolbs Gem-A very early and exceedingly prolific variety; rind thick, a splendid keeper, making it a very desirable shipping sort. The fruit is round or oblong; rind green striped with lighter shade; meat firm, although a little coarse; seed black. It will yield a fine crop under very adverse conditions. Pkt., 5c; oz., 10c; 1/4 lb., 25c; 1b., 75c.

Jordan Gray Monarch-This is a very long gray melon of exceptional good quality. The rind is very thin and brittle, making it undesirable for shipping, but for home market or home consumption it has few equals. The flesh is a handsome red, tender and exceedingly sweet; seed small and pure white. Pkt., 5c; oz., 10c; $1 / 4$ lb., 25c; lb., 75c.

The Ivey-This is a very long, greenish gray melon, growing to a very large size, often fifty to seventyfive pounds. The rind is thin but very tough and leathery, making it a most desirable shipping melon; and, owing to its handsome appearance, will always meet with ready sale. In fact, its very appearance will sell it. No one will be disappointed who buys, because it has the quality. The flesh is firm, but very brittle, and is of that shade of red so desirable in a melon. Seed small and of reddish brown color. It is medium late in maturity. Pkt. $5 \mathrm{c}$; oz., $15 \mathrm{c} ; 1 / 4 \mathrm{lb}$., $40 \mathrm{c}$; lb., $\$ 1.25$. 


\section{Mustard}

Mustard is one of the staple vegetables of the South, and there is some doubt if any other one is more universally grown. It is one of the most wholesome, as well as digestible, of any, and it is well known to be a splendid remedy for stomach and intestinal troubles. Liberal eating of mustard greens has been known to cure obstinate cases of constipation, where medicine failed.

It has been discovered in the past few years that the feeding of chickens on ground mustard, or even on the green plant, has a marked influence on egg production, keeping them in good physical condition and induces them to an increased egg production during winter.

Mustard may be planted outdoors most any day of the year, throughout the South. Better results are obtained by planting in drills and cultivated like turnips. One of the best ways to cook mustard is to boil it practically dry and then fry it in a covered skillet, plenty of good bacon, but don't scorch it.

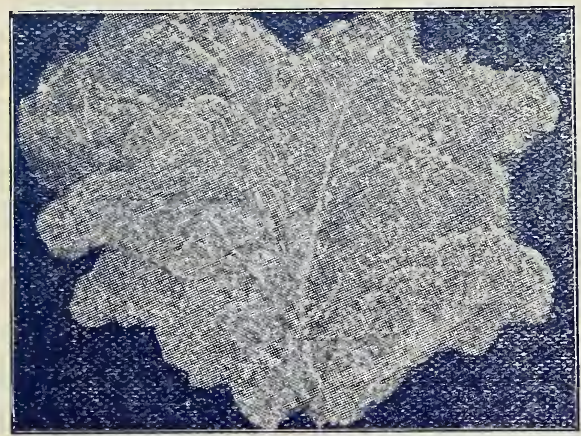

Southern Giant Curled-This is a type of curly leaved mustard that has been developed in the South and will give much better satisfaction than any other curled sort. There are other types possibly more curly, but will not afford half the foliage. It is difficult to keep mustard true, because it has a tendency to degenerate back to the wild, rough, prickly leaved type. Pkt., 5c; oz., 10c; $1 / 4$ lb., 25c; lb., 75c.

Chinese Broad Leaf-This is a type of mustard altogether different from the curled, and is frequently spoken of as cabbage leaved mustard. The variety produces a very large broad, thick leaf, almost smooth and slightly resembles a cabbage leaf. It is extremely hardy, finely flavored, and is long about going to seed. Pkt., 5c; oz., 10c; $1 / 4$ lb., 35c; lb., $\$ 1.00$.

\section{Okra (Gumbo)}

Gumbo-This is another staple vegetable in the South, grown almost universally and very highly prized. It is also another vegetable of great health giving qualities, being very digestible and nutritious. The okra plant belongs to the cotton family, is planted at the same time, cultivated alike and has practically the same bearing period. Any soil that will grow good cotton will make okra, and the same fertilizer will answer for both, only it will be desirable to fertilize okra somewhat heavier. Okra may be planted from latter part of February to June, the earlier the better if the soil gets warm enough, but it's a hot weather plant, and if soil is cold seed won't germinate. The seed should be drilled thickly in rows when the soil gets warm and the rows should be three to four feet apart, and if you get a thick stand the plants should be thinned to two to three feet apart, to get the best yield. Most every one makes the mistake of growing okra too thick. In growing on a large scale, it is desirable to check the crop three feet or more each way. Deep cultivation at first, but when it commences to bear shallow cultivation. Remove all pods before they get hard, whether wanted for use or not.

White Velvet-This type of okra is different from any other in that its pods are round, very smooth and of a whitish light green color, covered with a fine fuzz, resembling velvet. The pods, when fully ripe, will often measure a foot long. This variety remains in edible condition, without getting tough and stringy, longer than any other sort. The seed of this sort are hard to gather, owing to the fact that the pods do not crack; in fact, the seed must be shucked out. Pkt., 5c; oz., 10c; $1 / 4$ lb., 20c; 1b., 50c.

Long Green or Tall-This is a tall, late variety, growing sometimes eight to twelve feet high, bearing until winter, very long dark green pods, which are heavily ribbed or ridged. The pods, when not too old, are very tender and exceptionably good flavor. Pkt., 5c; oz., $10 \mathrm{c} ; 1 / 4$ lb., 20c; 1b., 50c.

Dwarf Green Prolific-A very early prolific type, producing short dark green pods, ribbed or ridged. The plant will commence to bloom and fruit when about six to eight inches high and continue throughout the summer. The matured height of the plant is generally from four to four and a half feet, depending much, of course, on the fertility of the soil. Pkt.,5c; oz., 10c; $1 / 4$ lb., 20c; 1b., 50c.

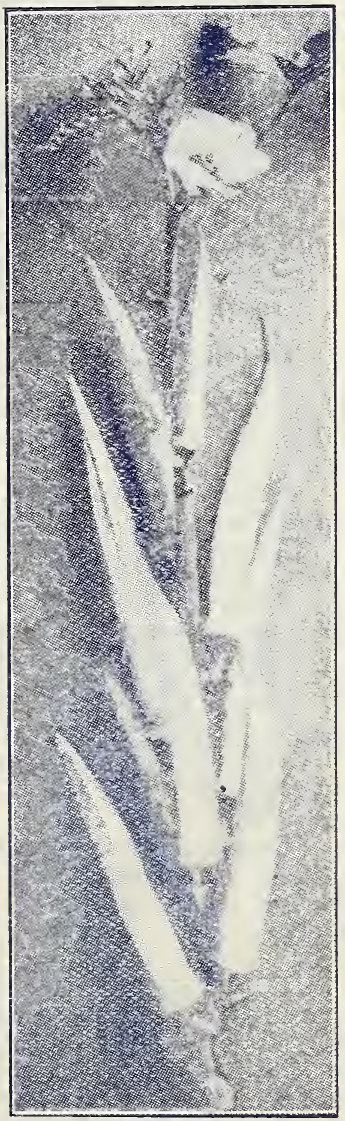

OKRA WHITE VELVET

Perkins Mammoth Long Pod-An early prolific type, growing three to four feet high and producing long, slender deep green pods, slightly ridged or corrugated, and of splendid quality. It is largely grown in the South by market gardeners for shipping. Pkt., 5c; oz., 10c; 1/4 1b., 20c; lb., 50c. 


\section{THE PLAIN TRUTH ABOUT SEED MEVAY SEED AND FLORAL COMPANY

\section{Onions}

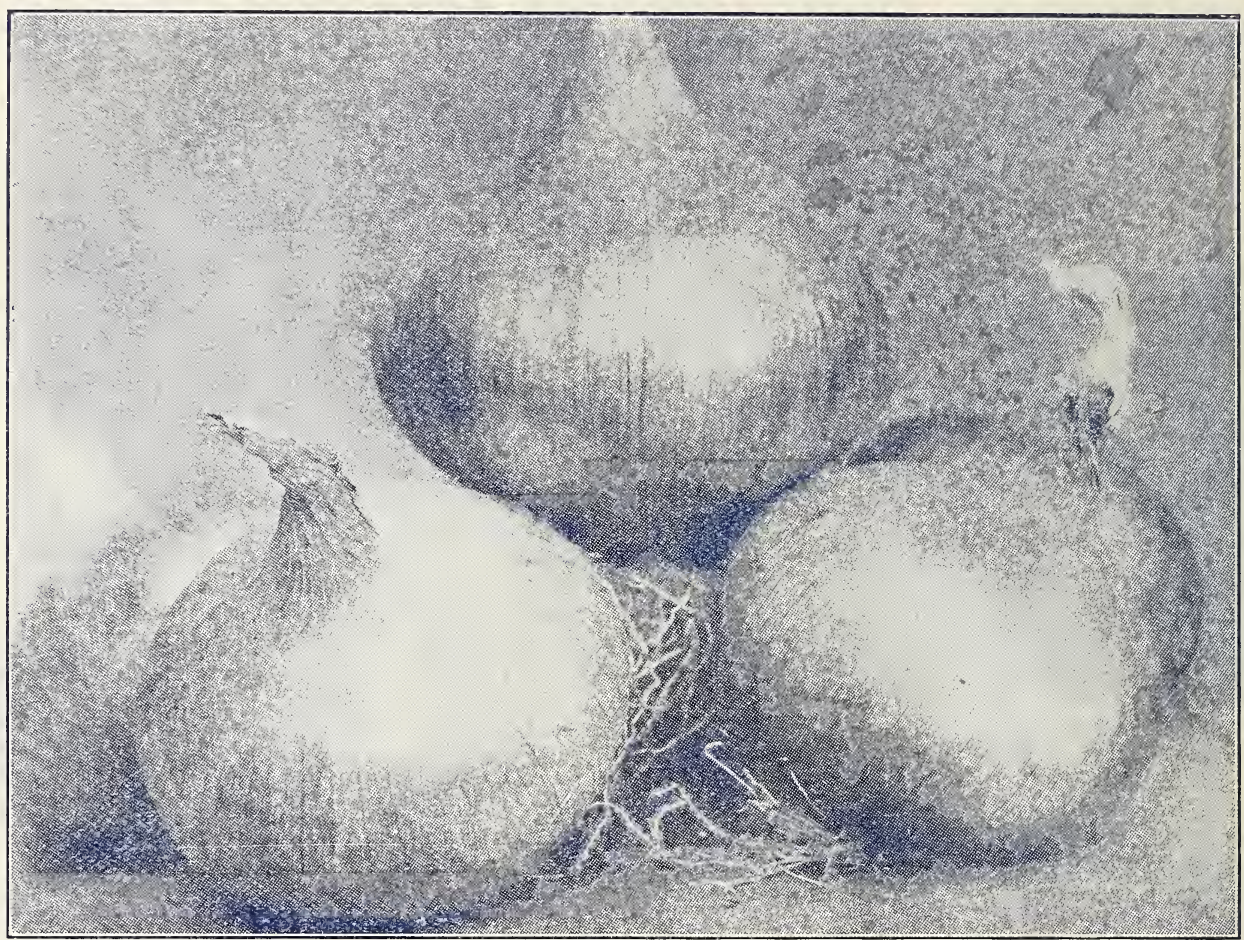

5. Onions From Seed-For early spring onions sow seed in protected beds, cold frames or hotbeds, in October, November, or December; transplant to open ground in January, February weather permitting. For summer or early fall crop of green or dry onions, plant seed thinly in drills February or March and thin out to proper distance; transplant your thinings to other rows. Fertilize highly and cultivate well.

Red Wethersfield-A deep purplish red, good keeper and of splendid quality. It is rather a late sort but with proper culture will mature from seed all right. Pkt., $5 \mathrm{c} ; \mathrm{oz} ., 15 \mathrm{c} ; 1 / 4 \mathrm{lb} ., 50 \mathrm{c} ; 1 \mathrm{~b} ., \$ 1.50$.

Yellow Globe Danvers-An early yellow variety of handsome appearance, a good keeper and a heavy yielder. Pkt., $5 \mathrm{c}$; oz., $15 \mathrm{c} ; 1 / 4 \mathrm{lb} ., 50 \mathrm{c} ; \mathrm{lb} ., \$ 1.75$.

Prize Taker-This is the largest type of yellow onion, very early. Shape round or globe, mild and juicy, and a splendid keeper. Pkt., 5c; oz., 15c; 1/4 lb., 50c; lb., $\$ 1.75$.

Mammoth Silver King-A very large, early white onion, flat to oval shape, mild and agreeable flavor. Pkt., 5c; oz., 15c; $1 / 4$ lb., 50c; lb., $\$ 1.75$.

White Bermuda - This is a very early imported variety. Outer skin a pale yellow, size medium, shape flat, no necks, flavor very mild. A great yielder. Pkt., 5c; oz., 20c.

Should only be planted in fall and transplanted later. Write for prices.

Red Bermuda-The same as White Bermuda, only the outer skin is a slight purplish red. Pkt., $5 \mathrm{c} ; \mathrm{oz} ., 20 \mathrm{c}$.

Crystal White Wax Bermuda-This is the true White Bermuda, the earliest type and most saleable. It is widely known as the Texas Onion, as millions of dollars worth are grown in that State. The seed should be sown in October and November, to transplant in January or February. Pkt., 5c; oz., 25c.

\section{Onion Sets}

We can supply Red, White, and Yellow Sets every month in the year except a short period in June and July. The set is the proper thing for the home gardener to buy, because most of the onions are pulled up and eaten green.

We do not guarantee prices on sets. Write for special prices.

White Silverskin-Pt., 10c; qt., $15 \mathrm{c} ; 1 / 2$ pk., $50 \mathrm{c}$; pk., $85 \mathrm{c}$.

Yellow Danvers-Qt., 10c; $1 / 2$ pk., $40 \mathrm{c}$; pk., $75 \mathrm{c}$.

Dark Red-Pt., 10c; qt., 15c; 1/2 pk., 40c; pk., 75c.

If sets are ordered by mail, add $10 \mathrm{c}$ per quart for postage. 


\section{Parsley}

Every one should have his parsley bed, because even a space three by four feet will furnish a good size family with all they need, and practically all the year round. The plant is extremely hardy and, with only slight protection, will carry through severe winters. Plant in a protected place, or throw a little straw or litter over it during severe weather, is sufficient protection. It is frequently grown in large flower pots or fern pans, not only for ornament but for flavoring soups or garnishing dishes or for mixed salads. The plant possesses great medical properties and is altogether very healthful.

The seed may be sown in drills in very early spring or in early fall of the year. Ground should be exceedingly rich, very deep and loose. Plants should be thinned to four or six inches apart and the ground kept well stirred around the roots. The seed is very hard to germinate, and should be soaked a day or two before planting.

Champion Moss Curled-The finest Parsley in texture grown, of very best flavor, hardy, of fine appearance, exceedingly curled, and without doubt the most saleable sort on the market. Pkt., 5c; oz., 15c; $1 / 4$ lb., 40c; lb., $\$ 1.25$.

Smooth Leaf or Plain-A variety possessing all the merits of Moss Curled, only its leaves are plain or smooth, much preferred by some on account of ranker foliage. Pkt., 5c; oz., 15c; 1/4 lb., 40c; lb., \$1.25.

Large Double Curled-This is an ex cellent variety, dwarf in habit, grows very compactly, and stands the winter better than the plain. It produces beautifully crimpled leaves, which are superior to all as a seasoner. Pkt., 5c; oz., 15c; 1/4 lb., 40c; lb., \$1.25

Market Garden-This is an early branching, beautifully curled sort, in great

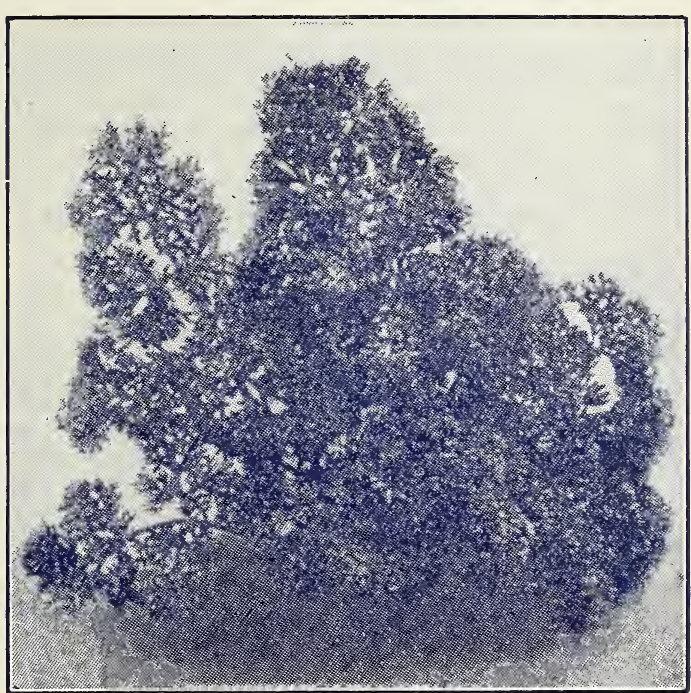

MARKET. GARDEN

demand with market gardeners because of the amount of foliage it makes and the fact that it grows more upright and not so dwarf as some and more easily bunched for market. In flavor, as well as hardiness, it is as good as any. Pkt., 5c; oz., 15c; $1 / 4 \mathrm{lb}$., 40c; lb., $\$ 1.25$.

\section{Parsnips}

How to Grow-One experiences the greatest trouble in getting Parsnips to vegetate. The seed is very light and naturally slow to sprout, even under the most favorable circumstances, but if you

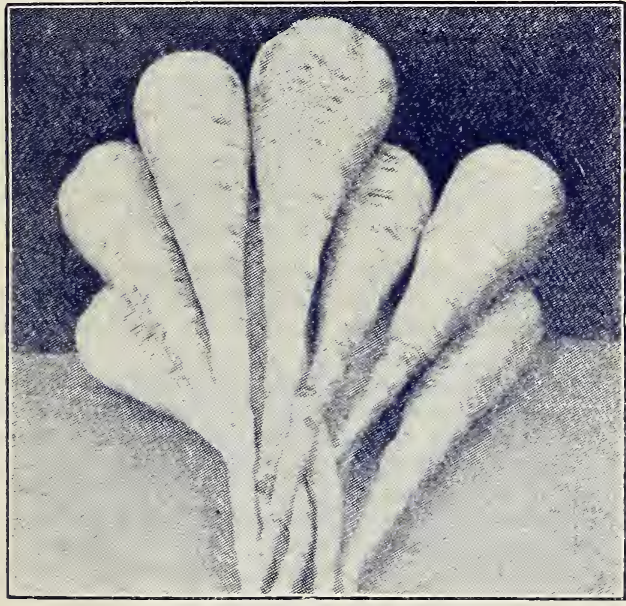

SUGAR OR HOLLOW CROWN will be patient they will generally come. They succeed best in deep, rich, sandy loam. Sow early in the spring or in the early fall in drills eighteen to thirty inches apart. Scatter the seed thickly and cover evenly with a rake, and be sure to have your ground well pulverized. After the plants come up they should be well cultivated until the foliage covers the ground. But first thin to about four or five inches apart.

The Best Fertilizer-It requires good strong soil to produce the Parsnip to perfection. They extract a great deal of potash from the soil, and should be fertilized with a fertilizer rich in potash. This may be prepared by the farmer, using two hundred pounds each of kainit, cotton seed meal and acid phosphate, mixed well, broadcasted to the acre.

Sugar or Hollow Crown (See Cut)-It is the standard variety for either table use or stock feeding. It produces long, smooth, roots, which are very tender and sugary and of delicious flavor. Pkt., 5c; oz., $10 \mathrm{c} ; 1 / 4 \mathrm{lb}$., 25 c; lb., 75 c. 


\section{Garden or English Peas}

One quart to one hundred feet drill; two bushels to acre.

Peas, with the growers, are short crop this season. Prices have advanced rapidly in the past few weeks. We find ourselves compelled to advance our prices. But we know our prices are as low as any house in the country, considering the excellent quality that we offer.

Peas may be planted in most parts of the South from January 1 to September 15. Two to three bushels are required to the acre. The smooth varieties are the hardiest, and should be planted first. The seed are usually sown thickly in double rows, and these double rows, constituting one row, should be about three and a half to four feet apart. Cover seed two to three inches, and if too thick, thin to about an inch and half to two inches. Cultivate often, especially in dry weather. A thick stand is desirable. It is not necessary to provide supports for the dwarf sorts. Peas grow fairly well on poor soils, but a little fertilizer will greatly increase the yield. Well rotted stable manure in the drill is splendid, but fresh manure should be avoided unless it is broadcasted. Commercial fertilizer is desirable. When it is used it should be incorporated thoroughly with the soil.

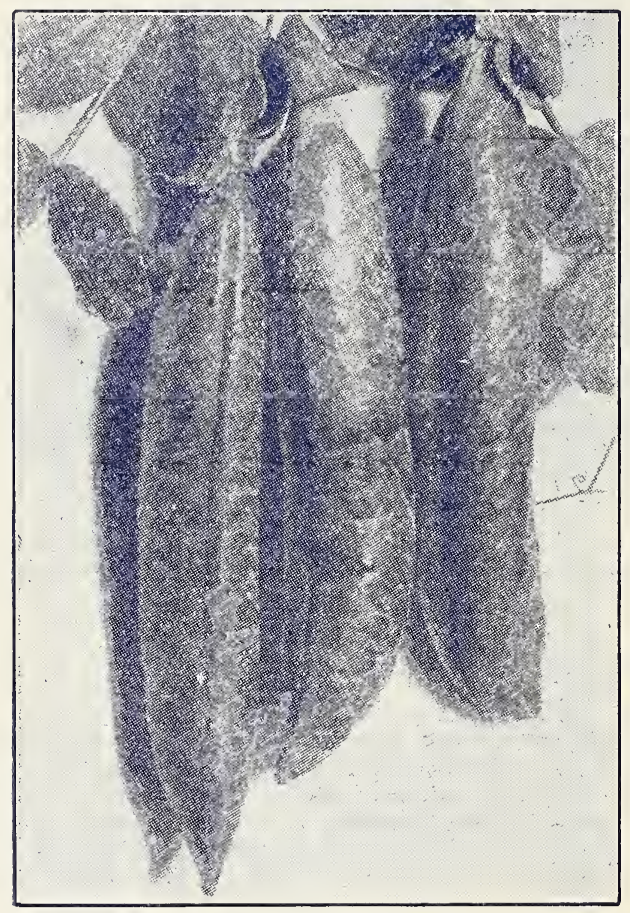

ECLIPSE

\section{Wrinkled Varieties}

Eclipse-A hardy wrinkled imported variety of English Pea, growing about two feet high, producing a heavy vine and standing up well without supports. The pod is dark green, from three to three and a half inches long, and loaded with peas of excellent sweet quality. The variety is a hardy germinator, not so delicate as the average wrinkled sort, will stand a great deal of cold and heat, and can be planted earlier or later than most any other sort. In point of earliness it is about as early as the earliest extra early, but is decidedly more prolific and bearing period much longer. Pt., 20c; qt., 35c; pk., $\$ 2.00$. By mail, postpaid, pt., 30c; qt., 50c.

Gradus or Prosperity-The pods are immense, containing very large peas of the finest flavor; growth vigorous; about 30 inches high; does not require staking; bears very early, just a few days after Alaska, and continues through a very long season. We highly recommend this sort. Pt., 25c; qt., 40 c; pk., $\$ 2.25$; bu. $\$ 8.00$. By mail, postpaid, pt., $35 \mathrm{c}$; qt., $55 \mathrm{c}$.

Champion of England-This is the most popular wrinkled variety grown, and the largest and most productive. It will, under favorable conditions, attain a height of eight to twelve feet or more. Pt., 15c; qt., 25c; pk., $\$ 1.50$; bu., $\$ 5.50$. By mail, postpaid, pt., 25c; qt., $40 \mathrm{c}$.

Eugenia or Alliance-It is of an exceedingly delicious flavor, very sugary and sweet. It bears for a long time, making it a very profitable variety. Pt., 20c; qt., 35c; pk., $\$ 2.00$; bu., $\$ 7.50$. By mail, postpaid, pt., 30c; qt., $50 \mathrm{c}$.

Bliss Everbearing - This is a new second early variety, about ten days later than the American Wonder, bearing large, well-filled pods, containing about seven or eight peas each. The pea is of dwarf habits, growing from 15 to 20 inches in height. Pt., 20c; qt., 35c; pk., \$1.75; bu., \$6.50. By mail, postpaid, pt., $30 \mathrm{c} ; \mathrm{qt} ., 50 \mathrm{c}$.

American Wonder-It is of the most excellent flavor, exceedingly productive, and as early as McLean's Little Gem. It is an exceedingly dwarf variety, seldom ever attaining over a foot in height, and can be planted very close together. Pt., 20c; qt., 35c; pk., $\$ 2.00 ;$ bu., $\$ 7.00$. By mail, postpaid, pt., 25c; qt., $40 \mathrm{c}$.

Telephone Pea-This is a very tall, wrinkled variety, a strong grower, and enormously productive. The pods are very large, containing from six to nine large peas, which are very sugary and of the most delicate flavor. It makes a very vigorous vine, five to six feet tall, and for productiveness cannot be excelled. Pt., 20c; qt., 35c; pk., \$1.75; bu. \$6.50. By mail, postpaid, pt., 30c; qt., 50c.

McLean's Little Gem-This is one of the earliest wrinkled varieties, and is very prolific and of superior flavor; height one to one and a half feet. It matures in about seven weeks from germination. Pt., 20c; qt., 35c; pk., $\$ 1.50$; bu., $\$ 5.50$. By mail, postpaid, pt., 30c; qt., 50c.

Nott's Excelsior-An extra early variety, very close behind the American Wonder, producing pods a third larger. Pt., 20c; qt., $35 \mathrm{c}$; pk., $\$ 1.75$; bu., $\$ 6.50$. By mail, postpaid, pt., 30c; qt., 50c. 


\section{Garden Peas-Not Wrinkled}

This type of English Pea is known as ${ }^{-}$llick $^{7}$ or hard varieties. They are much heavier yielders than the wrinkled or sugar sorts, more hardy and may be planted a great deal earlier. These varieties are grown more largely in the South than wrinkled sorts, because they can be gotten in early when the soil is cold and germinate when wrinkled sorts would not come up but rot in the soil. But if one can wait until the soil is warm, we advise the planting of wrinkled sorts because there is no comparison in the quality. The slick sorts become tough and tasteless right away, while the wrinkled sorts are sugary and sweet until pod begins to die.

The tall sorts are much more desirable if one can provide supports, bearing longer and yielding larger pods.

Mammoth Podded Alaska-This is a very early variety, growing about two feet high and producing an enormous crop of dark green pods, like the regular Alaska only much larger. The variety is uniform and fills out well and really contains some peas. The housewife does not have to shell a half bushel of pods to get enough for dinner. Pt., 20c; qt., 35c; pk., $\$ 1.50$; bu., $\$$ J.50. By mail, postpaid, pt., 3Jc; qt., 50c.

First and Best - This celebrated extra early variety is without an equal in general popularity, being early, hardy and a most prolific bearer. It is of uniform growth, about two feet high, stalks very bushy, standing well and holding its fruit well above the ground. Our stock is very fine this season, extra selected, and cannot be too highly recommended. Pt., 15c; qt., 25c; pk., \$1.25; bu., $\$ 5.50$. By mail, postpaid, pt., $25 \mathrm{c}$; qt., $40 \mathrm{c}$.

Tall White Marrowfat-A very tall, vigorous growing sort, exceedingly prolific, pods very large, of good quality, and bearing until frost. The variety is very hardy, standing more heat and cold than any other sort; fine for the market gardener. Pt., 10c; qt., 20c; pk., $\$ 1.25$; bu., $\$ 4.50$. Postpaid, pt., 20c; qt., 35c.

Black Eyed Marrowfat-This is the most popular of all the Marrowfat varieties, being more productive and hardier. It is a very strong, vigorous grower, and will bear for a long time. It is largely planted by Birmingham gardeners for their general crop. Pt., 10c; qt., 20c; pk., $\$ 1.25$; bu., $\$ 4.50$. By mail, postpaid, pt., 20c; qt., 35c.

Early May Pea-This is a famous second early variety, is medium tall in growth, exceedingly productive, and of delicious flavor. It is very hardy, a vigorous germinator, and deserves to be

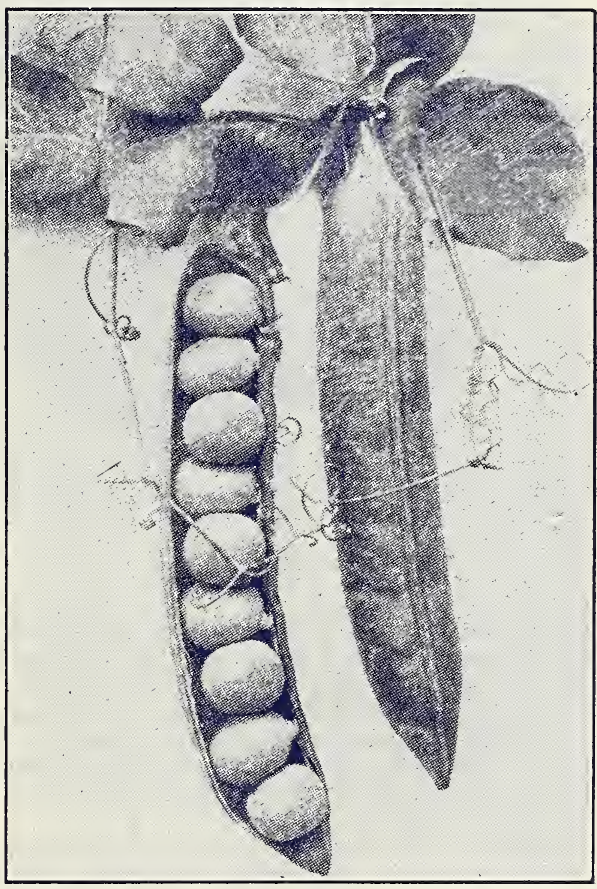

MAMMOTH PODDED ALASKA largely cultivated. Pt., 15c; qt., 25c; pk., $\$ 1.25$; bu., $\$ 5.50$. By mail, postpaid, pt., 25c; qt., 40c.

Tom Thumb-An extra early, very dwarf variety, growing about ten to twelve inches high, very popular on account of its stocky and dwarf growth, but it is not of the best quality. Pt., 20c; qt., 35c; pk., $\$ 2.00$; bu., $\$ 7.50$. ¿ By mail, postpaid, pt., 30c; qt., 50c.

Melting Sugar or Salad Pea-A good sort, early prolific and very sweet. The seed is round, slightly wrinkled, and hardy of germination. Pt., 25c; qt., 40c; pk., $\$ 2.50$; bu., $\$ 8.00$. By mail, postpaid, pt., 35c; qt., 55c.

Alaska-One of the finest extra early peas grown; extremely early, very hardy, and a most prolific sort. The variety is very distinct from anything else, the dry peas being of bright green color, as are also the vines and pods, and will carry farther without injuring their bright green color than any other sort. Our stock is genuine-obtained direct from the grower, and introducer. Pt., 15 c; qt., 25c; pk., $\$ 1.25$; bu., $\$ 4,75$. By mail, postpaid, pt., 25 c; qt., 40 c.

Early Morning Star-This famous variety is, without a single exception, the earliest pea in the world. It is one of the most productive as well as the earliest pea grown. It never fails to produce marketable peas in 42 days from germination. Pt., 15c; qt., 25c; pk., $\$ 1.50$; bu., $\$ 5.50$. By mail, postpaid, pt., $25 \mathrm{c}$; qt., $40 \mathrm{c}$. 


\section{Pepper}

How to Grow-If you want to succeed well with pepper, cultivate it regularly from the time the plants come up until the late fall frost comes. It will bear as long as you cultivate it until killed by frost. Pepper delights in very rich, loose soil, and requires that it be very strong to perfect its growth.

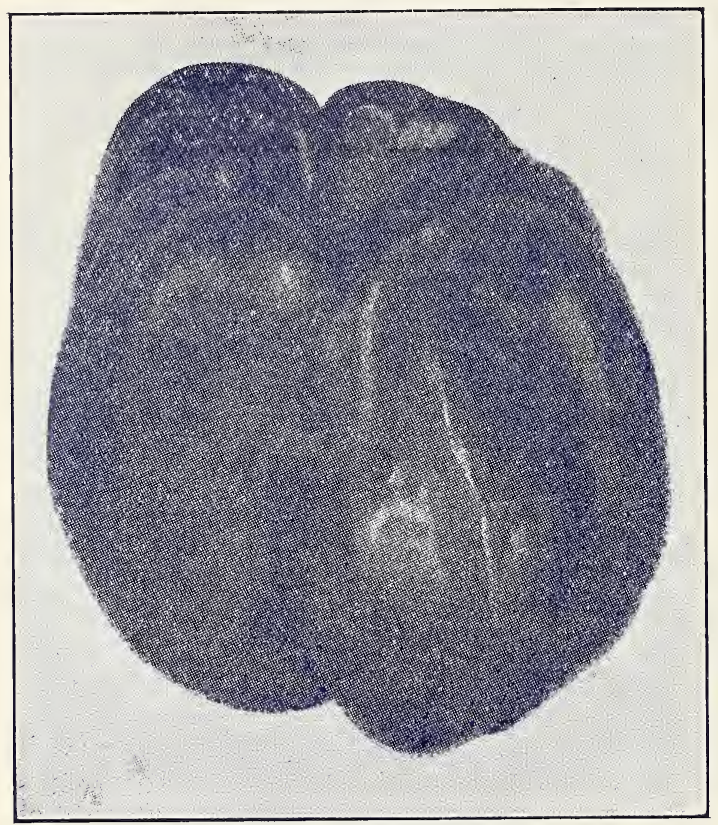

CHINESE GIANT

It may be sown in winter or very early spring on a hot-bed, the same as for egg plant, and let it remain until the weather becomes warm, and transplant in drills a foot apart and rows eighteen inches distant.

Chinese Giant-This is a true sweet pepper and the very largest in cultivation. The plant is a vigorous grower, very prolific, has a long bearing period for sweet sorts and produces practically all of its fruit uniform in shape and of immense size. It is in great favor with the professional truckers who grow for shipping. The flesh is sweet, tender and of delightful flavor. For salads, mangoes or stuffing it has no equal. The skin is a rich green, when ripe a brilliant red. Pkt., $5 c$; oz., 35c; $1 / 4$ lb., $\$ 1.00$; lb., $\$ 3.50$.

Ruby King - This is an enormous large variety, growing from four and a half to six inches long and three to four inches thick. The flesh is very thick, tender, mild and pleasant to the taste. It is a fine sort for stuffing or for pepper hash. and also makes an elegant dish of salad. The growth of its foliage is very distinct, being large-leaved and vigorous. Pkt., 5 c; oz., 25c; $1 / 4$ lb., 75c; lb., $\$ 2.50$.

Large Bell or Bull Nose-Our stock of this well known variety, sometimes called Sweet Mountain, is very superior. Plant vigorous, about two feet high, compact and very productive, ripening its crop uniformly and early. The fruits are large, with thick, mild flesh of excellent quality for use in salads and mangoes or stuffed peppers. The color is deep green when fruit is young, bright crimson when ripe. Pkt., 5c; oz., 20c; $1 / 4$ lb., 65c; lb., $\$ 2.00$.

Large Sweet Spanish-A late maturing and attractive red, sweet pepper. Plant about two and one-half feet high, upright, very compact, vigorous and productive. Fruits very large and long, frequently seven inches in length and about two inches in diameter, with very thick, mild flesh of excellent quality. Color deep green when fruit is young, rich red when ripe. Pkt., 5c; oz., 20c; $1 / 4$ lb., 65c; lb., $\$ 2.00$.

Red Cherry-A small, vigorous growing sort, will commence bearing when plants are six inches high, and will continue growing and bearing until killed by frost. The pods are small, round and very hot. Pkt., 5c; oz., 20c; $1 / 4$ lb., 65c; lb., $\$ 2.25$.

Red Chili-A very hot, piquant sort, very prolific. The plants commence to bear by the time they are four or five inches high, and when frost comes in the fall will still be full of green pods if kept picked during summer. It is largely used in making pepper sauce, and possesses the best flavor of any sort. The plants are often grown in flower pots, making a beautiful show. Pkt., 5c; oz., 25c; $1 / 4$ lb., 75c; lb., $\$ 2.50$.

Long Red Cayenne-This is a fine, large variety, very hot, and of exceedingly delicate flavor as a seasoner. A single stalk will often produce enough for an ordinary family. It is a good keeper. When fully ripe can be gathered, dried and strung for winter use. Pkt., 5c; oz., 20c; 1/4 lb., 65c; lb., $\$ 2.25$.

Tobasco-This is a red, hot variety, and the best flavored sort of any. The plants commence to bear when very small, producing pods one to one and a half inches long, and will continue to grow, spread out until one to two feet high, and bear on until killed by frost. A single plant, if kept well picked, will often yield in a season five hundred to a thousand pods. For making pepper sauce and for stringing and drying for winter use it is exceptionally good. Pkt., 5c; oz., 25c; $1 / 4$ lb., 75 c.; lb., $\$ 2.50$.

\section{Pepper Plants}

In season, commencing April, we can suppy our customers pepper plants of our leading sorts at $25 \mathrm{c}$ per dozen; this is for good strong plants that have been transplanted for at least one time. We supply, in season, also such plants as cabbage, tomato and egg plant. 


\section{Seed Potatoes}

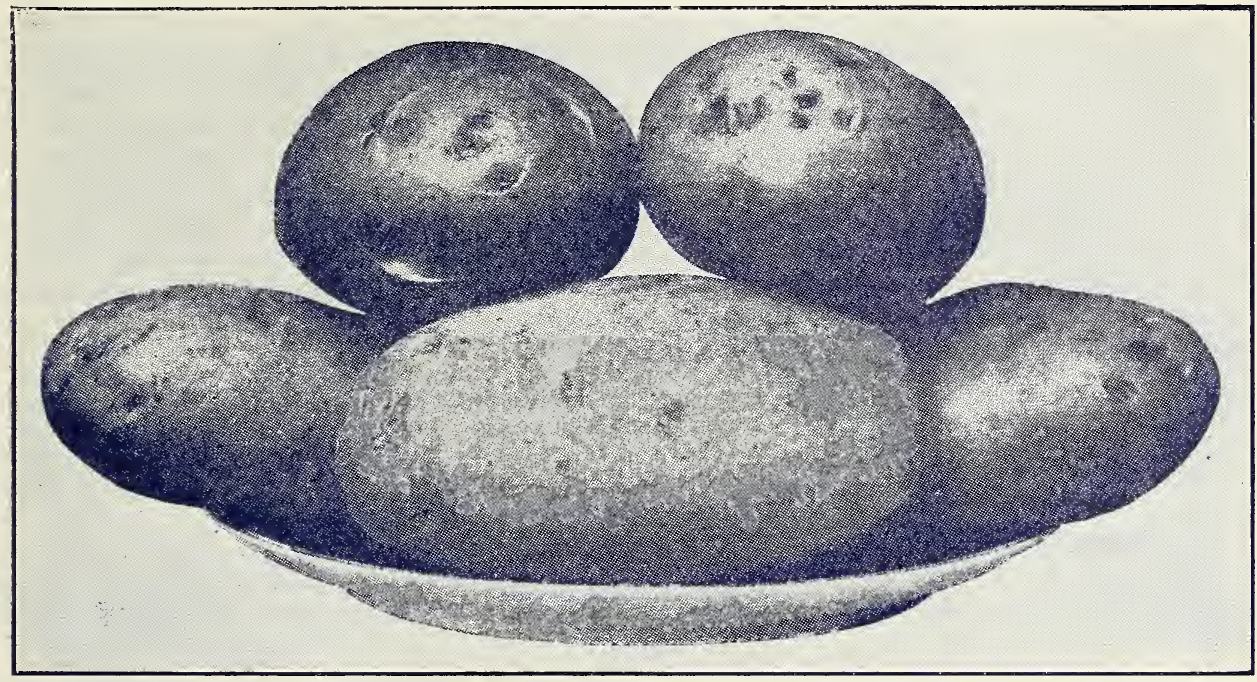

How to Grow-Most every farmer has his own pet way of growing a crop of potatoes, which he believes is superior to any way that might be suggested. But the best of them sometimes make error in method of preprartion and fertilization. All potato ground should be very deeply broken, and preferably in the fall of the year. It will be advantageous to sow potato ground in early fall of the year in vetch, crimson clover or a mixture of both, or rye-anything to produce vegetable matter. This should be turned under in January and allowed to remain until the time has arrived for planting. Rows should then be laid off from three to three and a half feet. The fertilizer that is to be used should then be placed in the drill and a small subsoil plow run in each drill, which will stir the ground to a greater depth and mix the fertilizer with the soil in the bottom of the furrow. The cuttings should then be dropped and covered with a turning plow to the depth of eight to ten inches. They should then remain until they begin to sprout nicely, and then a leveling harrow should be drug over the entire field. This harrowing should continue until the vines are about four to six inches high, then the first cultivation may be given them. If ground be properly prepared to begin with, very little cultivation is necessary to make a crop of potatoes, the harrow doing most of the work. The three most essential features in growing potatoes are deep preparations, deep plantings, and thorough cultivation and fertilization.

Caution-Potatoes will not make deep in the soil. The ridges should be harrowed off so the cutting will not be over three to five inches deep.

Irish Cobbler - This potato is fairly taking the South and in a great measure supplanting all others. It is extremely early, probably as early as the Triumph, and certainly not more than a week behind, and for quality is far ahead. The Cobbler is a pure white variety, mostly round; eyes plentiful and usually deep set. It grows uniform to a large size and bears very few small tubers. It cooks splendid any way; never gummy but mealy, and of a delightful flavor. The stock we supply is generally the fall grown or second crop and, while smaller, is generally more desirable than spring grown stock. The Cobbler being a splendid yielder, showy and of excellent quality, makes it desirable not only for market but for home use as well. $1 / 2$ pk., $30 \mathrm{c}$; pk., $50 \mathrm{c}$; bu., $\$ 1.75$. Write for prices in quantity.

Tennessee Triumph (Fall or Second Crop) - The well known round, red potato. It is the earliest type and more largely grown in the South than any other sort. It makes a small vine and resists drouth better than any other sort. It should be highly fertilized, otherwise there will be too many small potatoes. While the planting seed is small, we recommend the Tennessee grown as they always come up to a good stand and require much less to plant an acre. $1 / 2 \mathrm{pk}$., $30 \mathrm{c} ; \mathrm{pk}$., $50 \mathrm{c} ;$ bu., $\$ 1.75$. Write for prices in quantity.

Peerless - An old standard variety of exceptionable quality. The outer skin is white or nearly so; shape round to oblong, and grows uniformly large. It is a medium early sort, prolific, a good keeper, showy and altogether a very fine market variety, as well as most desirable for home use. $1 / 2 \mathrm{pk}$., 30 c; pk., $50 \mathrm{c}$; bu., $\$ 1.75$. Write for prices in quantity.

Early Rose-An early sort of great merit as to quality. It is not much grown for market, because not a heavy yielder. The potato is generally uniform and of good size. Where earliness and quality is desired, it is hard to beat. $1 / 2$ pk., $30 \mathrm{c}$; pk., $50 \mathrm{c}$; bu., $\$ 1.75$.

Burbank-A late maturing variety, very long, extra large, prolific; the best keeper and of splendid quality. It is a good idea to plant Burbank along with early sorts as they will begin to come in after earlier sorts are played out. $1 / 2 \mathrm{pk}$., $30 \mathrm{c}$; pk., $50 \mathrm{c}$; bu., $\$ 1.75$. Write for price in quantity. 


\section{Pumpkin}

It is positively astonishing, the small extent to which pumpkins are grown in the South. So few realize their great value, assuming that there is no sale for them. If you live near a city just try it. and you will be amazed at the demand. The profit will beat watermelons all to pieces. Just try to buy a pumpkin in the city of Birmingham. You can walk your legs off, but wont find any except very rarely, and then you pay twenty-five cents for one about the size of your head. Pumpkins can be planted in corn and take care of themselves without any cultivation whatever, so there is no expense to the crop. The time to plant pumpkins in corn is when the corn is about two feet high. This will give the pumpkins two workings or more before corn is finished. They should be thinned to one vine and no closer than fifteen feet.

How to Grow-Pumpkins succeed best in rich, deep subsoil bottom land, and it is useless to try to produce them on very poor land unless you use considerable fertilizer. The seed may be planted most any time in the spring and summer. They stand the hot sun well on deep soil, necessarily so, as it requires a long time to attain their growth. The crop may be gathered in the fall and stored in a dry place where they will not freeze, and after they have been put away for awhile become very sugary and sweet and a most valuable food for man and beast.

The Best Fertilizer-Potash is one of the most essential things to produce the pumpkin, and if you will only try it you will be surprised at the size they will attain. Mix about 200 pounds of kainit or muriate of potash with a ton of stable manure or scrapings from your lot and apply a shovelful to each hill.

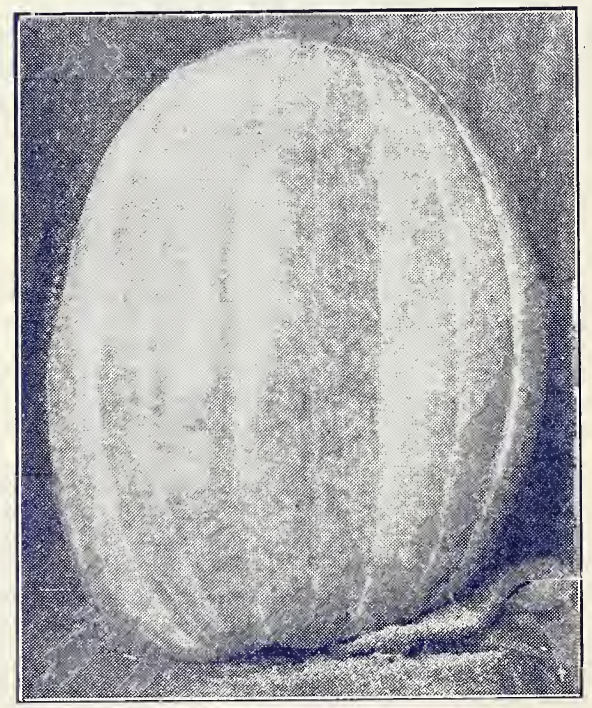

KING OF MAMMOTH

King of Mammoth-This is the largest pumpkin in cultivation and those who want size for exhibition purposes should select this sort. It is no trick to grow this variety to weight a hundred pounds, and it has been produced under irrigation to weigh over two hundred pounds. Of course, plants must be highly fertilized and almost continually worked to produce such sizes. The outer skin is a dull grayish yellow color; flesh light yellow, coarse and somewhat stringy. It is not good to eat except for stock, but it is a splendid keeper and fine feed for cattle and hogs in winter. The seed are unusually large. Pkt., $5 \mathrm{c} ;$ oz., $15 \mathrm{c} ; 1 / 4$ lb., 40c; lb., $\$ 1.25 . j$

Green Striped Cushaw-A pumpkin of specially good eating qualities. It grows a crook neck; skin green and white striped; flesh solid, thick, fine grained, very sweet and of a deep rich yellow color. The variety is enormously prolific, a splendid keeper, and very desirable for market, stock or for home consumption. Pkt. ,5c; oz.,. 10c; 1/4 lb., 35c; lb., $\$ 1.00$.

Yellow Cushaw-The old standard yellow crook neck pumpkin, very hardy, prolific, a good keeper, and very desirable for pies or for stock. Pkt., $5 \mathrm{c}$; oz., $10 \mathrm{c} ; 1 / 4 \mathrm{lb} ., 35 \mathrm{c} ; \mathrm{lb} ., \$ 1.00$.

Kentucky Field-A hardy, very prolific sort of splendid quality, good keeper, prolific and largely used for man and beast. It is mostly round in shape to oval and flattened at the ends; skin creamy yellow;

flesh thick, yellow and sweet. Pkt., 5c; oz., 10c; 1/4 lb., 20c; lb., 60c.

Tennessee Sweet Potato-A medium size pumpkin, bell shaped to round or oblong; skin creamy white, with stripes of light green; flesh white, thick, fine grained, very sweet and especially desirable for pies and custards. Pkt., 5c; oz., 10c; $1 / 4 \mathrm{lb} ., 25 \mathrm{c} ; \mathrm{lb} ., 75 \mathrm{c}$.

Large Sweet Cheese-This is one of the best varieties for family use. It has large, round, flattened fruits, with a creamy buff skin, averaging 20 inches to 2 feet in diameter. It is an excellent keeper, with thick flesh of fine quality. Pkt., 5c; oz., 10c; $1 / 4 \mathrm{lb} ., 20 \mathrm{c} ; 1 \mathrm{~b} ., 60 \mathrm{c}$.

Connecticut Field-Very productive; grown largely.for feeding stock. By mail, postpaid, pkt., 5c; oz., 10c; $1 / 4$ lb., 20c; 1b., 50c. 


\section{Radish}

Parties wanting to buy large quantities of radish to grow for market should write for special prices

Scarlet Turnip - Very early,bright scarlet color all over, good size and standard sort for private gardens. Pkt., 5c; oz., 10c; $1 / 4$ lb., 25c; lb., 75c.

White Tipped Turnip-Very early, small top, fruit scarlet, tipped with pure white. Pkt., 5c; oz., .10c; $1 / 4$ lb., 25c; lb., 75c.

Early Long Scarlet Short Top -One of the best radishes on the list, very early, attaining large size, of

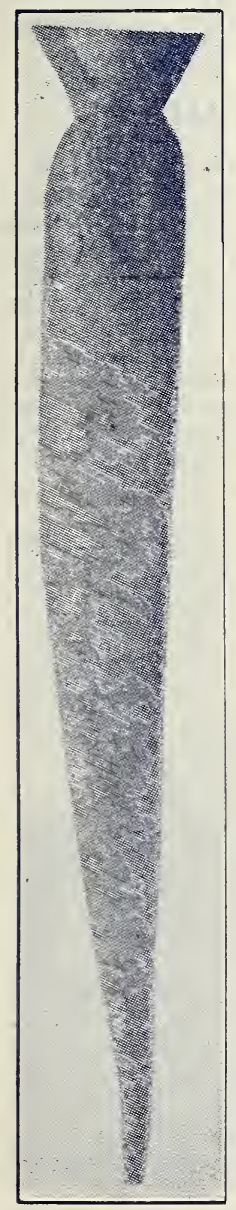

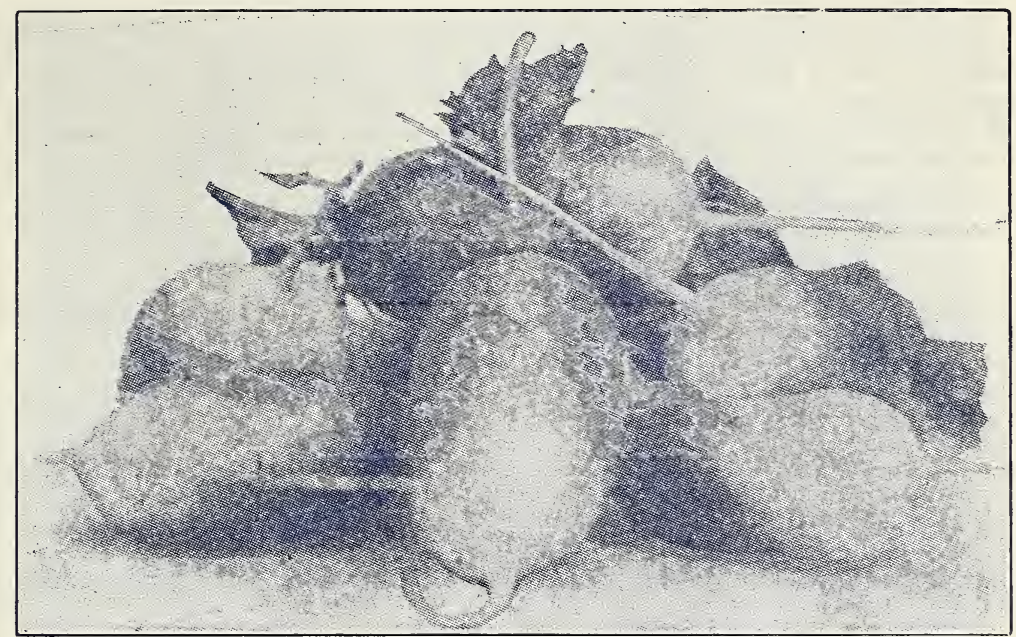

FRENCH BREAKFAST

very best flavor, and will remain in eating condition long without getting pithy. Pkt., 5c; oz., 10c; $1 / 4$ lb., 25c; lb., $75 \mathrm{c}$.

Scarlet Globe-A beautiful, perfectly round, quick-growing radish of excellent flavor, used on a large scale by market gardeners. Pkt., 5c; oz., 10c; 1/4 lb., $25 \mathrm{c} ; 1 \mathrm{~b} ., 75 \mathrm{c}$.

French Breakfast (See Cut)-A fine forcing radish, maturing in twenty days from germination, makes very little top, and may be cultivated very close together. It is oval shaped, skin bright scarlet, but tipped at the end with pure white. Pkt., 5c; oz., 10c; $1 / 4$ lb., 25c; lb., 75 c.

Half-Long French Scarlet-This radish is of beautiful half-long shape, grows large, may be grown under glass or planted outdoors for spring or fall crop. Pkt., 5c; oz., 10c; $1 / 4$ lb., 25c; lb., 75c.

Improved Chartier-A beautiful half-long radish, growing to good size, very firm and brittle, mild and will remain in edible condition for a long time. The root is of bright red, tipped at the end with white. Pkt., 5c; oz., 10c; $1 / 4$ lb., 25c; lb., 75c.

Glass or Cincinnati Market-A long, very smooth radish, of a beautiful transparent red, very brittle and of delicious flavor. Pkt., 5c; oz., 10c; $1 / 4 \mathrm{lb}$, $25 \mathrm{c}$; $1 \mathrm{~b} ., 75 \mathrm{c}$.

Long White Vienna or Lady Finger-One of the best eating radishes known, of distinct variety and appearance. Never gets pithy. Pkt., 5c; oz., $10 \mathrm{c} ; 1 / 4 \mathrm{lb}$., $25 \mathrm{c}$; lb., $75 \mathrm{c}$.

Miss France-It is an early sort, producing very large, long roots of very bright scarlet color, fading at the bottom into pure white, making it very striking in appearance, which renders it very saleable. Pkt., 5c; oz., 10c; $1 / 4$ lb., 25c; 1b., 75c.

Chinese Rose Winter-It is of a beautiful bright rose color, and the finest eating radish of the winter varieties. The seed should be sown in the fall at the same time you sow your turnip crop. Pkt., 5c; oz., 10c; 1/4 lb., 25c; lb., 75c.

Round Black Spanish Winter-A fine, tender and delicious winter radish, never getting tough or stringy. Pkt., $5 \mathrm{c}$; oz., $10 \mathrm{c} ; 1 / 4 \mathrm{lb} ., 25 \mathrm{c} ; 1 \mathrm{~b} ., 75 \mathrm{c}$.

Long Black Spanish Winter-Possessing the same good qualities as the Round Black Spanish. Will stand outdoors all winter. Pkt., 5c; oz., 10c; $1 / 4$ lb., 25c; lb., 75c.

California White Mammoth Winter-This is the largest radish in existence. The roots grow from ten to twelve inches long and two to three inches in diameter. The flesh is very white and solid and of good flavor. Pkt., CINCINNATI MARKET 5c; oz., 10c; $1 / 4 \mathrm{lb} ., 2 \check{\mathrm{c}} ; \mathrm{lb} ., 75 \mathrm{c}$. 


\section{Rhubarb}

How to Grow-Rhubarb succeeds best in loamy soil, the richer its condition and the deeper it is stirred the better. Sow in drills an inch deep and thin out to about six inches apart. In the fall trench a piece of ground and manure it well; then transplant the young plants into it two to three feet apart each way. Cover with leaves or litter the first year, and give a dressing of coarse manure every fall. The stalks should not be plucked till the second or third year, and then pulled, not cut from the plant. The best way to get rhubarb quick is to buy the roots. The large ones come into bearing at once.

Mammoth Rhubarb-Pkt., 5c; oz., 15c; 1/4 lb., 40c; lb., $\$ 1.25$. We can also supply roots Price of roots, 75c per doz. By mail, postpaid, doz. 90c.

\section{Salsify, or Vegetable Oyster}

How to Grow-Make drills about three inches deep and from sixteen to twenty-four inches

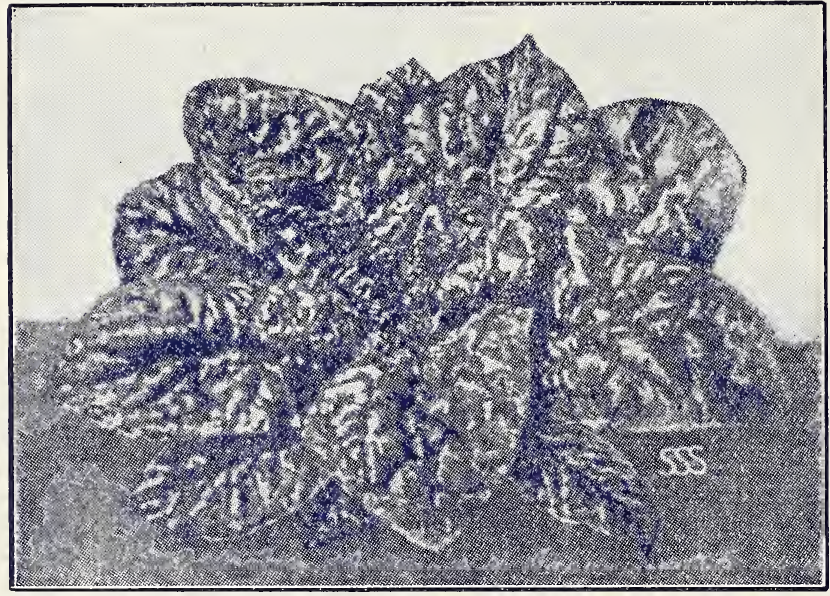

LONG STANDING SPINACH apart and sow the seed, covering about one inch deep. When two inches high thin out to three inches apart and fill up the drills. They are perfectly hardy, and may remain out all winter.

Mammoth Salsify - Pkt., 5c; oz., 15c; $1 / 4$ lb., 40c; lb., $\$ 1.25$.

\section{Spinach}

Spinach may be planted any month in the South except in very hot weather and December and January. Plant same as turnips, either drill or broadcast. The soil must be very rich to succeed.

Broad Leaf Flanders-A vigorous growing variety, leaves very broad and thick, tender and of fine eating quality. Pkt., 5c; 2 oz., 10c; $1 / 4$ lb., 15c; lb., 40 c.

Bloomsdale Spinach -A Savoy leaf variety very tender, good flavor, and will stand longer without going to seed than most any variety. $\mathrm{Pkt} ., 5 \mathrm{c} ; 2 \mathrm{oz} ., 10 \mathrm{c}$; $1 / 4$ lb., 15c; lb., 40c.

Long Standing-Very large leaves, thick, crumpled, of extra good quality, and stands longer than any other sort without going to seed. Pkt., 5c; 2 oz., 10c: 1/4 lb., 15c; lb., 40 c.

Spinach Beet (Swiss Chard)-This plant really belongs to the beet family, is grown for its foliage which makes the finest of greens, available throughout the summer and fall when other greens are scarce. Pkt., 5c; oz., 10c; $1 / 4$ lb., 35c; lb., $\$ 1.25$.

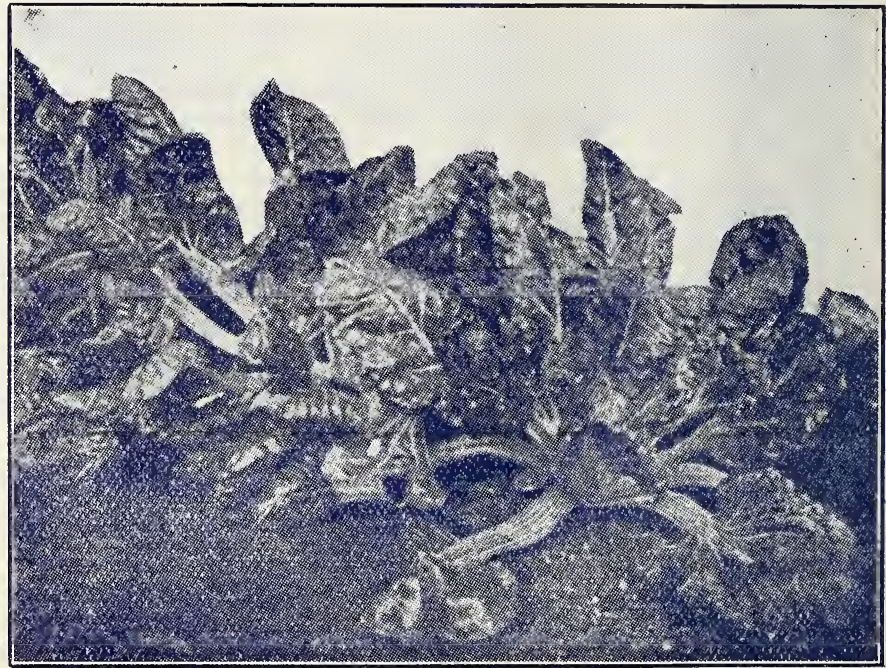

SPINACH BEET-SWISS CHARD 


\section{Squash}

How to Grow-The squash succeeds best in rich, loose subsoil land, and should never be planted on a poor, hard soil. The early varieties may be planted as early as the latter part of March to April. The bush sorts may be grown three or four feet apart, and running sorts given six to eight feet distance. The fall and winter varieties are seldom planted until June or July.

The Best FertilizerAcid phosphate and kainit mixed with stable manure will give the best results; but very little, however, should be used under the plants, it being better to broadcast.

Mammoth White Bush (See Cut)-This variety is identical with the Patty Pan, only differing in its extremely large size. It is a choice selection of the Early White Bush, fully as early and growing to measure twelve to fifteen inches across. Pkt., 5c; oz., 10c; $1 / 4$ lb., 25c; lb., 85c.

Early White Bush, or Patty Pan-This is the old standard variety of early Squash, and has never been excelled as yet. It is the earliest variety yet known, and of the sweetest and most delicious flavor. Pkt., 5c; oz. 10c; $1 / 4$ lb., 25c; lb., 75c.

Giant Yellow Summer Crook-Neck (See $C u t$ )-This new variety of the Yellow Summer Crook Neck, while not thoroughly perfected as yet, is destined to drive the small variety out of the market. It will grow twice as large as the ordinary, and of equally as

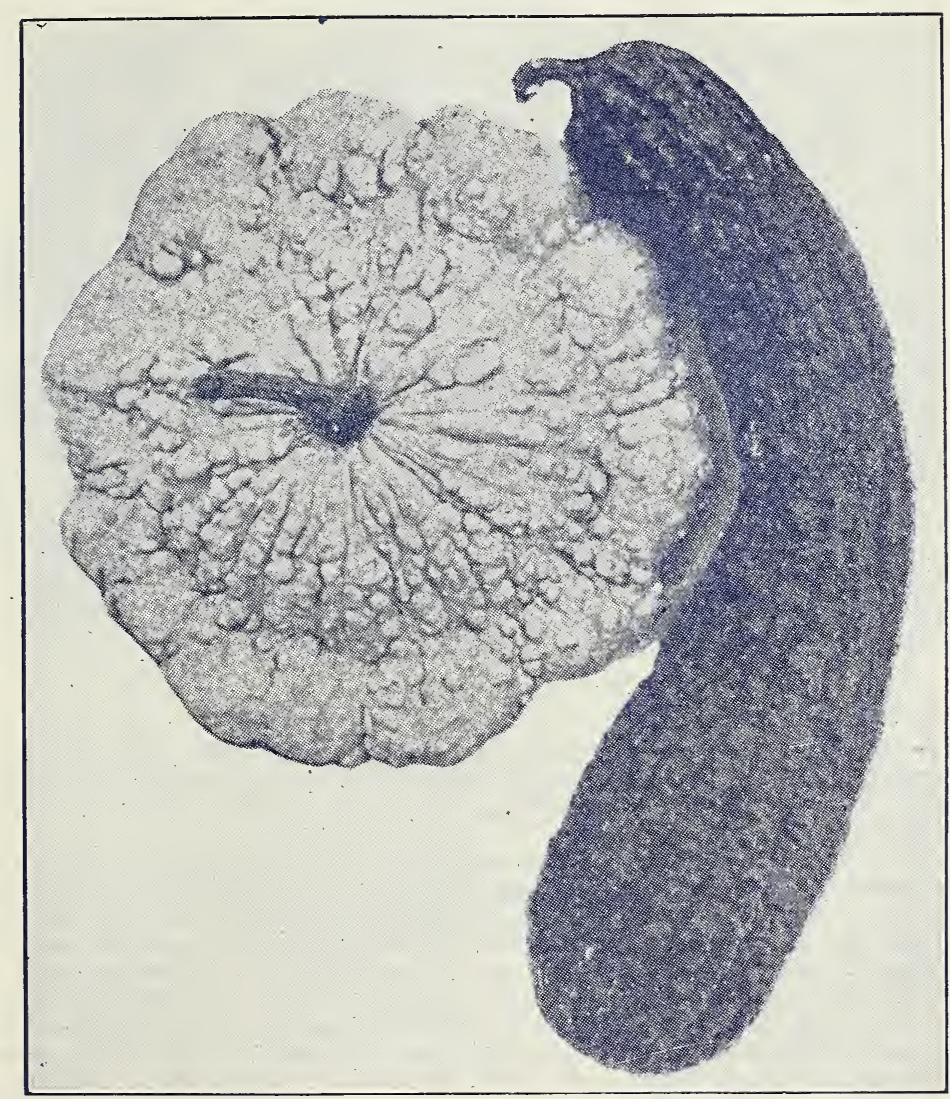

MAMMOTH WHITE BUSH AND MAMMOTH SUMMER CROOKNECK good qualities. This sort stands the hot sun well. Pkt., 5c; oz., 10c; $1 / 4$ lb., 25c; lb., 85c.

Yellow Summer Crook-Neck-This is one of the juciest and most highly flavored of all the squashes. It is a bright yellow color and beautifully warted, and one of the best market varieties. Pkt., 5c; oz., 10c; $1 / 4$ lb., 25c; lb., 75c.

Boston Marrow-The flesh is a very beautiful orange, very fine grained, thick, and of the best quality. Pkt., $5 \mathrm{c}$; oz., $10 \mathrm{c}$; $1 / 4 \mathrm{lb}$., $35 \mathrm{c}$; lb., $\$ 1.00$.

Mammoth Chilli-This is the largest and most beautiful variety on the list. The skin is smooth and of a rich, bright orange color. Used mainly for feeding stock. Pkt., $5 \mathrm{c} ; \mathrm{oz}$., $15 \mathrm{c} ; 1 / 4 \mathrm{lb}$., $50 \mathrm{c}$; lb., $\$ 1.50$.

I Hubbard Squash-This is a good standard variety, a general favorite for table use. It is of very large size, flesh fine grained, dry and of excellent flavor. Skin dark green. It is one of the best winter varieties. Pkt., $5 \mathrm{c}$; oz., 10c; $1 / 4 \mathrm{lb} ., 35 \mathrm{c} ; \mathrm{lb} ., \$ 1.00$.

Golden Hubbard-For the private gardeners this is the best of the Hubbards. The fruits are of the same shape as the green and warted type, but average one-half to one-third less in size, and although earlier in season, keep in excellent shape through the winter. The skin is bright deep orangeyellow, very showy and attractive. Flesh deep golden yellow, much richer in color than Hubbard, fine grained, cooks very dry and is of rich flavor. Pkt., 10c; oz., $15 \mathrm{c} ; 1 / 4 \mathrm{lb}$., $40 \mathrm{c}$; lb., $\$ 1.25$. 


\section{Tomatoes}

How to Grow-Tomatoes undoubtedly succeed best on a rather heavy soil; that is, a soil containing a considerable amount of clay; but it must be rich and well prepared before it is planted in tomatoes. The proper time of the year to sow tomato seed will vary altogether on the time at which

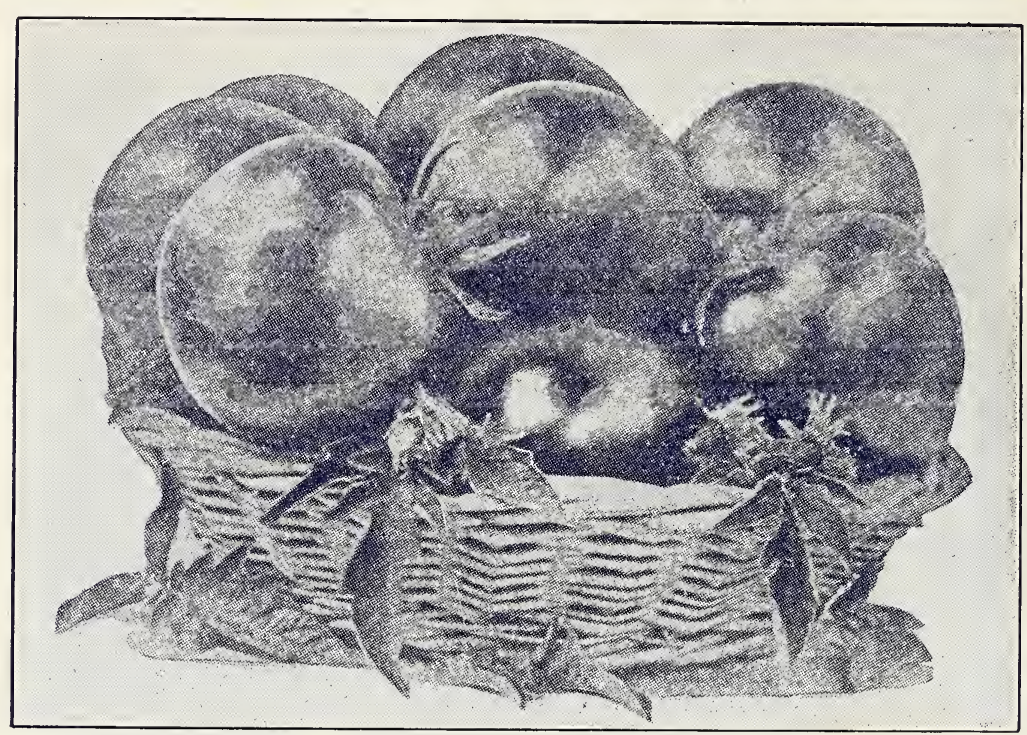

EARLY DETROIT it is desirable to bring the plants into bearing. The professional tomato grower or market gardener always relies more on his early spring crop, and with this end in view usually sows his seed in cold frames or hot beds in December or January, winters them over and gets them out in early spring just as soon as all danger of freezes have passed. The object of sow. ing the seed in the fall or winter is to get an age on the plant before it is set out, but care should be taken not to allow the plant to become tail, but it should be given enough cold to se-

cure a healthy, stocky growth, and at the same time well establishisbottom roots.

Early Detroit-A new variety, shaped like Beauty, somewhat earlier, large and decidedly more prolific. For smooth, fine quality don't think any other sort better. Pkt., 5c; oz., 25c; $1 / 4 \mathrm{lb} ., 85 \mathrm{c}$.; lb., $\$ 3.00$.

Earliana-The plants when young have a yellowish tinge, but change color as it grows older into a dark green. They begin to bloom and put on fruit when ten inches to a foot high, and as the plant grows older begins to spread vigorously, throwing out large base limbs which run around on the ground forming a dense mat of growth. All its branches will be loaded with tomatoes born in clusters. We have seen as"many as seventeen tomatoes in one cluster and all of marketable size. The fruit is large and of a brick red color, skin thick and tough, splendid flavor, few seeds and one of the best shippers. We have seen vines that were not pruned produce as much as one hundred and fifty nice tomatoes. Where they are pruned and tied up to a stake they, of course, will not yield so many, but will ripen earlier producing larger and better fruit. Pkt., $5 \mathrm{c}$; oz., $25 \mathrm{c} ; 1 / 4 \mathrm{lb} ., 75 \mathrm{c} ; 1 \mathrm{~b} ., \$ 2.50$.

Enormous Tomato-This variety is as large as Ponderosa, bright red in color, and of a much better shape. The flesh is exceedingly thick, solid red, no green or tough spots, and hardly any seed. The vine is a most vigorous, rank grower, very large stock. Pkt., 5c; oz., 25c; $1 / 41 \mathrm{lb}$., $75 \mathrm{c}$; $1 \mathrm{lb}$., $\$ 2.50$.

Red Trophy-An old standard red sort, medium late, very prolific and unusually hardy. Pkt., 5c; oz., 20c; $1 / 4$ lb., 50c; lb., $\$ 1.75$.

Golden Queen-A bright orange yellow sort; prolific, medium late, and of fine quality. Pkt., $5 \mathrm{c}$; oz., 20c; $1 / 4$ lb., 75c; lb., $\$ 2.50$.

Mikado, or Turner's Hybrid-One of the hardiest and rankest growers on the entire list. Its foliage is entirely different from other sorts, having more the appearance of an Irish potato vine than a tomato. The fruit is very large, of beautiful purplish pink color, very heavy and solid, and of most delicious flavor. Pkt., $5 \mathrm{c}$; oz., $25 \mathrm{c} ; 1 / 4 \mathrm{lb} ., 75 \mathrm{c}$; lb., $\$ 2.00$.

Matchless-A hardy, vigorous grower; fruit very large, solid and dark red color. In quality it is one of the best. Pkt., 5c; oz., 20c; $1 / 41 \mathrm{lb} ., 65 \mathrm{c} ; 1 \mathrm{~b} ., \$ 2.00$.

Yellow Plum-A curious variety; vines not unlike other sorts, but the fruit is borne in great clusters, resembling when ripe a fine juicy, yellow plum. The fruit is small and unfit for market use, but it is of the very best quality for home use. Pkt., $5 c$; oz., $25 \mathrm{c} ; 1 / 4 \mathrm{lb}$., $75 \mathrm{c} ; 1 \mathrm{~b}$., $\$ 2.50$.

Peach Tomato-A peculiar variety of tomato, resembling a peach very much in form; very solid and of rich flavor. Pkt., $5 \mathrm{c}$; oz., $25 \mathrm{c} ; 1 / 4 \mathrm{lb}$., $75 \mathrm{c}$; $1 \mathrm{H}$., $\$ 2.50$.

Yellow Pear Shaped-A small Italian variety, producing its fruit in great clusters; shaped like a pear. Very rich in flavor and desirable for pickling and preserves. Pkt., 5c; oz., 25c; $1 / 4$ lb., $75 \mathrm{c} ; 1 \mathrm{~b} ., \$ 2.50$.

Red Pear-Same as Yellow Pear, only fruit red. Pkt., 5c; oz., 25c; 1/4 1b., 75c; lb., $\$ 2.50$. 


\section{Tomatoes-Continued}

Livingston's Beauty (See Cut) - The best all-round tomato on earth; exceedingly early, large, smooth, and remarkably prolific. This tomato is absolutely perfect in every way, and is grown more largely by truckers and market gardeners than any other sorts. The variety is of glossy crimson color, with slight tinge of purple; skin tough; good keeper and shipper, and entirely free from green core. Pkt., $5 \mathrm{c}$; oz., $20 \mathrm{c} ; 1 / 4$ lb., 60c; lb., $\$ 2.00$.

Acme-This particular variety is well known to be one of the earliest as well as the most prolific sort grown. The fruit is of good size, almost round, and of a beautiful purplish-pink color. This sort is always smooth, ripening all over at the same time, juicy and excellent. flavor. It is a very hardy sort, and well adapted to the South. A popular one with truckers and market gardeners. Pkt., 5c;.oz., 20c; $1 / 4$ lb., 60c; lb., $\$ 2.00$.

Stone-One of the most valuable all-round sorts of our entire list. The fruit is large, of dark brick red color, solid, fleshy and is not subject to rot like some varieties; nor does it ever have a green core. We can especially recommend it for a late crop. Pkt., 5 c; oz., 20c; $1 / 4$ lb., 60c; lb., $\$ 2.00$.

Ponderosa-Unquestionably the largest tomato grown. The vines are vigorous, producing a very large stalk and an unusually thick stem, which is

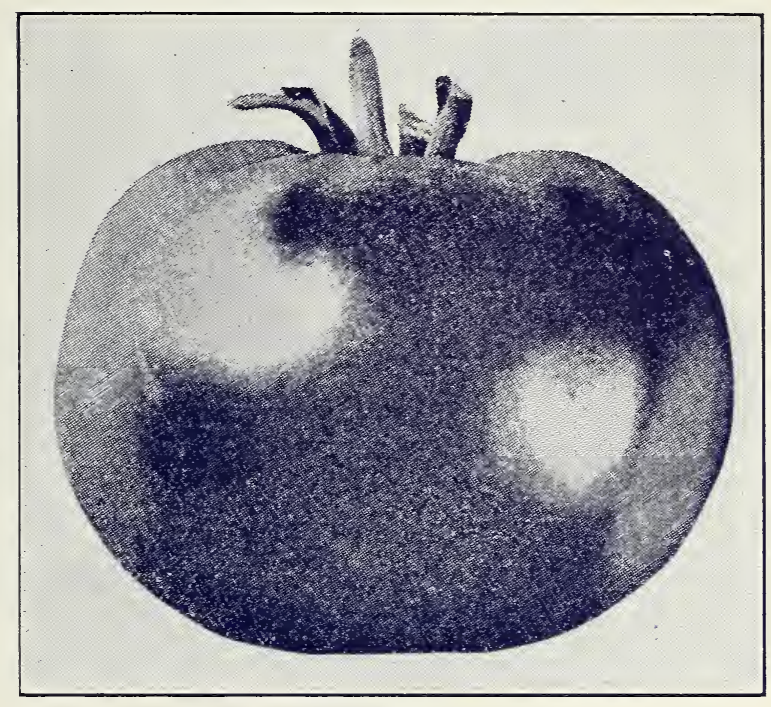

BEAUTY

accounted for in the great size and weight of the fruit. The fruit when ripe is cardinal red, and on account of its compact structure will keep longer than any other sort. Pkt., 5c; oz., 35c; $1 / 4$ lb., $\$ 1.00 ; 1 b ., \$ 3.50$.

Dwarf Champion-A valuable early sort, standing upright. Very prolific, fruit of good size, and resembling the Acme, only firmer, not so many seeds. The foliage is peculiar, being corrugated and of a very dark green color. Pkt., 5c; oz., 25c; $1 / 41 b ., 75 c ; 1 b ., \$ 2.50$.

Livingston's Dwarf Stone Tomato-The Dwarf Stone makes a very large, stocky plant, holding its fruit in great clusters well above the ground; is very smooth, solid and of a brick red color; ripens uniformly and is of the best quality. Pkt., 5c; oz., 30c; 1/4 1b., 75c; lb., \$2.50.

Trucker's Favorite-For the trucker as a main crop purple sort, it has few equals. Is of a beautiful purplish-red color, well riped throughout. The vines are of strong growth, not subject to rust and blight. Very solid, thick meated, most regular in form. Pkt., 5c; oz., 20ّc; $1 / 41 \mathrm{~b} ., 75 \mathrm{c} ; 1 \mathrm{~b}$., $\$ 2.50$.

The Underwood-The vines are of a dark green, grow rapidly and to a great size, bears a heavier crop than any other purple variety and continues bearing until killed by

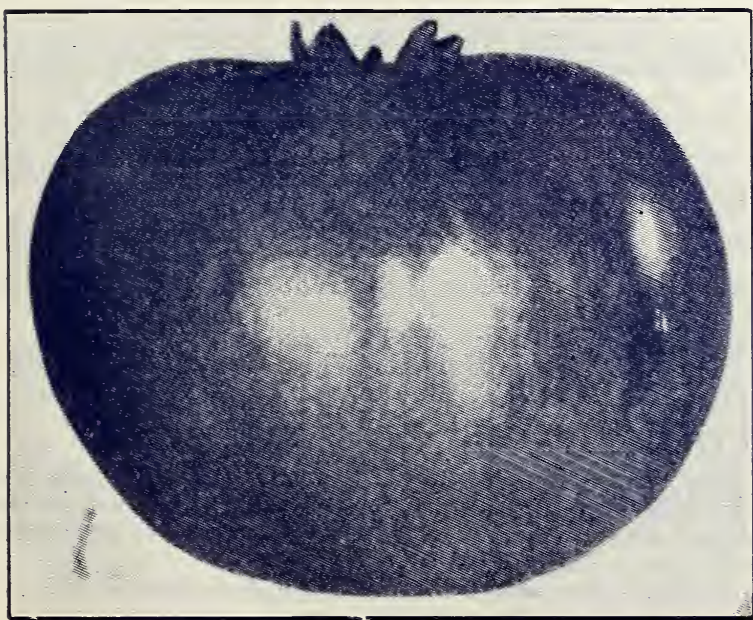

THE UNDERWOOD frost. The fruit is of a beautiful glossy dark or purple red, very large and set in great clusters, and retain their size until the last of the season, very thick meated and of the finest flavor and quality. The seed cavity in the fruit is so small that they are nearly solid, unlike other purple tomatoes, the skin is tough and they will bear long shipments, and hold their firmness several days longer than any other variety. This is a great advantage for the local market as well as for shipping. Is free from cracking, and ripens up evenly around the stems. The fruit of this variety are the most beautiful, most uniform, and have a greater diameter than any other tomato. Many varieties are too long and too thin for their circumference. This objection has been entirely removed in the Underwood. Pkt., 5c; oz., 35c; $1 / 4 \mathrm{lb}$., $\$ 1.00$; lb., $\$ 3.50$ 


\section{THE PLAIN TRUTH ABOUT SEED}

\section{Turnips}

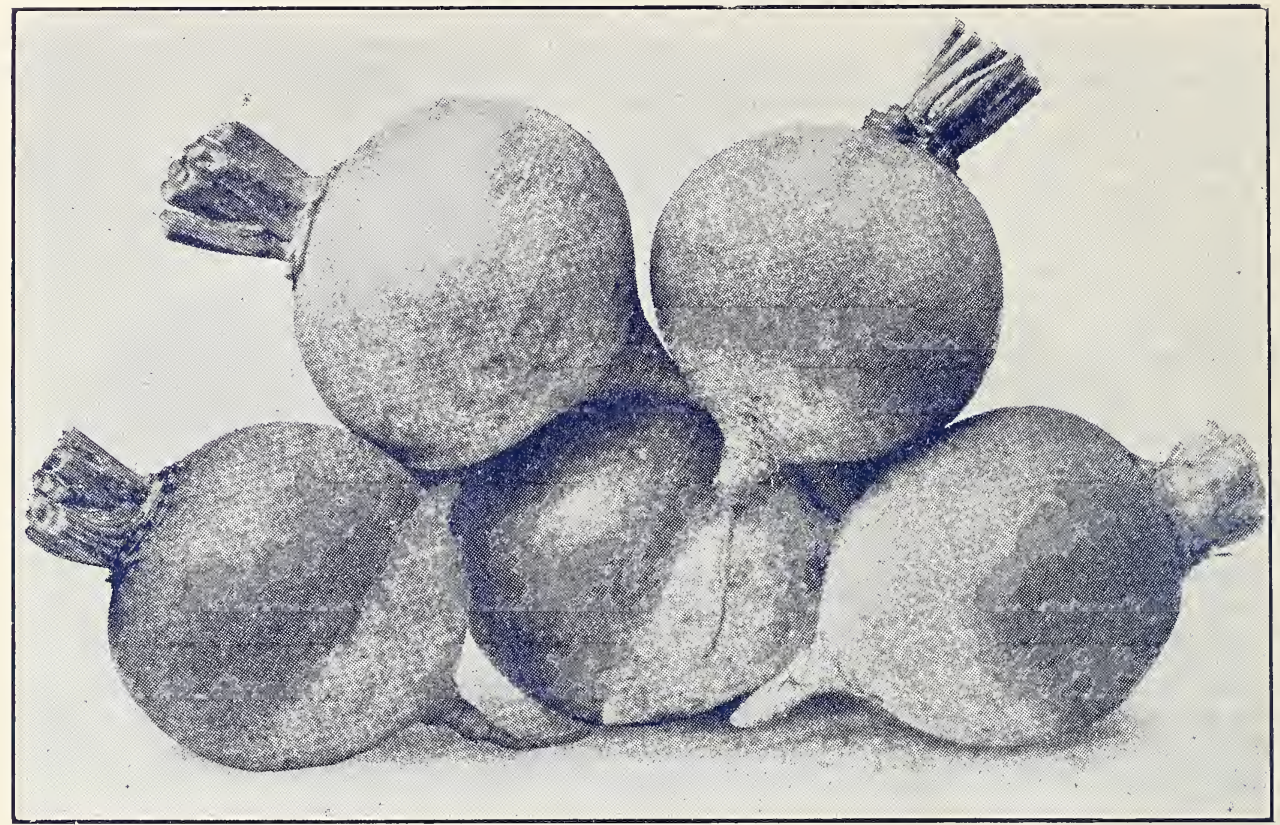

EARLY PURPLE TOP WHITE GLOBE

Early Purple Top White Globe-This is one of the largest and finest of all the turnips; is of a beautiful globe shape with flesh pure white and a red or purple top. It is of very rapid growth for a globe variety, and will produce more to the acre than any known variety. It may be sown either broadcast or in drills. Pkt., 5c; $1 / 4$ lb., 20c; lb., 60c.

Early White Flat Dutch (Strap Leaved) - This is one of the very earliest and choicest varieties grown. It is one of the best sorts for spring sowing. Pkt., $5 c ; 1 / 41 b ., 20 c ; 1 b ., 60 c$.

Red or Purple Top (Strap Leaved) - This is a very early variety, flat, medium size, very small top, with but few leaves, which are of upright growth; flesh fine grained and tender. A purely American variety; will do well to sow either broadcast or in drills. Pkt., 5c; $1 / 4$ lb., 20c lb., 60c.

Large White Globe-It is of a fine globe shape, very large, sometimes growing twelve and fifteen pounds each, and is a large yielder. Pkt., 5c; $1 / 4 \mathrm{lb} ., 20 \mathrm{c} ; 1 \mathrm{~b} ., 60 \mathrm{c}$.

Sweet German-This is claimed by many to be far superior to all as a winter turnip. It should be planted very early, the same time as the Ruta Baga. The flesh is extremely hard and a beautiful white, and keeps as sound as a rock. Pkt., 5c; 1/4 lb., 20c; lb., 60c.

Amber Globe - The flesh is beautiful yellow, very fine grained and very sweet. It will grow to very large size in the South; is one of the very best keepers for winter use. Pkt., 5c; $1 / 41 \mathrm{~b}$., 20c; lb., 60c.

Large Yellow Globe-This is somewhat the same variety as the Amber Globe, differing a little in shape. Pkt., 5c; $1 / 4$ lb., 20c; 1b., 60c.

Long White Cow Horn-This is a very fine winter variety, penetrating deep into the gronud, and standing the entire winter. Its growth in shape is similar to a cow's horn. Pkt., $5 \mathrm{c} ; 1 / 4 \mathrm{lb} ., 25 \mathrm{c} ; \mathrm{lb}$., $75 \mathrm{c}$

Purple Top Yellow Aberdeen-This famous foreign variety, resembling in shape a finely formed

Ruta Baga, is splendid for stock feeding as well as table use. Pkt., 5c; $1 / 4$ lb., 20c; lb., 60c.

Early White Egg-Beautiful oblong, early white sort, fine keeper and market variety. Pkt., $5 c ; 1 / 4$ lb., 20c; lb., 60c.

Milan, Purple Top-The earliest turnip known; small flat purple top; small top grows on top of ground. Pkt., 5c; oz., 10c; $1 / 4$ lb., 35c; lb., $\$ 1.00$.

Seven Top-Old fashioned winter greens. Pkt., 5c; 1/4 lb., 20c; lb., 60c.

Dixie Land or Southern Prize - The finest winter turnip grown; identical with the Seven Top except it makes a very fine, large white turnip. Pkt., 5c; 1/4 lb., 20c; lb., 60c.

\section{Ruta Baga}

Sow in drills latter part of June and July, make soil rich and cultivate well. When plants begin to form bulbs, throw plenty of dirt to them, which causes them to form a bulb and prevents them from going to shank. Ruta Bagas should be thinned out shortly after coming up, to from six to eight inches apart. If not done promptly they will not amount to anything.

Improved Purple Top Yellow Ruta Baga-One of the finest and best shaped sort. Pkt., 5c; $1 / 4$ lb., 20c; lb., 60c.

White Ruta Baga-Pure white, fine shape. Pkt., 5c; 1/4 lb., 20c; lb., 60c. 


\section{Fertilizers, Fertilizer Chemicals, Etc.}

We are extensive dealers in fertilizers of all kinds, including complete fertilizers and fertilizer chemicals. We can handle carload buyers to advantage within a radius of one hundred and fifty miles from Birmingham.

We can furnish you, every month in the year, fertilizers or chemicals in any quantity wanted, from five cents' worth up. Most dealers do not break two hundred pound sacks, but we supply any number of pounds wanted.

About Prices-We don't sell fertilizers on credit, and it does not pay any one to buy on credit, because the difference in cash and credit price is too wide. In short, one should pay cash for fertilizers, even if he has to borrow the money at 8 to 12 per cent. Prices on fertilizers and fertilizer material fluctuates, and we do not guarantee our list price, but request those interested to write us for special prices, always stating quantity wanted.

Special Truck, 10-4-4-This is a high grade complete fertilizer, containing ten per cent of phosporic acid, four per cent of ammonia and four per cent of actual potash. This means that in a ton there would be $200 \mathrm{lbs}$. actual phosphoric acid, $80 \mathrm{lbs}$. of pure ammouia and $80 \mathrm{lbs}$. of pure potash. It should be understood, of course, that the plant foods, phosphoric acid, ammonia and potash, can not be used in a chemical pure form, but must be diluted or contained in a mixture with other agents. This formula is suitable for practically all crops; in fact, it might be called a universal fertilizer suitable for all classes of crops. It will be found cheaper, formula considered, than lower grade goods. Price: lb., 3c 100 lbs. for $\$ 2.50$.

Fertilizer Chemicals - IVe always carry a full line of chemicals for making special fertilizer mixtures so that those wanting a special formula for a certain class of crops and on certain soils can have such chemicals as is needed. We are in position to furnish formulas and supply the ingredients when we are supplied with full information. Write us your wants.

Nitrate of Soda-This is ordinarily the cheapest concentrated form of ammonia or nitrogen that can be bought commercially. It is very profitable to use on most any class of crops where quick, vigorous growth is demanded. It is usually applied after a crop is growing, because it is available so quick that it can't be used to profit when seed are planted, except on very quick maturing stuff. It is valuable in composts, and especially desirable to hurry on cabbage, onions, lettuce and other vegetables, also to draw up wheat and oats. Price, per lb., $4 \mathrm{c} ; 100 \mathrm{lbs}$., $\$ 3.50$. Write for price in quantity.

Kainit-It runs twelve to fifteen per cent. of actual potash, and its values are based on its content of potash. The other eighty-five per cent is gypsum, salt, carnalite, etc., and while these salts are not plant foods, they do exert more or less influence on crops. Kainit is recommended as an insecticide and germicide; prevents rust in cotton, scab on potatoes, and destroys numerous insetcs in the soil where applied. It is splendid to put in the compost or any formula requiring potash, or it can be used independently from other fertilizers or, in addition, at the rate of two to four hundred pounds to the acre. Price of Kainit.

Muriate of Potash-This is an important potash salt, running from fifty to fifty-five per cent actual potash. It is one of the most soluble forms of potash that can be obtained commercially and is more largely used than any other form. It is more largely used for the reason of its concentration. The saving in freight alone is a considerable item. Muriate of Potash is used in compost, and is nearly always the source of potash in all complete fertilizers. It is largely used independently of other fertilizers, or is added to so-called complete fertilizers to bring up the per cent of potash to the desired amount. Potatoes, cabbage, turnips and beets especially need muriate of potash.

Sulphate of Potash-A very desirable form of potash, especially adapted for slow-growing or crops that require a long time to mature, such as cotton. It is not as good for vegetables or quickgrowing crops as the muriate, because not so quickly available. It contains fifty to fifty-five per cent of actual potash. Write for price in quantity.

Sulphate Ammonia-This is a highly concentrated ammonia, often running twenty-five per cent ammonia, and is the most economical form of ammonia that can usually be obtained. It is not as quickly available as nitrate of soda, but is more lasting and for slow-growing crops is highly recommended. It is best to use in home mixtures. Price, lb., $4 \frac{1}{2} / 2$; 100 lbs., $\$ 4.00$.

Ground Tobacco Stems-This is another source of potash, besides ammonia. The goods we handle run $101 / 2 \%$ potash and $31 / 2 \%$ ammonia; so, with the addition of acid phosphate, you can produce a complete fertilizer. Tobacco stems are used in certain formulas for their potash, ammonia, and their ability to destroy insects. This is a valuable stuff for applying on melons, squash, cucumbers, etc., to drive away insects.

Acid Phosphate-We handle $16 \%$ goods. It is always cheaper to buy the high grade or $16 \%$ goods, beacuse you buy a pound of actual phosphoric acid in the $16 \%$ cheaper than in the $14 \%$; and when you have to pay freight on the goods you pay as much for cheap goods as you do for the high grade. Price $16 \%$ acid, bag of 100 lbs., $\$ 1.00$.

Bone Meal-The cheapest fertilizer on the market, when you take into account what you really get for your money. Price per lb. 3c; 100 lbs. $\$ 2.50$. 


\section{Alfalfa}

Alfalfa is one of the most valuable perennial leguminous forage and hay plants in cultivation. It is grown with more or less success in nearly every State in the Union. The plant in appearance differs widely from other clovers. The young plants are of a beautiful emerald green color, growing

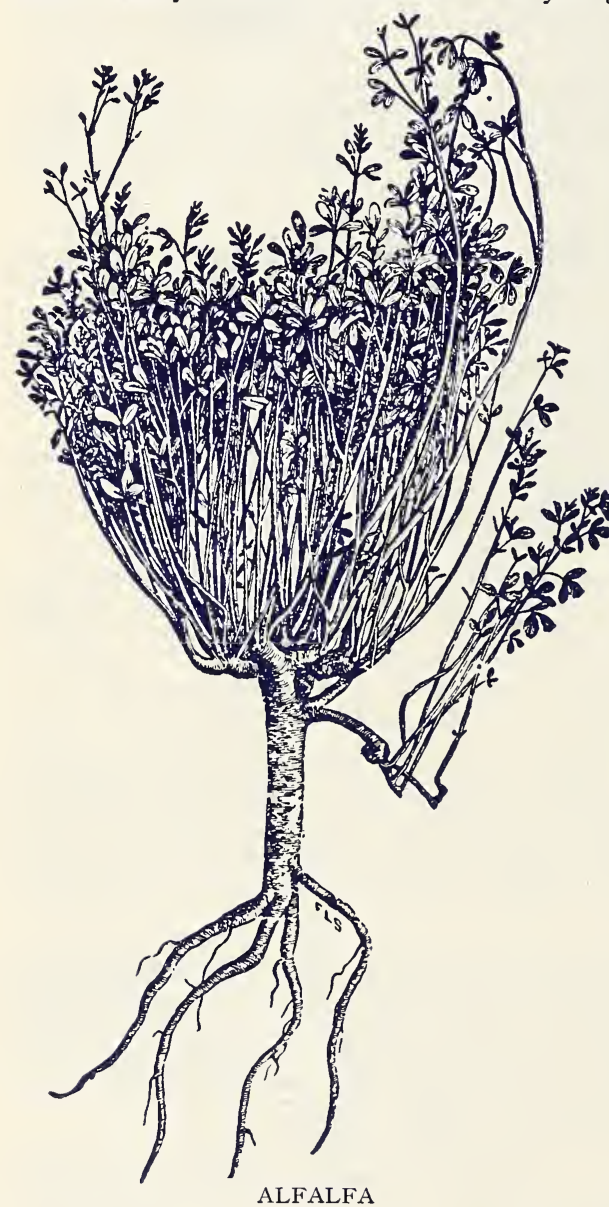
upright and branching in character. The leaves are smooth and three-parted, each part being broadest above the middle and rounded in outline. The plant produces, after it gets 12 to 24 inches high, bluish purple flowers in clusters, distributed on different parts of its structure.

The root system of the plant is the most wonderful thing in connection with its growth. There is no telling how deep the roots of Alfalfa will penetrate. They have been discovered below the earth's surface more than a hundred feet. The depth to which they will penetrate depends largely on the physical condition of the soil below the surface, also the depth of the water table, which the roots always seek. Generally speaking, the soil best suited for Alfalfa is a sandy loam with a porous or gravelly clay subsoil. But as so much depends on the underlying soil, no definite recommendations can be given. A safe conclusion can only be reached through a practical experiment. Usually bottom lands are adapted to Alfalfa, provided they do not overflow or the water table be not too close to the surface. It should be understood that Alfalfa does not stand overflowing, nor will it succeed on sobby or wet lands. Soil containing a good per cent of water soluble lime, when other conditions are correct, is usually a good situation for Alfalfa. Alfalfa will establish itself much quicker where the soil is inoculated with the same bacteria that infests the roots of this plant in favorable Alfalfa sections. Such inoculation may be effected by mixing the seed to be sown with soil removed from an old-established field of Alfalfa. Ten bushels of such soil is said to be sufficient to inoculate an acre of ground. It should be interesting to know that the same bacteria that infests the roots of burr clover and melilotus are identical to that on Alfalfa. So, wherever such plants are found growing may be said to be a favo rable situation for Alfalfa. Soil intended for Alfalfa should be broken very deeply and made as fine as possible. In most cases it will be found profitable to apply as much as two hundred pounds of high grade complete fertilizer to the acre. This will give the plants a good start, feeding them until the bacteria takes hold. The quantity of seed for an acre will depend largely on the quality and the method of planting. Good seed only should be sown, and at the rate of 25 to 30 pounds to the acre. The seed may be broadcasted by hand or with a broadcast seed sower. An ordinary harrow will cover them deep enough, providing it is not very dry when sown. Rolling after sowing is advantageous, provided it be dry. Alfalfa may be sown in September, October or November, or during February, March and April. Fall sowing should prove more profitable, although such is not always the case. It is better not to risk all at the same time. No cultivation is usually given young Alfalfa, but there are times when spring sowing can be harrowed to great advantage shortly after the pants are up, provided the ground is foul with weeds or has become baked. After the plants are establislhed for two or three years cultivation may be given with benefit each spring, after all danger of freezing is past. This cultivation is given with a disc harrow, with disc set perfectly straight. This working will split up the old crowns, stir the soil and seem to assist the plants in spreading, thus establishing a better stand. Alfalfa should be cut for hay when blooms begin to appear, and where delayed too long the quality of the hay will be much impaired. Great care must be exercised in curing and handling to prevent loss of leaves. The feed value of Alfalfa hay is very high. In fact, it is almost a complete ration for a work horse. Alfalfa may be cut from two to five times in a season. The yield to an acre in a season will vary from one to six tons of dry hay.. Price, government tested seed, $1 \mathrm{~b} ., 25 \mathrm{c}$ By mail postpaid, lb. 35c. Write for price' in larger quantities. 


\section{Clovers}

Caution-Don't buy cheap clover seed. It does not pay. You frequently get a crop of undesirable weeds, but no clover. We handle but one grade, and that the best obtainable. We not only test the seed ourselves, but have purity and vitality test made by the Agricultural Department, Washington, D. C. We are prepared to furnish the government test on any grass or clover seed we sell and will send samples to those interested, so they can see just what we propose to ship.

Melilotus (Sweet Clover) -What we offer is the true Melilotus Aba, or White Blooming Sweet Clover. There is a yellow blooming variety, growing wild in the North, which is practically worthless, so be careful, and insist on the Southern grown white blooming variety. It is classed as an annual as well as a biennial, but as a matter of fact, it is mostly perennial in the South; in other words, while it dies down after seeding, but will come up from the old roots in early spring. The roots are large, white, go deep in the soil, resemble alfalfa, and the naked seed looks like alfalfa. This plant is widely distributed over a large area of the United States. It delights in lime lands, and will thrive well even on worn out places. Wherever blue grass, clover and alfalfa thrives Melilotus can be grown. The Melilotus plant is very much like alfalfa in appearance, but grows more rapidly, produces a much larger and taller stalk, but it not near so valuable as a hay plant. Melilotus is perfectly hardy in Alabama, and may be sown most any month in the year. It possesses the same bacteria on its roots as alfalfa, so wherever Melilotus is found growing luxuriantly alfalfa will thrive, and since Melilotus will grow on a greater variety of soils than alfalfa, through its use the area of alfalfa can be greatly increased. The seed, no matter when planted, will lie in the soil and come up at the proper time. It is frequently sown with winter grain in the fall of the year. When the grain is cut off in the spring the clover will come out and be ready to cut for hay very shortly. This is a valuable clover for bee raisers. ? It can be cut repeatedly if rains are plentiful. Price of seed in rough, lb., 20c; bu., 25 lbs., $\$ 3.75$. By mail, postpaid, lb., 30c

\section{Bur Clover}

(Medicago Maculata.)-Bur Clover is an annual winter clover of the legume family, and is much prized in a large section of the South for a winter pasture, either by itself or in a mixture with winter grains. The plant belongs to the same family as alfalfa, and the naked seed is very much like alfalfa, kidney-shaped and light egg-yellow color, but the seed of the Bur Clover are borne in a small, tiny, round coiled up prickly bur. Bur Clover after making its appearance above ground, is of a rich, dark green color. The leaves are longer than red clover and always toothed above, and usually have a dark spot near the center. The plant produces small yellow flowers from April to June, after which the plant makes seed and dies out. The plants will re-seed themselves, but no growth will ever be made from the old roots. The plant's chief value is its ability to fertilize the soil and afford a splendid pasture during the winter.and spring for all classes of live stock. Bur Clover may be planted at any time from August to November; early plantings are to be encouraged. If it is to be the sole crop from twenty-five to thirty pounds in the bur should be used in seeding an acre. But where sown with winter grain one-half this amount will answer. Bur Clover is now being largely used for the purpose of in. oculating the soil for alfalfa. The same bacteria inhabits the roots of both plants alike. Bur Clover will succeed on a greater variety of soils than alfalfa, consequently through the use of Bur Clover the alfalfa area can be largely extended. One of the greatest missions of Bur Clover is to prolong the green period of Bermuda grass. This is accomplished by sowing a Bermuda pasture during the fall in Bur Clover. The seed will germinate and cover the Bermuda with a beautifyl carpet of green by the time freezes would be dangerous. This covering, besides being valuable grazing itself, protects the Bermuda from freezes, thus producing a permanent pasture throughout the winter. Bur Clover will re-seed itself in the spring, disappear and come up again the following winter. Better results may be had, however, by sowing Bur Clover on Bermuda if suitable preparations be made. Such preparations may be effected by running a small plow through the Bermuda sod, so as to provide a place for the Bur Clover.

Seed in bur, lb., 20c; by mail, postpaid, lb., 30c. Write for price in season. 


\section{Clovers}

Crimson Clover (Trifolium Incarnata)-An annual rank growing clover, desirable for winter and early spring pasture, valuable as a green maturing crop to turn under in spring and makes splendid hay when cut just as it comes into bloom. Where cuttings are made after bloom is fully matured the hay will not be so good. Crimson Clover should be sown from August to November the first. Where sown by itself, twenty-five to thirty pounds are required for an acre. Where sown with winter grain or vetches, fifteen pounds would be sufficient. It is often sown in cotton at the last plowing, the shade afforded by the cotton will protect it from the hot sun. Price, lb., $12 \frac{1}{2} \mathrm{c}$. Write for prices in season.

Japan Clover (Lespedeza Striata)-This is a low growing annual leguminous plant, enriches the soil, thrives under conditions that no other clover or grasses will, and is of great value for pasturage during the latter part of the summer, when other things have died out. Unless cut late or heavily pastured it will re-seed itself. On rich bottom land it grows tall enough to cut for hay, and is valuable for this purpose, although its chief mission would seem to be the furnishing of a summer and early fall pasture. Sow 20 to 25 pounds to the acre, either in fall of year with grain or grasses, or in early spring by itself or with grain or grasses. Lb., 20c. By mail, postpaid,1b.,30c. Write for price in quantities.

White Dutch Clover (Trifolium Repens) - Sixty pounds to the bushel. A small spreading perennial clover, indigenous to all parts of the United States. May be sown any time from September to March. It should be sown in the same manner and treated the same as Red Clover.

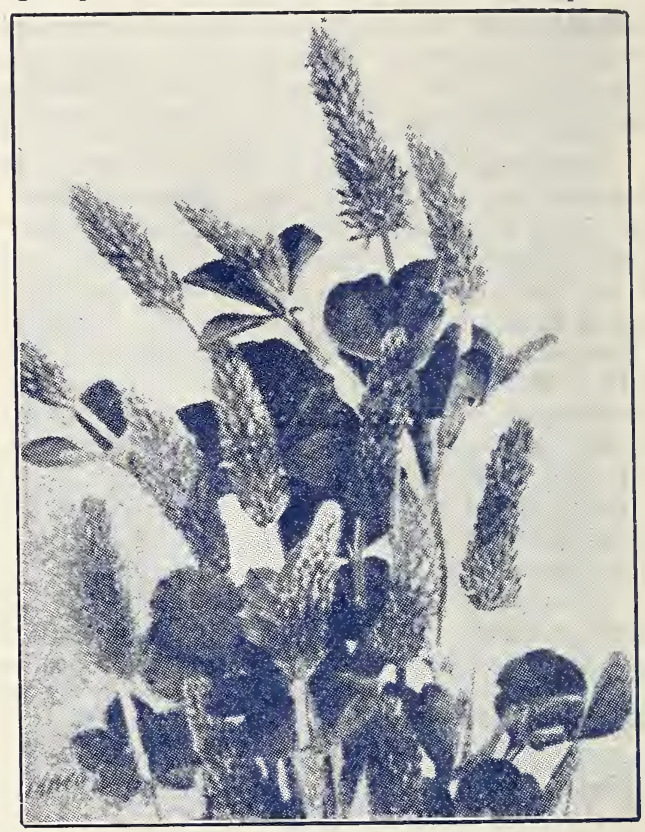

CRIMSON CLOVER

White Clover is largely sown in some sections to provide a bee pasture. About 10 to 15 pounds is sufficient to seed an acre, but if mixed with other grasses half this amount will do. 16. ${ }^{6}$ Price, per lb., 50c. By mail, postpaid, lb., 60c.

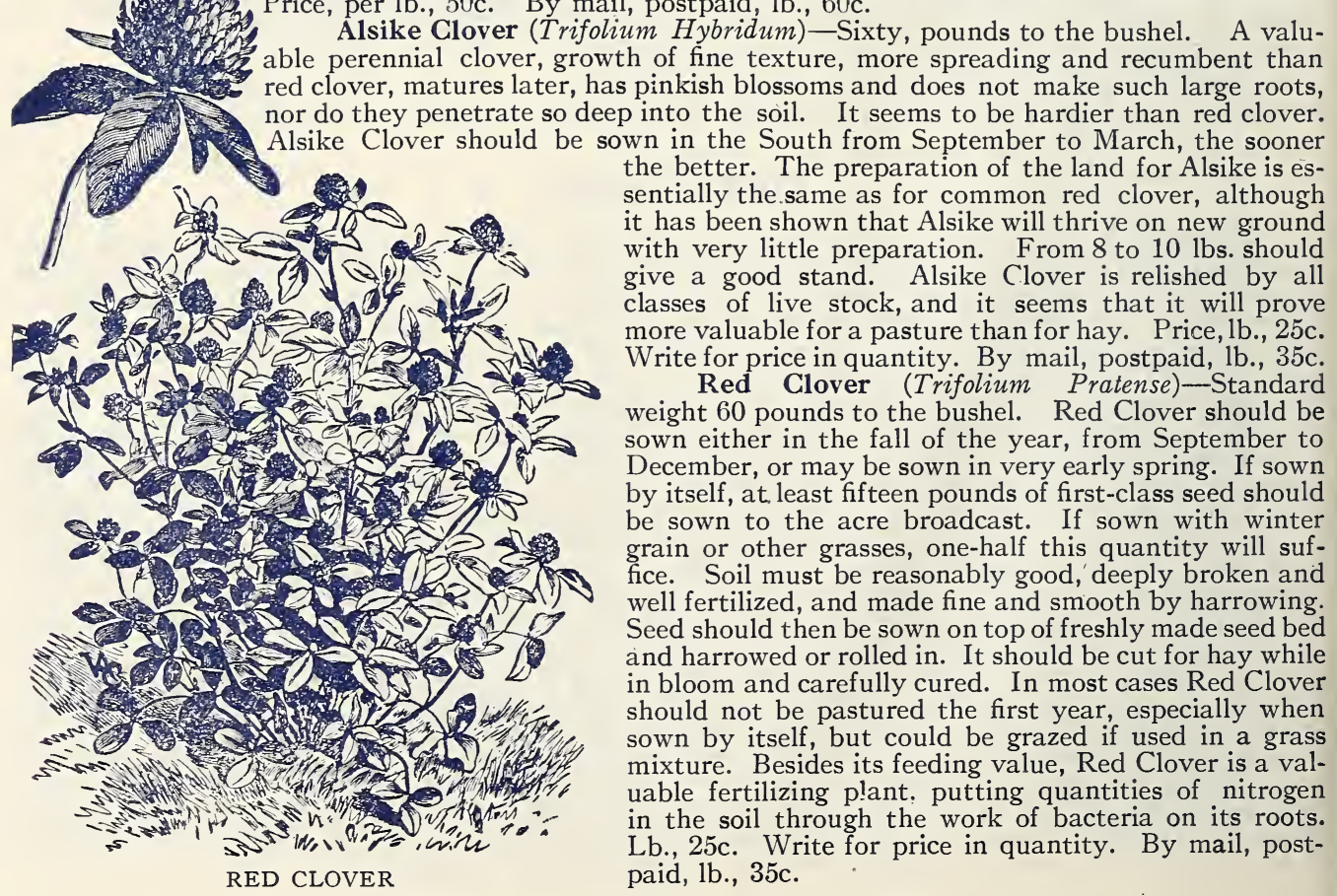




\section{trade FARMOGERM mark}

Ninty per cent. of the actual farm lands throughout the country are yielding not over $25 \%$ of their capacity. This means that $90 \%$ of the farmers of the country are getting about 25 cents from their farms where they should get $\$ 1.00$. Through experiments carried on by the Department of Agriculture it has been demonstrated that this tremendous loss is due to negligence of soil conditions-and the fact that these conditions can be easily remedied makes this announcement all the more startling. The remedy is within the reach of every farmer in the land, and consists principally in planting such legume crops as

\section{Alfalfa, Cow-Peas, Soy Beans, Clovers, Vetch Peanuts, Peas, Beans}

These legumes should be inoculated and planted in land which is not sour or acid. The majority of the farm lands of the country are in a sour condition, but this is very easily corrected by an application of lime. After you have supplied the lime, then plant the legume seeds which you have inoculated and you will grow a tremendous amount of foliage. This can be cut and cured as hay-or, better still, turned under, which will add great quantities of humus. The roots of the inoculated legumes will add vast quantities of nitrates to the soil. To realize that you can more than double your crops of corn or wheat or cotton by simply planting legume seeds which have been inoculated, shows you that in this way

\section{It is Possible to Increase Your Farm Value More than $100 \%$}

If you could get $\$ 2$ a bushel for your corn, or 30 cents a pound for your cotton, or $\$ 3$ a bushel for your wheat, you would consider it was time to sell every bit that you had on hand; yet you can get this same amount of money by increased crops, with practically no additional work, and at the same time increase the permanent value of your farm by commencing this year to make your soil yield greater returns.

We cannot urge too strongly the liming of your land and planting inoculated legume seed. It means a bountiful return for the same labor which you are now giving

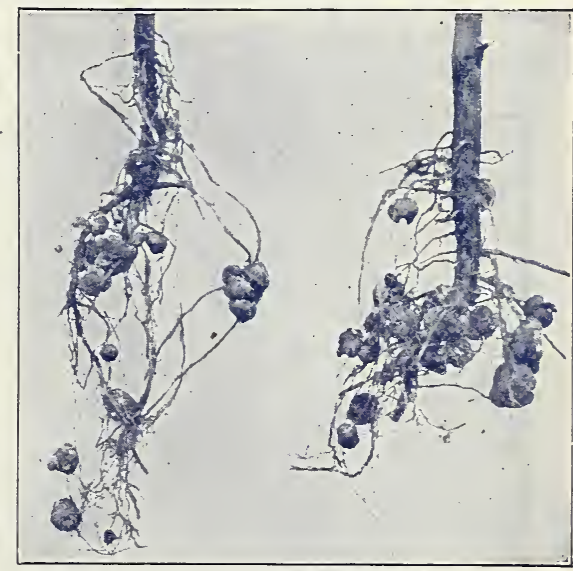

Nitrate sacks on the roots of Soy Beans. These sacks or nodules contain nitrates which enrich the soil for other crops.

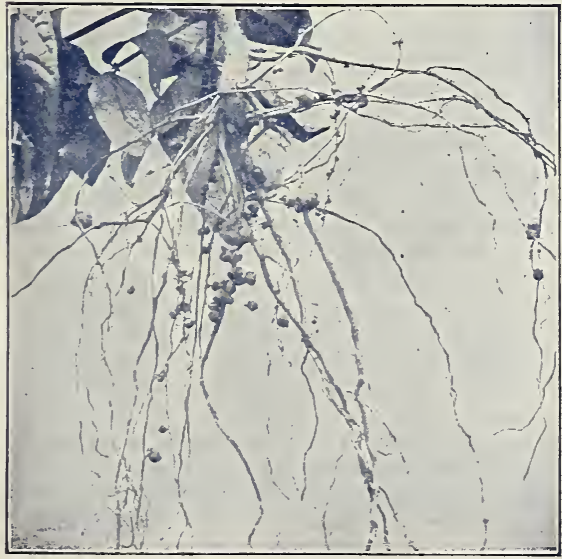

Nitrate sacks on Cow-pea roots. 1200 lbs. of nitrates to the acre equal to $\$ 30$ worth of nitrate of soda or 8 tons of manure, may be deposited in the soil in this manner. to secure a mere living. The future of agriculture in this country depends on good seed, good inoculation and good soil conditions. We sell high-grade seed, as we always have, and we now offer the highly recommended inoculation called Farmogerm. This inoculation comes prepared in bottles ready for use. You can inoculate your seed in a few minutes, and its cost is but $\$ 2$ per acre, or $\$ 9$ for five acres. It is endorsed by the leading farmers and agricultural experiment stations throughout the country.

\section{We Strongly Recommend Our Cus- tomers to Inoculate all their Le- gume Seeds with Farmogerm}

Farmogerm comes in a liquid form, easy to prepare. Full directions on bottle. We can supply it for Alfalfa, Melilotus, Bur Clover, Cow Peas, Soy Beans, all Clovers, Vetches, Peanuts, Garden Peas, Garden Beans and Flowering Sweet Peas. Price, by mail, postpaid: Package for açre, $\$ 2.00$; small, or trial package, 50 c.

Write for special price in large quantities. 


\section{Grasses}

The average Southern farmer knows little about the cultivated grasses, and of their enormous importance from an economical standpoint. Most of them seem to prefer to exchange cotton with the North and Northwest farmer for hay on which to feed their stock for growing a cotton crop. It is surprising that they do it, when sufficient hay can be grown in the South much cheaper than it is produced in the North, to say nothing of the enormous freight charges that must be added to the farm price in shipments to the South.

It must be admitted, that the sowing of grasses in the South is increasing steadily, but the progress is a mazingly slow when one considers the success that every farmer makes who undertake to grow his own hay.

Chief Causes of Failure-One of the chief causes of failures with grasses is cheap seed and another important cause is lack of projo preparation and the use of too-little seed for an acre; and, again, farmers usually put off sowing until the season is out.

General Directions - Where grasses are sown by themselves, the soil must be thoroughly broken and harrowed until perfectly smooth and fine. The seed should then be broadcasted and dragged or harrowed in, covering very lightly. Rolling is of great advantage, especially when it is liable to be dry weather. Of course, grasses may be sown on rough ground, with little or no preparation, but in such cases a much larger amount of seed will be necessary to make a showing. When sown in fall with grain, the seed should be broadcasted on fresh plowed ground after the grain is covered, and then harrow in grass seed.

About Prices-Nothing fluctuates so often and widely in price. We don't guarantee catalogue prices, and urge our customers to write for prices, always stating quantity wanted.

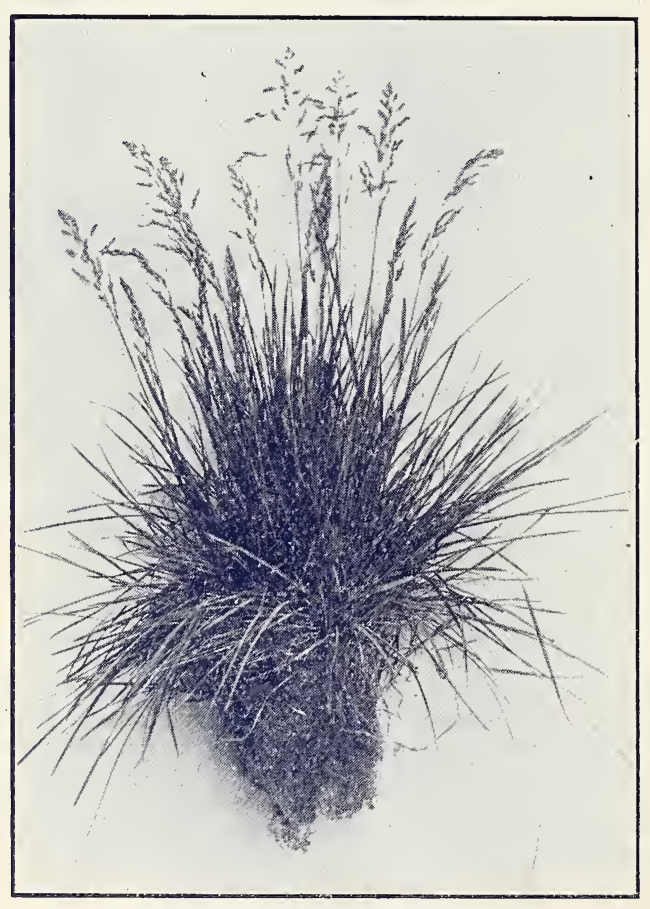

RED TOP OR HERDS GRASS

Red Top or Herds Grass (Argostis Vulgaris) - The soil best adapted for the successful growth of Red Top or Herds Grass is any soil that will grow other grasses or good crops of grain; but it is peculiarly adapted to damp situations, and makes its best growth in low, wet lands and its ability to stand any amount of overflowing has caused it to be extensively used throughout the South.

Its chief value is a pasture grass, although it is largely used in some sections for hay. The prepiration of the soil for Red Top is an important item. Since the seed are so small it becomes necessary, in order to produce an even, uniform stand, to have the soil in a well pulverized condition before seed are sown. When it is to be the sole crop the ground should be broken deep and cross-harrowed to remove all lumps and rough surfaces. The seed should then be sown broadcast on the freshly prepared seed bed, covered very lightly and rolled where practical. The quantity of seed to sow an acre will depend altogether on the quality of seed sown.

When the chaff seed are sown, even of fair quality, it will require at least four bushels to produce an ordinary stand, but if fancy cleaned seed are used from six to ten pounds will be ample for seeding an acre.

The proper time of the year to sow Red Top is anywhere from the first of August to the first of November, or it may be successfully sown in very early spring. The time to sow will depend, of course, on what is desired in the resulting crop. If it is intended as a winter pasture, of course it is necessary to sow in the fall of the year, but if it is intended only for hay crop, it may be advisable to sow in the very early spring. The early spring sowing would also furnish some pasture, even before the time to cut the crop for hay. These seed may be sown by themselves or mixed with other grasses. The proper time to cut it for hay is when it is in bloom and the seed stalk has begun to turn a straw color. Price of extra clean seed, per lb., 35c. Write for price in quantity. If ordered by mail, add $10 \mathrm{c}$ per lb., for postage.

Italian Rye Grass (Lolium Italicum) - This grass resembles English Rye Grass considerably, the most notable difference being that in most cases it is an annual, and, of course, will not last as long. It is very valuable, vigorous growing grass, suitable for furnishing in very short time a splendid green pasture. It forms a good turf, and stands the dry weather remarkably well. This grass can be sown with success either in the fall of the year or very early spring. On rich land it will grow from 2 to 3 feet high. From 40 to 60 pounds of seed should be used in seeding an acre. Price, per lb., 15c; per bu., of 14 lbs., $\$ 1.60$. By mail, postpaid, lb., 25c. 


\section{THE PLAIN TRUTH ABOUT SEED MCVAY SEED AND FLORAL COMPANY}

\section{Grasses-Continued}

Perennial or English Rye Grass (Lolium Perenne)-This grass has been introduced in the South in the past few years, and has proven valuable in grass mixtures for permanent pastures. It is very quick growth, affording in connection with other grasses, not only valuable green forage, but will yield, when cut in bloom, a large quantity of hay. It has given good satisfaction in wood meadow pastures, and we can strongly recommend it for this purpose. On good land it will grow from $1 \frac{1}{2}$ to 2 feet high. The Perennial Rye Grass is also largely used in the South as a lawn grass. From 40 to 60 pounds of seed should be used in seeding an acre; that is, where used by itself. If sown in mixtures much less quantity will suffice. Price, lb., $15 \mathrm{c}$; bu. of 14 lbs., $\$ 1.60$. By mail, postpaid, lb., 25c. Special price in quantity.

English Blue Grass or Meadow Fescue (Festuca Pratensis)-Meadow Fescue is one of the finest perennial grasses grown in America. It is a very hardy grass, producing an abundance of foliage leaves much broader than ordinary Blue Grass, much thicker and containing considerable more fattening qualities. It is very hardy in the South, and is about the only grass outside of Bermuda that seems to thrive, even in hot, dry weather. The soil best adapted for the successful growth of Meadow Fescue is any class of soil that will grow successfully other grasses or crops of grain. In preparing the soil for a crop of Meadow Fescue, it will be necessary that the soil be stirred well and made fine by cross-harrowing. This preparation should ensure whether it is sown by itself or whether it is sown with other grass mixtures. The seed should be sown broadcast on a freshly prepared seed bed and covered lightly with a harrow. Still, since it is a hardy germinator, it will come up if planted much deeper than some other grasses. The quantity of seed to sow an acre depends somewhat on the quality of the seed. It may be safe to set down the correct quantity at two bushels, or say fifty pounds. This quantity applies, of course, when it is sown by itself, but if it be sown with winter grain or other grass mixtures, much less, of course, will have to be used.

The proper time to sow Meadow Fescue, especially

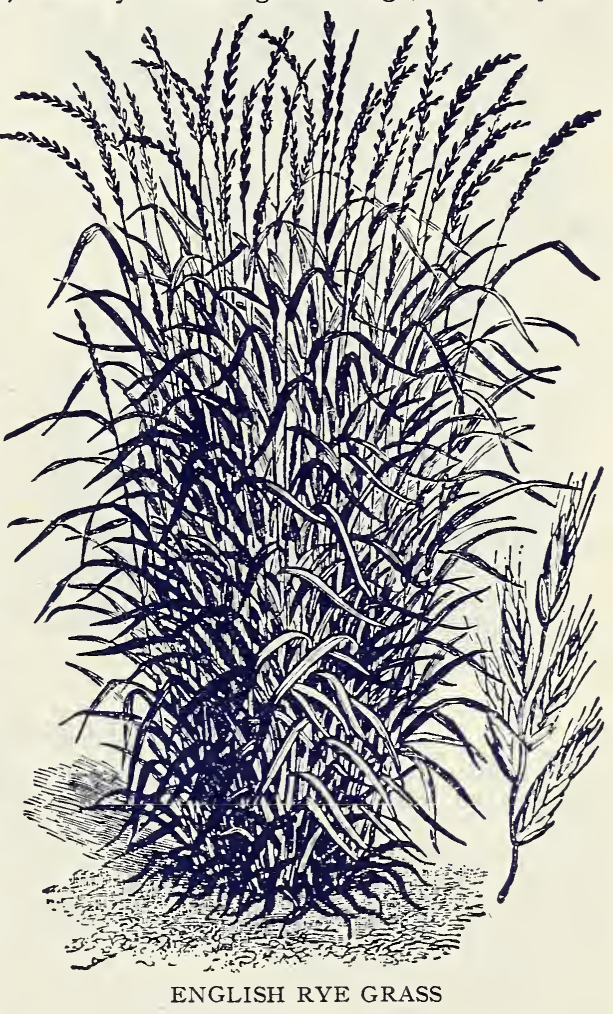
in Alabama, is undoubtedly in the fall of the year;

still, much more is planted in spring. The roots of this grass penetrate to twelve or fifteen inches into the soil, hence its ability to stand dry weather and drouth. The proper time to cut this grass for hay is when it is in full bloom and the head stalk is beginning to turn a straw color. A thick stand of this grass will ordinarily yield three tons of valuable hay to the acre. We strongly recommend its use to the farmers in Alabama. Price of seed, 1b., 20c; by mail, postpaid, lb., 30c. Write for price in quantity

Rhode Island Bent (Agrostis Canina)-This grass is very much like Red Top or Herds, and may be handled in the same manner. It is more creeping and recumbent in its character than Red Top, of somewhat finer texture, and on account of being a rapid grower is much used in lawn mixtures. There is nothing better for damp, wet situations. Price, 1b., 35c; by mail, postpaid, $1 \mathrm{~b} ., 45 \mathrm{c}$.

Creeping Bent (Agrostis Stolonifera)-This grass is very much like Rhode Island Bent and Herds Grass. It is a very quick grower, low creeping in character, and consequently valuable as a soil and sand binder. Valuable for sowing on embankments, terraces, etc., to prevent washing. Largely used in lawn mixtures for the carpet-like effect it gives to grass mixtures. Price, 1b., 35c; by mail, postpaid, lb., $45 \mathrm{c}$

Awnless Brome (Bromus Inermis) - A rapid growing perennial grass suitable in the South for either hay or pasture, but we are inclined to believe that its greatest mission in the South is for a winter pasture. It will stand extremes of cold as well as drouth, and since it is a rapid grower, ought to be of much value to the Southern farmer. The soil for this grass should be prepared in the same manner as for Orchard Grass, and at least 30 to 40 pounds of seed used in seeding an acre. Price, 1b., 15c; by mail, postpaid, $25 \mathrm{c}$.

Grass and Pasture Mixtures-If interested in these, refer to page 47. You will find a valuable list of formulas as a guide to go by. 


\section{Grasses-Continued}

Kentucky Blue Grass (Poa Pratensis)-The most valuable pasture grass in existence in sections of the United States where conditions seem to be right for its successful growth, but south of Tennessee and Kentucky it is not always a success. The cause of this is not clearly understood, but it is usually

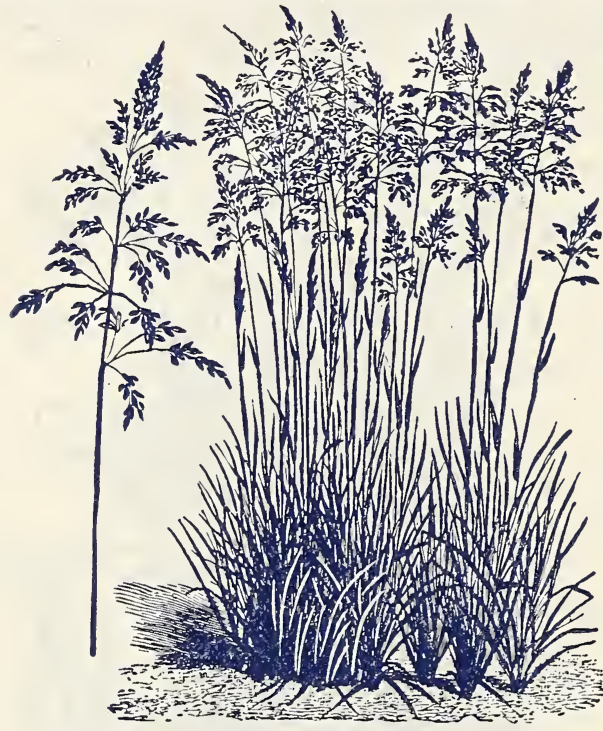

KENTUCKY BLUE GRASS supposed to be due to deficiency of soluble lime. It is known at least that in Alabama Blue Grass does not seem to root deep enough to enable it to withstand a long dry, hot spell in August. A great deal of Blue Grass is used in Alabama for lawns in cities, where it is possible to keep it watered during the dry periods. This grass is used also with success in grass mixtures sown for permanent pastures. Soil must be rich to grow Blue Grass, and must have been properly prepared by deep plowing and thorough pulverization. Blue Grass should always be sown in the fall of the year or very early spring. The quantity of seed necessary is not less than thirty to forty pounds of the best quality to the acre. The seed, after sowing, must be covered very lightly, and ought always to be rolled. A top dressing of bone meal will be found very advantageous every season. Price, fancy cleaned seed, lb., 20c; by mail, postpaid, lb., 30c. Write for prices in quantity.

Rescue or Schrader's Grass (Bromus Nnioloides)-Our seed stock of this grass is the genuine Rescue Grass-Bromus Unioloides. This grass is often confused with Arctic Grass-Bromus Secalinus-which is nothing more than a common cheat. Rescue Grass is one of the most valuable grasses for winter pasture than can be grown in the South. Price of seed, lb., 20 c; 15 to 30 lbs., 16c per lb.; 100 lbs., 15 c per lb.; by mail, postpaid, lb., 30c.

\section{Evergreen Lawn Grass}

Seed-To know what to plant-in other words, the seed-is the first thing to be considered. There is no one grass that will produce a satisfactory lawn in the South by itself. Consequently a mixture is the only thing that may be depended upon. We have experimented considerably with making a permanent lawn in the South, and we have finally hit upon a mixture that we consider more desirable than any other. We refer to Godden's Evergreen Lawn Grass Mixture. This mixture contains all the more hardy grasses, in addition to white clover, but those who object to white clover can obtain our mixture without it. It is permanent in character, and never has to be made over or re-seeded if put in right.

Bermuda a Factor in Southern Lawn Making-We must admit that nothing will stand the hot sun in the South as well as Bermuda, but our Evergreen Lawn Grass will admit of an admixture of Bermuda Grass, although the mixture as supplied by us does not contain any Bermuda, but may be added at the will of the purchaser, at the cost of the Bermuda, and to great benefit. Bermuda is easily propogated from the seed, although the most popular way is through the setting out of roots or by sodding. In making a lawn it's a good idea to sprig with Bermuda, setting a plant or root 8 to 12 inches apart and then sow our lawn mixture over all. You will get quick and permanent results, resulting in green lawn all the year around.

Preparation of the Soil-This is the most important work in connection with the making of a lawn. It is necessary that the soil be thoroughly broken and made as smooth as possible by repeated raking or harrowings. It is necessary to fertilize, and the class of fertilizer used will have a considerable bearing on the finished job. There is nothing better than stable manure, but it should be very old and well decayed to avoid numerous noxious weeds that always come with fresh manure. Street sweepings are used to a large extent for fertilizing lawns, but a fine crop of weeds generally make their appearance. If it is possible to secure good surface soil out of the woods or leaf mould and mix with commercial fertilizers, then better results will obtain.

Commercial Fertilizer for Lawns-We have prepared for us a special high grade ( mmplete fertilizer suitable for lawns, applied as a top dressing or to be mixed with the soil in preparations. It's much cheaper than barn yard manure; a sufficient quantity for a small lawn would cost less than the hire of a wagon to haul a load of manure. Then it is not unsightly, and is so much easier to handle.

Sowing the Seed-The best time to make a lawn is in September and October. Still, good. results are had when made as late as March. It is necessary to sow the seed very thick, so as to establish a turf that will choke out weeds. We recommend one pound of seed to every three to four hundred square feet. The seed are to be broadcasted on the freshly prepared ground and barely covered, and it is very desirable to roll the ground or press the soil with a spade. the object being to bring the small seed in close contact with the earth to prevent drying out. Price of Evergreen Lawn Grass Seed: Lb., 25c; bu. of 15 lbs., $\$ 3.00$. 


\section{Grasses-Continued}

Orchard Grass (Dactylis Glomerata) - A valuable perennial grass for the South, suitable either for permanent pasture or for hay. Most any soil that will grow a good crop of oats will be suited for Orchard Grass. The soil must be thoroughly prepared, made fine and smooth by harrowing. The seed should be broadcasted and harrowed in and rolled where possible. The proper time of the year to sow Orchard Grass in Alabama is either in early fall or early spring. The quantity of seed for an acre will depend largely on the quality, but no less than two bushels of good seed should be used when it is to be the sole crop. If sown with grass mixtures or other seeds, much less will answer. Orchard Grass should be cut for hay when the seed heads have assumed a light straw color. On good land it should yield two to three tons to the acre. Price, lb., 20c; bu. of $14 \mathrm{lbs} ., \$ 2.50$; by mail, postpaid, lb., 30c.

Tall Meadow Oat Grass (Avena Elatior)-Eleven pounds to the bushel. A tall growing perennial grass, with flat leaves and long narrow panicles. It has proven very hardy in Alabama, and may be sown with success either in the fall or spring. If sown in the fall it will grow to be three or four feet high by June and ready to cut for hay as soon as it blooms. Any good soil will grow Oat Grass, and it does much better where the soil is well prepared; still, it has been shown that it will do well in woodland pastures, where it is not possible to make perfect preparations. Meadow Oat Grass is frequently cut green and fed to stock, and a good stand will yield two to three cuttings a season: producing two or three tons of valuable hay. We are inclined to believe that its chief merits lie in its ability to furnish abundant succulent pasture. About thirty pounds of seed is necessary to seed an acre. Price of seed, lb., 20c; by mail, postpaid, lb., 30c. Timothy (Phleum Pratense)-Forty-five pounds to the bushel. The standard grass in America for hay; used, however, in some sections largely
for pasture. It is a rapid growing annual grass, but may be said to be perennial in its character in some sections. The soil best adapted to Timothy is rich loam, and it does not seem to succeed on thin or sandy soil. Soil that is to be sown to Timotny should be thoroughly prepared before seeding. The proper time of the year to sow Timothy in the South is unquestionably in the fall of the year, still it is grown with more or less success planted in

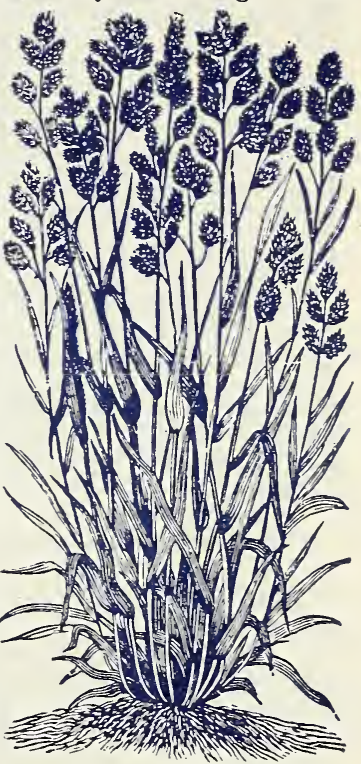

ORCHARD GRASS very early spring. The quantity of seed necessary to seed an acre will d pend on the quality; but where it is to be the sole crop, about fifteen pounds, or one-third of a bushel, should yield a good stand. But, of course, if used in a grass mixture much less should be used. The seed should be sown broadcast on a fresh seed bed and covered very lightly. Timothy usually matures hay in the South by the middle of June, and should be cut when in bloom, before the seed becomes thoroughly ripe. Price of fancy cleaned seed, lb., $1 \tilde{c}$; bu., $45 \mathrm{lbs}$., $\$ 4.50$. By mail, postpaid, lb., 20c. Write for special price.

Johnson Grass-Johnson Grass belongs to the sorghum or cane family, perennial in character, its roots resembling very much the ordinary cane of the bottoms. It is a deep, gross feeder, the roots penetrating very deep in the soil, consequently is a great drouth resister. When Johnson Grass makes its appearance above ground it is very much like young corn or sorghum, grows off rapidly, becoming more spindling, produces a blade like sorghum, only finer. It produces a long branching seed stalk and an abundance of seed. Johnson Grass will grow on most any kind of soil, but the richer the soil the better it grows. It grows very rank in bottoms and on land entirely too wet for most crops. It pays well to make thorough preparation for Johnson Grass. The ground should be broken deeply and made smooth by harrowing.

Johnson Grass is sown very largely both in the fall and spring. If sown in the fall better results are had by sowing with some kind of grain, as wheat, oats, rye or barley. When the grain crop is cut off in the spring, the Johnson Grass will make rapid growth. Such a combination should not be pastured. If sown in the spring results are usually more satisfactory when sown alone. The quantity of seed necessary for an acre will depend altogether on the quality of seed, and it should be noted here that a great deal of the Johnson Grass is entirely worthless. Light, chaffy seed has no vitality; only the black, or partially black, seed will germinate. Only recleaned seed should be sown, and where used alone at least 40 to 50 pounds should be sown broadcast to the acre. But little less with grain, if any, should be used where sown in the fall. Johnson Grass is not profitable where thin. Fall sowings may be harrowed or plowed in lightly on grain, but spring plantings should be covered very lightly. The proper time to harvest for hay is when the plants begin to head. It should not be allowed to mature seed. When well established it can be cut repeatedly if seasonable. The hay is easily cured and without loss of foliage. All classes of live stock are very fond of the hay, and a ready market can always be secured. The yield varies from two to five tons of dry hay to the acre. It should be understood that Johnson Grass is very difficult to eradicate, and where scattered promiscuously over a farm is a great pest, interfering seriously with the cultivation of other crops. Johnson Grass can be confined to any piece of land if not allowed to mature seed, but where stock consume matured seed it will become distributed through droppings of cattle. The best method of eradicating it is by concentrated pasturage with hog or cattle. It may be destroyed by repeated cuttings, because if you don't allow it to go to seed once in two years, it will disappear. Price of seed, lb., 15c; by mail, postpaid, lb., $25 \mathrm{c}$; bu. of 25 lbs., $\$ 3.50$. 


\section{Bermuda Grass}

(Cynodon Dactylon)

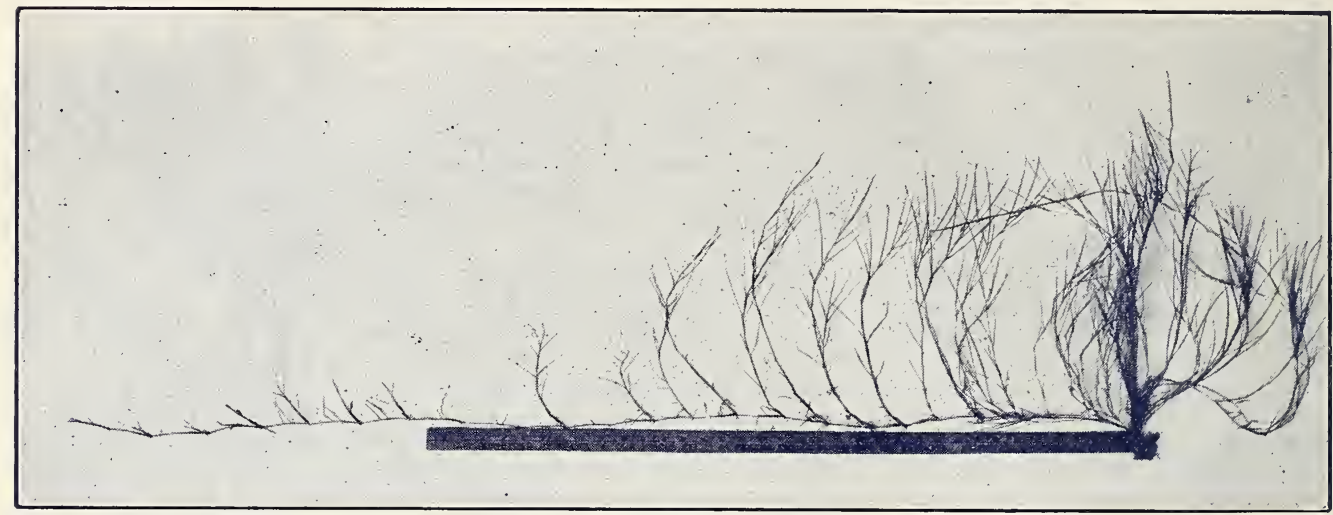

BERMUDA GRASS, SHOWING GROWTH FROM SEED PLANTED IN FEBRUARY-PHOTO TAKEN IN SEPTEMBER quantity.

Price-Fancy cleaned Bermuda Grass Seed, by mail, postpaid, lb., 60c Write for price in

There is no standard weight to the bushel of Bermuda Grass. A measured bushel of recleaned seed will weigh from thirty-five to forty pounds. The seed of Bermuda is small, very much like Timothy in appearance and size. It is perennial in character, creeping in habit, and forms the most perfect sod of any grass. A short time ago this grass was propagated altogether from sets or roots, as it seeds both sparingly and infrequently in the United States. The seed are now imported in this country in great quantities, and are becoming cheap enough to be more economical to plant seed than roots. Bermuda is the South's most valuable pasture grass. It will grow on thin land and stand more hot, dry weather than any other valuable grass. The objection to Bermuda is that it dies down in the winter, but this can be overcome by sowing Bur Clover on Bermuda in the fall of the year. The Bur Clover is a winter growth, protects the Bermuda from freezing out, affords valuable grazing, and disappears in the early spring. Bermuda will succeed fairly well in the South on practically every class of soil, whether poor or rich, but makes ranker growth on good soil. Land to be sown to Bermuda should be prepared well, pulverized and made as smooth as possible. An application of two to four hundred pounds of complete commercial fertilizer to the acre will be of great benefit in giving the young plants a start. Stable manure, will of course, answer, but it should be thoroughly rotten and void of weed seed. From six to ten pounds of seed should be sown to the acre. Bermuda is sown in both the fall and spring. Neither sowing will come up until the weather becomes very warm. Fall sowings are most always made in connection with other grasses-clovers or grain. Such crops are usually harvested by early summer, and give the Bermuda a chance to establish itself. When Bermuda is sown in the spring good results are obtained by sowing alone or with Kentucky Blue Grass. Care must be exercised not to sow in connection with anything in the spring that would create too much shade. Bermuda should be sown on a freshly made seed bed and covered very lightly; rolling after seeding is of great benefit. After it becomes well established no amount of grazing will cause injury. No farmer in the South should be without his Bermuda pasture. Some farmers look upon Bermuda as a pest, and it is where scattered promiscuously over land intended for cultivatiou; but where slight care is exercised the danger of it becoming scattered from roots is reduced to a minimum, and since it does not mature seed to any extent, no danger arises from this source. The chief mission of Bermuda grass in the South is to provide a pasture for all classes of live stock during hot, dry weather, when all other grasses have failed. For this purpose its equal has never been found. Bermuda Grass is much benefitted by working every year or every other year. This is difficult to accomplish, but may be done with a small scooter plow by running a furrow about every fifteen inches apart and then cross-plowing in the same manner. It is sometimes a good idea to fertil ize with barn-yard manure or commercial fertilizer when such workings are given. This working may be done in the fall if you decide to sow Bur Clover. Such plowings will enable the Bur Clover to better take hold. If worked in the spring it ought to be done after all danger of freezes have passed. We find a great many farmers suspicious of Bermuda Grass seed, claiming that it will not germinate. A great deal of fraudulent seed have been palmed off on the farmer in the past, so he has a right to be suspicious. We import, direct, large quantities of gernuine Bermuda Grass seed, test it before selling, and you will not be disappointed if you deal with us. We will gladly send any one a sample to test for themselves.

\section{ARE YOU INTERESTED IN CHICKENS?}

If so, it will pay you to read pages $69,70,71,72,73,74$. Doctor your chickens, feed them, and they will feed you. 


\section{Grasses, Grain, and Forage Plant Mixtures}

Anyone interested will find on this page a list of valuable and suggestive mixtures for different uses. These suggestions are not made up at random, but represent mixtures that have been tried in an experimental way and worked out through repeated field trials, and by men capable of proper management, and correct observation. So many farmers want to sow something of the kind, but, having no experience, don't know how to go about it. A careful reading of the following will be of great help.

Mixture No. 10, Vetches and Wheat-This mixture is composed of $45 \mathrm{lbs}$. Blue Stem smooth head wheat, 15 lbs. true Hairy or Sand Vetch thoroughly mixed, and is sufficient to sow an acre broadcast. The mixture should be sown on well prepared land in September, October or November, and covered about two inches. May be grazed during January and February, and if stock taken off in time will produce a fine crop of hay by May or June. Cut when wheat is in the dough. Price of mixture for one acre, $\$ 3.50$.

Mixture No. 11, Vetch and Winter Turf Oats-Mixture composed of one and a half bushels oats, fifteen pounds Hairy Vetch sufficient for an acre. Sow broadcast during August, September or October, the earlier the better. Cover same as oats. Will afford valuable grazing December, January and February. Can be cut for hay when vetch is in bloom, which generally occurs in March, April or May. Price of mixture for one acre, $\$ 3.50$.

Mixture No. 12, Vetch and Rye-This mixture is composed of three pecks of winter rye and fifteen pounds Hairy Vetch, sufficient for one acre. Plant in the same way and time as vetch and oats, or vetch and wheat. This mixture is more resistent to severe cold than others. Fine for grazing or hay. Price of mixture for acre, $\$ 3.50$.

Mixture No. 13, Vetch and Barley-Mixture composed of one and a half bushels barley and fifteen pounds vetch, sufficient for acre. Sow at same time and in same manner as vetch and oats. Un. usually fine as a grazing proposition for stock or poultry. Price of mixture for one acre, $\$ 4.00$.

Mixture No. 14, Grain Mixture - Mixture composed of one bushel Turf oats, one peck rye and one bushel barley. On good land and where sown in September and October, will afford valuable winter pasture for all classes live stock. Price of mixture for acre, $\$ 2.75$.

Mixture No. 15, Spring Vetch and Burt Oats-This mixture is composed of two bushels Burt oats and twenty pounds spring vetches. Sow in January, February or March. Makes quick and elegant crop of hay of unusual good feeding quality. The vetch puts back more plant food than the oats remove. Price of mixture for acre, $\$ 3.00$.

Mixture No. 16, Canada Peas and Turf Oats-Composed of one and a half bushels Turf oats, one half bushel Canada Field Peas. Sow in September and October. Makes fine winter pasture or valuable hay, and enriches the soil. Price of mixture for one acre, $\$ 3.50$.

Mixture No. 17, Crimson Clover and Oats-Composed of one and a half bushels Turf oats and one peck or fifteen pounds Crimson Clover. Sow in August or September. Affords fine pasture and can be cut for hay in April ond May. The sod from this mixture turned over is fine fertilizer for any crop to follow. Price of mixture for one acre, $\$ 3.50$.

Mixture No. 20, Rape and Barley-Composed of one and a half bushels Barley and five pounds Dwarf Essex Rape. Sow in August, September or October. This formula is especially good for hogs, sheep and poultry to graze, but not suitable for hay. Price of mixture for acre, $\$ 2.50$.

Mixture No. 21, Melilotus and Turf Oats-This mixture is composed of one and a half bushels Turf oats and twenty pounds melilotus. The oats will furnish winter grazing and after cut off for hay or grain the melilotus will come on and make a fine pasture hay, or valuable fertilizer to turn under. Price of mixture for acre, $\$ 3.75$.

\section{MEADOW MIXTURES FOR ONE ACRE}

\section{(Suitable for Hay)}

No. 1. On good land. Neither too wet nor too dry.

7 lbs. Red Top, fancy cleaned.

3 lbs. Tall Meadow Oat Grass.

10 lbs. Orchard Grass.

5 lbs. Perennial Rye Grass.

3 lbs. Timothy.

2 lbs. Alsike Clover.

$\overline{30}$ lbs. Price per acre, $\$ 5.75$.
No. 2. For high and dry land.

7 lbs. Red Top, fancy clean.

5 lbs. Tall Meadow Oat Grass.

10 lbs. Orchard Grass.

5 lbs. Timothy

5 lbs. Meadow Fescue

1 lb. White Clover.

$\overline{33}$ lbs. Price per acre, $\$ 6.50$.
No. 3. On wet, low land. 7 lbs. Red Top.

3 lbs. Creeping Bent Grass.

5 lbs. Orchard Grass.

2 lbs. Tall Meadow Oat Grass.

2 lbs. Meadow Fescue.

8 lbs. Timothy.

3 lbs. Alsike Clover.

$\overline{30}$ lbs. Price per acre, $\$ 6.00$.

PASTURE MIXTURE FOR ONE ACRE

No. 4. On good land, Neither too wet nor too dry.

3 lbs. Tall Meadow Oat Grass.

5 lbs. Red Top.

10 lbs. Orchard Grass.

5 lbs. Perennial Rye Grass.

5 lbs. Kentucky Blue Grass.

2 lbs. White Clover.

30 lbs. Price per acre, $\$ 6.25$.

\section{No. 5. On dry land.}

5 lbs. Creeping Bent Grass.

3 lbs. Tall Meadow Oat Grass.

10 lbs. Orchard Grass.

5 lbs. Timothhy.

5 lbs. Perennial Rye Grass.

2 lbs. White Clover.

$\overline{30}$ lbs. Price per acre, $\$ 6.00$.
No. 6. On wet land

10 lbs. Red Top.

5 lbs. Orchard Grass.

5 lbs. Meadow Fescue.

5 lbs. Timothy.

5 lbs. Kentucky Blue Grass.

2 lbs. Alsike Clover.

32 lbs. Price per acre, $\$ 6.50$.

Write for quantity prices. 


\section{Leguminous Forage Plants}

A leguminous plant is one that has the properties of enriching soil where grown. The roots of such plants are infested with bacteria or colonies of infinitely small micro-organism, which inhabit the modules found distributed on different parts of the roots. These micro-organisms feed upon the roots of such plants, and in turn supply the plani with nitrogen that they are able to assimilate from the air. The importance of plants that store up nitrogen in the soil is now very generally understood. The cow pea is a good example of a legumnious plant.

All leguminous plants will succeed much better if the seed or soil be inoculated. Inoculation may be accomplished in three different ways. First, by using a manufactured article known as Farmogerm (see page 41 for full particulars); second, by removing soil from a field that has successfully produced any legume of the kind you wish to plant, and broadcast such soil, on ground to be planted at the rate of a two-horse load to the acre; third, by growing any legume on soil for two years in_succession.

\section{Soy, or Soja Bean}

A great amount of experimental work has been done in breeding new varieties until there

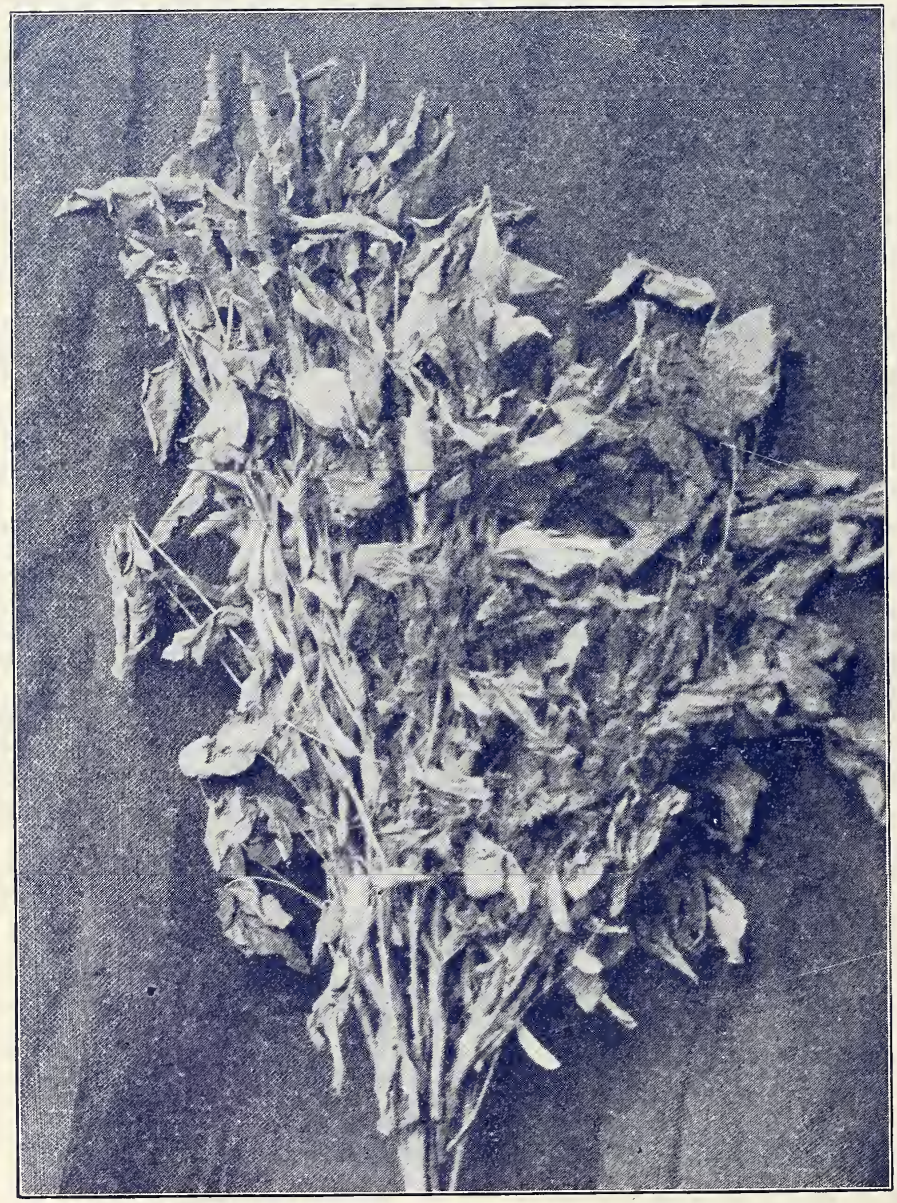

MAMMOTH YELLOW SOY BEAN

is now a considerable list of desirable sorts suitable for most all sections of the United States. The character of growth of the different sorts is very much alike, but they vary widely in time of maturity, and the seed, differing in size, range in color from yellow, pale yellow, brownish white, green and black, and differ in shape from oblong, round, to flat. It is principally used in the South for fertilizing purposes, although considerable of it is made into hay and no small quantity is cut and fed green. The hay is very nutritious as likewise the bean when fully matured. Experience has proven that Soja Beans may be planted in like manner and at any time one would plant cow peas. Soja Beans, however, are mostly planted in drills and given some cultivation. They are rarely ever sown broadcast. The vines are bushy and vigorous, entirely self-supporting. The beans have been dried and used as a substitute for coffee, where they also get the name of "Coffee Bean."

The plant possesses many advantages over the covi peas in that the hay is more easily harvested, more nutritious, more easily cured, and will yield a heavier crop of seed. They will not thrive on as poor soil as cow peas and are not as valuable a fertilizer, nor is the seed of Soja Bean in the same class as the cow peas as a food for man. It should be understood, though, that Soja Beans are leguminous plants and enrich the soil through the work of bacteria on its root system.

Mammoth Southern Yellow-Our experiments have shown this variety more desirable for the South than any other sort. It makes the heaviest growth of foliage, more resistant to drouth and disease, and decidedly the heaviest yielder of grain. It is one of the latest in maturity. Pt., 10c; qt., 15c; pk., 75c; bu., $\$ 2.75$. By mail, postpaid, pt. 20c; qt., 30c. It is best to write for price when ready to buy. 


\section{Leguminous Plants-Continued Vetches}

THE GREAT HAY, FORAGE, AND SOIL RENOVATING PLANT

Hairy Vetches (Vicia Villosa) - There is no standard weight for a bushel. although a measured bushel will weigh about 60 pounds. Several species of Vetches are grown with more or less success in the South, but only one may be planted in the fall of the year with assurance of success. Hairy or Sand Vetch is the true winter Vetch, and takes the place in winter that cow peas do in summer. It is known in some sections as winter cow peas, and is used for every purpose that cow peas are. The seed of Hairy Vetch have a hard shelll, ike okra, but are darker in color, round and not so large. When the plant makes its appearance above ground it resembles somewhat an English pea, only the foliage is finer and will will make considerably more vine. The question of suitable soil for Vetch is less important than with most any other crop. It seems to grow successfully anywhere the cow pea thrives, on thin, sandy lands unproductive to cow peas and on lime land where cow peas do not seem to produce a good crop of seed. The preparation necessary for Hairy Vetches will depend on what is desired in the resulting crop. If sown by itself for the production of hay or fertilizing, the soil should be prepared as though you were going to sow wheat or oats. If sown with other grasses or winter grain the preparation necessary for such grasses or grains will answer for the Vetches. Generally speaking, thorough preparations will have great influence on the crop. If Vetch is sown by itself no less than thirty to forty pounds should be used in seeding an acre, but where sown with winter grain, grasses or clover, half this amount will answer. The proper time to sow is from August to November, care being taken to avoid hot, dry weather. The seed are usually broadcasted and harrowed in, but where sown with grain deeper covering may be given without serious danger. No cultivation is given. Vetch will afford bountiful winter grazing for all classes of live stock, either by itself or in connection with winter grains and clovers. It may be made into hay by cutting in the spring when the plants are, in bloom, or just before the seed pods are grown. Care should be exercised in

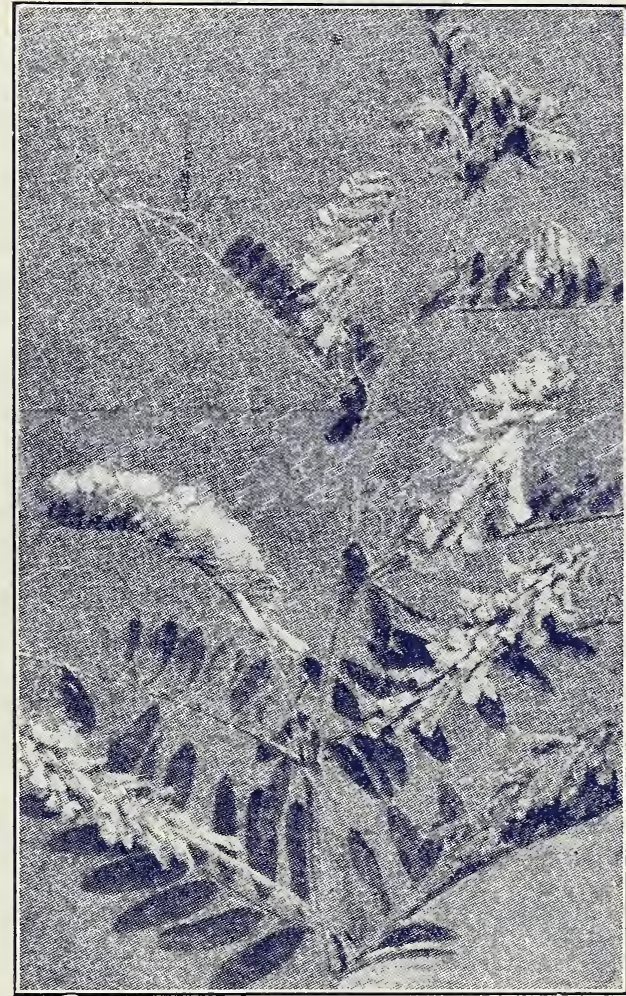

VETCHES

handling the hay to prevent loss of leaves. The feed value of Vetch hay is very high, being equal, pound for pound, with wheat bran; so from this it is easy for the Southern farmer to realize its feed value. Vetch and wheat are a fine combination for the production of hay. It is largely sown also with winter turf oats, rye, barley, crimson and bur clover. It should be understood that Vetches are leguminous plants and enrich the soil where grown in the same manner as do cow peas So it ought to be easy for farmers to realize the great economical importance in their growth. Price of seed, lb., $15 \mathrm{c}$; by mail, postpaid, lb., 25c. Write for special prices in quantity.

Spring Vetches (known also as Winter Vetch and Oregon Winter Vetch)-This type of Vetch is much like Hairy Vetches in character of growth, and is used for the same purposes. It is not so hardy or resistant to cold weather, but in certain sections of the South where the winters are very mild it is used in preference to the Hairy Vetch. The seed of Spring Vetches are much larger than the Hairy Vetch, not so round, being more flat and a lighter shade of color. They are planted both in the fall and early spring, either by themselves or in connection with winter grain, grasses or clovers. The same general directions given for Hairy Vetch will answer for Spring Vetches. Lb., 10c; by mail, postpaid, lb., 20c.

\section{SPECIAL INFORMATION ABOUT VETCH}

One peculiarity of all types of Vetches is that very frequently the first year they are tried on a certain piece of land, either a poor stand or feeble growth will be made and thus discourage a farmer from trying it again. Now, if this same piece of land be sown to Vetch the second year, much better results will be obtained and much finer growth will be manifested the third year on the same ground, and so on. Such failures are generally attributed to the seed, which, in nine cases out of ten, is not so, but is due to the absence of the proper bacteria, and needs inoculation. 


\section{THE PLAIN TRUTH ABOUT SEED MCVAY SEED AND FLORAL COMPANY \\ BIR MING HAM, A LA BA MA}

\section{Leguminous Plants-Continued Florida Velvet Bean}

This is a wonderfully vigorous growing leguminous forage plant, possessing great value as a fertilizer plant. It is an enormous runner, vines sometimes go 40 and 50 feet. While it is of

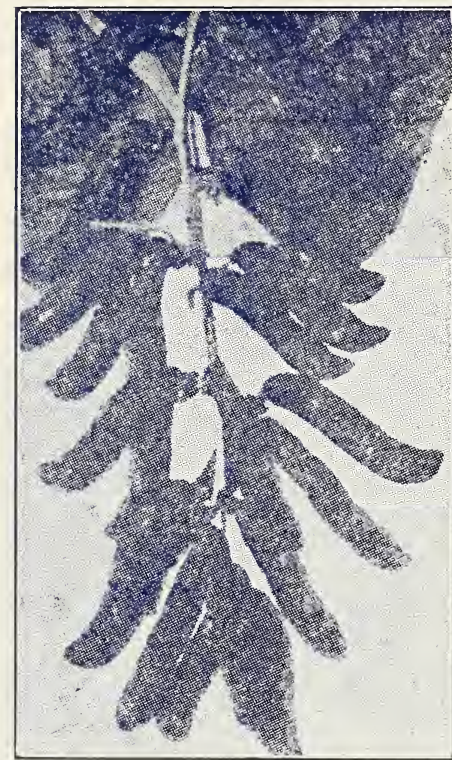

VELVET BEAN rapid growth, forming a dense mass of foliage, yet it is late in maturing, and should not be planted very early in the spring because the seed won't grow until the soil is warm. This is possibly the greatest soil enricher known. It produces an excellent quality of hay but on account of its dense and enormous growth it is very difficult to harvest or cure, and it is practically impossible to undertake to turn a crop under. When wanted as a fertilizer, the best plan is to leave the crop to rot on the ground and then, if desirable, turn under in winter or early spring. The greatest use of this plant in Florida is grazing and fattening cattle, the stock being turned into the fields in the fall of the year and thrive on the mass of leaves, vines and pods until entirely destroyed by heavy freezes.

The beans are generally planted in rows about five feet apart, dropping the beans about a foot apart in the rows, requiring only about a peck of seed to the acre. They are sometimes sown broadcast at the rate of a bushel seed to the acre. For planting around arbors, porches, to cover fences or old dead trees, it is without equal as a beautifiul climber. The leaves are broad, long, pointed rounded in outline and the plant produces great banana like clusters of purplish flowers, followed by huge bunches of pods covered with black downy-like hairs. The seed are about the size of a wren's egg, almost round, slightly flattened, color gray, splotched and striped with light to dark brown. Price, pt., 10c; qt., 2 c; pk., $\$ 1.00 ;$ bu., $\$ 3.50$. By mail, postpaid, pt., 20c; qt., 35c. Better write for prices when ready to buy. We expect cheaper prices.

\section{Canada Field Peas}

This pea in appearance resembles a small extra early garden pea. The plant is not so resistant to hot weather as the cow pea, but it is very resistant to cold weather-in fact, it will stand most any temperature in the South. Consequently it is a valuable hay and forage plant for the Southern farmer, mainly because it grows at a time of the year when the cow pea will not thrive. The Canada Field Pea may be planted in the South any time from September until March. Better success is generally had by planting in the early fall, after all danger of dry, hot weather has passed. They can be sown alone, broadcast like cow peas, at the rate of a bushel to a bushel and a half to the acre and will afford fine grazing within ninety days after sowing, or, if allowed to mature, will produce a valuable crop of hay of very high feed value. The vines are generally cut for hay when the pods are about half grown.

Canada Field Peas are beginning to be largely sown in the South in the fall of the year in connection with such winter grains as wheat, oats, rye, and barley. When sown with grain about one-half bushel of peas are used to the acre, together with about fifty to seventy-five per cent. of the ordinary amount of grain sown to the acre where nothing is mixed with the grain. This mixture can be either grazed or grazed lightly and allow the crop to mature in the early spring and both cut and cured for hay.

It should be understood that Canada Peas are a leguminous forage plant, and enrich the ground in the same manner as the cow pea. So they are frequently sown and turned under for a green maturing crop. Price pt., 10c; qt., 15c; pk., $\$ 1.00$; bu., $\$ 3.75$. By mail, postpaid, pt., 20c; qt., 30c.

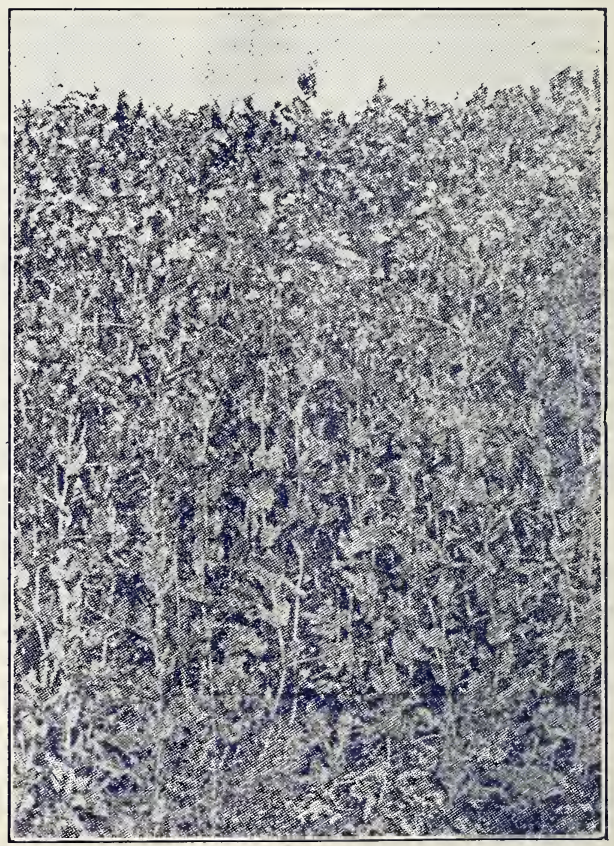

CANADA PEAS 


\section{Leguminous Plants-Continued}

\section{Peanuts}

Peanuts are getting to be one of the most important crops in the South. The increase in acreage is especially noted in sections where the boll weevil prevails. It is not generally understood that the peanut is a leguminous plant and build up the soil in like manner as cow peas, and its worth as a forage and hay plant is not fully appreciated. The demand for peanuts is growing rapidly, not only for a food for man and beast, but a number of products are now being manufactured from them, such as peanut oil, peanut butter, etc. There is hardly any food product more wholesome or possesses a higher feed value. The vines or tops of all sorts of peanuts makes a most delicious hay, relished by all classes of live stock as well as hogs. The hay is much improved where more or less of the nuts are harvested with it.

Spanish Peanuts-There are several types of Spanish Peanuts. One is a large improved sort, another has red nuts, but the one most in use is the common Spanish Peanut, the shell being small, the nuts closely packed in the shell, and are of a pale red or white color. The latter is generally the only variety of Spanish we can furnish. The plant is bunch in character, admits of close cultivation, the nuts are born close to the plant, and when the plant is pulled up most of the nuts adhere to the roots. It is the best flavored nut in use. Price: Qt., 10c; pk., 60c; bu., $\$ 2.00$. By mail, post-

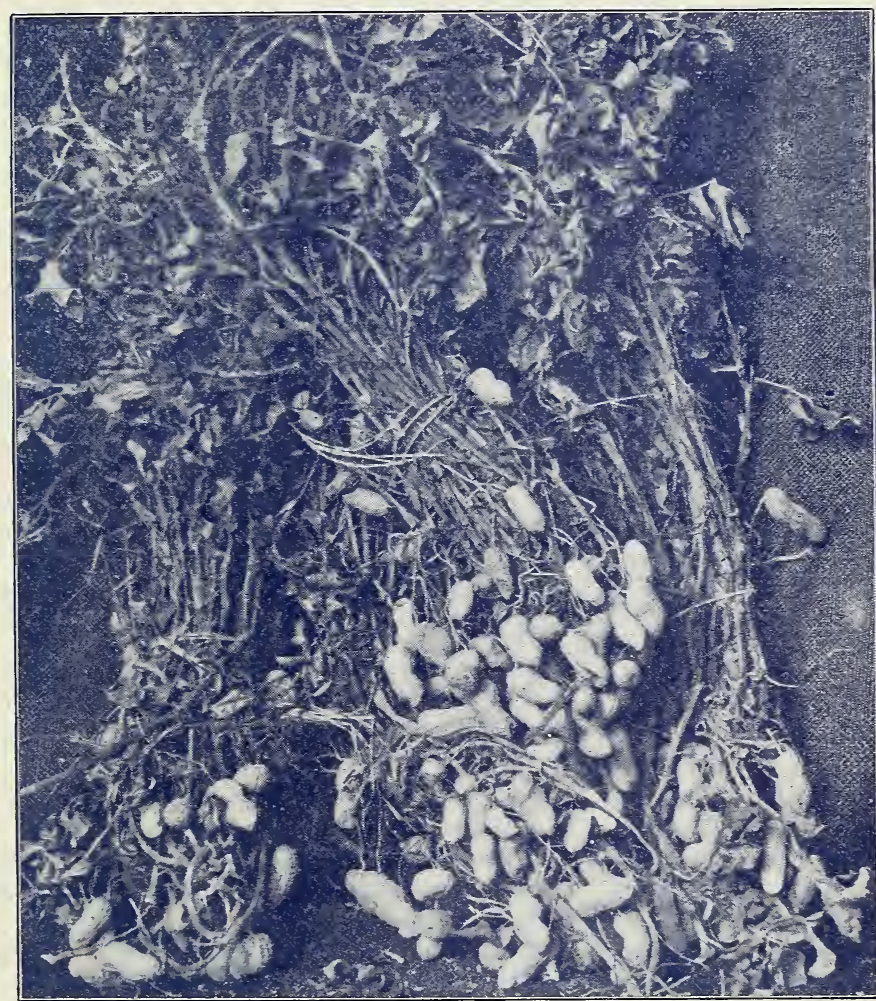

PEANUTS paid, qt., 20c.

Large Red Peanuts-A popular sort in Tennessee and other Southern sections. The peanuts are long, irregular or crooked in shape, and contain from three to five nuts of deep red skin and of splendid flavor. The variety is running and somewhat late, and should be planted on good soil in order to fill out well. For home consumption it is the very best. Price: Qt., $15 \mathrm{c} ;$ pk., $75 \mathrm{c}$; bu., $\$ 2.50$. By mail, postpaid, qt., 25c.

North Carolina Peanuts-In appearance this variety looks like the ordinary Virginia Peanut of Commerce only it is much smaller, being only a little larger than the Spanish. The hull contains two nuts, pale red and white. The variety fills out well and will yield better on poor soil than any other sort. The vines are spreading in character, the heaviest yielder, and affording the greatest amount of forage of any sort. For a hog pasture it can't be beat. Price: Qt., 10c; pk., 60c; bu., $\$ 2.00$. By mail, postpaid, qt., $25 \mathrm{c}$.

Jumbo-This is a very large type of the Virginia Peanut, producing on good soil enormous hulls, and when filled out contain two and sometimes three large nuts. This is a fine sort for home consumption, but ought to be planted on good soil for the best results. Price: Qt., 15c; pk., 75c; bu., $\$ 2.75$. By mail, postpaid, qt., 25c.

Virginia-This is the standard sort of commerce, a vigorous grower, splendid yielder, and more largely planted than any other sort. The hull is of good size, as well as the nuts, and the quality is of the very best. Price: Qt., 10c; pk., 60c; bu., $\$ 2.00$. By mail, postpaid, qt., 20 c. 


\section{Leguminous Plants-Continued}

We are large dealers in cow peas, and will buy or sell any quantity. If you have peas to sell, it might pay you to correspond with us. If you want to buy, let us know variety, with quantity, you want and we will quote you. We often have many sorts not listed. Write for complete list.

California Black Eye-An extremely early sort, maturing peas in six or eight weeks. The pea is large, kidney-shaped, has a distinct black eye. It may be called bunch variety, as it does not put out any long runners except when planted in corn. When planted in the open it does not make any runners to amount to anything. It is very productive, yielding from ten to twenty bushels of peas to the acre. Two crops can always be made, and if seasons are favorable, three crops can be taken off the same land in one season, provided the first crop be planted in early April. In quality it surpasses them all. Price: Pt., 10c; qt., 20c; pk., \$1.50. By mail, postpaid, pt., 20c; qt., 35c. Write for prices in quantity.

Unknown or Wonderful-A very vigorous rank growing variety, especially valuable for hay. Price: Pt., 10c; qt., 15c. By mail, postpaid, pt., 20c; qt., 30c. Write for price in quantity.

Clay Pea-The old standard variety, resembling the Unknown, or Wonderful Pea, except the pea is somewhat smaller and more round. Price: Pt., 10c; qt., 15c. Postpaid, pt., 20c; qt., 30c.

Red Ripper-A very productive, vigorous growing sort, and is much earlier than either the Clay or the Unknown. Price: Pt., 10c; qt., 15c. By mail, postpaid, pt., 20c; qt., 30c. Write for price in quantity.

Black-A very fine variety for fertilizing purposes. The pea is much larger than either the Clay or Unknown, and is pure black. Price: Pt., 10c; qt., 15c. By mail, postpaid, pt., 20c; qt., 30c. Write for prices in quantity.

Whippoorwill-The old standard popular sort, bunch in character and very early. It is largely used not only in producing a pea crop, but hay as well: Its chief value lies in the fact that being so early two crops can be grown, or they can be planted late in the season and still mature. Price: Pt., $10 \mathrm{c} ;$ qt., 15c. By mail, postpaid, pt., 20c; qt., 30c. Write for price in quantity.

Mixed Peas-For sowing for hay, pasturage or fertilizing, these are just as good as any. They are more easily obtained and always cheaper. Price: Pt., 10c; qt., 15c. By mail, postpaid, pt., 20c; qt., 30c. Write for price in quantity.

White Black Eye-Late running sort, fine for eating purposes. Price: Pt., 10c; qt., 20c. By mail, postpaid, pt., 20c; qt., 30c. Write for prices iu quantity.

Small White Lady Pea-Late running, prolific sort, very choice as table pea. Price: Pt., 10c; qt., 15c. By mail, postpaid, pt., 20c; qt., 30c. Write for price in quantity.

White Crowder-The most popular sort for table use. Price: Pt., 10c; qt., 15c. By mail, postpaid, pt., 20c; qt., 30c. Write for price in quantity.

White Grey Eye-A vigorous running, medium late sort, of fine eating quality, and the most prolific of any. Price: Pt., 10c; qt., 15c. By mail, postpaid, pt., 20c; qt., 30c. Write for price in quantity.

New Era-An early small blue speckled sort, bunch in character; popular in the North on account of quick maturity. 'Price: Pt., 10c; qt., 15c. By mail, postpaid, pt., 20c; qt., 30c.

Purple Hull-A large, white pea, having a purplish eye, and the hull, when nearly matured, is of purple color. The variety is a runner, very prolific. Price: Pt., 10c; qt., 15c. By mail, postpaid, pt., 20c; qt., 30c.

About Prices-When this catalogue is written, it is impossible to know what prices will be in effect in spring and summer or just what sorts we can supply. It's best to write us in season, and get a list of varieties we can supply, as well as prices.

\section{Giant Beggar Weed}

This is another valuable leguminous forage plant, grown largely in the State of Florida, also other States now; each year its value is better known, not only for fertilizing purposes, but for producing hay as well as green forage. This plant will subsist on very thin, sandy land, attaining a marvelous 1 ank growth where no other vegetation seems to thrive. This is due, of course, to the plant's ability to utilize the free nitrogen of the atmosphere through the work of bacteria on its roots. This plant has renovated and is bringing into cultivation thousands of acres of land in Florida that heretofore were a mer€ waste. The seeds of Beggar Weed should be planted from April to July. It may be sown broadcast like millet, or may be planted in drills. It will ususally grow to the height of two or three feet, and if put on good soil will grow even much higher. Ten to fifteen pounds of seed are usually sown to the acre. Beggar Weed can be used to great advantage in sowing in corn at last plowing. When the corn is harvested the Beggar Weed will afford splendid pasturage for hogs, cows, horses, and other live stock, by which it is much relished and very fattening. It produces excellent hay, but where this is the purpose it is of course necessary to sow in a situation where the hay can be cut. Write for price of seed in quantity. Price of seed: Lb., 50c. By mail, postpaid, clean seed, 1b., 60c. 


\section{Dwarf Essex Rape ${ }_{\substack{(\text { Barasica } \\ \text { Napus }}}^{(\text {a }}$}

The seed of rape in appearance is just like an ordinary turnip seed, and it might be said that they may be planted in the same manner as turnips and in any month in the year in which turnips may be sown. But since rape is a hardy plant, in fact a cold weather plant, experiments have shown that it will only be profitable to sow this plant in Alabama in the fall of the year or early spring. Rape is a very gross feeder, consequently it should always be planted on extra good soil to obtain the best results, but since it is to be used exclusively for a green pasture practically little loss of plant food will be experienced, as the stock will return practically all of the plant food that has been taken up from the soil. The ground should be prepared by deep plowing, pulverized well, and the seed should be put in to about the same depth as turnips, or one inch, and where practical the ground should be rolled. The seed germinate quickly, and when just above the ground they look identical with ruta baga turnips, but will grow off more rapidly, soon become erect, and throw out numerous branches from the main stalk. It is available for pasture usually in about six weeks after sowing, and when eaten down, spring up very rapidly and afford a long duration of excellent pasture. When stock are first turned in on rape they will not take to it quickly, but they will soon acquire a liking for it and will eat it ravenously. Care must be taken at first not to allow stock to remain on rape too long, as when they eat to excess it is very liable to produce bloating. It is best to start with to turn the cattle on it only about an hour or two, and that in the middle of the day, when the stock are not very hungry, and when the dew is off the plants, because when the plants are wet the danger from bloating is largely increased. The quantity of seed to plant an acre will depend somewhat on what is desired in the pasture, but usually from five to eight pounds of seed, when broadcasted, will yield a sufficient stand, but when it is drilled and workings are

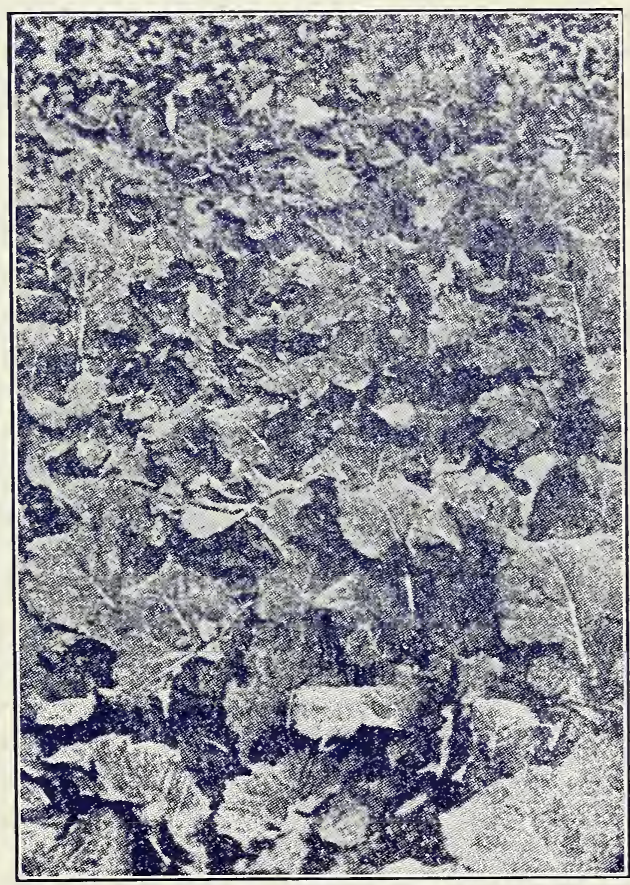

DWARF ESSEX RAPE It is frequently planted in drills and cut for green food for all classes of live stock during the winter. All classes of stock do well on rape, but it is especially valuable for hogs and poultry, and furnishes the greatest quantity of forage at the least cost of anything that we know of. Dwarf Essex Rape is largely planted by market gardeners who cultivate it in drills, bunch it and sell for greens or more often for collards, which it greatly resembles and is splendid for the home table. Price, pound, $15 \mathrm{c}$. By mail, postpaid, pound, 2 c. Write for price in quantity.

\section{Seed Sowers}

Every farmer ought to have a hand broadcast seed sower. They are easy to operate, simply by turning a crank, and they have a guage for different size and weight of seed, so one can regulate the quantity for an acre. You distribute the seed more uniform, better stands result and the saving of seed alone in a few hours use will more than pay for the sower, which will last for years if taken care of. These little machines are the thing to sow wheat, rye, barley, oats, rape, cow peas, clovers, grass, sorghum seed, in fact practically all seed.

Pierce-Cahoon Broadcast Seed Sower, for Sowing Seed Grain, Clover Seed, Ets.-The best seeder manufactured, and sows all kinds of grain, clover seeds, grass seeds, millet, cow peas, sorghum, etc., rapidly and evenly. A person entirely unused to seeding can, by following the simple directions sent with machine, sow from four to six acres an hour at a common walking gait. It sows more uniformly and saves four-fifths in labor by its use. Every farmer should have one of these sowers. Circulars giving full information and directions for use, mailed on application. Price, $\$ 3.00$ each.

Perfect Broadcast Seed Sower-Malleable iron frame, to which steel base is firmly attached, makes a strong seeder, impossible to warp or get out of order from ordinary usage. Will sow wheat, cow peas and sorghum 50 feet at a round; buckwheat 45 feet; flax, clover, timothy and millet, 30 to 60 feet; grass seed 15 to 30 feet, and in fact all seed sown broadcast; also fertilizer ashes. Price, each, $\$ 1.50$.

Cyclone Seeder-This is one of the simplest and best cheap seeders on the market. It is very useful on any farm, and where any seed are to be sown will pay for itself in one day. Will sow wheat, rye, barley, sorghum, buckwheat, alfalfa, clover, millet, turnips, rape and in fact practically all seed, Easilv adjusted to the different seed. Full directions accompany each machine. Price, each, $\$ 1.50^{\circ}$. 


\section{Miscellaneous Plants Buckwheat}

This plant is not as extensively grown in the South as it should be, for it has been demonstrate d that it can be successfully grown in nearly every Southern state where grain crops are grown, and can be made a profitable crop for the flour, while its principal use has only been to furnish a pasture for bees, for which it is excellent. We handle the two varieties named below, which are considered the best. Sow one bushel broadcast in May to July per acre. Weight, 52 lbs. per bushel.

Japanese-Is earlier than the Silver Hull, more productive and does not require as much per acre. Price $-1 \mathrm{lb} ., 10 \mathrm{c}$; peck, $75 \mathrm{c}$; bushel, $\$ 2.5 \mathrm{~J}$. If by mail, postpaid, $1 \mathrm{lb} ., 20 \mathrm{c}$.

Silver Hull-The grain of this variety is a beautiful light gray color, and is being preferred for flour. It blooms much longer than other varieties and is being highly prized by bee raisers. Price-1 lb., $10 \mathrm{c}$; peck, $75 \mathrm{c}$; bushel, $\$ 2.50$. If by mail, $1 \mathrm{lb} ., 20 \mathrm{c}$.

\section{Speltz, or Emmer}

We reprint below an extract from Northrop, King \& Co., of Minneapolis, Minn. We are selling quantities of this in the South with great satisfaction. In the South the seed can be planted in fall or early spring as it is perfectly hardy.

In methods of cultivation this is probably the least exacting of all cereals. It should be sown very early, and this can safely be done, as it is not easily harmed by, and easily resists early and severe frosts, as well as heat and drouth. It should be drilled in at the rate of two bushels to the acre.

"I am very glad to tell you anything I know about Speltz. First, it is a crop on which farmers can rely, as it greatly out yields any other grain. Second, it is unequaled as feed for any kind of stock, as its nutritious shuck, inclosing two kernels of incomparable richness, makes feed that is hard to equal for any kind of 'stock and expecially for working teams. Third, the straw is second to none as a 'gobetween' hay and corn. One acre of Speltz will produce three times the value of produce of wheat, barley or oats. As an example, from a field of wheat of twenty acres grown during the past season by my son, he realized $\$ 60.00$; and from twenty acres of Speltz adjoining it he raised and sold $\$ 240.00$ worth. Speltz is a surer crop than oats, barley or wheat; no crinkling down so that the heads are cut off and fall on the ground, no rust or smut to shrink and make light the berry or lower the grade of the grain. It is conceded by all who have raised and fed it to be the best stock food of any of the family of grains. about here at advanced prices. Farmers are going to sow less wheat, oats and barley, and more Speltz this year. The above is the prevailing sentiment in this section on the Speltz question, and you cannot recommend it too highly."

Price-1 lb., 10c; by mail, postpaid, $1 \mathrm{lb}$, 20c. Write for price in season, as it is impossible to know the price at time this is written.

\section{Broom Corn}

Improved Evergreen-This is the best variety for the South. In diversifying your crops, you will find this a good profitable crop to try, for much interest is being manifested by Southern farmers in the growth of broom corn brush for the market. Parties who have made the experiment report a very profitable business, as there is unlimited demand for good brush at a very high price. To grow broom corn successfully, the ground should be rich and well prepared. Plant seed in rows 3 to $31 / 2$ feet apart and thin to 6 or 8 inches in drill. The plants should be cultivated as soon as they are out of the ground. Harvesting should be done when the seed are in a soft, milky condition. Grow about 8 to 10 feet high. Plant 10 to 15 lbs. to an acre. Price-1 lb., 10c; 100 lbs., $\$ 6.00$. By mail, postpaid, lb., 20c.

\section{Upland Rice}

There is big money in growing Upland Rice, and if you will order a small quantity you will be astonished at the results. The upland sort is very much like the lowland rice in growth, but it is a type that grows well on upland. It should be planted in drills and cultivated like peas and beans. Should be cut when ripe and stored same as oats or wheat. It possesses very high feed value, and is largely eaten by all classes of stock, fowls, etc. Price of seed-By mail, postpaid, qt., 20c; by express or freight, pk., $\$ 1.00 ;$ bu., $\$ 3.50$.

\section{Russian Sunflower}

Growing to double the size of the common sunflower and the yield of seed is twice as great. It is highly recommended for poultry - the best egg-producing food known. Price, lb., 10c; by mail, postpaid, lb., 20c.

\section{Chufas, or Earth Almonds}

The Chufas is a species of ground-nut growing near the surface and easily reached. The plant resembles some green forage grass and produces a delicious small nut, resembling the almond in taste and very rich in food-producing matter. They are easily harvested by hogs and chickens. In some sections are largely used for hog pasture, and are considered a very economica, crop for hogs, as the hogs can do the harvesting, and are very fattening. Plant from the middle of March to the first of June in rows three feet apart, dropping three to four chufas about one foot apart. Cover to the depth of two inches. One peck will plant an acre. Price of seed-Qt., 20c; pk., $\$ 1.25$; bu., $\$ 4.50$. By mail, postpaid, qt., 35c. 


\section{Sorghum}

Sorghum-One of the most profitable hay plants that can be grown in the South. If properly handled, nothing produces more wholesome hay. Sorghum may be sown any time from April to middle of August. Two cuttings can always be made, and sometimes three or more if very seasonable. If sown broadcast alone two to three bushels should be used to the acre. If sown with peas one-half of this amount would do. If planted in drills a peck to a half bushel will answer. If grown for syrup only about half a peck is required to the acre. Farmers in growing for syrup will find it profitable to save the seed, as ready sale is always found for them. Sorghum should be cut for hay when it begins to form heads, or can be cut much sooner if smaller stalks are desired. Great care must be exercised in curing to prevent damage or injury from overheating, the object being to prevent the product becoming sour. Sorghum is very exhausting on land, and will not prove profitable on thin land except it be fertilized.

Caution-Some writers claim that Sorghum is not injurious to live stock when green, and it is a fact that it can be fed sparingly, but it is a well known fact that death frequently occurs from eating green Sorghum. No stock should be grazed on it, because it is much safer to cut and feed sparingly. Sorghum is vastly more profitable made into hay, when it affords a most wholesome food.

Japanese Seeded Ribbon Cane-This variety of sorghum is called Seeded Ribbon Cane, because it produces an unusually large stalk, nearly as large as the large sugar cane or ribbon cane, and the stalk grows much taller. It is prolific in juice, and the juice will run higher in sugar than any other sort. It is the heaviest yielder of juice or molasses of any other sort, and an acre will frequently turn out from four to six hundred gallons of molasses. The product is thick and bright and of the same flavor as the large sugar cane. This plant has a sprangle top, bearing seed in a loose branching head, the seed themselves being somewhat smaller than sorghum, lighter and usually covered with a bright red husk. Care should be exercised not to let the plant stand too long before grinding, otherwise the stalk will become pithy and the yield greatly diminished. But, if the plants are cut just as the seed become mature, it will far outyield any other sort. For the production of molasses we consider it by far the most valuable sort on our list. A half peck is plenty for an acre. Plant and cultivate just like Sorghum. Pt., 10c; qt., 15 c; pk., 75 c; bu., $\$ 2.75$. By mail, postpaid, pt., 15c; qt., 25 c. Write for prices in larger quantities.

Early Amber-This variety is not desirable for syrup because it makes a small slim stalk and less juice than any other sort. But it is extremely early in maturity, produces a small stalk, and is the variety mainly used for sowing broadcast for hay. It is planted in the South from April until the first of August, and under favorable conditions will produce from one to three cuttings from the same sowing. The seed, most of them at least, have a black husk. Price of seed-Pt., 5c; qt., 10c; pk., 65c. By mail, post paid, pt., 15 c; qt., 25c. Write for price in quantity.

Orange Sorghum-This variety is used largely for the production of forage or hay, as well as the production of molasses. It is a medium late variety, producing a large heavy stalk; stands up well and contains considerable more juice than the early amber. It makes a fine bright molasses and an

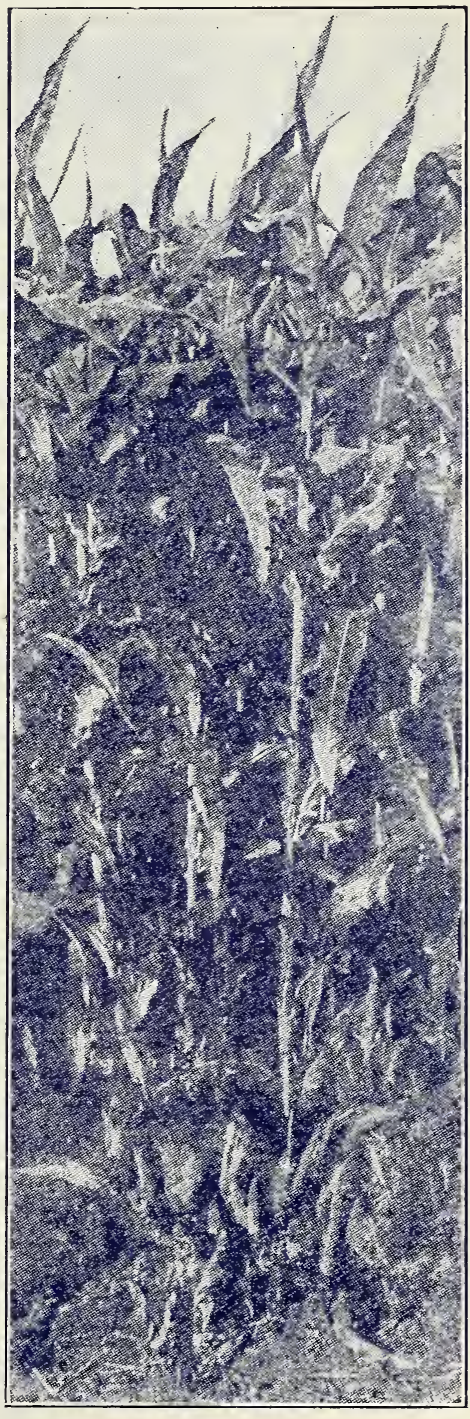

JAPANESE SEEDED RIBBON CANE excellent quality of hay when properly cured. When grown for forage or hay it will produce about $25 \%$ more tonnage to the acre than amber. But the hay, unless sown very thickly, will be somewhat coarser, although sweeter. The seed are large and of golden yellow color. Pt., 5c; qt., 10c; pk., 65c. By mail, postpaid, pt., 15c; qt., 25c. Write for price in quantity

Red Top Sorghum-This is a distinct type of sorghum which is known under various names, such as sumach, negro head, etc. It is later than orange, produces a much larger stalk, does not grow quite so tall, but the plant contains more juice and will afford more molasses to the acre than orange, although the syrup is darker. It is largely planted for both syrup and forage. On account of its yeild as molasses and on account of the heavy tonnage it makes to the acre, and the fact that it does not blow down or fall down as easily as other sorts-when properly cured the hay is excellent. It is largely planted for cutting green and feeding to hogs. The seed are small, almost perfectly round, and of a red color. Price of seed-Pt., 5c; qt., 10c; pk., 75c. By mail, postpaid, pt., 15c. 


\section{Millet Seed}

There are several different types of millet; in fact, the sorghums in some localities are known as millets. But there is a wide difference in the character of growth of the millets that we handle, but all are of considerable importance to the South and their virtues and uses are clearly defined under the separate headings.

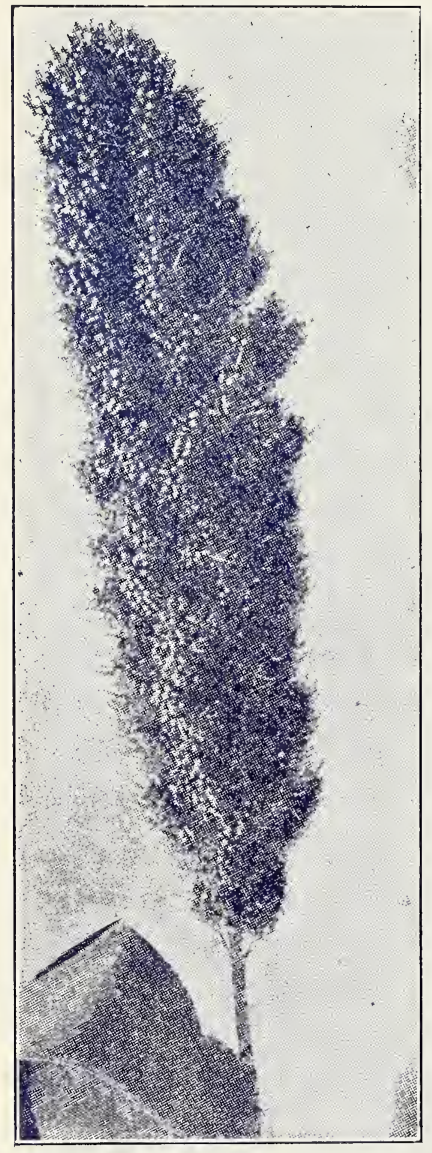

TENNESSEE GERMAN MILLET

Tennessee German Millet-This is the true large-headed, tall German or Golden Millet. On good soil the plants will grow often $4 \frac{1}{2}$ to 5 feet high, producing an abundance of broad leaves and a very large head, and when cut when the head is about half grown, produces a large tonnage of very desirable hay. It is very quick in maturity and is ofter headed out and ready to cut within six weeks after sowing. The seed may be planted any time from April to the middle of August. The hay is very easily cured, and, if cut in the morning, is generally ready to stack late in the evening of the same day. It is very necessary to sow millet on good land for the best results, and at least one bushel should be sown to the acre. The soil should be thoroughly prepared, the seed sown broadcast and covered very lightly. We offer pure southern grown cultivated millet as follows: Pk., 75c. Write for price in quantity.

Pearl or Cat Tail Millet (Horse Millet)-This plant is known under several different names. such as Pencillaria, Manz's Wonderful Forage Plant, etc. There are two or three different types of this plant, but the character of growth of each is practically the same and no distinction is shown in describing the usefulness of this plant. The seed of this plant are small, about twice the size of German Millet, of a yellowish brown or grey color and is of an irregular or pointed shape. The plant is an annual, producing broad foliage very much like sorghum or Teosinte. It is spreading in character and, after being cut, will stool out enormously, of ten producing two dozen or more shoots from the same plant. Its principal use is for cutting and feeding green. It will produce an abundance of fodder which, however, will powder up badly, and it is generally more economical to cut and feed green. It grows very rapidly after getting a start and if seasonable will bear repeated cuttings. The green forage is very nutritious and relished by all classes of live stock. It is particularly valuable for cutting and feeding green to cows and horses from July until frost. It should be sown in drills and cultivated like sorghum or corn, requiring only about five pounds of seed to plant an acre. On good soil it is sometimes sown broadcast at the rate of 30 to 40 pounds to the acre. When this plant matures or heads out it resembles the cat tail of the swa mps. It is often allowed to mature to be cut and shocked for hay, but we believe that its greatest uses is as a green forage plant to be cut and fed green while young. Price of seed-Lb., 15c; by mail, postpaid, 25c. Write for price in large quantities.

Japanese or Barnyard Millet-This is a rapid growing annual millet known in some sections as billion dollar grass. It is a forage plant of great value, producing a luxuriant growth on any a verage soil that will grow corn or cotton. It is frequently cut and fed green as a green forage crop, or it can be made into hay. It is relished by all classes of live stock, and there are no injurious effects from feeding it. The seed may be sown in Alabama from April until August. It is generally sown broadcast at the rate of one bushel to the acre. Price of seed-Lb., 10c; pk., 75c. By mail, postpaid, 1b., 20c.

Teosinte-Sometimes called a continuous cutting forage crop. This is a tall annual closely resembling the common corn in appearance and habit. It also, like Kaffir corn and milo-maize, is a non-saccharine sorghum, but is widely different in habit of growth. It is enormously branching in its growth; a single stalk has been known to bear as many as 60 suckers. The soil best suited for Teosinte is any soil that will produce a good corn crop. It can be cut repeatedly and cured for hay, and when cut will grow out remarkably fast. All classes of stock are very fond of it. Fifty tons of fodder have been made from an acre of Teosinte. Plant in hills 3 to 4 feet apart each way, 2 to 3 seed to a hill; 4 to 5 lbs. of seed will plant an acre. Price-Oz., 10c; 1/4 lb., 25c; lb., 75c, by mail, postpaid. 


\section{THE PLAIN TRUTH ABOUT SEED MEVAY SEED AND FLORAL COMPANY}

\section{Forage Crops for the South}

We list on this page a number of valuable non-saccharine plants that belong to the Sorghum family. They a re great drouth-resisting plants and, thriving when corn and sorghum dry up, and will never fail to make a valuable fodder or hay crop. The hay itself is not so full of nutriment as well cured sorghum, but if the seed are allowed to mature, the hay or stover surpasses sorghum for the reason that the seed itself of the non-saccharine sorghums is excellent feed for man or beast. The Indians in dry regions grow milo-maize instead of corn for bread. In short, the seed of this class of plants is worth far more than the stalk and fodder. The plants should be cultivated in drills like corn, only thicker in rows. On account of this class of plants ability to stand any amount of heat and dry weather, we urge Southern farmers to give them a trial.

\section{Kaffir Corn}

Also called "chicken corn." This is another non-saccharine sorghum. The stalks keep green and are brittle and juicy, not hardening like other varieties of sorghum, making an excellent fodder and is highly relished by all classes of stock, green or dry. The grain is largely used for chicken feed. For grain, sow in rows 3 feet a part, $10 \mathrm{lbs}$. of seed to an acre; for fodder, sow $1 / 2 \mathrm{bu}$. to an acre in drills. There are two varieties, white and red. Often sown broadcast, like sorghum, two bushels to acre.

White Kaffir-The most popular on account of the seed being larger and cheaper. Price-Lb., 20c, by mail postpaid. By express or freight, pk., 60c.

Red Kaffir-Grows taller than the white, seed smaller, ripens earlier, and yield heavier than the white. Lb., 20c, by mail, postpaid; by express or freight, pk., 60c.

Jerusalem Corn-This is claimed by practical growers to be an improvement on the Kaffir Corn. It is a non-saccharine sorghum, and one of the best and surest of the grain crops for dry countries

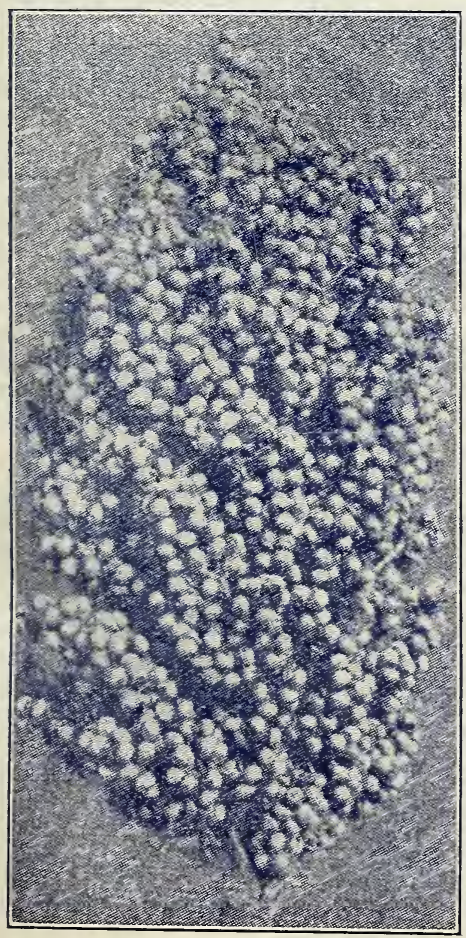

MILO-MAIZE and seasons. It grows from 3 to 5 feet high, makes one large head on main stalk and 3 to 5 on side shoots; grain pure white, nearly flat. Both as a forage and grain crop it is a success. Three to four lbs. will plant an acre in drills; 40 to 50 lbs., broadcast. The heads of this plant are similar in size and shape to those in the milo-maize cut given on this page. Price-1 lb., 15c. Bymail, postpaid, lb., 25c.

Yellow Milo-MaizeThis is probably the most valuable of all the nonsaccharine sorghums and its growth is the West in on an enormous scale, furnishing food for man and

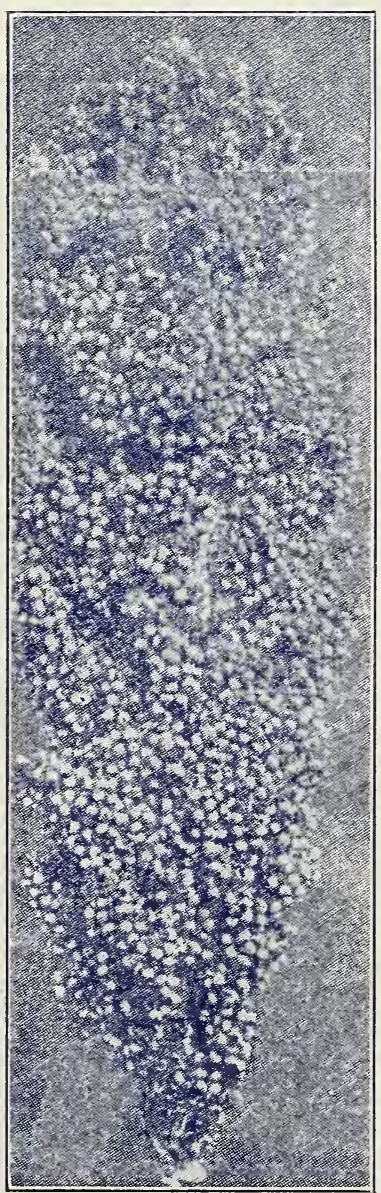

KAFFIR CORN

beast. It produces a growth from nine to twelve feet high and yields from fifty to a hundred bushels of grain to the acre. Its growth and cultivation is very much like sorghum, but sends out shoots from every joint, and of ten single heads will weigh a pound. The plant is branching in habit and rows should be four to five feet apart and thin to two, to two and a half feet apart. The grain is round, twice the size of sorghum, pale yellow color, but pure white inside. The seed are equal to corn for any purpose.

Southern farmers will find this a valuable plant to help out corn crop as it may be planted from March to July and mature a crop under hot, dry conditions where corn would be a failure. A half peck is sufficient to plant an acre in drills. Llb., 10c; by mail, postpaid, lb.,20c. By freight or express pk., 75c. 


\section{Seed Oats}

Burt Oats - The Burt Oat is an extremely early variety, producing an abundance of straw of good length. It is the best poor-land oat known, also the safest and earliest to plant in the spring The grain is small, light, slim, and, under favorable weather conditions, is of a very light straw color. A good per cent. of the grains have beard, and are frequently borne in clusters of two. The genuine Burt Oat is a sure header, coming to maturity ten days to two weeks before rust-proof. A great many common Western white oats are sold for Burt. This occasions no small loss to the Southern farmer, as Western oats are always late and affected with the rust to the extent that they rarely head. Good land of course, will produce Burt Oats better than poor, but on account of this oat's habit to grow tall it may be planted on poor land with fairly satisfactory results. Thorough preparation should be made

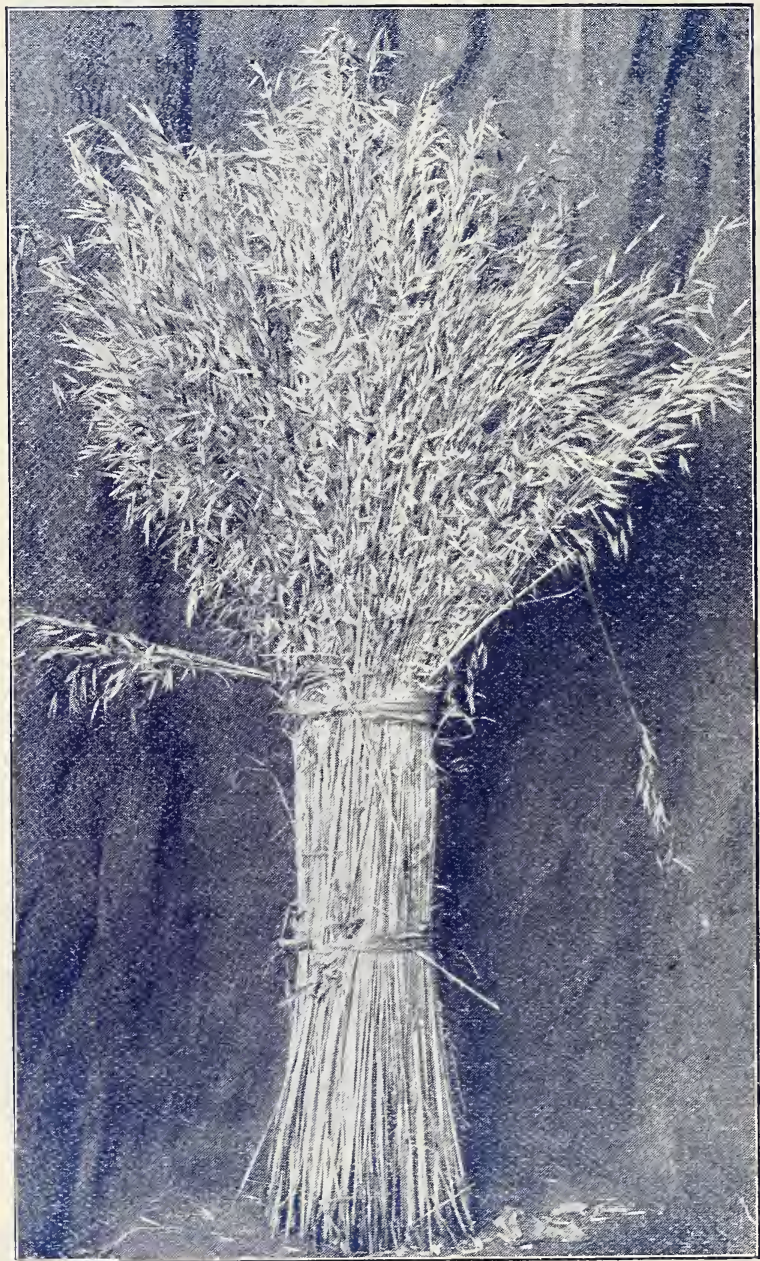

BURT OATS in sowing this oat. No less than two bushels of Burt Oats should be used in seeding an acre, and where they are to be made into hay three bushels will be found profitable. We are selling great quantities of these oats now for fall planting, and when properly put in go through the winter all right and come in extremely early in the following spring. The standard weight of oats is 32 pounds to a bushel. Price, $85 \mathrm{c}$ per bushel. Write for prices in larger quantities.

Appler Oats-This is a Southern grown type of heavy red rust-proof oats, mostly bearded. It is the most resistant variety to rust that is grown in the South. When grown on good land, the grain is very large, red in color, often containing more or less black grains, and will frequently weigh as much as thirty-six to thirty-eight pounds to the measured bushel. It is a tremendous yielder of grain when planted in the fall of the year, and is very often grazed. Fall is undoubtedly the best time to plant this variety. Still they produce a splendid crop sown in the spring, but the grain will not be quite so heavy. They should be sown on good land at the rate of two to two and a half bushels to the acre. Write for price in season.

Winter Turf Oats-This oat is unsuited for spring planting. They are best planted in the fall and will furnish excellent winter and spring pasture. Write us early this fall for prices and samples.

Texas Red Rust Proof OatsStandard weight 32 lbs. to the bushel. There is no better oat than the Red Rust Proof, provided the seed are grown in the state of Texas. It is probably not untrue to say that more than 75 per cent of the oats sold as Texas Rust Proof never grew in that state at all. Farmers should become posted and be more careful in purchasing their seed oats. The Texasgrown oat is a heavy berry, nearly every one having a distinctive beard. The color varies, owing to the seasons; also the weight of a measured bushel. This type of oat should be planted on strong soil. The soil should be broken deeply. They are largely planted in the fall and early spring. At least two bushels should be sown to the acre. We can supply this variety if wanted in car-load lots. Ask us for prices, stating quantity wanted.

Prices on oats fluctuate. We can't guarantee catalogue prices, but will quote special prices by mail.

\section{GRAIN MIXTURES FOR PASTURE AND HAY}

Refer to page 47 , and read carefully about the different mixtures. We give formula. These mixtures will show a new use to which all grains can be put to and at great profit. 


\section{THE PLAIN TRUTH ABOUT SEED MMVVY SEED AND FLORAL COMPANY}

\section{Seed Wheat}

About Prices-We can't tell what seed will be worth at this writing. It will probably be cheaper than last year. Write for definite prices and full list of varieties when ready to buy.

Most of our seed wheat is grown in the State of Tennessee by farmers who make a business of growing distinct sorts for seed purposes. We select farmers who grow only one sort on their farm and are thus able to give us seed unmixed. All our seed wheat is free from smut, or other diseases, thoroughly recleaned and all small or faulty grains blown out, and will be found free, or as nearly so as possible, of cockle.

Some Points About Growing-Most farmers who ever grow any wheat have their own ideas about rational methods of getting profitable yields, and it is hardly worth while to detail here any fixed rule to go by, but a few suggestions, drawn from practice and observation, might be of interest. The explanation for the small yield usually reported in the South can usually be traced to the deficiency in the soil of vegetable matter and the absence of sufficient nitrogen and phosphoric acid, more to this than to an improper method of land preparation, although the latter is highly important to get the full benefit of the plant food available. The Southern farmer has the ideal fertilizer for wheat in the common cow pea, and no other fertilizer he can use is as economical. Besides the plant food stored up in the soil by turning under a heavy crop of pea vines, or through merely growing a crop where it is pastured or cut off, there is a great amount of vegetable matter put in the soil, which is greatly needed by the wheat plant. All wheat land should be sown to cow peas. A good commercial fertilizer is 200 pounds 16 per cent acid phosphate, 200 pounds cotton seed meal, 50 pounds muriate of potash, to be applied to each acre, more or less, as the soil would indicate. Two to four hundred pounds of pure raw bone meal to the acre gives remarkable results.

Blue Stem or Purple Straw-This is more largely planted in Alabama than any other sort. The head is smooth, berry small, short, almost round, and very firm, and makes a fine turnout of excellent flour. It is a rustproof sort because, being extremely early to mature, it will always ripen before danger of rust. It will grow taller on poor soil than many other sorts and makes a splendid yield under proper conditions. Fairly good soil should yield fifteen bushels to the acre. Good soil, properly fertilized, and where the seasons are right, thirty-five to forty bushels to the acre is possible.

Currills Prolific-The head is smooth; grain a small, red berry, firm, and is a most excellent milling wheat. It is a very early sort, heading almost

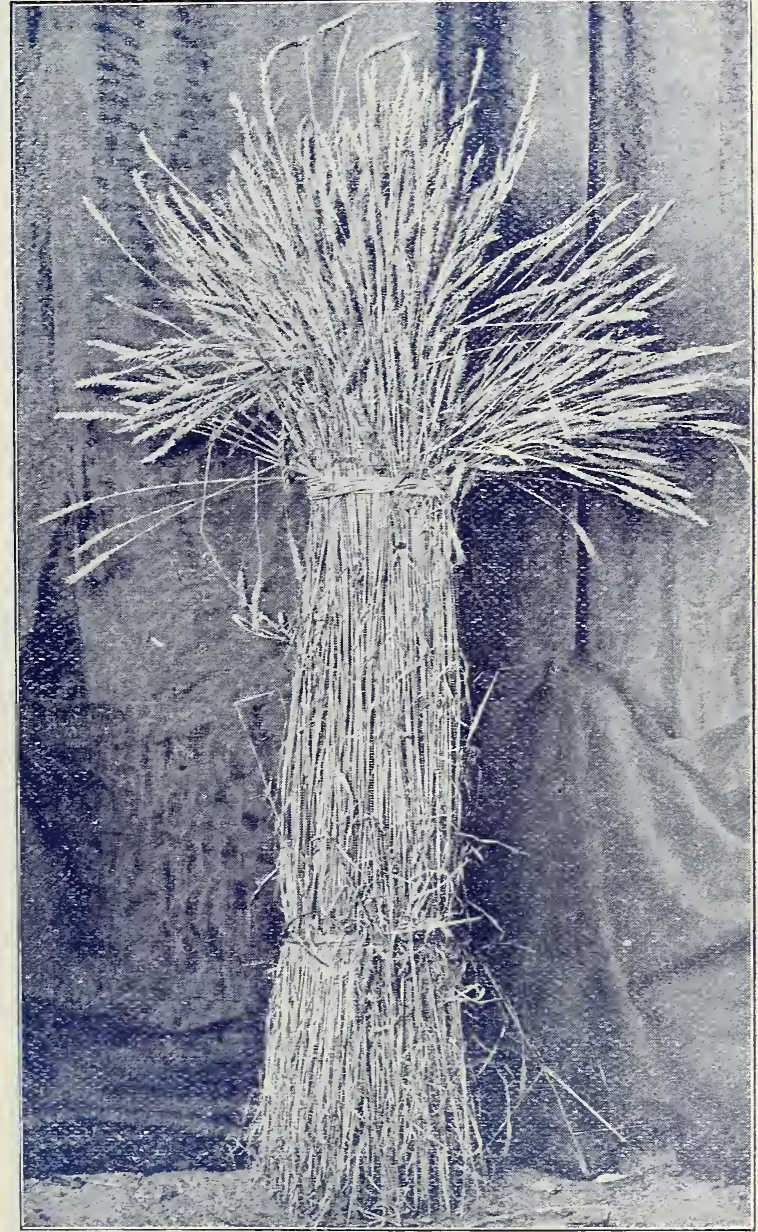

GEORGIA BLUE STEM

at the same time as the blue stem, which puts it out of range of the rust. Under favorable conditions it outyields the blue stem, but does not seem to stand dry weather so well.

Early Red May-A smooth headed variety of long popularity in the South. The variety is early and prolific; the berry small, firm, red and of excellent quality. It is very hardy, being very resistent to disease and the sudden changes peculiar to the South. It ripens almost at the same time as the blue stem and is consequently a rust proof sort.

Fultz-An excellent smooth headed sort, producing a good size grain; very prolific and exceedingly hardy. It is a standard sort over a great section of the North and is largely grown in wheat sections of the South.

Fulcaster Bearded-This is the standard bearded wheat grown in the South. It is a heavier yielder than the smooth headed sorts, and grain much larger. 


\section{Winter Rye}

Rye-Winter Rye still remains the most popular winter grain used in the South. Its use is greatly increasing, until now nearly every Southern farm will have its rye patch. Rye is sown in Alabama from the middle of July until January. Poultry raisers will find rye a valuable crop to furnish green forage during the fall and winter, it will increase the egg production.

Winter Rye (South Georgia Grown)-This is a type of rye grown in South Georgia. It is peculiarly adapted to the latitude in the southern half of the Gulf States. It grows erect and very tall, even on thin land, and is very desirable for grazing or for hay. If it is the purpose to produce hay, a great improvement can be added to the product by sowing with it hairy vetch, using three pecks or a bushel of rye and fifteen to twenty-five pounds of vetch to the acre. When the rye begins to head and before the beard gets tough it should be cut as then the vetch will be in the bloom and the time is correct for the greatest yield and best quality. Price of genuine South Georgia grown rye, bushel, $\$ 2.50$.

Winter Rye (Tennessee or Northern Grown) - This is the hardiest type of rye grown. For latitude north of Birmingham it is better adapted than South Georgia grown, because it will grow just as tall, more spreading in character and decidedly more resistant to severe cold weather; and another important

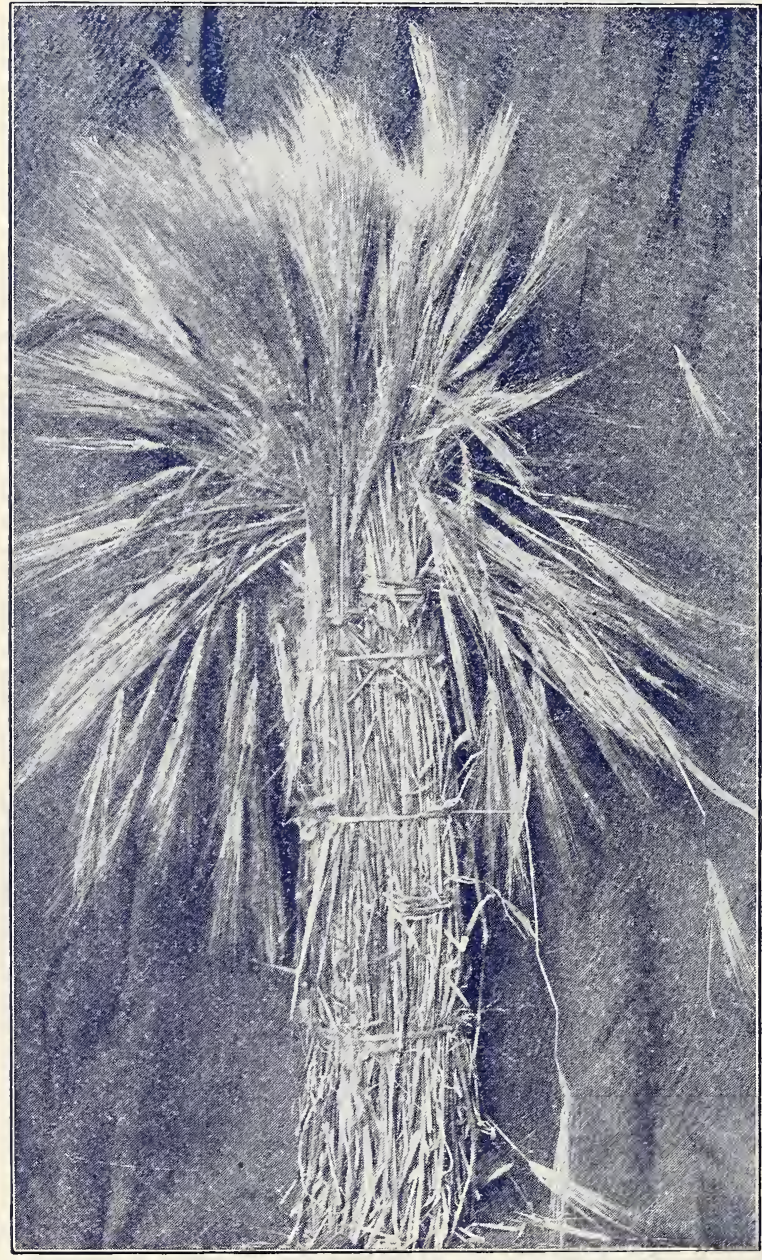

WINTER BARLEY thing the seed cost only about half what the South Georgia product costs. this type of rye is largely used for winter pasture, either by itself or in a grain mixture composed of winter oats, winter barley, etc. This mixture of other grain is very desirable because all classes of live stock will eat it better. Price of Tennessee or Northern, bushel, $\$ 1.50$. Write for price in quantity.

\section{Winter Barley}

Winter Barley (Bearded Variety)Winter Barley is used for every purpose that rye is, and possesses both advantages and disadvantages in comparison to rye. Barley will grow faster than rye, produces more blades and is much more readily eaten by all classes of live stock. Winter barley may be planted in the South from middle of July until December, the earlier the better, expecially where it is intended for a winter pasture. August and September sowings when well fertilized or sown on a rich situation will afford a quantity of grazing by Christmas. When barley is sown alone and intended for grazing we recommend that two bushels be sown to the acre. The same method of planting and preparation used in sowing oats, wheat or rye will answer for barley.

The main factor for a success with barley is the seed itself. Most of the barley offered for seed is northern grown, harvested generally from spring sowing. This is absolutely unfit for the Southern States. We offer only genuine Tennessee grown winter barley from fall sowings. The seed cost more but it never disappoints. Price of seed, bushel, $\$ 1.40$. Write for price in quantity.

\section{Beardless Barley \\ FOR SPRING SOWINGS}

Beardless Barley-This is comparatively a new thing in the South, but growing - into great favor. It is very much like the ordinary barley in grain and growth, but has the peculiarity of having no beard, an advantage alone that is easily seen by the planter. Another thing, it is extremely early and quick in its growth, thus affording a quick grain hay not equalled by the slower growing grains. Beardless barley is more frequently sown in the South in very early spring and will mature as quick as winter barley sown in the fall. It is peculiarly adapted for a quick hay crop, but is not equal to winter barley as a pasture because it does not spread or stool out in the same proportion. We urge everybody to try it. Price of seed, bushel, $\$ 2.00$. 


\section{Cotton Seed}

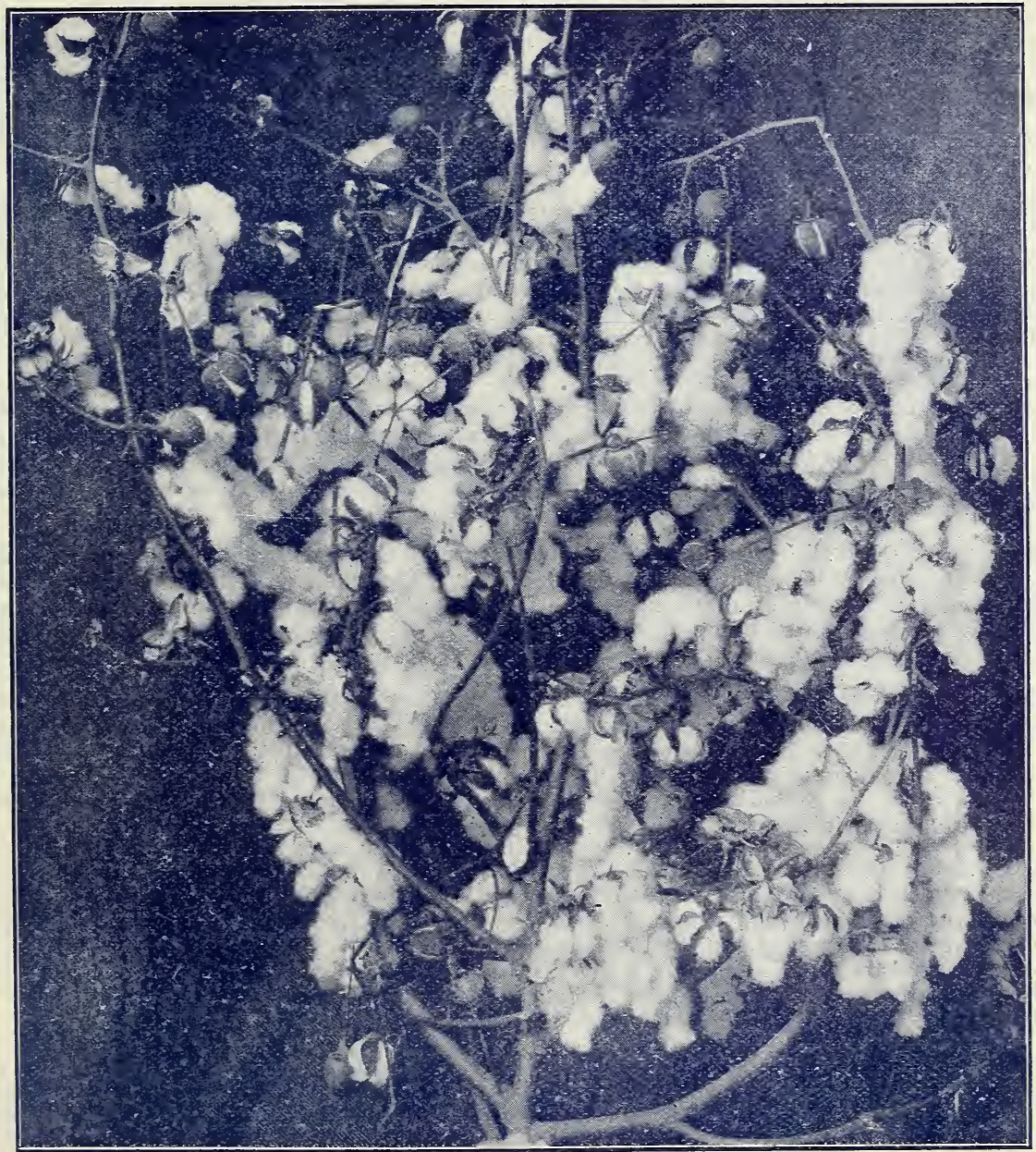

CORLEY'S SNOW BANK

THE PRIZE STALK COTTON, ALABAMA STATE FAIR

BIRMINGHAM, ALA., OCT., 1912

Snow Bank-This variety originated by W. A. Corley, of Coosa County, Ala., who exhibited same in Birmingham at the Alabama State Fair, October, 1912. He took first prize on his exhibit of his cotton on stalk, lint and baled. It was unanimously voted the best short staple cotton exhibited. This sort is a vigorous grower, producing a large stalk of medium height, branching in character and enormously prolific, with no barren limbs. The bolls are of mammoth size, slightly pointed, open out well, containing five locks and only require 50 to 60 to turn out a pound of seed cotton. The per cent of lint will run near to forty per cent and is of the finest, strongest and longest of any short staple sort we have ever seen. The seed are medium to large and mostly white. The variety is very early for a large boll sort. It is easily picked because a good opener, notwithstanding the locks are firmly set, and does not fall out easily. We regret only having a few bushels to offer this season, but we urge our customers to give it a trial and plant it where it can't get mixed, gin separately and you will have your own planting seed another year. Lb., 15c. By mail, postpaid, 1b., 25c. By express or freight, Pk., 75c; bu., $\$ 2.50$. 


\section{Cotton-Continued}

Kings (King's Improved)-The plant of King's is rather small, bearing short base limbs with numerous medium length upper limbs. On part of the blooms there is a red spot usually inside the flower near the base. The main qualities of this variety is its extreme earliness, being earlier than any other known sort. The staple is of fair quality but rather short. The per cent of lint is high, running from $38 \%$ to $40 \%$. The seed are small, fuzzy, mostly greenish white and brownish green. The bolls are round and blunted. It is highly recommended for bottom or late lands. Price of seed-quart, 10c; peck, 40c; bushel, $\$ 1.50$. By mail, postpaid, quart, $20 \mathrm{c}$.

Toole (Toole's Early Prolific)-The plants are of medium size, well supplied with limbs, none of which are barren. The variety is exceedingly prolific, boll small, requiring about eighty to a pound of seed cotton. The bolls are ovate, pointed, containing both four and five locks. The variety opens out very wide, making it exceedingly easy to pick. The seed are very small, white to pale brown, and containing some darker shades of seed. The per cent of lint is very high, often reaching forty per cent. The variety is extremely early, very little behind Kings, but decidedly more productive than Kings. Price of seed-quart, 10c; peck, 50c; bushel, $\$ 1.50$. By mail, postpaid, quart, $20 \mathrm{c}$.

Peterkin (Improved Stock)-The plants are medium to large size and are abundantly supplied with side limbs, short to medium in length. Bolls are medium in size, running about 75 to a pound of seed cotton. In shape the boll is ovate, pointed and opens out very wide. Most bolls will contain as much as five locks. In maturity it is early to medium. Price-Quart, 10c; peck, 50c; bushel, $\$ 1.50$. By mail, postpaid, quart, $20 \mathrm{c}$.

Simpkins (Simpkins Prolific) - The main feature of this variety is its extreme earliness and prolificness. It will generally run forty per cent in lint. The quality of the staple is the very best, boll of good size, stalk medium in size and all of its branches are literally covered with bolls and it is a rare thing to see any of its branches that are barren. Price of seed-Quart, 10c; peck, 50c; bushel, $\$ 1.50$. By mail, postpaid, quart, 20c.

Cook's Improved-The bolls are large, requiring 50 to 60 to turn out a pound of cotton. In shape they are round, blunt and usually contain five locks. The boll opens out very widely and the lint is inclined to fall out. In maturity the variety is early to medium. This variety is very easily picked and the percentage of lint runs very high, averaging 38 to $40 \%$. It is prolific in character and in some sections it is the general favorite for all classes of soil. Price-Quart, 10c; peck, 50c; bushel, $\$ 1.50$. By mail, postpaid, quart, 20c.

Cleveland (Cleveland's Big Boll) - The plant is tall, producing numerous limbs, medium to short lengths, which have an upward or erect tendency. The bolls are very large, requiring 55 to 65 to turn out a pound of seed cotton. Most of the bolls will contain five locks. Bolls open very wide and the variety is very easily picked and the lint is inclined to fall out. The seed are of medium size, fuzzy, white, some being brown and some with a greenish tint. The bolls are round and pointed. In point of maturity the variety is early to medium. In fact, it is one of the earliest of the large boll type. Price: Quart, 10c; peck, 50c; bushel, $\$ 1.50$. By mail, postpaid, quart, 20c.

Truitt's Big Boll-The bolls are unusually large, containing five locks, and from 45 to 55 bolls will generally turn out a pound of seed cotton. The plants are well shaped, symmetrical, branching in character and boils are inclined to be borne in clusters. In shape, the bolls are ovate, pointed and open up very wide and the seed cotton is inclined, sometimes, to fall out. The variety is medium late in maturity. It is especially recommended for up-lands, where commercial fertilizers are used. Quart, 10c; peck, 50c; bushel, $\$ 1.50$.

Triumph (Known also as Mebanes Triumph) - This variety is probably the largest of all the big boll types. Very frequently forty bolls will turn out a pound of cotton. The percentage of lint is very high, running from 38 to $40 \%$. The seed are numerous, medium size, fuzzy, brownish white and some few green seed. The bolls of this variety open out widely, but the lint is firmly set in the boll, making it, to a great extent, a storm proof sort. The stalk is very vigorous in growth, that is, producing a large stalk, but of medium height, short jointed, much foliage, branching in character and very prolific in nature. Price-Quart, $10 \mathrm{c}$; peck, $50 \mathrm{c}$; bushel, $\$ 1.50$. By mail, postpaid, quart, $20 \mathrm{c}$.

Russell (Russell's Big Boll Prolific)-It is, in fact, the original big green seeded variety from which a number of other varieties have sprung. It is, today, considered the standard large boll variety. The plants in size may be considered medium and usually have four base limbs, spreading and of medium length. The upper limbs on the plant are shorter. The foliage is very large and the bolls are unusually large, averaging from 45 to 55 to a pound of seed cotton. In shape, the bolls are long ovate, tapering to a point. The seed are very large, mostly green or greenish brown, but contain a considerable percentage of white seed which gives the variety the appearance of being mixed. Pricequart, 10c; peck, 50c; bushel, $\$ 1.50$. By mail, postpaid, quart, 20c. 


\section{Sweet Peas}

How to Grow-Sweet Peas may be successfully grown in every State in the Union. The soil best adapted to Sweet Peas is a deep, rich loam; still any soils can be made to grow them, providing the right preparations are carried out. The universal method is to dig a trench six to ten inches deep and about a foot wide. The bottom of this trench should be forked up deeply, then filled about half full with thoroughly decayed barnyard manure or leaf mould mixed with manure. If either of the above is not available, good surface soil may be used, but should be made to contain about 10 per cent commercial fertilizer. Cotton seed meal and fresh manure should be avoided. After suitable preparations are made the seed should then be sown thickly in double rows, made about six inches apart. This will enable one to better cultivate.

The proper time to sow Sweet Peas is from December to March; later plantings do not amount to much. When planted they should be covered five to six inches deep, and the trenches in which the rows are made should not be filled more than two-thirds full. When the plants begin to grow off in the early spring the trench may then be filled up with good surface soil or mulching material. Suitable support should be provided as soon as the plants show an inclination to run. When the plants begin to bloom they should be watered copiously each night, and all blooms picked off as fast as they appear. Sweet Peas will stand severe cold weather, and where the tops get killed down, in the latter part of winter, or spring no injury results, as the roots will put out more growth.

Note-Sweet Peas are unusually high this year on account of crop failure, but we have made our prices very low, considering quality.

\section{PRICES ON ALL SWEET PEAS}

Pkt., 5c, Oz. 10c, 1-4 Lb, 35c, Lb. $\$ 1.25$ white.

Dorothy Eckford-Large flowering pure

Emily Henderson-Early, pure white; splendid.

Mont Blanc-Very early, pure white.

White Wonder-Large prolific, pure white.

Prince of Wales-Bright crimson rose.

Prima Donna-Clear rich pink.

Aurora-Light salmon pink, delicate.

King Edward-Fine bright crimson.

America-Dark red, striped lighter.

Salopian-Fine brilliant scarlet.

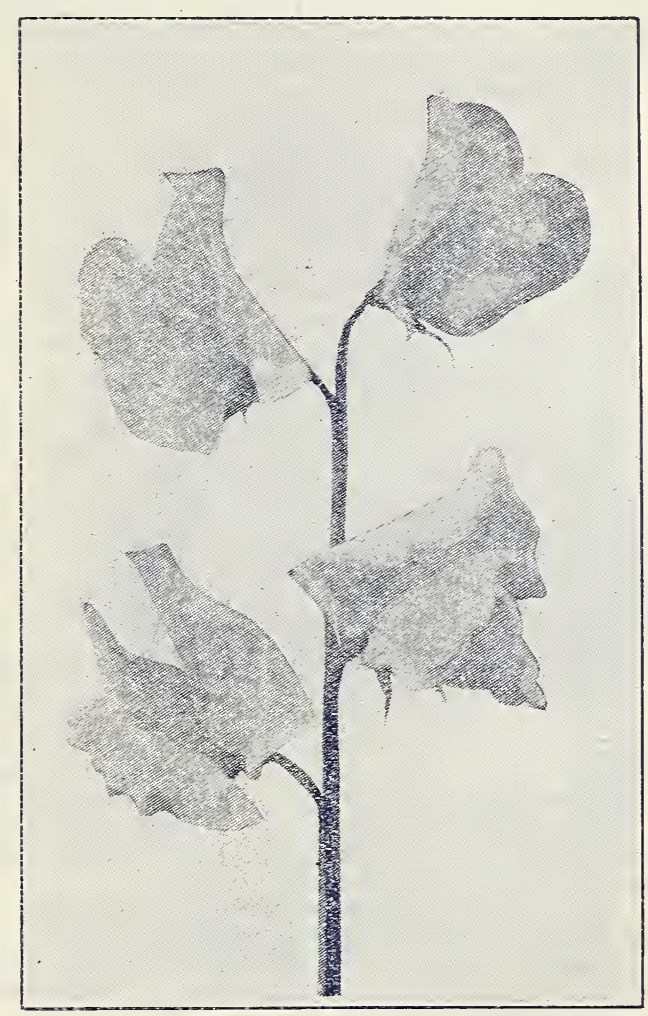

SWEET PEA

Countess Radnor-Handsome lavender.

Dorothy Tennant-Light purple mauve.

Duke Westminister-Handsome clear purple.

Captain of Blues-Finest blue.

Choice Mixed-Mixture named sorts.

Eckfords Hybrids-Every color and shade.

\section{Spencer Variety Sweet Peas}

This is a new type of Sweet Pea lately originated. They are known as Orchid-Flowering Sweet Peas, and are distinguished for their enormous size, usually measuring two inches across. The type produces very long stems; flowers waved, crimped and fluted in beautiful fashion. Most every stem produces three to four flowers.

Choice Mixed-In this mixture will be found a large selection of brilliant colors, made up with such varieties as mature or flower at the same time. Every one who grows Sweet Peas should plant a row of these magnificent types. Pkt., $5 \mathrm{c} ; \mathrm{oz} ., 15 \mathrm{c} ; 1 / 4 \mathrm{lb}$., $60 \mathrm{c} ; 1 \mathrm{~b}$., $\$ 2.00$. 


\section{Flower Seed}

\section{NOTICE}

The varieties of flower seeds here listed are of the finest German and American strains and are certain to prove satisfactory providing they receive proper cultivation. Always bear in mind that flower seeds are not as hardy nor have they the vitality of ordinary vegetable seeds. Therefore, careful attention should be given to planting the seeds and to resetting the young plants. Those seeds that require very early planting may be started in boxes covered with glass. The glass will draw the heat from the sun and also keep out the cold winds. Water moderately. Never let the soil get too wet or the seeds will decay. Always cover flower seeds as lightly as possible and then press the earth firmly on them. A larger per cent will then germinate and grow off much quicker.

For Vines and Climbers, see page 69.

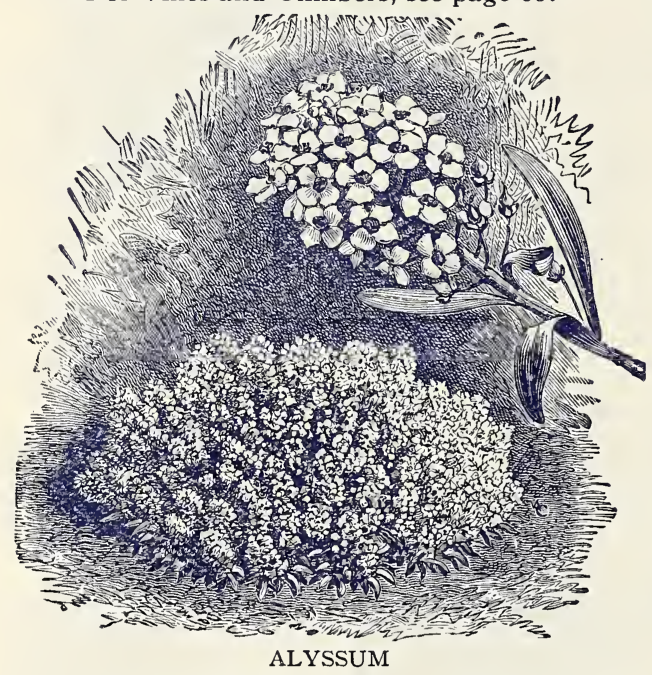

ALYSSUM-An early hardy annual, suitable for indoor or outdoor culture, bloom white, sweetscented and fine for beds or borders.

Sweet (Maritimum) - Grows about eight inches high, profuse bloomer and splendid for bouquets. Pkt., 5c.

Lit tle Gem (Carpet of Snow) - A splendid dwarf sort, growing about six inches high, and forms a perfect bed of beautiful white scented flowers. Fine for baskets or borders. Pkt., 5c.

AGERATUM - A splendid class of hardy freeblooming annuals, bearing its bloom in dense clusters, blooms all summer and fine for bouquets.

Mexicanum-Splendid light blue, growing foot and a half to two feet high. Pkt., 5c.

Dwarf White-Pure white, growth about ten inches. Pkt., 5c.

Dwarf Blue-Growth about six to eight inches high. Pkt., 5c.

AMARANTHUS-A class of plants grown for their magnificent foliage. The leaves and stems are of different shades of red, blended into green and other brilliant colors.

Tricolor-A hardy annual; leaves.red, yellow and green; known as "Joseph's Coat." Pkt., 5c.

Melancholicus Ruber-A hardy annual; foliage a deep coppery red. Pkt., 5c.

ASTERS-The Asters are the handsomest and most profitable annuals grown either by the professional florists or private gardeners. They are very hardy, can be planted early, and a good many sorts last until late in the fall.

Extra Early Hohenzollern-Plants medium size, about eighteen inches, branching in habit, long stems, blooms large, very early. All colors mixed, rose, blue, white, lilac and etc. Pkt., 10c.

Asters Queen of the Market-Very early, free bloomer, branching stems about fifteen inches long, flowers double and fine for cuttings. All colors mixed, white, pink, rose, blue, violet and crimson. Pkt., 10c.

Victoria-Early large type aster, petals thick and full centers; plants eighteen inches high and free flowerings.

Pure White-Pkt., 10c.

Light Blue-Shaded with lavender. Pkt., 10c.

Crimson-Pkt., 10c.

Choice Mixed-Pkt., 10c.

Gregro Giant Pink-A very large attractive soft shell pink, branching in habit, stems long. Pkt., 20c.

COMET ASTERS-A class of half drawf asters, flowers three inches in diameter. Plant branching, but compact and upright. All colors mixed. Pkt., 10c.

Pkt., $10 \mathrm{c}$

Daybreak-A medium early branching sort; blooms light pink, double with curved petals.

ASTERS SEMPLES BRANCHING-A late blooming class of asters, bearing their large double blossoms on long stems. Fine for cut flowers and bouquets. Choice mixed. Pkt., 10c.

BALSAM (Commonly called Touch-Me-Not and Ladies-Slipper)-A hardy annual about 12 to 24 inches high, producing a number of blooms curiously shaped and of many colors, spotted, white, red, purple, etc..

Double Camelia-Flowers white and blotched with various colors. Choice mixed. Pkt., 5c.

Double Pure White-Fine for cut flowers. Pkt., 10c.

Mixed Double Dwarf-Pkt., 5c.

Mixed Double Tall-Pkt. $5 \mathrm{c}$.

CALLIOPSIS-A hardy annual producing flowers of brilliant colors from yellow to rich brown.

The flowers are born on long stems and very desirable for cutting.

Fine Mixed, Pkt., 5c. 


\section{Flower Seed-Continued}

CANDYTUFT (Iberis) - A hardy annual growing twelve to fifteen inches high, bearing beautiful flowers of a wide range of colors. It's a fine bedding plant as well as for cut flowers.

Pure White-Pkt., 5c.

Fancy Mixed, All Colors-Pkt., 5c.

CANNAS-This is one of the finest ornamental plants, producing great spikes of brilliant colored flowers. We offer roots only that you can get results from the first season, and they may be allowed to remain in the ground indefinitely, multiplying and coming up each season.

King Humbert-Giant Scarlet flowering, with bronze foliage. Roots, 10c each; doz., \$1.00.

Florence Vaughan-Tall green foliage, flowers bright red, spotted with darker shades. Roots, 10c each; doz., 75c. doz., $75 \mathrm{c}$.

Burbank--Tall green foliage, flowers rich canary, spotted on inside crimson. Roots, 10c each,

Chas Henderson.- - Height four feet, large crimson flowers. Roots, 10c each; doz., 75c.

Madam Crozy-Height $31 / 2$ feet; flowers red and gold. Roots, 10c each; doz., 75c.

Queen Charlotte-Four feet; flowers rich orange scarlet, with edging of darker shades. Roots, 10c each; doz., 75c.

Milwaukee-Height $31 / 2$ feet; flowers dark maroon. Roots, $10 \mathrm{c}$ each; doz., $75 \mathrm{c}$.

Frau Maria Magel-Three feet; flowers creamy white. Roots, 10c each; doz., 75c.

CANTERBURY BELL - Hardy biennials, producing large bell-shaped flowers of various colors.

Double Mixed-Pkt., $5 \mathrm{c}$.

Single Mixed-Pkt., 5c.

CARNATION MARGUERITE - F l o w e r s large, double, fragrant, all shades of color. Pkt., 5 c.

CASTOR BEAN (Ricinus)-Grown for its beautiful shades of variegated foliage. Pkt., 5c.

CELOSIA (Cockscomb)-Grown for their beautiful sprays of foliage and bloom. Dwarf mixed sorts., pkt., 5c.

CENTAUREA (Cyanus, Batchelors Button, Corn. Flower) - A hardy outdoor plant, producing a profusion of blue, purple, pink and white flowers in summer and autumn. Pkt., mixed, 5c.

COLEUS-A popular plant grown for its splendid foliage of many colors. Fine Mixed Hybrids, Pkt., 25c. Can also supply plants in season. Write us.

COLUMBINE (Aquilegia)-Hardy perennials, flowers orange, red and yellow.

Californica-Flowers single, orange and red. Pkt., 10c.

Mixed Double-Pkt., 5c.

COSMOS-Hardy annuals, producing great sprays of flowers in early fall.

Early Dawn-Early white flowering sort. Pkt., 5c.

Giant Hybrids Mixed-Pkt., 5c.

Early Mixed-Pkt., 5c.

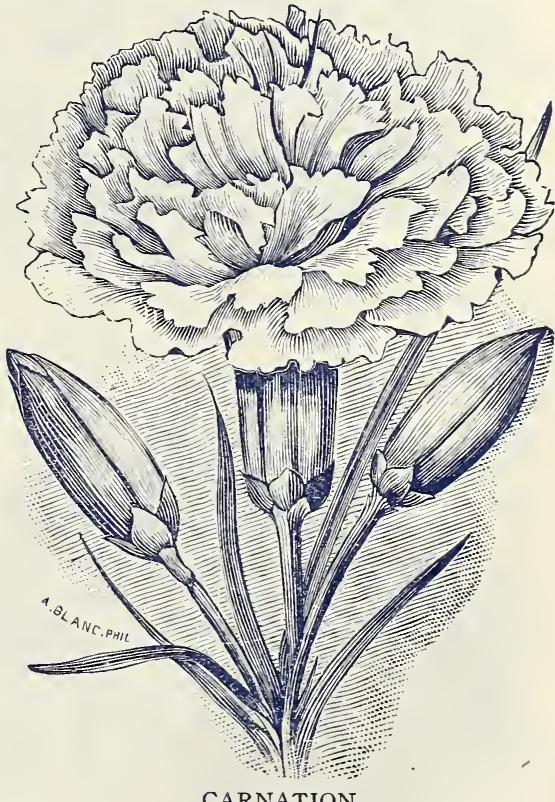

CARNATION

DAHLIA-These can be grown from seed, but it's better to buy roots, which we can supply in clumps from 15 to $25 \mathrm{c}$ per clump.

Price of Seed-Double Mixed, pkt., 15c; Single Mixed, pkt., 10c.

DAISY (Bellis Perennis) - Tender perennials, six to eight inches high; fine for beds or borders flowers white and rose.

Double White-Pkt., 10c.

Double Mixed-Pkt., $5 \mathrm{c}$.

ESCHSCHOLTZIA (California Poppy) - A hardy annual, about one foot high, producing a brilliant effect when in full bloom, color various shades, orange and orange mixed. Pkt., $5 \mathrm{c}$.

FORGET-ME-NOT (Myosotus) - A hardy perennial, producing a profusion of blue flowers in clusters. Pkt., 5 c.

FOUR O'CLOCK (Marvel of Peru)-A hardy branching annual, two feet high; flowers open evening; colors yellow, striped and blotched mixed. Pkt., 5c.

FOX GLOVE (Digitalis) - A hardy biennial, three to five feet high, producing long spikes of flowers; colors white, lavender, and rose. Fine mixed. Pkt., 5c. 


\section{Flower Seed-Continued}

GAILLARDIA-Hardy annual, 12 to 18 inches high; flowers of brilliant colors.

Picta Lorenziana-Flowers double, colors sulphur, orange, claret and etc.. Mixed. Pkt., 5c. GLOBE AMARANTH-An annual everlasting flower; colors striped, purple and white. Mixed

Pkt., 5c.

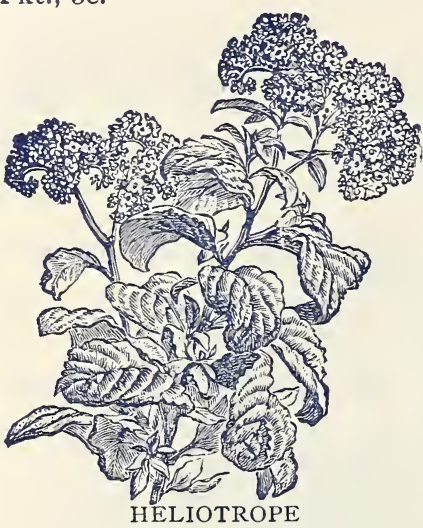

blue. Hybrids mixed. Pkt., 5c.

HELIOTROPE-A hardy perennial, 18 to 24 inches high; blooms very fragrant, mostly purple or blue. Choice mixed. Pkt., 10c.

HYBISCUS-A hardy annual, two feet high, color light yellow, purple center. Pkt., 5c.

HOLLYHOCK-A hardy perennial, growing four or five feet high, producing brilliant sprays of flowers of many colors.

Double Rose-Pkt., 10c.

Double Pink-Pkt., 10c.

Double Yellow-Pkt., 10c.

Double White-Pkt., 10c.

Double Mixed-Pkt., 5c.

LANTANA - A rapid-growing perennial, producing single flowers in clusters, many colors, and forming green berries that turn to deep

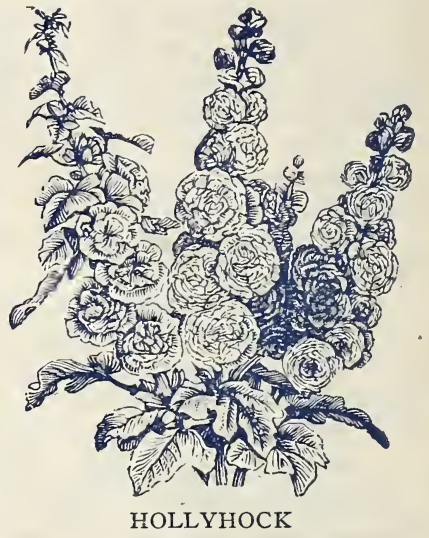

HOLLYHOCK

LARKSPUR-Hardy annuals, producing brilliant sprays of many colors.

Double Dwarf Rocket Mixed-Pkt., 5c.

LOBELIA-Hardy annual, 6 to 8 inches high.

Emperor William-Fine Blue. Pkt., 5c. late in fall.

MARIGOLD-A class of hardy annuals; planted ${ }_{\xi}^{5}$ in early spring, afford splendid flowers until

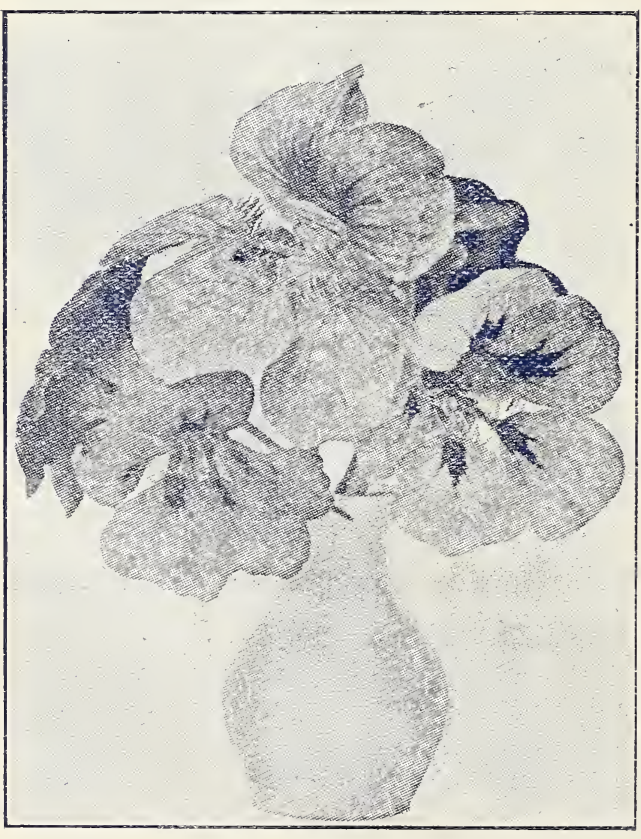

NASTURTIUMS

Meteor-Double light yellow, shaded with orange. Pkt., 5c.

Prince of Orange-Double golden yellow, with darker shades. Pkt., 5c.

African Double Mixed-Tall variety; large flowering; mixed. Pkt., 5c.

Legion of Honor-A single dwarf, rich yellow and dark red. Pkt., 5c.

MIGNONETTE-A hardy annual, producing great spikes of sweet scented flowers.

Sweet Mignonette-Pkt., 5c.

Machet-Dwarf vigorous sort; flowers red. Pkt., 5c.

Golden Queen-Sweet-scented, large golden yellow. Pkt. , 5:

MIMULUS-Hardy annuals, fine for pots or hanging baskets.

Moschatus (Musk Plant)-Trailing, green foliage, small fragrant yellow flowers. Pkt., 5c.

Punctatus (Monkey Flower) - Large yellow flowers, spotted with maroon. Pkt., 5c.

MOURNING BRIDE - Hardy annual, twelve to eighteen inches high; beautiful flowers; long stems, and many colors.

Double Mixed-Purple, scarlet, deep red and white. Pkt., 5c.

NASTURTIUMS-The most popular and more easily grown than most any of the hardy annuals. We supply them in the trailing or running and dwarf sorts. They are fine for bedding or window boxes. Colors of every shade and hue.

Dwarf Mixed-Pkt,, $5 \mathrm{c}$.

Bronze-Large flowers, bronze and orange. Pkt., 5c.

Crimson-Very large, dark crimson. Pkt., 5c.

Empress of India-Dark foliage; scarlet flowers. Pkt., 5c.

Yellow-Pure golden yellow. Pkt., 5c.

Tall Mixed-Trailing sorts, mixed colors. Pkt., 5c. 


\section{Flower Seed-Continued}

Giant of Battles-Tall sulphur color, red blotches. Pkt., 5c.

King of the Blacks-Tall; flowers crimson, dark markings. Pkt., 5c.

PANSIES-Pansies are universally grown for their beauty and colors. The finer varieties ought to be planted in later summer and early fall, to be transplanted in January, February; still they can be planted in early spring, when they flower in later summer. We can supply plants of these. Write us.

Choice Mixed-Pkt., $5 \mathrm{c}$.

Giant Mixed-Pkt., 10c.

Meteor-Fancy large red. Pkt., 10c.

Pure Yellow-Deep lemon yellow. Pkt., 10c.

Large White-Handsome, pure white. Pkt., 10c.

Striped and Variegated - Many colors. Mixed. Pkt., 10c.

PHLOX-Hardy annuals, 12 to 18 inches high, producing splendid sprays of many colored flowers; fine for cuttings or bouquets.

Black Warrio,r-Fine deep maroon. Pkt. 10c.

Isabellina-Fine creamy yellow. Pkt., 10c.

Lilac-Fine lilac, white center. Pkt., 10c.

Scarlet-Fine red, with dark center. Pkt., 10c.

Splendens-Pure red with white eye. Pkt., 10c.

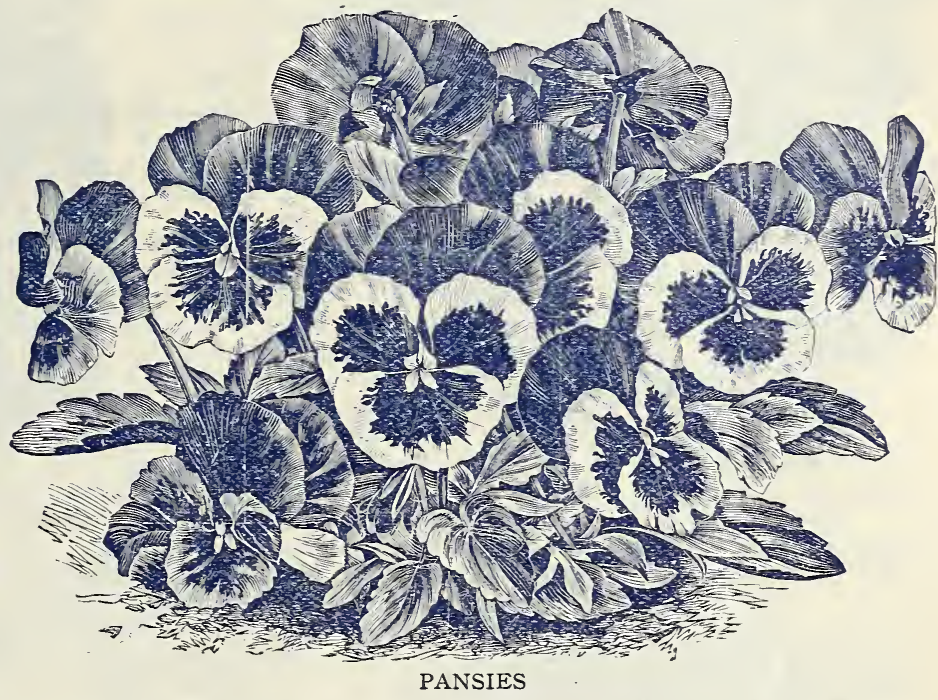

Extra Choicest Mixed-All best sorts. Mixed. Pkt., 5c.

PINKS (Dianthus), Pinks, Carnations, Sweet William and Japanese Pinks belong to the same family and afford the most popular class of flowers grown. They embrace nearly every color, hardy, and may be had all the year round.

Double China Mixed-Colors crimson, white, purple, red, and blotched. Pkt., 5c.

Double Diadem Mixed (Heddiwigs) -All colors, purple, and red. Pkt., 5c.

Royal Pinks (Heddiwigs) - Single, all colors, red, pink, and white. Pkt., 10c.

Double Japan-All shades of dark colors. Pkt., 5c.

PETUNIAS-This is one of the finest flowering plants grown in the South. They are shy seeders, and the seed themselves are very expensive, but we have made our prices very cheap, considering

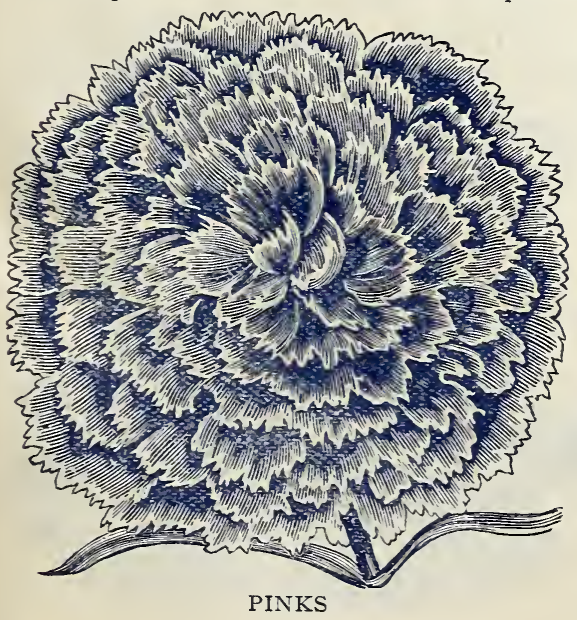
quality.

Striped and Blotched-Pkt., 5c.

Fine Mixed- Pkt., 5c.

Double MixedPkt., 20c.

Extra Double Fringed MixedPkt., 25c.

POPPY - This well known hardy annual and perennial needs no introduction. They are very successful in the South, so no one can go wrong in their cultivation.

Shirley - A hardy annual of many colors. Mixed. Pkt., $5 \mathrm{c}$.

Tulip FloweredBright scarlet. Pkt., 5c. Cardina l-Large double Cardinal Red.

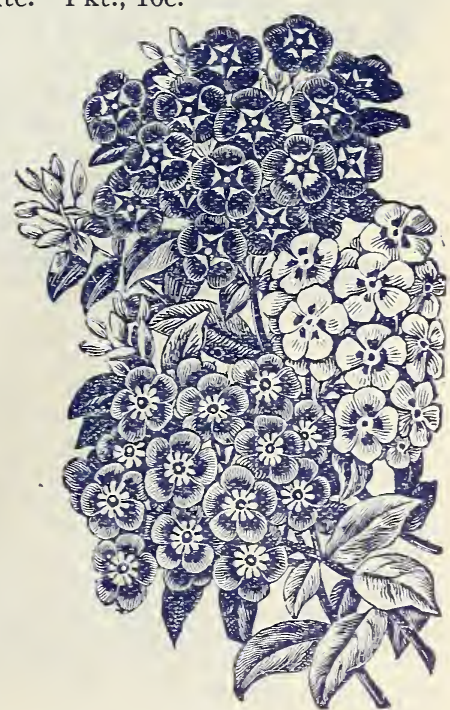

PHLOX 


\section{THE PLAIN TRUTH ABOUT SEED MEVAY SEED AND FLORAL COMPANY

\section{Flower Seed-Continued}

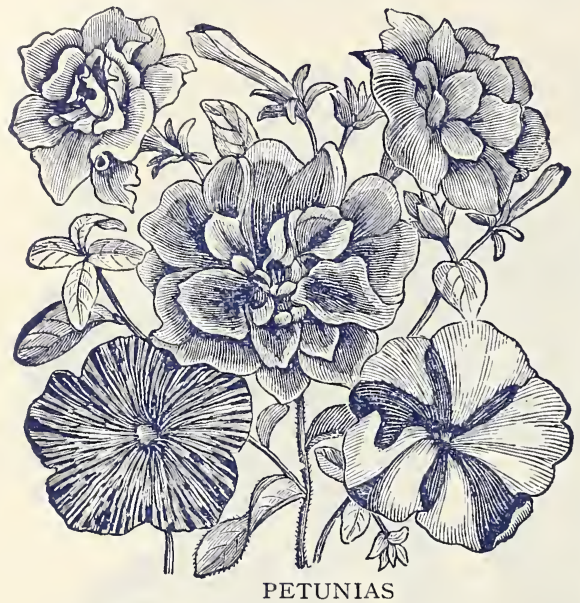

Double Mixed-

All colors. Pkt., 5c.

Double White

一Pkt., 5c.

Double Mixed

-Pkt., 5c.

(Moss Rose) - A tender annual, about ten inches high of mixed colors of many hues.

Double MixedPkt., 5c.

Sing 1 e Fine Mixed-Pkt., $5 c$.

P R I M R O S E - EV E N I N G-An immense blooming flowering plant; bloom yellow and white. Pkt., 5c.

PYRETHRUM-A very hardy perennial, producing

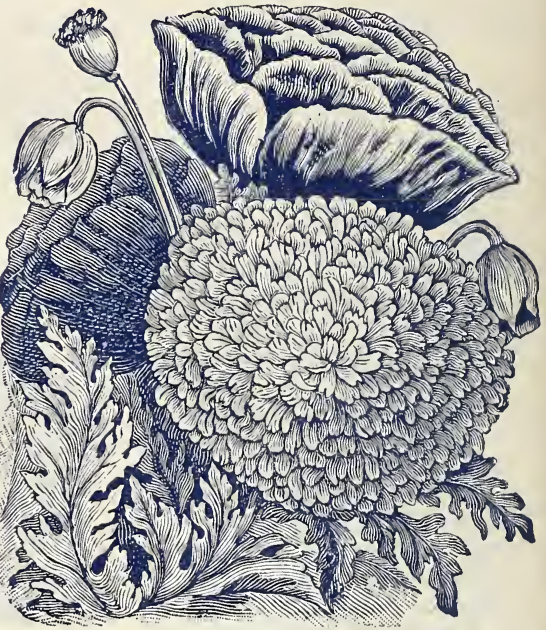

POPPY flowers of every hue. Pkt., 5c.

SALPIGLOSSIS-A hardy annual, producing flowers of purple shades, scarlet, crimson, yellow, etc., and very desirable for bouquets or cut flowers. Pkt., 5c.

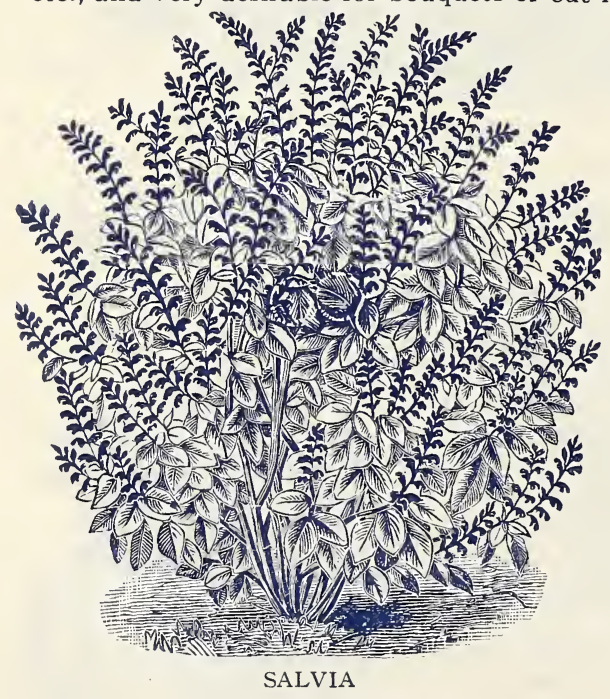

Defiance-Deep scarlet. Pkt., 5c.

Pure White-Large flowers. Pkt., 5c.

All Shades Blue. Pkt., 5c.

Mammoth White-Pkt., 10c.

VINGIA (Periwinkle) - A hardy perennial, blooming from seed the first year; height fifteen inches; many colors.

White-Pkt., $5 \mathrm{c}$.

Rosa Alba-Rose with crimson eye. Pkt., 5c.

Mixed All Colors-Pkt., 5c.

WALLFLOWER - A Southern perennial, blooming all season; flowers produced on great spikes of many colors.

Mixed Double-Pkt., 10c. colors.
SALVIA (Flowering Sage)-We can supply seeds or plants, but they are easily grown from seed, if planted in early spring. Flowers brilliant red, and born on long spikes. Pkt., 10c.

SENSITIVE PLANT (Mimosa Predica)-A tender annual, one and a half feet high; flowers pink; a plant peculiar to touch. Pkt., 5c.

SNAP DRAGON (Antirrhinum)-A splendid annual in the South, beautiful foliage; flowers beautiful and of many shades. Mixed. Pkt., 5c.

Stocks Double German Ten Weeks-An annual in the South, producing an abundance of flowers double of shades, of white, red, purple, lavender and maroon. Pkt., 5c.

SUNFLOWER (Helianthus)-One of the best known annuals, hardy, and of many colors. Mixed. Pkt., 5c.

Stella-Pkt., 5c.

SWEET WILLIAM (Dianthus Barbatus)-An oldfashioned pink, much prized for its brilliant colors and bouquet effect.

Mixed Single-Pkt., $5 \mathrm{c}$.

Double Mixed-Pkt., $5 \mathrm{c}$.

VERBENA - A hardy annual in the South and grown for its magnificent mass of blooms of many

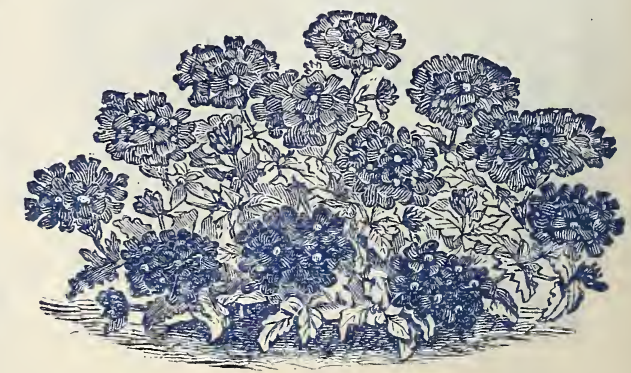

VERBENA 


\section{Flower Seed-Continued}

ZINNIA-Zinnias are hardy annuals in the South, about 18 to 24 inches high, producing large double flowers of many colors and lasting for some time.

Dark Crimson-Pkt., 5c.

Deep Red-Pkt., 5c.

Magenta-Pkt., $5 \mathrm{c}$.

Orange-Pkt., 5c.

Black Purple-Pkt., 5c.

Choice Mixed-Pkt., 5c.

\section{Climbers, or Shade Vines}

MORNING GLORY -A rapid growing annual, 30 to 40 feet high, producing an abundance of brilliant colored flowers.
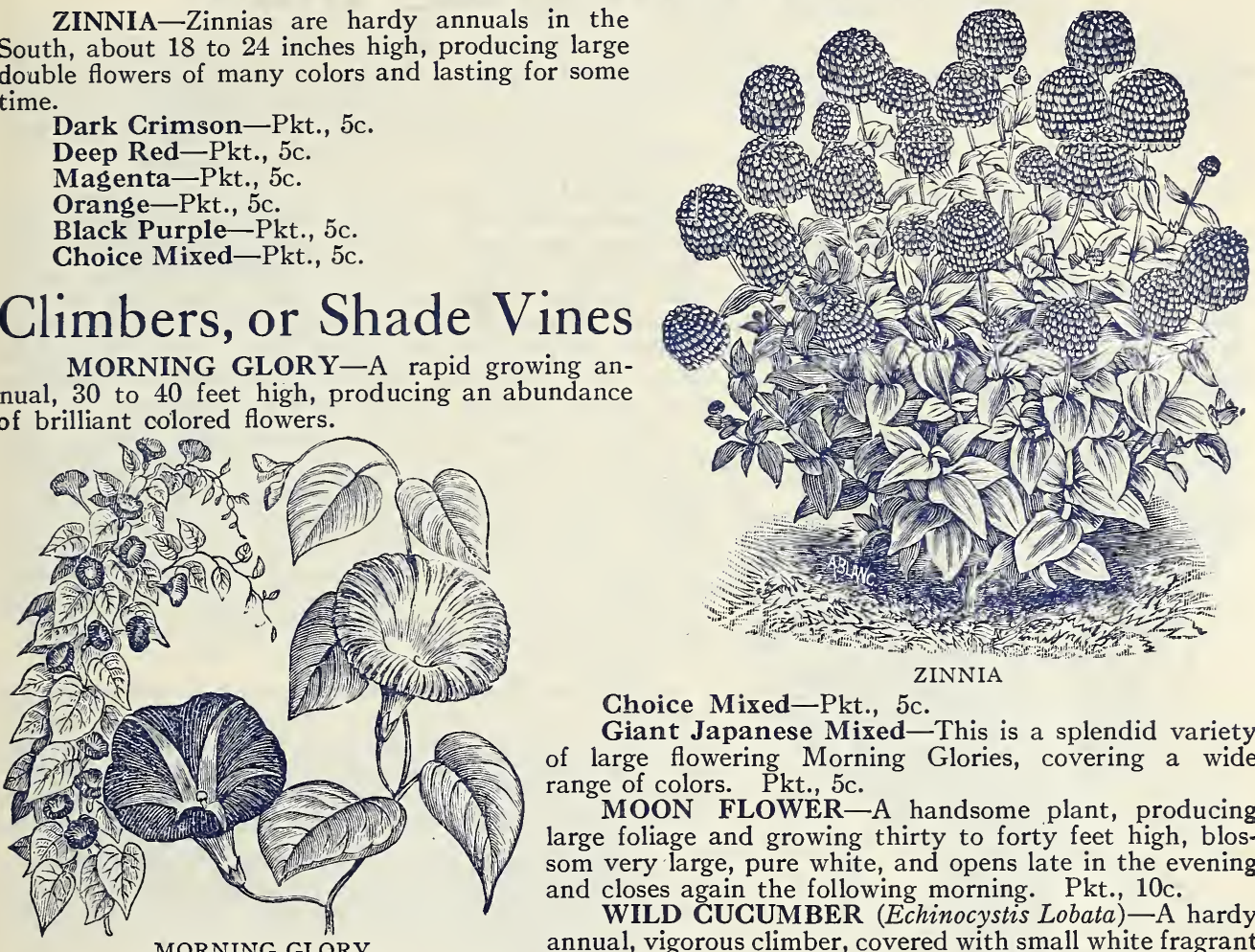

Choice Mixed-Pkt., 5c.

Giant Japanese Mixed-This is a splendid variety of large flowering Morning Glories, covering a wide range of colors. Pkt., 5c.

MOON FLOWER-A handsome plant, producing large foliage and growing thirty to forty feet high, blossom very large, pure white, and opens late in the evening and closes again the following morning. Pkt., 10c.

WILD CUCUMBER (Echinocystis Lobata) -A hardy annual, vigorous climber, covered with small white fragrant flowers, followed by prickly seed pods. Pkt., $5 \mathrm{c}$.

BALLOON VINE (Love in a Puff)-An annual, 6 to 8 feet high, graceful foliage, flowers small white, seed born in a peculiar pod. Pkt., $5 \mathrm{c}$.

CANARY BIRD FLOWER-A tender annual, about twenty feet, small curiously shaped canarycolored flowers, attractive foliage. Pkt., 5c.

COBAEA SCANDENS-A perennial, about thirty feet high, handsome foliage, flowers bellshaped, and when grown a deep violet blue. Pkt., 5c.

CYPRESS VINE-A popular annual climber, about fifteen feet high. Foliage a dark green, feathery-like, and many bright star-shaped flowers, white and scarlet.

Scarlet-Pkt., 5c.

Mixed-Pkt., 5c.

JAPANESE HOPS-Hardy annual, fifteen to twenty feet; foliage large and rough, with small flowers. Pkt., 5c.

JACK BEAN (Hyacinth Bean) - A tender annual, ten to fifteen feet high, producing clusters of bloom, purple and white.

Mixed-Pkt., 5c.

White-Pkt., 5c.

Purple-Pkt., 5c.

MAURANDIA -A tender perennial, 6 to 10 feet high; ivy-shaped leaves, blossom trumpet-shaped flowers, blue, white, and rose. Mixed. Pkt., 5c.

BALSAM PEAR-An annual clumber, ten to fifteen feet, bears fruit pear-shaped, bright red, when ripe bursts open, showing red seed. Pkt., $5 \mathrm{c}$.

BALSAM APPLE-Like balsam apple, fruit smaller, round, green striped, becoming red when grown. Pkt., 5c. GOURDS-These are widely grown for their ornament as well as for their usefulness.

Mixed Ornamental-Pkt., 5c.

Dish Cloth-Pkt., 5 c.

Nest Egg-Pkt., 5c.

Dipper-Pkt., $5 \mathrm{c}$.

Hercules Club-Pkt., 5c.

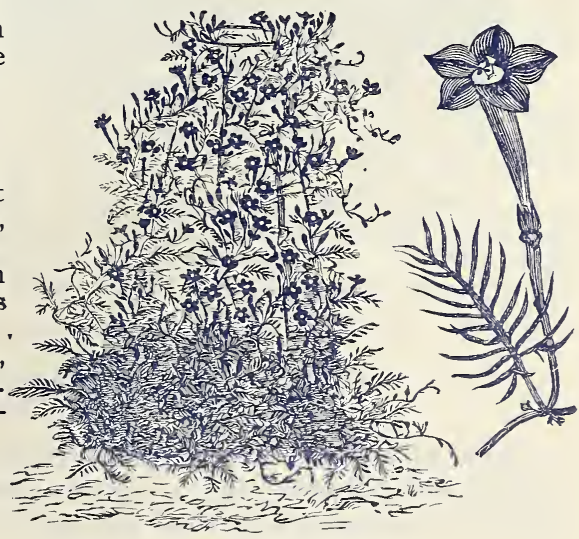

CYPRESS VINE 


\section{Summer Flowering Bulbs}

GLADIOLUS - This is the most brilliant and showy of all the summer flowering bulbs. There are hundreds of varieties of Gladiolus. Their immense spikes of gorgeous blooms comprising the most select colors and shades and many most delicate tints. They will grow in any good garden soil.

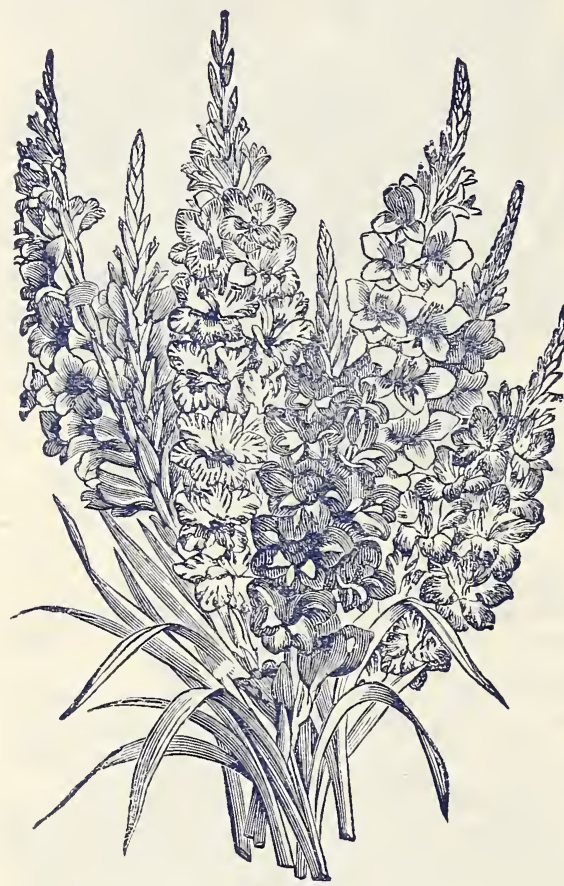

GLADIOLUS

We have an extra choice mixture large bulbs with all sorts of colors. Doz., by mail, postpaid, 30c.

DAHLIAS-There is no flower more showy and satisfactory than the Dahlia, and so easily grown that every one may have a grand display at but little expense. They make a large bush, and commence to bloom early, and continue until killed by frost. Very fine for cut flowers. We carry the following colors: Double White, Yellow, Purple, Pink and Dark Red. Price-Best fieldgrown roots $15 \mathrm{c}$ each, three for $40 \mathrm{c}$; $\$ 1.25$ per doz., assorted. If by mail, add $10 \mathrm{c}$ each for postage.

Jack Rose-A new decorative double Dahlia, the Floral Sensation of the Season, and the greatest Dahlia acquisition. The very large flowers measuring 6 to 7 inches across and 4 inches deep, with full high center. Color-That brilliantly rich velvety crimson that cannot be found elsewhere. Plants are strong and vigorous, with long erect flower stalks, producing 25 to 50 flowers on 20 to 24 -inch stems. Price of strong field-grown roots50 c each; 3 for $\$ 1.35$

Maid of Kent-We are free to call this the most beautiful of all decorative Dahlias. It is the richest crimson velvet color imaginable, and about half of the petals are tipped with a large spot of white, thus adding greatly to its brilliancy. Frequently the flowers are solid scarlet, most of them variegated. Each, 20c; doz., $\$ 2.00$.

Fern Leaf Beauty-This grand new Dahlia has fernlike foliage and flowers of creamy white, with a distinct marking of bright crimson on each petal. Price-20c each; 3 for 50 c.

Queen Victoria-This has long been considered the finest deep yellow variety which we have. Plant a robust grower and it will appear almost a solid mass of golden yellow. Each 15c; 3 for 40 c.

Rose Pink Century-Every lover of single Dahlias should grow this variety. The plants are perfect giants, growing from 5 to 7 feet high, bearing immense beautiful flowers on long straight stems. The flowers of this variety when cut are of great substance. last longer than any other single Dahlia. Price of strong field-grown roots, 50c each; 3 for $\$ 1.35$.

Caladium Esculentum (Elephant's Ear) - These make very ornamental plants for lawns. They grow from four to five feet high, producing enormous, beautifully veined leaves, of different shades of green, often from three to four feet long and two to three feet wide, of easy culture. Plant in deep rich soil and water freely. Price-Mammoth bulbs, 15c each; 2 for 25c; large bulbs, $10 \mathrm{c}$ each, 3 for $25 \mathrm{c}$. If by mail, add $5 \mathrm{c}$ each for postage.

Cycas Revoluta (Also known as Sago Palm)-Used for lawn and house decoration; has heavy, deep green, glossy fronds of leaves, are not affected by dust or gas. We carry fine roots or bulbs. Price: Bulbs, 10c per lb. The bulbs will run from $1 / 2$ to $6 \mathrm{lbs}$. each. If to be sent by mail, add to price $10 \mathrm{c}$ per lb. extra for postage.

TUBEROSES. Excelsior Pear1-Our stock of Tuberoses is direct from one of the largest and 'most reliable growers, and can be depended upon to produce perfect blooms in the same season planted. The wax-like white, sweet-scented flowers are unsurpassed for button-hole bouquets. Price-25c per dozen; 100 for $\$ 1.50$. If by mail, add 10 cents. per dozen for postage.

\section{Fall Bulb Catalogue}

We issue an exclusive Bulb Catalogue in September, covering all bulbs to be planted in the Fall and Winter. Don't forget to write for a copy in season. We handle many bulbs we don't list, so let us know what you want, we can supply it. 


\section{Poultry Supplies}

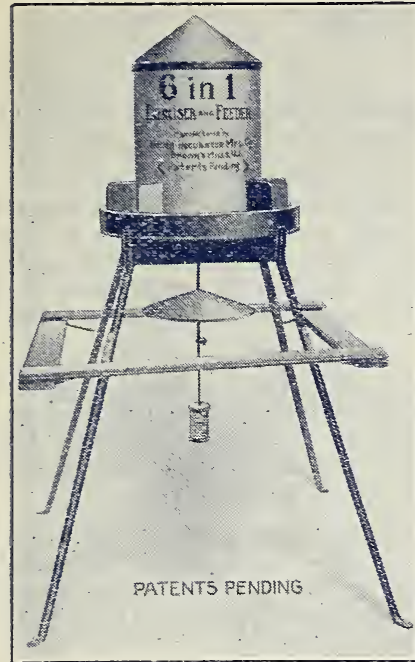

SIX-IN-ONE EXERCISER FEEDER

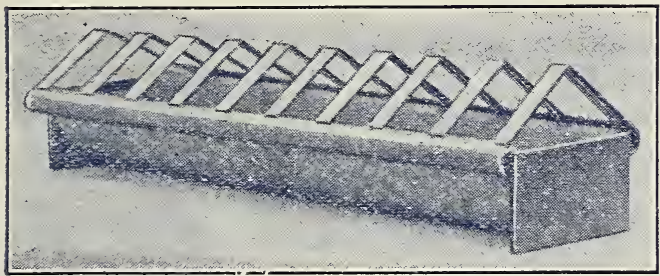

CHICK FEED TROUGH

Six-In-One Exerciser Feeder-Is a large hopper supported on four strong iron legs and devised to hold all the food necessary for poultry. The center hopper holds the mixed grain food and is so constructed that a little agitator, which contains whole corn, as bait, can be worked by the fowls so that it will scatter broadcast a small amount each time, of the dry grain mixture. It gives the hens the necessary exercise hunting for the grains, so that it is impossible to overfeed. Surrounding this center hopper are six compartments made to contain dry mash, beef scraps, grit, charcoal, oyster shells, etc. All are easily accessible for the fowls and the machine is so constructed that none of the food can be wasted. The cover of the hopper is conicalshaped, so that the fowls cannot roost on it. This Exerciser Feeder has every advantage that can be found in an exerciser of other makes. Eliminates all other feeding devices. Price: 40 qt., $\$ 5.00 ; 20$ qt., $\$ 4.00$.

Two-Piece Drink FountsBlack iron, galvanized after fount has been completed. This assures a smoother, better looking fountain, keeps the edge at top from rusting.

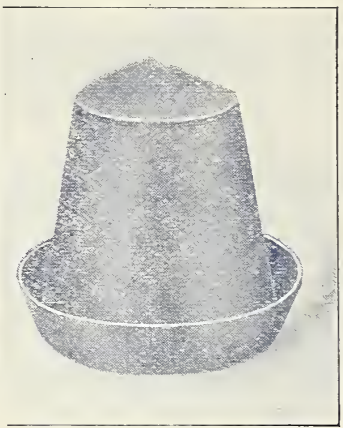

2-PIECE DRINK FOUNT Small, 20c Medium 25c; Large 40c.

Chick Feed Troughs-The only rounded chick feed troughs on the market. No trouble to clean them. The grate slides easily on and off - a feature not found in any other chick troughs. Another feature is that the chicks cannot roost on it. 10-inch size, 30c 20-inch, 50c

Grit and Shell Boxes-Are made of heavy galvanized material, automatic feeding; has three compartments. Price, 50c each.

Dry Mash and Mixed Grain Hopper - Made of heavy galvanized iron. Made with such a slant that it can't clog. Price, $75 \mathrm{c}$ each.

Moe's Sanitary Poultry Drinking Fountain-1 gallon capacity, $\$ 1.25 ; 2$ gallon capacity, $\$ 1.75$.

Moe's Rat Destroyer-Insures the safety of your fowls, while poisoning the rats and mice in your poultry yard. Price, $\$ 1.00$ each.

Moe's Self Locking Leg Band-1 doz., 15乞, anys ize.

Moies Round Feed Saving Hopper-Made round. so that it will accommodate more birds at one time than any other hopper on the market. One-half bushel size $\$ 1.00$; one bushel size, $\$ 1.50$.

Moe's Sanitary Brooder Fountain-Little chicks can't get wet. Sits in corner of brooder. Takes up little room. Can't be upset. One quart size, 25 cents.

Moe's Triple Compartment Grit and Shell BoxCan also be used as Feed Hopper for little chicks, price 50c.

Write for Descriptive Catalogue of Moe's Supplies.

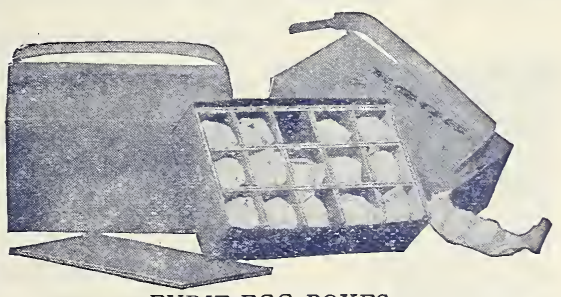

Eyrie Egg Boxes-Price: 1 setting, dozen, $\$ 1.50$

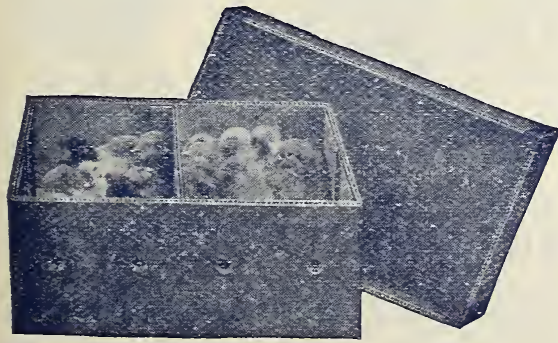
2 settings, dozen, $\$ 2.25$.

Bone Mills-For grinding green bone and etc. We are large handlers of the Mann's Green Bone Cutter. Price: $\$ 11.50$.

Chick Boxes-A splendid device for shipping young chicks. Sizes: 25 chicks, each, $25 \mathrm{c} ; 50$ chicks, each, $35 \mathrm{c}$ 10 ? chicks, each, 50c

Eyrie Shipping Coop-A spendid cheap device for shipping grown chickens. One chicken size, 50c; two chicken size, 75 c.

O. K. Poutry Litter-We are agents for this famous compound. Keeps away lice, mites from your chicken house, and is valuable as a disinfectant. Pricc: $\$ 3.75$. Ball weighs 175 pounds. 


\section{Conkey's Goods}

We are agents for this well known brand of goods, carry their goods in stock and can supply you with valuable literature covering the line. Write us to mail you Conkey's Poultry Book-retail price, fifty cents but sent by us free.

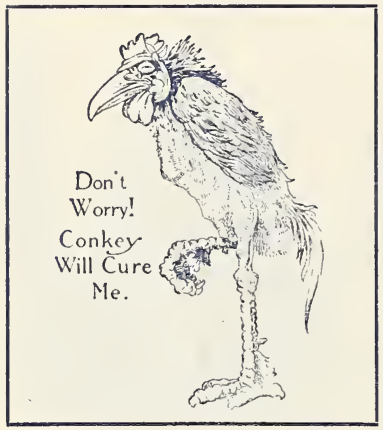

Conkey's Laying Tonic-We have found this the most valuable compound of vegetable ingredients that we have ever seen to keep chickens in good condition all the year round and induce them to lay. It should be understood that Conkey's Laying Tonic is not a food, but strictly a medicine to keep fowls in good laying condition. Price: $11 / 2$ lb. pkg., 25c; $31 / 2$ lb. pkg, 50c.

Conkey's Lice Liquid-This is a concentrated liquid that must be diluted twenty-five to fifty times its bulk in water and used in a spray or sprinkled on to kill and prevent all sorts of vermin. Used in coops, chicken houses or on roost poles. It gives the greatest satisfaction. Price: 1 qt., $35 \mathrm{c} ; 1 / 2$ gal., $60 \mathrm{c} ; 1$ gal., $\$ 1.00$.

Nox-I-Cide-This is a soluble disinfectant and one of the best friends the lpoultryman can have around. One gallon will make a hundred gallons of useful disinfectant to kill germs and for general purposes to destroy vermin. Price: 1 qt., $50 \mathrm{c} ; 1 / 2$ gal., $75 \mathrm{c} ; 1$ gal., $\$ 1.25$

Sulphur Candles-A valuable remedy for fumigation purposes. Price: Each, 10c.

Conkey's Distemper Remedy-A splendid rem-

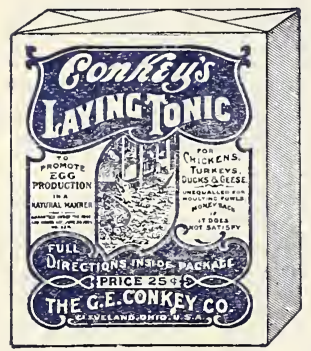
edy for distemper in dogs. Price: $50 \mathrm{c}$.

Conkey's Worm Drops-A perfect remedy for worms in pet stock. Price: 50c.

Conkey's Horse Tonic-A valuable remedy for run-down stock. Price: $\$ 2.00$.

Conkey's Stock Tonic-A valuable remedy in building up an animal, aiding digestion and causing them to take their feed. Price: 25c, 50c, $\$ 1.00$.

Conkey's Salt Em-A new medicated salt desirable to feed to all classes of live stock to keep them in good condition. Price: 10 lbs., 75c; 20 lbs., $\$ 1.25$.

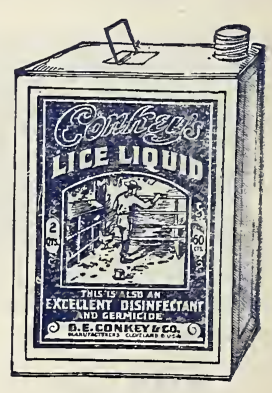

Conkey's Lice Powder-A valuable remedy for keeping lice off poultry and other pet stock. Price: 10c, 25c, 50c, $\$ 1.00$.

Conkey's Head Lice Ointment-Every one who has poultry

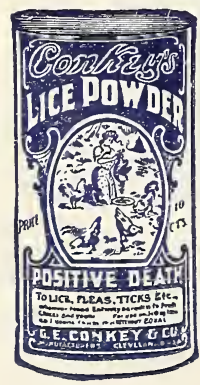
should have this remedy on hand because it never fails to destroy lice. Price: 10c.

Conkey's Fly Knocker-A valuable remedy used in a spray to keep flies off stock, not offensive. Price: $1 / 2$ gal., 60c.

Conkey's Worm Remedy-A splendid remedy for worms in in all classes of live stock. Price: 50c.

Conkey's White Diarrhoea Remedy-This remedy is a positive cure for diarrhoea in chickens. We positively guarantee it. Pkg., 25c, 50c.

Conkey's Hoof Remedy-This will keep the horse's feet in condition and enable him to repay you. Price: 50c, $75 \mathrm{c}$.

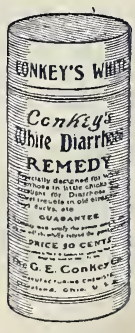

\section{Sterlingworth Plant 'Tablets}

A new scientific, odorless invigorator for houseplants and vegetables. They build up the soil, kill all insects, and insure vigorous growth of both leaf and flower. Three sizes: small size, 10 cents; medium size, 25 cents; large size, 50 cents. 


\section{Poultry Feed}

Sucrene Hen or Scratch Feed-This is our own preparation for grown and half grown chickens. Mixture is made out of the best and sweetest grain, and we know it is pure and does not contain a lot of old junk wheat screenings and other damaged grain. Some people imagine that anything is good enough for chickens, when, as a matter of fact, thousands of valuable birds are killed every day through feeding damaged grain. Scratch feed contains nothing but the following: Choice red wheat, cracked, corn (from the very best milling corn), sunflower seed, kaffir corn, white clipped oats, hemp, red kaffir corn and linseed cake and nothing else, such as grit, oyster shells and other stuff to cheapen it. Write for samples. Prices: Per lb., 3c; per $100-1 b$. bag. $\$ 2.50$. Special price in ton lots.

Sucrene Little Chick Feed-This is also our own formula for small chicks. It is composed of almost the same grains as our Scratch Feed, only it is ground much finer, and contains a small per cent of flax seed, rice and German millet. It has all the fine waste screened out of it, and is all feed: contains no grit, oyster shells or other stuff to cheapen it. Price: Lb., 3c; per 100-lb. bag, $\$ 2.75$. Special price in ton lots.

Aunt Patsy Mash Feed-The greatest mash feed on the market. It is high in protein, and is a great eggproducer and good for building up run-down chickens. It is also a splendid duck mash, being used extensively by the duck raisers of the South. Price: Lb., 3c; per 100-1b. bag, $\$ 2.75$.

Duck Mash-A mash feed specially prepared for us to promote rapid growth. Also a splendid egg producer. Price: L.b., 3c; per 100-lb. bag, $\$ 2.75$.

Grains and Etc.-There is nothing more important for a success with chickens than suitable feed and practical remedies for the many diseases of chickens. We are large dealers in grain and seed of all kinds. No one is in better position than we to make the right prices when it comes to chicken feed.
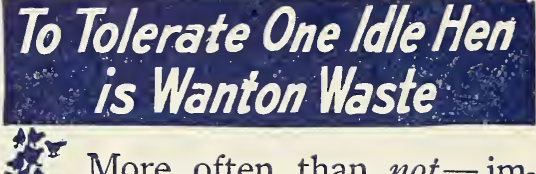

More often than not-improper feeding is to blame for winter losses in egg profits, and it is only through the consistent feeding of Darling's Meat Scraps to your fowls that this condition is thoroughly overcome.

\section{Darling's Meat Scraps $55 \%$ Protein Guaranteed} Produces Minter Eggs

It is the one logical poultry food of high protein content and can be fully depended upon to meet your every requirement. Fine ground, pure, sweet, "fr ee from taint"-Darling's Meat Scraps are better for your fowls-yet cost no more than brands of lower protein content.

Come-get a bas of this high protein meat feed-feed it consistently to your fowls and see for yourself how substantially your egg yourself how substantially
profits will be increased.

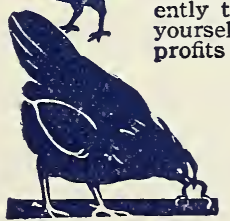

Price, 1b., 4c.

Per 100 lbs., $\$ 3.75$
Red Wheat, per 100 lbs

Kaffir Corn, per 100 lbs.

Millet, per $100 \mathrm{lbs}$

Cracked Corn, per 100 lbs.

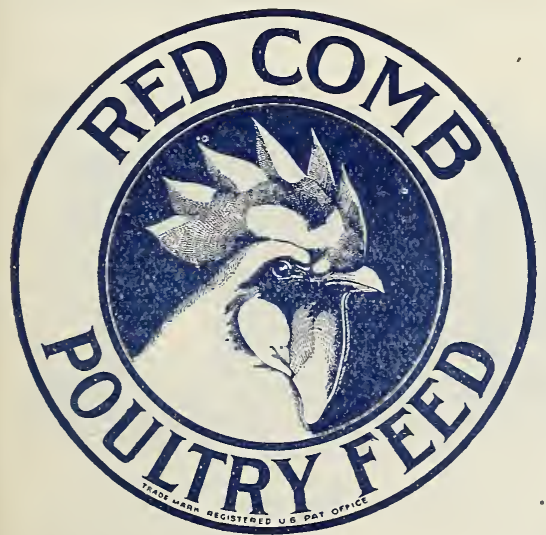

$\$ 3.00$ Hemp Seed, per $1 \mathrm{~b}$ $\$ .10$

2.50 Sunflower Seed, per lb. $\quad .10$

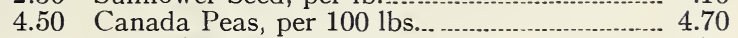

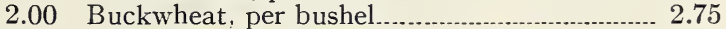

Lime Grit, medium, coarse and fine, $100 \mathrm{lbs..............} \quad .95$

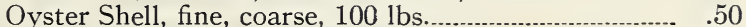

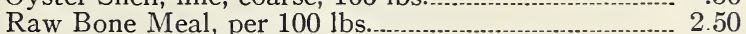

Charcoal, coarse and fine; per $1 \mathrm{~b} . .5 \mathrm{c} ; 50 \mathrm{lbs}, \ldots . . . . . . . . . . .1 .40$

Crushed Bone for Poultry, per lb., $5 \mathrm{c} ; 10 \mathrm{lbs} ., \ldots . . . . . . . . . . . \quad .50$

Red Comb Pigeon Feed-Our own formula; contains principally Canada peas, red wheat, kaffir corn, cracked corn, millet seed and hemp. It is a nice clean feed, well balanced; and will give the most critical the best of satisfaction. Price: Per lb., $31 / 2^{\circ}$ per 100 lbs., $\$ 3.00$.

Red Comb Poultry Feed-A well balanced ration for grown chickens, composed of the best grains, seeds and charcoal. A clean feed well balanced, containing no grit or shell. Will run uniform throughout, the year. Price: Per 100 lbs., $\$ 2.50$.

Red Comb Chick Feed-A splendid feed for young chicks. Only the best of material used, never gets sour or musty. Price: Per $100 \mathrm{lb}$. bag, $\$ 2.75$

Alfalfa Clover-For green stuff during winter, cut clover (Alfalfa) is invaluable to feed in with the mash. It is high in protein, a great egg producer, and aids in keeping all fowls in fine, healthy condition. Price: Lb., $2 \frac{1}{2}$ c; per 100 lbs., $\$ 2.25$.

Spratt's Chick Meal-We have this in three sizes. Fine, size No. 12; Medium, No. 5, and Coarse, No. 3. The very best feed obtainable for forcing. Consisting of dried milk, meat and meal. Price: Per lb., 10c; 3 lbs., 25c. 


\section{International Sanitary Hovers}

\section{GAN BE USED ANYWHERE}

\section{It is not possible in} the space afforded to fully describe the merits of the Sanitary

Hover. So we request

those interested to

write us for special

descriptive matter.

They have stood every climatic test from Panama to Quebec. Practical poultrymen, state experiment stations and poultry judges endorse them. You can raise chicks anywhere with International Sanitary Hovers. No specially constructed houses are necessary. There is no betterpl ace than in your regular hen house.

Sanitary Hovers are as practical for the small back-yard poultry raiser as for large poultry farms. They are warmest at the curtain-usable anywhere-ready for business wherever placed. No crowding or smothering of chicks-no kneeling in mud to get at the lamp-no cutting of holes or building of platforms. You want the best brooding device-you will get it in the Sanitary Hovers. Price, $\$ 8.50$ each.

Rat Proof Cages-At brooding time rats become a serious problem to the poultryman. If they can get at the chicks, the loss from their activities is likely to be considerable.

The lives of many house cats have come to a sudden end because of their appetites for chicks-and who wants to kill a pet cat? The cat is not to blame.

For a long time chicken-keepers have sought a simple, reli-

SANITARY HOVER

able, economical rat-proof brooder cage. This rat-proof cage meets every requirement, which means that it is as nearly perfect as any human invention can be. Material the best, plan the sanest and most humane. Eventually you will buy a cage. Why not now? Price $\$ 4.00$.

\section{THE TENT BROODER}

Hadn't thought of brooding chicks in a tent, had you?

Well, it's a crackerjack place to brood 'em. We've tried it and know.

No dark corners nor bright sunshiny spots for chicks to huddle in instead of going under the hover to warm up. Then there is plenty of fresh air, and a tent is easy to change to fresh ground. Also the cost of a tent and hover combined is less than that of a colony house of wood.

The brooder tent is 6 feet square and 6 feet high; is made of 8-oz. water-proof ducking, with

ventilator at rear upper corner; will

We are making special reductions this year on quantity lots of Incubators and Brooders.

Submit us a definite list of what you want and get our prices.

TENT BROODER

last many years if f old ed carefully and $\mathrm{put}$ away in a dry place after the brooding season is over.

These brooder tents are right up to the standard in all particulars.

Price, complete with poles and stakes. $\$ 6.00$ each.

We issue a complete circular about Feb: 15th each year covering all poultry supplies carried in stock by us. This list is more accurate than our catalogue and the prices revised. Write for copy.

RAT-PROOF CAGE

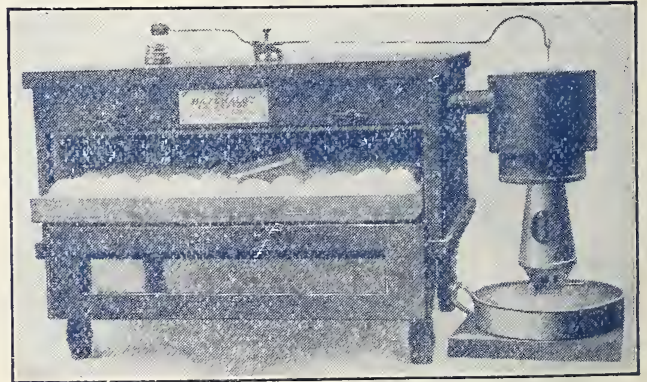

HATCHALOT INCUBATOR

60-EGG HATCHALOT INCUBATOR

This 60-egg Hatchalot Incubator is not only the best hatcher but the best incubator for the price on the market today. It is made of No. 1 Cypress; has a strong zinc and steel thermostat, in fact, is equipped with a complete, absolutely dependable regulating device. The boiler is large and is so constructed that it will heat the incubator under any ordinary climatic condition. Its mild heat prevents evaporation of the moisture, so that all eggs with chicks in them will hatch, and every chick will be as large as the egg shell will allow. This incubator is sold with a money-back guarantee. Price, $\$ 7.50$. 


\section{THE PLAIN TRUTH ABOUT SEED MCVAY SEED AND FLORAL COMPANY \\ BIR M I N G HAM, A LA BA MA}

\section{Buckeye Incubators}

THE STANDARD HOT WATER INGUBATORS OF THE WORLD

ON THE MARKET 22 YEARS. OVER 325,000 IN SUCGESSFUL OPERATION

Buckeye Incubators are equipped with every desirable device that can possibly add to incubator efficiency, and they are sold with an absolute guarantee to hatch a chick from every hatchable egg.

Buckeye Incubators are so simple that the beginner can operate them just as successfully as the experienced poultryman-that's why they are so uniformly satisfactory.

We have a Buckeye in operation most all the time. Come in and see the chicks hatching, and we can easily convince you that you can hatch more chicks and better chicks with a Buckeye than with the best old hen or incubator you ever owned.

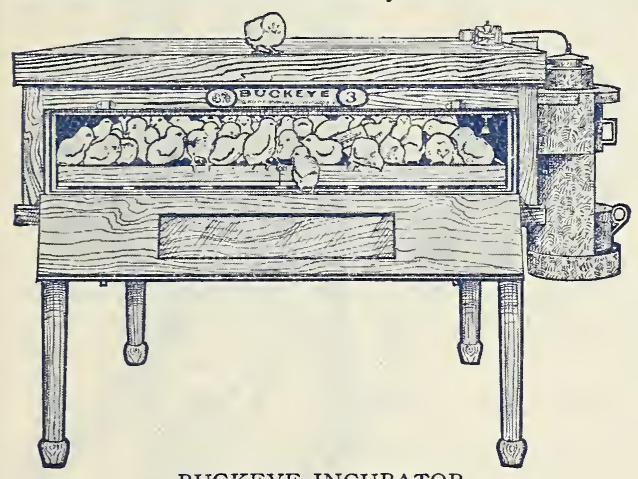

BUCKEYE INCUBATOR

BUCKEYE INGUBATOR

Style A

Capacity 60 Eggs

Complete, ready to use Ask for large illustrated catalogue of Buckeye Incubators.

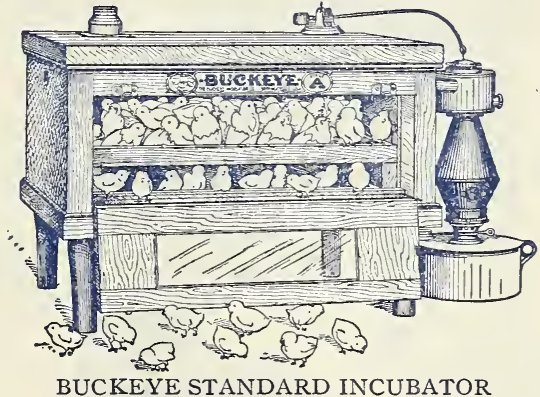

\section{BUCKEYE STANDARD INGUBATORS}

No. 1, Capacity 110 Eggs $\$ 18.00$

No. 2, Capacity 175 Eggs 23.00

No. 3, Capacity 250 Eggs 30.00 38.00

\section{Buckeye Brooders}

Buckeye Brooders are constructed on absolutely correct principles that provide those conditions which are so essential to the health and welfare of the growing chicks.

The heat supply comes from the top and the hover is kept uniformly warm at every point-that prevents crowding.

The temperature is regulated to a degree by a dependable thermostat - that prevents overheating and chilling.

The ventilating system provides for a constant circulation of pure, fresh, warm air-that prevents sickness and promotes that rapid growth of the chicks for which the Buckeye Brooder is famous. before.

Use Buckeye Brooders and you will raise more chicks and stronger chicks than you ever raised
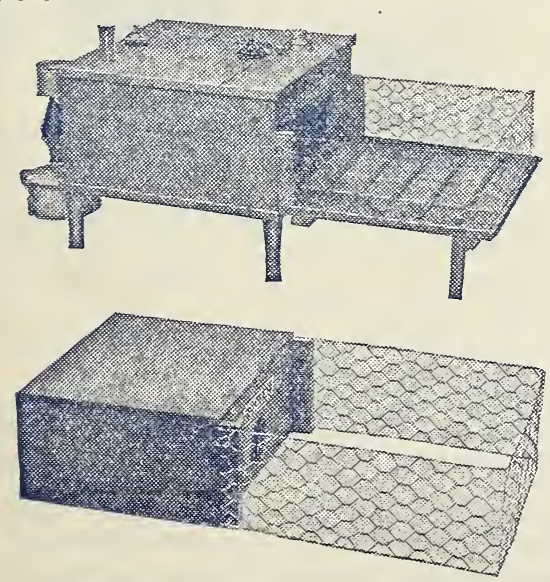

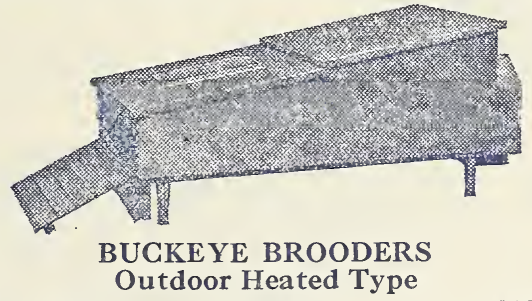

No. 2, Capacity 50 Chicks. $\$ 12.00$ 18.00

No. 4, Capacity 100 Chicks

\section{BUCKEYE BROODERS} Indoor Heater Type

No. 1, Capacity 50 Chicks. $\$ 8.00$

No. 3, Capacity 100 Chicks. 10.00

BUCKEYE BROODERS

Indoor Lampless Type

No. 5, Capacity 25 Chicks. $\$ 2.00$

No. 6, Capacity 50 Chicks. 3.00

Ask for a large illustrated catalogue of Buckeye Brooders. 


\section{Brandt Spray Pumps}

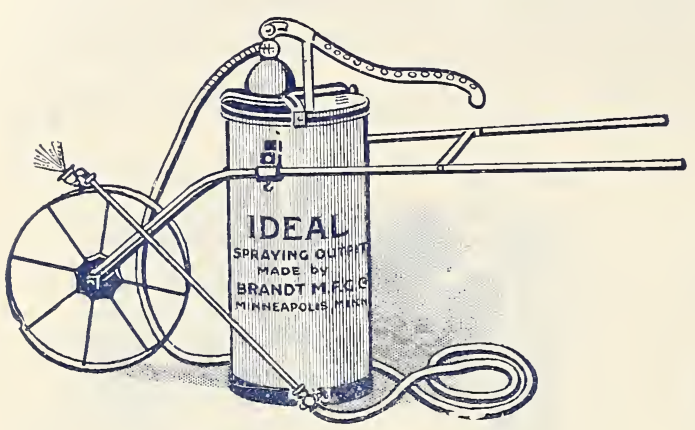

Fig. 12

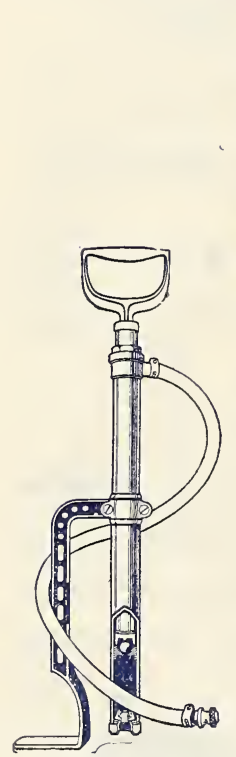

Fig. 14

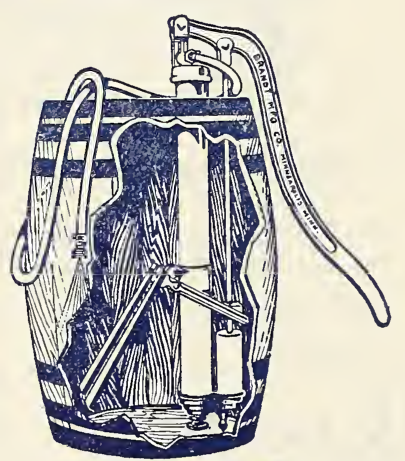

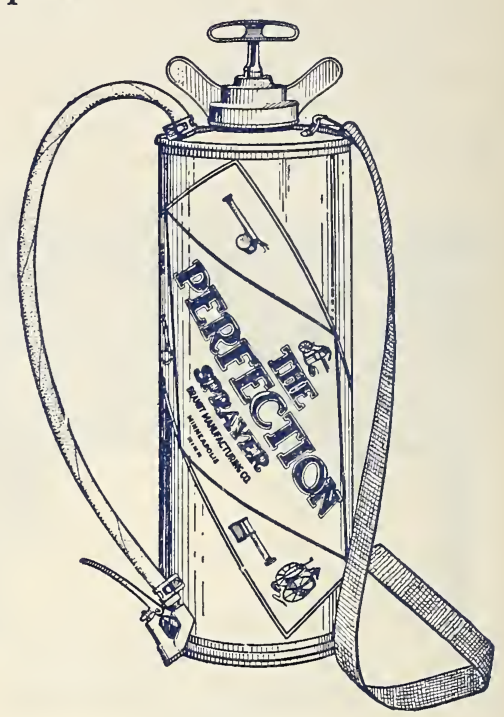

Fig. 40

Fig. 47

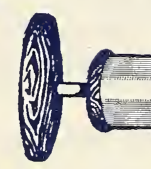

Fig. 50

We are agents for this line of Sprayers, which is so extensive that it is impossible to go into complete descriptions, but those interested should write us for a complete catalogue of the Brandt line. We list only the popular sorts. Write us for Brandt's Special Sprayer Catalogue.

Fig. 50-A small tin Sprayer, capacity about one quart, very desirable where a large amount of spraying is not needed. This is an excellent sprayer for spraying chicken houses. Price: Each, 50c.

Fig. 47-No. 6A "King" Pump, with one lead of 15 feet pressure hose, 8 feet of pipe, brass shutoff cock, nozzle, hose, clamps, etc. We do not furnish barrels. Price: $\$ 17.25$.

Fig. 14-The best bucket pump on the market. All parts are brass except the foot piece and handle. Price: Each, $\$ 4.00$.

Fig. 40-The "Perfection" Sprayer. Capacity 33/4 gallons. Tank 20 inches high, $71 / 2$ inches in diameter. Made in either galvanized or brass, complete with Automatic Perfection Shut-off Nozzle. This Sprayer will handle whitewash, water paints, Bordeaux mixtures, lime, sulphur and etc. Price: Galvanized steel, $\$ 5.00$; brass, $\$ 7.00$.

Fig. 12-"Ideal" Spray Outfit. This is one of the most popular sprayers on the market. Everybody who has any amount of spraying to do should have one of these. Price: Complete, $\$ 20.00$.

Look over our list of Sprayers, and if you don't see what you want, write us. Tell us your troubles about insects and let us help you. 


\section{Brown's Auto Sprays}

Capacity About 4 Gallons

The Auto-Spray No. 1 is the strongest and most simple in its parts of any compressed air sprayer. Each machine is tested before leaving the factory and guaranteed to be satisfactory. Will handle all solutions, including whitewash. Two, or at most three, pumpings will empty the tank and after pumping, the operator has only to direct the spray.

Tank-Either heavy brass or galvanized iron. Seams locked, soldered and riveted.

Pump-Seamless brass, $2^{\prime \prime}$ diameter. The pump is locked into the reservoir by means of a sliding cam which is drawn tight by the handle. No screw connection to wear on the gasket and become leaky. This locking device is simple and will give long service. All parts are instantly accessible.

Equipment-Two feet of $1 / 2^{\prime \prime}$ hose, fine spray nozzle, solid stream cap and either stop cock or our patented self-cleaning automatic shut-off as ordered. Full directions with repair list and spray calendar accompany each machine. Shipping weight, in wooden box, 15 lbs.

\section{NET CASH PRICES}

Auto-Spray No. 1-A, brass tank with stop cock. $\$ 6.75$

Auto-Spray No. 1-B, brass tank with auto-pop. 7.25

Auto-Spray No. 1-C, galv. tank with stop cock 4.50

Auto-Spray No. 1-D, galv. tank with auto-pop 5.00

$2^{\prime \prime}$ brass extension .45

Brass elbow.

Brass strainer.

Two-row attachment, brass.

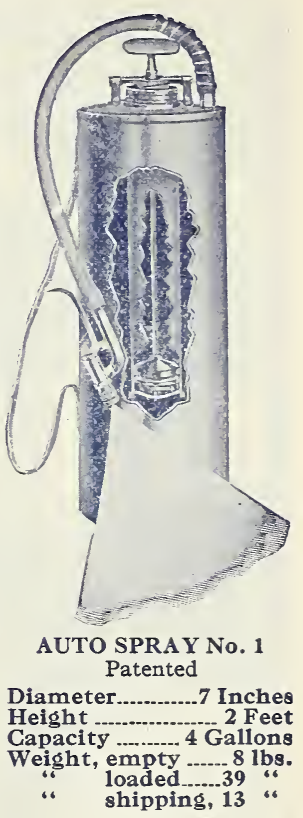

\section{The Auto Spray No. 37}

Continuous Sprayer. Capacity About One Quart Will Handle All Solutions

Removable front-permits syphon tube to be withdrawn for cleaning. Screw caps reinforced with thumb levers-easy to turn. Plunger rod $1 / 4^{\prime \prime}$ copper plated steel. Brass ball valve. Pump

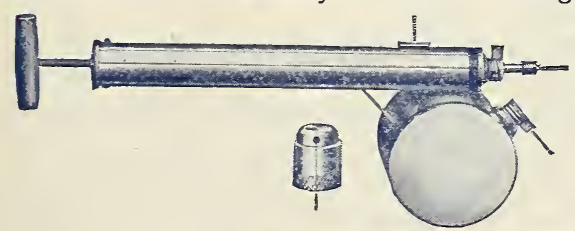

COMPRESSED AIR SPRAYER cylinder retinned at point where solution reaches, and is non-corrosive.

Two spray caps, one straight the other at an angle. Construction of tank permits the sprayer to be operated at any angle and will not tip over when filling.

\section{LIST PRICES}

Auto-Spray No. 37-A, all tin $\$ .80$ Auto-Spray No. 37-B, galvanized reservoir-.---.-.-----.-.. $\quad .90$ Auto-Spray No. 37-C, brass reservoir. 1.25

\section{Spray Solutions and Insecticides}

Those interested should refer to page 79 and if you don't see what you want, tell us your troubles, just what you want to destroy and we can help you. We generally have printed information on hansd but are always able to give you a formula by mail for any purpose and can supply the material. Everybody ought to have a good copper sprayer-it don't pay to buy any other. A great many States now have laws compelling the spraying of all fruit trees, where the fruit is to be marketed. The quality of the fruit and the increased yield through spraying is of incalculable value. 


\section{The Bowers and Franklin Cotton Seed Culler}

\section{The Greatest Invention for the Gotton Grower Since the Advent of the Cotton Gin}

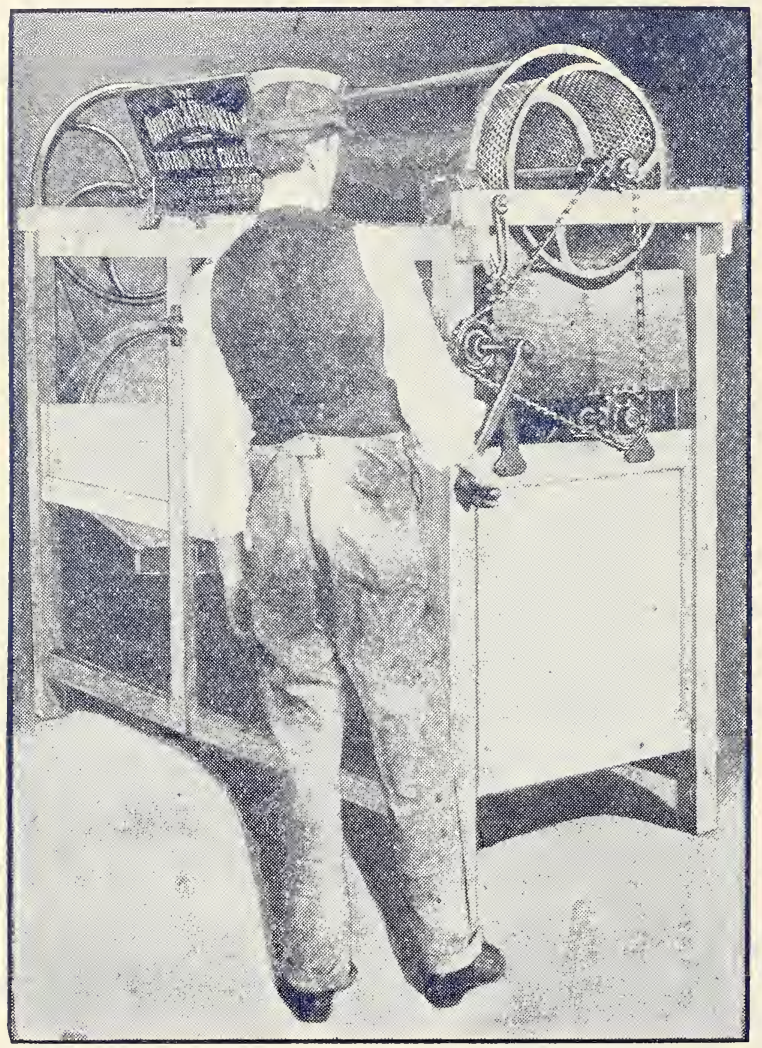

COT TON SEED CULLER
A money maker for Farmers, Ginners, Cotton Seed Oil Manufacturers and especially valuable for Cotton Seed Breeders.

The seed are feed into a hopper from which they pass to a cleaning screen, which removes from them all large trash, such as pieces of stalk, parts of bolls, locks of cotton, clods of dirt - everything which would interfere with the passage of the seed through a cotton planting machine.

From the cleaning screen the seed pass into the separating screens proper, which winnow the undersized cotton seed, and "slick" black seed, as well as all "motes" and grass and weed seed, insuring a cleaner crop; and, in their descent from the screens, the full-size seed pass through a current of air generated by a fan and sufficiently strong to blow back those which lack the required weight, the light seed falling into the base of the machine from which they are removed automatically and deposited at the end of machine opposite to that from which the perfect seed emerge.

In these few words, you have the description of a machine which has been brought to its present state of unqualified efficiency after a long series of experiments by men fully conversant with all conditions and factors of the problem to be solved.

Write us for catalogue and particulars on this famous cotton seed culler. We invite correspondence.

\section{Bug Death}

Bug Death-Is a powder, not poisonous to human life, but is certain death to all classes of leafeating insects. It is not recommended for insects which suck the sap, as these insects are in an en-

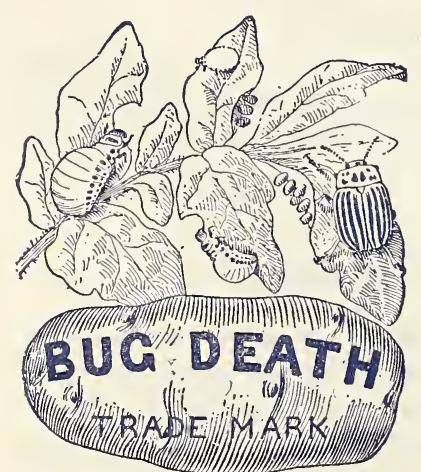

Pat. March 16 and Nov. 9, 1897 . tirely different class and require a different insecticide. Bug Death is also a fertilizer, so when you take into account this value, the powder seems very cheap. The usual method of applying it is to dust it lightly on the foliage. There is a specially constructed shaker for this purpose that we can supply at a cost of 25 cents. But it can be successfully applied by putting in a thin cloth sack, and shaking the sack over the plant, which will cause the powder to dust through the cloth.

Bug Death is just the sort of insecticide you need-it is safe, easily applied and a sure BUG KILLER.

Gardeners, farmers and everybody raising a garden should make it a point to order their Bug Death when ordering your seed. You most assuredly will have need for Bug Death for all gardeners have trouble with insects. So get busy and arm yourself with Bug Death. You can fight a whole army of bugs, with the aid of Bug Death. Price: Lb., 15c; 3-lb. pkg., 35c; 5-lb. pkg., 50c; 12-lb. box, $\$ 1.00 ; 100-1 b . ~ k e g$, \$7.50. Postpaid-Lb., 25c; 3-lb. pkg., 60c; 5-lb. pkg., 90c. 


\section{Insecticides, Bug Poisons}

Bug Poisons should be ordered when you send in an express or freight order for seed. They are too heavy for the mails, and some of them, on account of their poisonous nature, are refused the mails.

Arsenate of Lead-It is impossible in this catalogue to go fully into the merits of the products of the Grasselli Chemical Company's goods for spraying purposes, but we will mail free printed information to those interested; but a few remarks here won't be out of place. The Grasselli Company manufactures the best powdered Arsenate of Lead to be dusted on tender foliage. They also manufacture an Arsenate of Lead Paste most useful when used in a spray solution. Another important item they make, is the Grasselli Bordeaux Mixture Paste. Through this mixture the use of Bordeaux is made plain and simple as well as economical. Another valuable product of the same company is the Grasselli Bordeaux Lead Arsenate Mixture Paste, which combination makes a valuable spray where fungicide and insecticide combined is required.

Price: Arsenate of Lead Paste, 1 lb., 25c; Bordeaux Mixture Paste, 1 lb., 20c; Bordeaux Lead Arsenate Mixture Paste, $1 \mathrm{lb} ., 25 \mathrm{c}$. Write for special catalogue and prices when in the market for large quantities.

Grasselli Lime Sulphur Solution-Is used as an insecticide to control San Jose Scale, Oyster Shell Scale, and all sucking or scale insects. For this purpose it is used as a dilution of 1 gallon to 9 to 11 gallons of water and applied during the dormant season, either after the leaves drop in the fall or before the buds open in the spring. The spring application, just before the buds open, will control leaf blister mite, plant lice and peach leaf curl, in addition to the scale insects, and is usually considered advisable in well cared for orchards where the scale is already under control and where the entire orchard can be gone over in the spring.

The fall application is advisable where trees have not been previously sprayed and are badly infested with scale or where the size of the orchard together with climatic conditions, render spring spraying impracticable. Grasselli Lime Sulphur Solution is also used as a summer spray to control scab, leaf spot and similar fungous diseases on apples and pears; also to control scab and brown rot on peaches, plums and cherries. On apple and pear foliage, it should not be used stronger than $11 / 2$ gallons to 50 gallons of water. Some prefer $11 / 4$ gallons to 50 gallons of water. On plum and cherry foliage, it should not be used stronger than 3 quarts to 50 gallons of water, and on peaches $1 / 2$ gallon to 50 gallons of water.

Slug Shot-Is a powder, not poisonous to any extent to human life, but certain death to all classes of leaf-eating insects. It is applied by dusting on in the dry state, or it can be mixed in water and sprayed on. Slug-Shot, when dusted on vegetation, will keep off more or less insects that it does not kill. It is a valuable fertilizer. Price-Lb., 10c; 5 lbs., 40 c; 10 lbs., $75 \mathrm{c} ; 100 \mathrm{lbs}$., $\$ 6.00$.

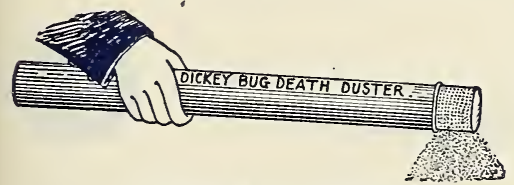

DICKEY BUG DUSTER

Dickey Bug Duster-A very simple little instrument for applying any form of bug poison in dry form. It will more than pay for itself in a day's using. Price, 25c.

Tobacco Dust-This is a most valuable insecticide and will drive away most all kinds of insects, being especially desirable to destroy lice and drive away bugs attacking melons, cantaloupe, squash, etc., Tobacco is a high grade fertilizer, and you can get your money back in plant food alone, to say nothing of the value as an insecticide. PriceLb., 5c; $10-1 \mathrm{~b}$. lots, $3 \frac{1}{2} \mathrm{c} ; 50-1 \mathrm{~b}$. lots, $3 \mathrm{c} ; 100-1 \mathrm{~b}$. lots, $21 / 2 \mathrm{c} ; 200-1 \mathrm{~b}$. bags, $2 \mathrm{c}$. Special prices in ton lots.

An Acre an Hour Duster-This is an improved sifter for applying all classes of dry poisons. Its construction is so regulated that you can apply any quantity for an acre. Price, each, 75c.

Paris Green-Is very poisonous. It is known to be the most reliable destroyer of all leaf-eating insects, but is almost worthless for destroying what is known as sucking insects. If thought desirable to use in solution, which is really the most economical way, from one-quarter to one pound will be sufficient to add to fifty gallons of water, the quantity depending upon the tenderness of the foliage it is to be applied to. Price of Paris Green, $1 / 4 \mathrm{lb} ., 10 \mathrm{c} ; 1 / 2 \mathrm{lb} ., 20 \mathrm{c}$; lb., 35 c; 5 to 10 -lb. lots, 30 c.

Sulpho-Tobacco Soap-For a cheap, effective, clean and harmless insecticide for amateur and professional growers, this is unexcelled. Quickly exterminates all insect life on plants and flowers in and out of doors. Unsurpassed for rose bushes. For domestic purposes it rids the house of cockroaches, and is a superior wash for dogs and all animals. Prevents poultry lice. A trial

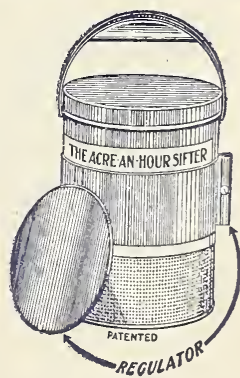

AN ACRE AN HOUR will give highly gratifying results. Three-ounce cake, sufficient for $11 / 2$ gallons prepared solution, $10 \mathrm{c}$; by mail, postpaid, 13c. Eight-ounce cake, sufficient for 4 gallons prepared solution, for 20c; by mail, postpaid, 28c. 


\section{Dr. A. C. Daniels' Warranted Dog and Cat Medicines}

These goods are, strictly guaranteed, and are highly recommended by all prominent Veterinary Doctors. We carry a full line of these goods. On account of the limited space, we request our patrons

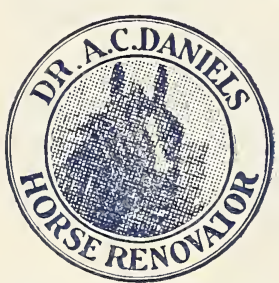
to write for special book on Horse and Cattle Remedies.

Dr. A. C. Daniels' Dog and Puppy Bread-A food for dogs. This bread is baked hard, will keep for months, is cheaper than meat, and far better, is medicated, and will keep your dog in the best of condition. All the leading dog shows of the East use this wonderful food, and we can also highly recommend it.

Dr. A. C. Daniels' Dog Soap-Is sure death to fleas, and will keep the coat in the very best of condition.

Dr. A. C. Daniels' Catnip Balls-The toy for cats

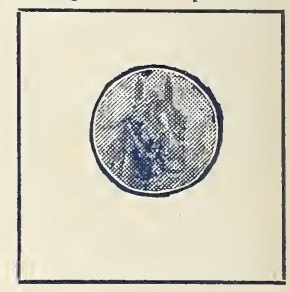
This is one of the greatest novelties ever put on the market, and is also a good exerciser for the cat.

Dr. Daniels issues a valuable DOG AND CAT BOOK, which we are pleased to give our customers. These books tell how to care and treat sick pets. They are free to our customers.

We feel that if you will give Dr. A. C. DANIELS' goods one trial you will never use any other, and remember they are strictly guaranteed. The following is only a partial list of the Dr. Daniels' remedies. Write us for complete book. We handle everything he makes.

Canker Remedy
Chorea \& Colic Remedy
Compound Sulphur Tablets
Distemper Tablets
Flea Powder
Laxative Tablets
Liver and Kidney Tablets
Mange Specific
Puppy Vermifuge
Restorative Tablets.

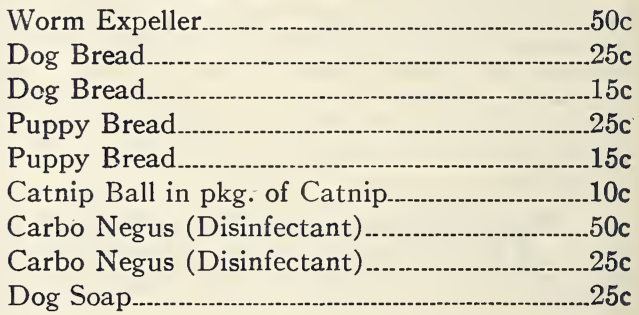

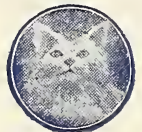

\section{Canary Birds and Supplies}

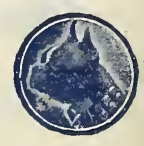

We carry a large stock of both male and female Canaries. We sell only the Hartz Mountainjand Saint Andersberg birds, which are all imported from Germany. And we guarantee every male_bird to be a singer.

Price of singer, $\$ 3.50$; female, $\$ 1.50$.

Supplies-Bird Cages, $75 \mathrm{c}$ to $\$ 7.00$.

Springs for cages, 10c each.

Mixed Bird Seed, specially prepared by us-10c pkg.; 3 for $25 \mathrm{c}$.

Plain Canary Seed, 10c per 1b.; German Rape Seed. 10c per lb.; Cuttle Fish Bone, 5c each.

WE ALSO CARRY A FULL LINE OF BIRD REMEDIES.

\section{Gold Fish and Supplies}

We always have a large stock of Gold Fish on hand and can supply you with any amount of them. Price, 10c up, according to size.

Fish Bowls or Aquariums, 20c up. Fish Food, 10c pkt. 


\section{McVay Seed \& Floral Company BIRMINGHAM, ALABAMA}

\section{PLEASE FILL IN THESE BLANKS PLAINLY}

Ship Articles on this Sheet as Specified.

Name

Postoffice

R. F. D. No.

County.

State.

\section{Amount Enclosed.}

Postoffice Order.

Stamps

Express Money Order.

Check

Date.

State Shipping Point if Different from Postoffice

\begin{tabular}{|c|}
\hline $\begin{array}{l}\text { HOW TO BE SENT } \\
\text { MAIL. }\end{array}$ \\
\hline $\begin{array}{l}\text { (By What Company) } \\
\text { EXPRESS }\end{array}$ \\
\hline $\begin{array}{l}\text { FREIGHT } \\
\text { (By What Railroad) }\end{array}$ \\
\hline
\end{tabular}

DON'T WRITE IN HERE

DATE REG'D

FILLED.

AMOUNT.

NO.

ABOUT DELIVERED PRICES-All small garden seed are delivered by us at prices in Catalogue, so when you order these with heavy stuff to come by express or freight deduct 10 cents per pound. Beans, peas, corn, farm seed and other heavy stuff require extra remittance for postage at the rate of 10 cents per pint or pound, and 15 cents per quart; that is, where no special price is quoted by mail postpaid.

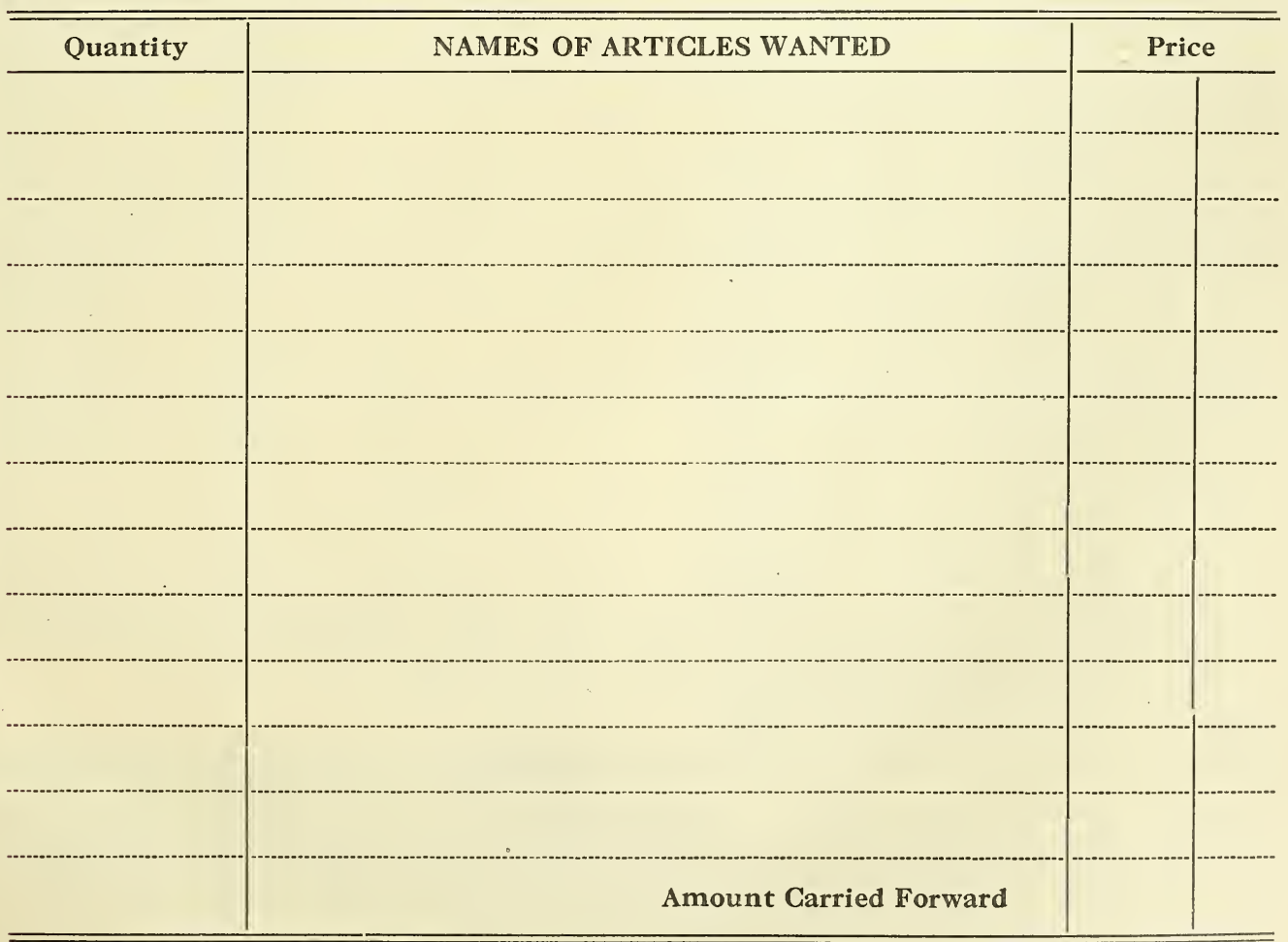




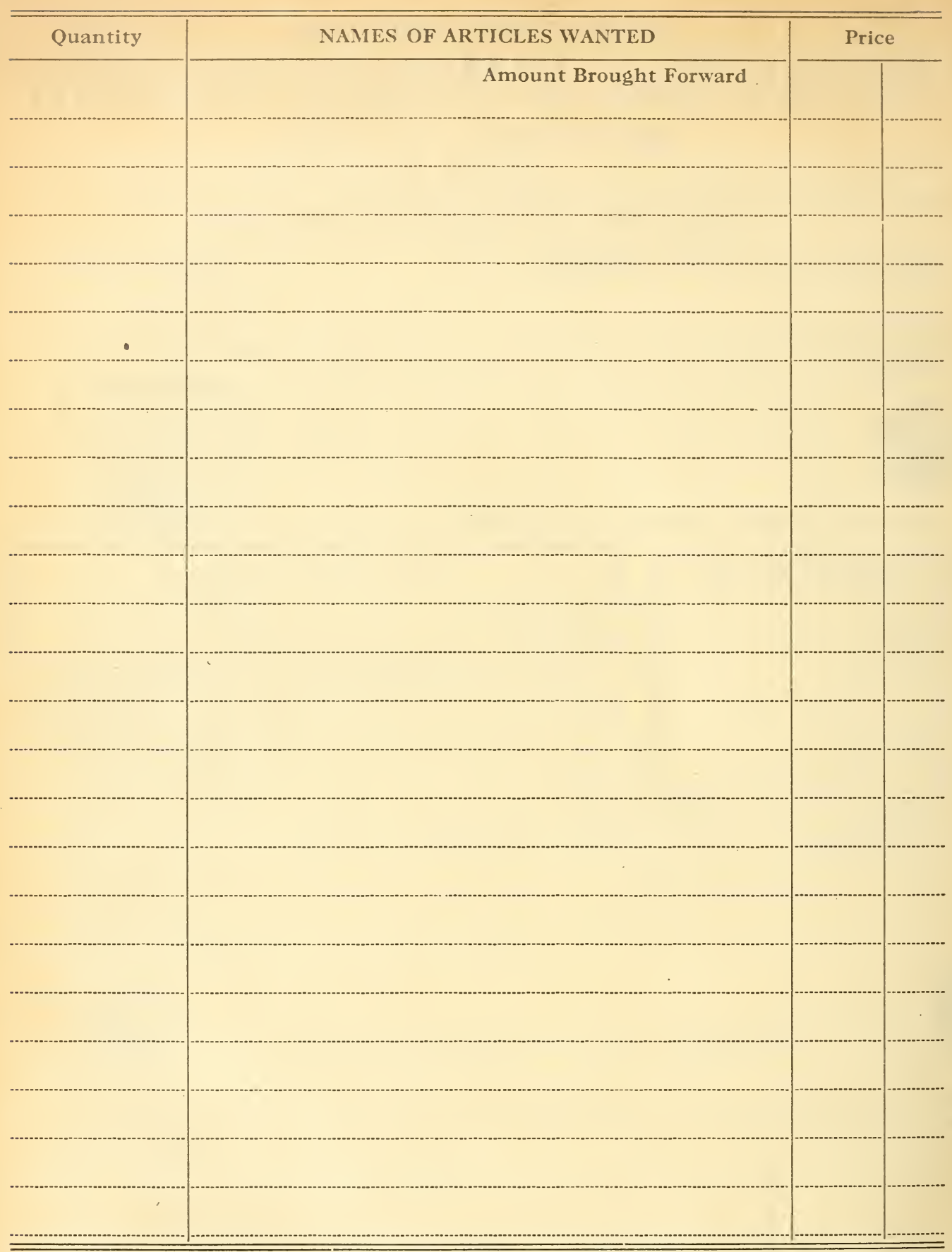

Write all you want to say about this order on this sheet. Requests for quotations and other information requiring an answer on separate piece of paper.

Send us here the name and address of two or three parties who plant a good lot of seed:

Name

P. O. Address

Name

P. O. Address

Name

P. O. Address

Messrs. McVay Seed \& Floral Co. gives no warranty, express'or implied, as to description, quality, productiveness, or any other matter of any Seeds, Bulbs or Plants they sell, and they will not be in any waK responsible for the crop. If the purchaser does not accept the goods on these terms they are at once to be returned, and money, if any that has been paid, will be refunded. 


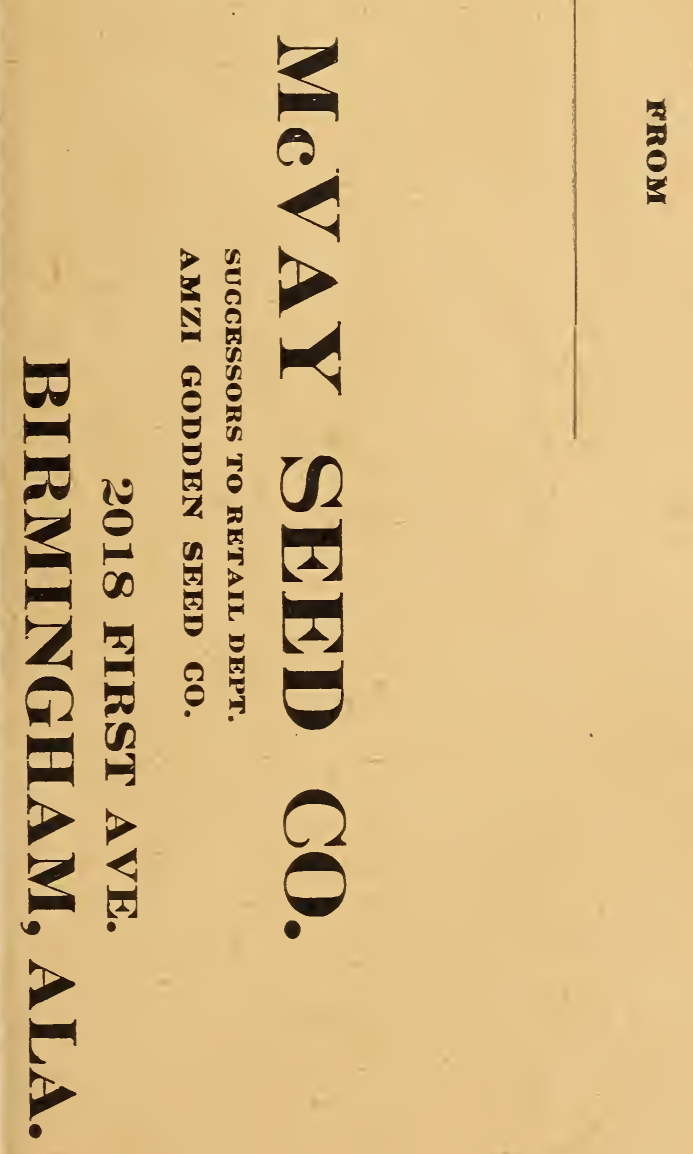





\section{FLORAL DEPARTMENT \\ OF MCVAY SEED \& FLORAL CO. Cut Flowers, Plants and Decorations
for all occasions}

We operate an up-to-date floral establishment and are prepared to make immediate deliveries of flowers, funeral designs and decorations to any city in the United States. Tnrough a chain of agents located in all important centers we are able to give you just as good service as we could for a Birmingham occasion. When you buy flowers from us you can confidently expect to get fresh stock and of the highest quality the market affords.

We employ the highest priced experts in the floral department, men and women who have graduated from the best establishments in the country. There is a touch and art about the work we turn out that is absent from amateurists' work. The secret of the whole thing is honest work, first class stock in the proper quantities, artistic arrangement and prompt and accurate service.

We make a specialty of weddings, fancy boquets for brides, bridesmaids, and the funeral work we turn out is in a class by itself.

\section{Potted Plants}

No one in the Birmingham market handles such an extensive line of potted plants as we. These include such staples as Ferns, Palms, Begonias, Geraniums, Rubber Plants, Cyclamens, Gloxinia, Azalias, Lilies, big assortment Bulbous Plants-in fact every sort of plant for the house or out door use.

\section{Bedding Plants}

We grow an immense line of plants of every description, including such staples as Alyssum, Ageratum, Asters, Carnations, Centaurea, Coleus, Daisies, Forgetme-not, Heliotrope, Hollyhock, Lantana, Larkspur, Mignonette, Nasturtium, Pansies, Pinks, Petunias, Salvia, Snap Dragon, Verbena, Moon Vines, etc. Our stock is well grown and the prices are correct.

\section{Spring Bulbs}

We have in season a large assortment of Spring and Summer Flowering Bulbs such as Caladiums, Tube Roses, Dahlias, Gladiolus, Cinnamon Vine, Maderia Vine, Sago Palms.

\section{Vegetable Plants, Shrubbery, etc.}

Our stock is always complete, in season and the quality of the stock we supply in the following cannot be surpassed.

Tomato Plants

Cabbage Plants

Lettuce Plants

Beet Plants
Celery Plants

Collard Plants

Sweet Potato Plants

Pepper Plants
Egg Plants, Etc. Asparagus Roots Rhubarb Roots

Strawberry Plants
Hydrangia

Rose Plants

Cape Jasmin

Dwarf Arborvita

\section{McVAY S \\ SEED \& FLORAL

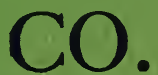

BIRMINGHAM, ALABAMA 


\section{The Jefferson County Savings Bank \\ BIRMINGHAM, ALABAMA}

CAPITAL AND SURPLUS $\$ 750,000.00$

RESOURCES $\$ 3,000,000.00$

NOW IN OUR

NEW HOME

OFFICERS

C. F. ENSLEN

Chairman

E. F. ENSLEN

President

C. E. THOMAS

Vice-Pres.

W. C. STERRETT

Cashier

W. D. ENSLEN

Ass't Cashier

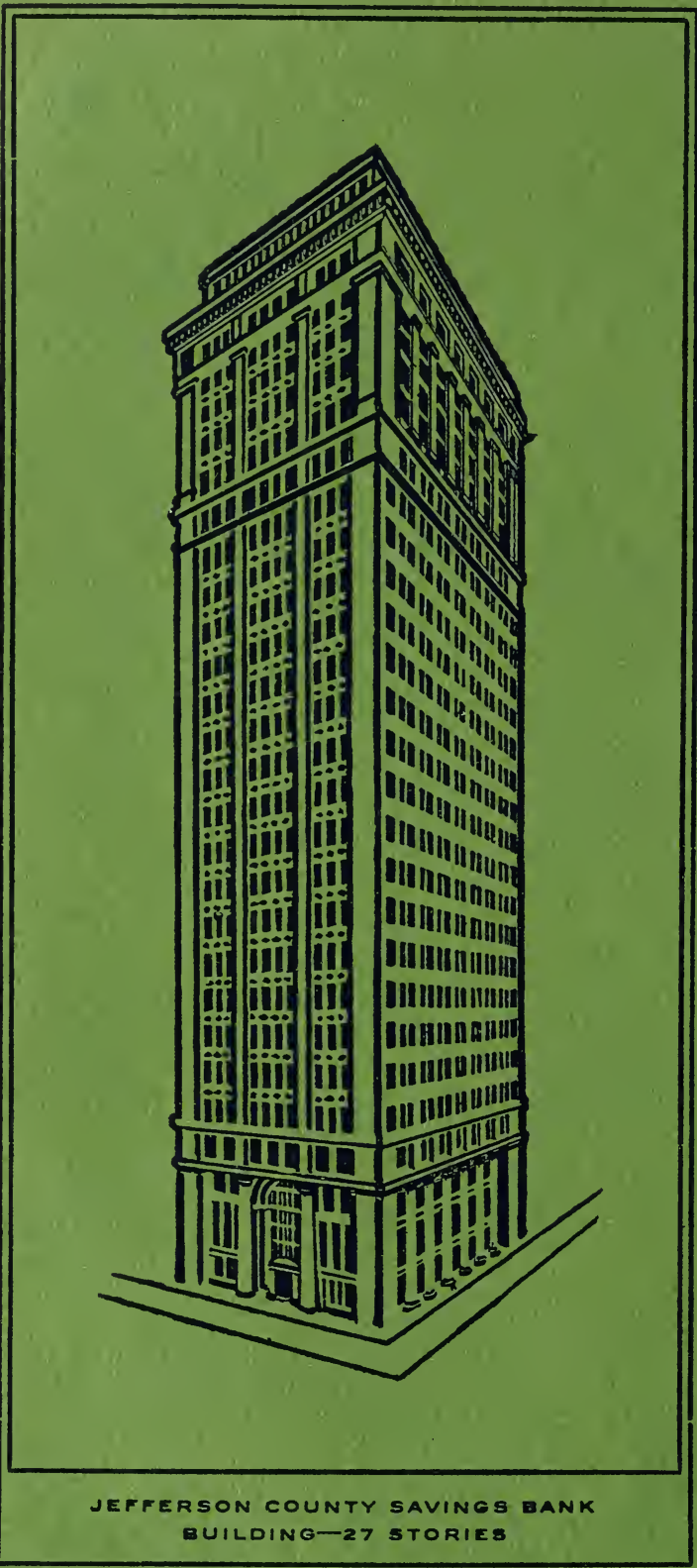

Accounts Invited on Favorable

Terms

$4 \%$ Interest

Paid on Savings

Deposits,

Compounded

Quarterly

Foreign Exchange

Bought and Sold

Commercial

Collection a

Specialty

"Banking by Mail" given special attention

Write us about starting an account 